\title{
TRATAMENTO ANAERÓBIO DE EFLUENTE CONTENDO PENTACLOROFENOL EM REATOR DE LEITO FLUIDIFICADO
}

Tese apresentada à Escola de Engenharia de São Carlos da Universidade de São Paulo, como parte dos requisitos para obtenção do título de Doutor em Hidráulica e Saneamento.

Orientador: Prof. Eduardo Cleto Pires

São Carlos

2005 
Ao meu irmão Fábio, que sempre será a inspiração para que eu seja uma pessoa melhor, à minha mãe Luzia, e meu pai Freire, por me mostrarem os caminhos,

e à Camila, que ilumina meu caminho, pelo amor de todo dia e pelo sorriso quente que me derrete!! 


\section{AGRADECIMENTOS}

Ao professor Eduardo Cleto Pires, ser humano dos mais nobres, pela amizade ao longo dessa parceria de 7 anos e pela liberdade concedida para que eu tomasse as atitudes necessárias, que me proporcionaram um aprendizado inestimável.

Ao meu pai, deixo um agradecimento especial que transcende o campo limitado das palavras, pois nem mesmo uma tese inteira seria suficiente para demonstrar a minha gratidão. Pela energia de um menino, sempre me provocando (no bom sentido) para que eu não perdesse o foco e a motivação, e pela humildade dos sábios, depois de tantos serviços prestados à ciência, estudar o PCP e os "bichinhos" comigo.

À Beth Moraes e Janja, pelo carinho e auxílio no dia-a-dia do LPB.

Ao professor Marcelo Zaiat, pelas sugestões na qualificação e pelas conversas, sempre produtivas.

Ao professor Artur de Jesus Motheo, pelas sugestões na qualificação e por fornecer a metodologia base para a realização das isotermas de adsorção.

À professora Mônica Lopes Aguiar, do DEQ - UFSCar pelo auxílio na análise de imagem das partículas.

À Luana Mareli, Andréa Buzzini e Cristina Yamamoto, pela amizade.

Aos amigos do Laboratório de Sistemas Particulados, em especial ao Roger, pelas fotografias, e aos gaúchos Marcos e Marcelo, pelas dicas sobre o "data logger".

À Flávia Talarico e ao Gunther, pelo auxílio com o PCP e ao Renato Siman, pela metodologia de avaliação da quantidade de biomassa aderida.

À Eloísa Pozzi, pelas sugestões na qualificação, pela orientação na preparação das amostras e pela realização das análises de microscopia óptica.

Ao professor Francisco Vecchia, pelas dicas sobre o registro de temperaturas.

Ao professor Edson Luís Silva, do DEQ / UFSCar, pela elaboração do plano inicial deste trabalho.

Ao Oscar da Silva, do DEQ / UFSCar, pela amizade e pela cooperação na construção dos reatores, na montagem do experimento, e na resolução de todos os "pepinos" com os equipamentos.

Ao Donizeti Luchesi, pela construção do reator para ensaios fluidodinâmicos.

A todo pessoal do LPB contemporâneo à minha estadia (de 2001 a 2005) que fez com que as horas no laboratório fossem sempre agradáveis, deixo um agradecimento coletivo para não cometer nenhuma injustiça.

À minha mãe, pela proteção e pelos doces saborosos, ao Fábio, pelas leituras e sugestões, mesmo à distância, e à Camila, por tudo.

À Fapesp, pelo financiamento da pesquisa e pela bolsa de doutorado. 
Não fosse isso

E era menos

Não fosse tanto

E era quase

(Paulo Leminski) 


\section{SUMÁRIO}

LISTA DE FIGURAS................................................................ i

LISTA DE TABELAS.............................................................

LISTA DE ABREVIATURAS E SIGLAS................................... xiii

LISTA DE SÍMBOLOS.............................................................. xiv

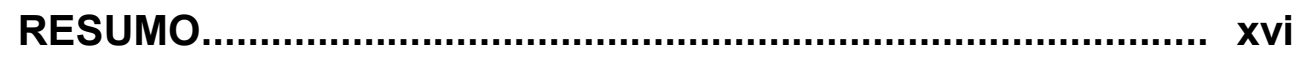

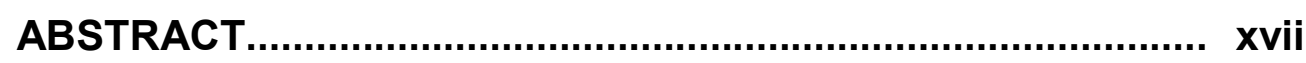

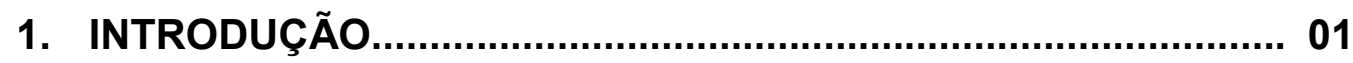

2. OBJETIVOS

3. REVISÃO DA LITERATURA................................................. 07

3.1 CONSIDERAÇÕES GERAIS …............................................. 07

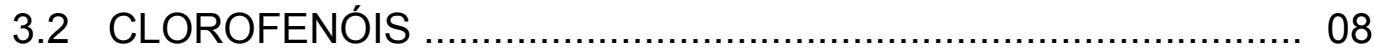

3.3 AS PESQUISAS DO LPB ENVOLVENDO TRATAMENTO ANAERÓBIO DE PCP.......................................................... 10

3.4 O LEITO FLUIDIFICADO NO TRATAMENTO ANAERÓBIO DE

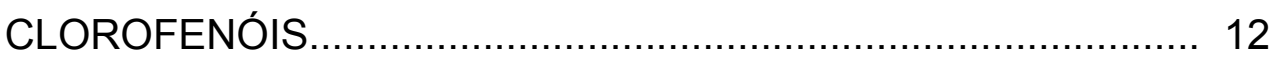

3.5 FLUIDODINÂMICA DE REATORES DE LEITO FLUIDIFICADO.. 30

3.6 CONSIDERAÇÕES FINAIS DA REVISÃO DA LITERATURA....... 48

4. MATERIAIS E MÉTODOS..................................................... 50

4.1 CONSIDERAÇÕES GERAIS.................................................. 50

4.2 MATERIAIS E PROCEDIMENTOS COMUNS A VÁRIAS

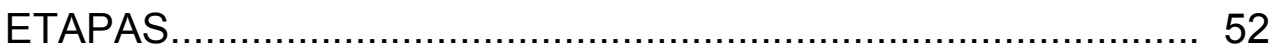

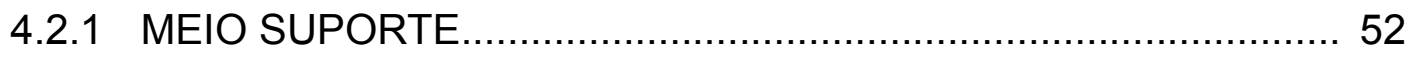

4.2.2 REATORES ANAERÓBIOS DE LEITO FLUIDIFICADO.............. 53

4.2.3 LODO DE INÓCULO............................................................... 55

4.2.4 SUBSTRATO SINTÉTICO ...................................................... 57

4.2.5 INOCULAÇÃO DOS REATORES.............................................. 59

4.3 AVALIAÇÃO DOS MATERIAIS SUPORTE................................ 60

4.3.1 CARACTERIZAÇÃO DAS PARTÍCULAS............................. 60

4.3.1.1 POROSIMETRIA DE MERCÚRIO_............................................. 61

4.3.1.2 ANÁLISE DE ADSORÇÃO FÍSICA (BET)................................. 61 
4.3.1.3 ANÁLISE DE IMAGEM.......................................................... 61

4.3.2 FLUIDODINÂMICA NO REATOR A .......................................... 62

4.3.3 POTENCIAL DE IMOBILIZAÇÃO DE BIOMASSA....................... 67

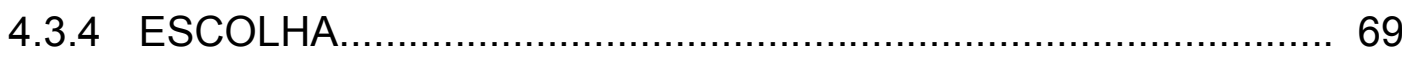

4.4 ESTUDO DAS INTERAÇÕES .................................................. 69

4.4.1 INTERAÇÕES ENTRE AS PARTÍCULAS INERTES E O

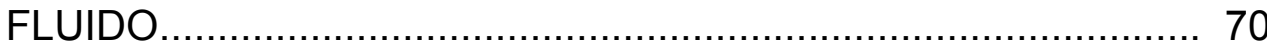

4.4.1.1 FLUIDODINÂMICA DO REATOR B COM PARTÍCULAS

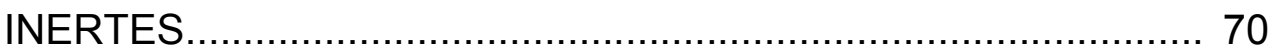

4.4.1.2 ISOTERMAS DE ADSORÇÃO COM PARTÍCULAS INERTES..... 72

4.4.2 INTERAÇÃO ENTRE AS BIOPARTÍCULAS E O FLUIDO............. 74

4.4.3 INTERAÇÃO ENTRE PARTÍCULA INERTE E FLUIDO................ 75

4.4.4 INTERAÇÃO ENTRE BIOPARTÍCULA E FLUIDO......................... 77

4.5 DESEMPENHO DO REATOR A SEM PCP................................. 78

4.5.1 PREPARAÇÃO DO LOCAL................................................. 78

4.5.2 PARÂMETROS OPERACIONAIS INICIAIS DO REATOR A ........ 80

4.5.3 PROGRAMAÇÃO DAS ANÁLISES......................................... 81

4.5.3.1 MICROSCOPIA ÓPTICA ….................................................. 83

4.5.3.2 MICROSCOPIA ELETRÔNICA DE VARREDURA (MEV)............ 84

4.6 DESEMPENHO DO RALF A COM O PCP............................... 85

4.6.1 PREPARAÇÃO DA SOLUÇÃO ESTOQUE DE PCP..................... 86

4.6.2 CONDIÇÕES OPERACIONAIS DO REATOR COM PCP............ 87

4.6.3 PROGRAMAÇÃO DAS ANÁLISES ........................................ 87

4.6.4 PRESERVAÇÃO DAS AMOSTRAS........................................ 87

4.6.5 ANÁLISE DA CONCENTRAÇÃO DE PCP................................ 88

4.6.5.1 PREPARAÇÃO DA AMOSTRA.............................................. 88

4.6.5.2 DESCRIÇÃO DA ANÁLISE..................................................... 89

4.6.5.3 DETERMINAÇÃO DA CONCENTRAÇÃO DE PCP..................... 90

4.6.6 CUIDADOS COM A SEGURANÇA ........................................... 91

4.6.7 CUIDADOS DURANTE A ROTINA EXPERIMENTAL.................. 91

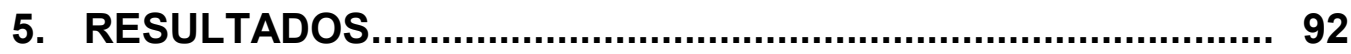

5.1 CONSIDERAÇÕES GERAIS ............................................... 92 
5.2 AVALIAÇÃO DAS PARTÍCULAS PARA ESCOLHA DO MELHOR MEIO SUPORTE................................................... 92

5.2.1 CARACTERIZAÇÃO DAS PARTÍCULAS.................................. 92

5.2.1.1 POROSIMETRIA DE MERCÚRIO E BET ..................................... 93

5.2.1.2 MICROSCOPIA ELETRÔNICA DE VARREDURA DAS PARTÍCULAS INERTES........................................................... 94

5.2.1.3 ANÁLISE DE IMAGEM........................................................... 95

5.2.2 FLUIDODINÂMICA NO REATOR A COM PARTÍCULAS

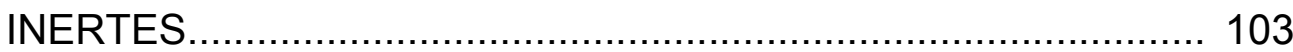

5.2.3 POTENCIAL DE IMOBILIZAÇÃO DE BIOMASSA...................... 109

5.2.4 DISCUSSÃO E ESCOLHA ..................................................... 111

5.3 ESTUDO DAS INTERAÇÕES................................................ 113

5.3.1 INTERAÇÕES ENTRE AS PARTÍCULAS INERTES E O

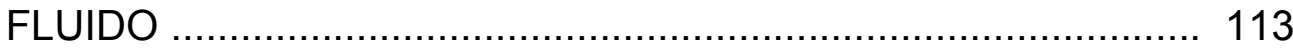

5.3.1.1 FLUIDODINÂMICA DO REATOR B COM PARTÍCULAS

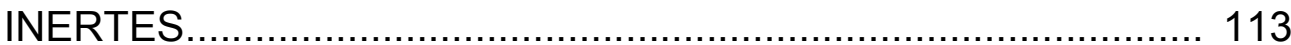

5.3.1.2 ISOTERMAS DE ADSORÇÃO COM PARTÍCULAS INERTES..... 118

5.3.2 INTERAÇÃO ENTRE AS BIOPARTÍCULAS E O FLUIDO............. 121

5.3.3 INTERAÇÃO ENTRE PARTÍCULA INERTE E FLUIDO................. 125

5.3.4 INTERAÇÃO ENTRE BIOPARTÍCULA E FLUIDO........................ 128

5.3.5 DISCUSSÃO GERAL SOBRE OS EFEITOS DA BIOMASSA NO COMPORTAMENTO DO LEITO............................................... 130

5.3.6 DIFICULDADES E PROBLEMAS OPERACIONAIS ENCONTRADOS

5.4 DESEMPENHO DO REATOR A (SEM A INTRODUÇÃO DO PCP)

5.4.1 DESCRIÇÃO DAS FASES OPERACIONAIS............................. 140

5.4.2 VARIAÇÃO DOS PARÂMETROS DE MONITORAMENTO DO RALF A.

5.4.3 DISCUSSÕES SOBRE A ETAPA DE OPERAÇÃO DO RALF A SEM O PCP E DIFICULDADES ENCONTRADAS 157

5.5 DESEMPENHO DO REATOR A COM PCP. 158 
5.5.1 DESCRIÇÃO DAS FASES OPERACIONAIS

158

5.5.2 MONITORAMENTO DA TEMPERATURA................................ 159

5.5.3 ANÁLISES DE MICROSCOPIA............................................... 164

5.5.4 VARIAÇÃO DOS PARÂMETROS DE MONITORAMENTO DO

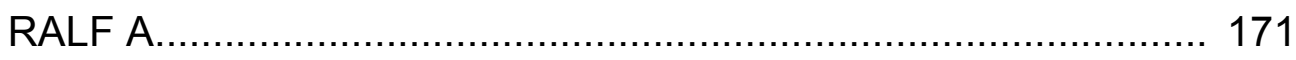

5.5.5 DISCUSSÃO DOS RESULTADOS.......................................... 180

6. CONCLUSÕES E SUGESTÕES............................................. 182 REFERÊNCIAS BIBLIOGRÁFICAS......................................... 185 


\section{LISTA DE FIGURAS}

Figura 3.1 - Anel aromático com as respectivas posições......................... 08

Figura 3.2 - Exemplos de clorofenóis................................................ 08

Figura 3.3 - Concentrações afluente e efluente de PCP-Na no RALF utilizado por Tsuno et al. (1996)...................................... 16

Figura 3.4 - Degradação do PCP-Na sem a adição de acetato em experimentos em batelada realizados por Tsuno et al. (1996)

Figura 3.5 - Degradação do PCP-Na com a adição de acetato em experimentos em batelada realizados por Tsuno et al. (1996)

Figura 3.6 - Qualidade do efluente do RALF após o pulso "extra" contendo $4 \mathrm{~L}$ de uma solução orgânica com $16 \mathrm{~g}$ de acetato, $8 \mathrm{~g}$ de fenol, e $16 \mathrm{~g}$ de 2-CP, em trabalho de Suidan et al. (1996).

Figura 3.7 - Eficiência de remoção de DQO e conversão para metano em dois reatores RALF submetidos a vazões diferentes a partir da fase IV (KHODADOUST et al., 1997).

Figura 3.8 - Transformação do PCP em outros clorofenóis durante a operação do RALF A (KHODADOUST et al., 1997).

Figura 3.9 - Transformação do PCP em outros clorofenóis durante a operação do RALF B (KHODADOUST et al., 1997).

Figura 3.10 - Primeiro caminho de degradação provável do PCP no RALF (KHODADOUST et al., 1997)

Figura 3.11 - Segundo caminho de degradação provável do PCP no RALF (KHODADOUST et al., 1997)

Figura 3.12 - Caminhos para a degradação do 2,4 - Diclorofenol iniciado pelo processo de desalogenação redutiva (ZHANG E WIEGEL, 1990)

Figura 3.13 - Transformação do PCP em outros clorofenóis durante a operação do RALF (WILSON et al., 1998). 
Figura 3.14 - Remoção de TCP e DQO durante a operação do RALF (VALLECILLO et al., 1999)

Figura 3.15 - Sistema experimental do reator de leito fluidificado utilizado por Briens et al. (1997a).

Figura 3.16 - " "holdup" da fase líquida para uma velocidade superficial de gás de $6 \mathrm{~cm} / \mathrm{s}$ em um reator de leito fluidificado trifásico, de acordo com três métodos diferentes (BRIENS et al., 1997a)

Figura 3.17 - Gradientes de pressão e densidade do leito em função da velocidade superficial do líquido em um reator de leito fluidificado trifásico (BRIENS et al., 1997a).

Figura 3.18 - Velocidade mínima de fluidificação em um reator de leito fluidificado bifásico líquido-sólido (BRIENS et al., 1997a)....

Figura 3.19 - RALF utilizado por Diez-Blanco et al. (1995) para experimentos fluidodinâmicos.

Figura 3.20 - Avaliação do crescimento do biofilme (em termos de concentração de sólidos voláteis) ao longo das fases operacionais, para os diferentes pontos de amostragem do RALF de Diez-Blanco et al. (1995)...

Figura 3.21 - Velocidades ascensionais em função da porosidade para diferentes cargas orgânicas no experimento de DiezBlanco et al. (1995).

Figura 3.22 - Velocidades ascensionais em função da porosidade, previstas para diferentes cargas orgânicas (teóricas) em equacionamento apresentado por Diez-Blanco et al. (1995). 45

Figura 4.1 - Esquema com todas as etapas da pesquisa.

Figura 4.2 - (a) reator anaeróbio de leito fluidificado $A$

(b) reator anaeróbio de leito fluidificado $B$

Figura 4.3 - Tipos morfológicos encontrados nos grânulos do lodo de inóculo. a) feixe de bacilos semelhantes a Methanosaeta sp.; b) aglomerado de cocos; c), d), e) e f) bacilos filamentosos e cocos 
Figura 4.4 - Sistema integrado para análise de imagens das partículas inertes.

Figura 4.5 - Sistema experimental utilizado para os ensaios fluidodinâmicos no reator $A$.

Figura 4.6 - Método gravimétrico para determinação das vazões aplicadas ao reator

Figura 4.7 - Aparato experimental do ensaio de imobilização de biomassa para avaliação dos materiais suporte. (1) Reator "elemento de volume" (2) Reservatório para substrato (3) Banho de Gelo, (4) Agitador Magnético, (5) Amostrador, (6) Trocador de Calor, (7) Bomba peristáltica.

Figura 4.8 - Reator "elemento de volume" utilizado nos ensaios de imobilização de biomassa para avaliação dos três materiais suporte. 68

Figura 4.9 - Medidor de vazão tipo orifício. 71

Figura 4.10 - Sistema experimental utilizado para os ensaios fluidodinâmicos no reator $B$

Figura 4.11 - Desenho esquemático do ensaio em coluna para determinação da velocidade terminal da partícula 76

Figura 4.12 - Cabine térmica para abrigar o sistema experimental.. 78

Figura 4.13 - Cabine térmica com refrator / isolamento térmico. 79

Figura 4.14 - Amostradores para os perfis do reator $A$.

Amostrador A: para coleta de biopartículas

Amostradores B, C, D e E: para coleta de amostras do

líquido ao longo da altura do reator.

Figura 4.15 - Termopar tipo "T" utilizado no monitoramento das temperaturas

Figura 4.16 - Central de registro de dados conectada ao microcomputador.

Figura 4.17 - Curvas de calibração para os compostos padronizados, na concentração de 0 a $5 \mathrm{mg} / \mathrm{L}$.

Figura 5.1 - Micrografia obtida via MEV da partícula de basalto 
Figura 5.2 - Micrografia obtida via MEV da partícula de alumina........... 94

Figura 5.3 - Micrografia obtida via MEV da partícula de carvão ativado.. 95

Figura 5.4 - Imagem registrada das partículas de alumina analisadas.... 96

Figura 5.5 - Partículas de alumina.............................................. 96

Figura 5.6 - Imagem registrada das partículas de basalto analisadas..... 98

Figura 5.7 - Imagem registrada das partículas de carvão ativado

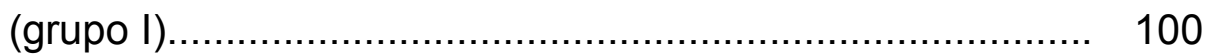

Figura 5.8 - Diferenças de pressão em função da velocidade para o reator $\mathrm{A}$, sem partículas.

Figura 5.9 - Curva característica para o reator A preenchido com três diferentes materiais suportes, com indicação das velocidades de mínima fluidificação. (•) alumina (匹 ) basalto ( $\boldsymbol{\Delta})$ carvão 105

Figura 5.10 - Expansão do leito do reator A preenchido com três diferentes materiais suporte. $(\bullet)$ alumina $(\square)$ basalto ( $\Delta$ ) carvão

Figura 5.11 - Porosidade do leito do reator A preenchido com três diferentes materiais suporte. $(\bullet)$ alumina $(\square)$ basalto ( $\Delta$ ) carvão. 108

Figura 5.12 - Resultado (em mgSTV / gSUP) do ensaio de imobilização de biomassa em reatores "elemento de volume" para três diferentes materiais suporte. $(\bullet)$ alumina $(\square)$ basalto ( $\Delta$ ) carvão. 109

Figura 5.13 - Resultado (em mgSTV / mLSUP) do ensaio de imobilização de biomassa em reatores "elemento de volume" para três diferentes materiais suporte.

$(\bullet)$ alumina ( $\square$ ) basalto $(\boldsymbol{\Lambda})$ carvão 110

Figura 5.14 - Diferenças de pressão em função da velocidade para o reator $B$ sem partículas 
Figura 5.15 - Curva característica para o reator B preenchido com dois grupos de partículas inertes de carvão ativado, com indicação da velocidade de mínima fluidificação. (• ) grupo I: partículas com diâmetro médio de 2,16 mm ( ) grupo II: partículas com diâmetro médio de 3,08 mm.

Figura 5.16 - Expansão do leito do reator B preenchido com dois grupos de partículas inertes de carvão ativado.

(• ) grupo I: partículas com diâmetro médio de 2,16 mm

(घ ) grupo II: partículas com diâmetro médio de 3,08 mm....

Figura 5.17 - Porosidade do leito do reator B preenchido com dois grupos de partículas inertes de carvão ativado.

(• ) grupo I: partículas com diâmetro médio de 2,16 mm

(匹 ) grupo II: partículas com diâmetro médio de 3,08 mm....

Figura 5.18 - Isotermas de adsorção de Freundlich e Langmuir obtidas para a adsorção da solução 1 em carvão ativado. (-) Freundlich (-) Langmuir (•) dados experimentais.

Figura 5.19 - Isotermas de adsorção de Freundlich e Langmuir obtidas para a adsorção da solução 2 em carvão ativado.

(-) Freundlich (-) Langmuir (•) dados experimentais 120

Figura 5.20 - Isotermas de adsorção de Langmuir obtidas para a adsorção da solução 1 e da solução 2 em carvão ativado.

(-) solução 1 (•) solução 2 .

Figura 5.21 - Curva característica para o reator B preenchido com biopartículas

Figura 5.22 - Expansão do leito do reator B preenchido com biopartículas

Figura 5.23 - Porosidade do leito do reator B preenchido com biopartículas

Figura 5.24 - Velocidades terminais obtidas para as 50 partículas inertes de carvão ativado. $(\bullet)$ valor de cada partícula

(घ) valor médio. 
Figura 5.25 - Gráfico com a equação de Richardson \& Zaki linearizada, para determinação da constante empírica $\mathrm{n}$, através de valores experimentais de velocidade terminal, para partículas inertes com diâmetro de $3,08 \mathrm{~mm}$

Figura 5.26 - Velocidades terminais obtidas para as 50 biopartículas de carvão ativado. $(\bullet)$ valor de cada partícula

(घ) valor médio

Figura 5.27 - Gráfico com a equação de Richardson \& Zaki linearizada, para determinação da constante empírica $n$, através de valores experimentais de velocidade terminal.

Figura 5.28 - Curva característica para o reator B preenchido com partículas de carvão ativado de 3,08 mm de diâmetro, com indicação da velocidade de mínima fluidificação.

(• ) biopartículas ( $\bullet$ )partículas inertes.

Figura 5.29 - Expansão do leito para o reator B preenchido com partículas de carvão ativado de 3,08 mm de diâmetro

(• ) biopartículas ( $\square$ )partículas inertes.

Figura 5.30 - Velocidades terminais e respectivas médias obtidas para as biopartículas e partículas inertes, com diâmetro de $3,08 \mathrm{~mm}$.

Figura 5.31 - Variação temporal da concentração do substrato expressa como DQO para as 5 fases do RALF tratando substrato sintético. (•) DQO afluente (o) DQO efluente.

Figura 5.32 - Variação temporal da eficiência de remoção de DQO no RALF A tratando substrato sintético

Figura 5.33 - Reator B apresentando imobilização de biomassa nas paredes

Figura 5.34 - Variação temporal da concentração de alcalinidade total $\left(A_{T}\right)$ do RALF A tratando substrato sintético. $(\bullet) A_{T}$ afluente e (o) $A_{T}$ efluente.

Figura 5.35 - Variação temporal dos valores de pH no RALF A tratando substrato sintético. (•) pH afluente (o) $\mathrm{pH}$ efluente. 
Figura 5.36 - Variação temporal da concentração de AVT $\left(\mathrm{C}_{\mathrm{AVT}}\right)$ do RALF tratando substrato sintético para os primeiros 26 dias de operação. (•) $C_{A V t}$ afluente e (o) $C_{A V T}$ efluente......

Figura 5.37 - Variação temporal da concentração de AVT $\left(C_{A V T}\right)$ do RALF A tratando substrato sintético para os outros dias de operação (do dia 26 ao dia 105). (•) $C_{A V T}$ afluente e (o) $\mathrm{C}_{\text {AVT }}$ efluente

Figura 5.38 - Variação temporal da concentração afluente de cada ácido volátil do RALF tratando substrato sintético para os outros dias de operação (do dia 26 ao dia 105). (•) ácido acético e (•) ácido propiônico

Figura 5.39 - Bomba de recirculação colocada para fora da cabine antes da introdução do PCP no reator A

Figura 5.40 - Valores obtidos no monitoramento das temperaturas para um dia típico com grande variação de temperatura.

$(\bullet)$ temperatura externa $(\bullet)$ temperatura interna

(•) temperatura no líquido dentro do reator. 160

Figura 5.41 - Valores obtidos no monitoramento das temperaturas para um dia quente. $(\bullet)$ temperatura externa $(\bullet)$ temperatura interna $(\bullet)$ temperatura no líquido dentro do reator.

Figura 5.42 - Valores obtidos no monitoramento das temperaturas para um dia frio. $(\bullet)$ temperatura externa $(\bullet)$ temperatura interna $(\bullet)$ temperatura no líquido dentro do reator.

Figura 5.43 - Valores obtidos no monitoramento das temperaturas para o reator A operando como leito fixo. (•) temperatura externa $(\bullet)$ temperatura interna $(\bullet)$ temperatura no líquido dentro do reator.

Figura 5.44 - Fotomicrografias realizadas nas amostras de biopartículas coletadas no 30 o dia de operação do reator A sem PCP. (a), (b), (c) células semelhantes a bacilos não fluorescentes $(d)$ células semelhantes a cocos e bacilos não fluorescentes; (e) e (f) células semelhantes a bacilos e bactérias filamentosas não fluorescentes 
Figura 5.45 - Fotomicrografias realizadas nas amostras de biopartículas coletadas no 1050 dia de operação do reator A sem PCP.

(a) arranjo de células semelhantes a bacilos não fluorescentes (b) células semelhantes a bacilos não fluorescentes, com inclusões (c) células semelhantes a cocos não fluorescentes $(\mathrm{d})$ células semelhantes a methanosarcina sp (e) células semelhantes a methanosarcina $\mathrm{sp}$ analisadas sob fluorescência (f) células semelhantes a bacilos analisados sob fluorescência.

Figura 5.46 - Fotomicrografias (MEV) realizadas nas amostras de biopartículas coletadas no 1050 dia de operação do reator A sem PCP. (a), (b), (c) e (d) células semelhantes a bacilos

Figura 5.47 - Fotomicrografias realizadas nas amostras de biopartículas coletadas no 80 o dia de operação do reator A com PCP. (a) e (b) células semelhantes a bacilos não fluorescentes e bactérias filamentosas (c) e (d) células semelhantes a bacilos e cocos não fluorescentes (e) células semelhantes a methanosarcina $\mathrm{sp}(\mathrm{f})$ células semelhantes a methanosarcina sp analisadas sob fluorescência

Figura 5.48 - Fotomicrografias (MEV) realizadas nas amostras de biopartículas coletadas no 1050 dia de operação do reator A sem PCP. (a), (b), (c) e (d) células semelhantes a bacilos

Figura 5.49 - Variação temporal da concentração de substrato expressa como DQO no RALF A tratando substrato sintético com PCP. (•) DQO afluente (o) DQO efluente.

Figura 5.50 - Variação temporal da eficiência de remoção de DQO no RALF A tratando substrato sintético com PCP.

Figura 5.51 - Variação temporal da concentração de alcalinidade total $\left(\mathrm{A}_{T}\right)$ do RALF A tratando substrato sintético com PCP.

$(\bullet) A_{T}$ afluente e (o) $A_{T}$ efluente 
Figura 5.52 - Variação temporal dos valores de pH no RALF A tratando substrato sintético com PCP. (•) pH afluente

(o) $\mathrm{pH}$ efluente.

Figura 5.53 - Variação temporal da concentração afluente de ácidos voláteis no RALF A tratando substrato sintético com PCP... 174

Figura 5.54 - Variação temporal da concentração afluente de cada ácido volátil do RALF tratando substrato sintético com PCP. (•) ácido acético e $(\bullet)$ ácido propiônico $(\bullet)$ ácido butírico.

Figura 5.55 - Variação temporal da concentração de PCP $\left(\mathrm{C}_{\mathrm{PCP}}\right)$ no RALF A. (•) $C_{P C P}$ afluente (o) $C_{P C P}$ efluente.

Figura 5.56 - Variação temporal da eficiência de remoção de PCP no RALF A.

Figura 5.57 - Variação temporal da concentração de clorofenóis intermediários no efluente do RALF A. (•) TCP efluente $(\Delta)$ DCP efluente 


\section{LISTA DE TABELAS}

Tabela 3.1 - Resumo de algumas das pesquisas conduzidas no LPB relacionadas com o tratamento anaeróbio de PCP

Tabela 3.2resumo de trabalhos envolvendo reatores RALF no tratamento de substâncias tóxicas.

Tabela 3.3 - Fases e parâmetros operacionais de um RALF tratando fenol e 2 - CP, em trabalho de Suidan et al. (1996).

Tabela 3.4 - Fases e parâmetros operacionais de um RALF tratando PCP (KHODADOUST et al., 1997)

Tabela 3.5 - Fases e parâmetros de operação de um RALF tratando PCP (WILSON et al., 1998)

Tabela $3.6-$

Resumo da literatura de velocidade de mínima fluidificação

Tabela 3.7 - Fases e parâmetros de operação do RALF utilizado por Diez-Blanco et al. (1995).

Tabela 4.1 -

Composição da água residuária sintética. 57

Tabela 4.2 Análises realizadas e freqüência mínima. 81

Tabela $4.3-$

Parâmetros físico-químicos que foram monitorados 82

Tabela 4.4 Tempos de retenção para os clorofenóis padronizados.... 89

Tabela $5.1-$ Propriedades obtidas para os três materiais em análises de porosimetria de mercúrio e BET

Tabela $5.2-$ Partículas utilizadas na análise de imagem, seus diâmetros e metodologia de seleção desses diâmetros.... 96

Tabela $5.3-$ Análise do software Image Pro Plus para o diâmetro máximo, mínimo e médio de cada partícula de alumina analisada.

Tabela 5.4 - $\quad$ Análise do software Image Pro Plus para o diâmetro máximo, mínimo e médio de cada partícula de basalto analisada.

Tabela $5.5-$ Análise do software Image Pro Plus para o diâmetro máximo, mínimo e médio de cada partícula do grupo I (carvão ativado). 
Tabela 5.6 - Análise do software Image Pro Plus para o diâmetro máximo, mínimo e médio de cada partícula do grupo II (carvão ativado).

Tabela 5.7 - Partículas utilizadas nos ensaios de fluidodinâmica no reator $\mathrm{A}$, seus diâmetros e metodologia de seleção desses diâmetros.

Tabela 5.8 - Partículas de carvão utilizadas nos ensaios de fluidodinâmica no reator $B$, seus diâmetros e metodologia de seleção desses diâmetros.

Tabela 5.9 - Informações e parâmetros operacionais do RALF B no momento dos ensaios fluidodinâmicos com biopartículas. 122

Tabela 5.10 - Velocidades terminais das partículas inertes de carvão ativado obtidas em ensaio de coluna.

Tabela 5.11 - Velocidades terminais das biopartículas de carvão ativado obtidas em ensaio de coluna

Tabela 5.12 - Fases e parâmetros operacionais do RALF A utilizado na pesquisa, sem a adição de PCP

Tabela 5.13 - Parâmetros estatísticos obtidos para as concentrações de DQO (afluente e efluente) nas 5 fases.

Tabela 5.14 - Parâmetros estatísticos obtidos para as eficiências de remoção de DQO nas 5 fases

Tabela 5.15 - Parâmetros estatísticos obtidos para a alcalinidade total (afluente e efluente) nas 5 fases.

Tabela 5.16 - Parâmetros estatísticos obtidos para o pH (afluente e efluente) nas 5 fases

Tabela 5.17 - Parâmetros estatísticos obtidos para a concentração de ácidos voláteis (afluente e efluente) em cada uma das fases.

Tabela 5.18 - Informações e parâmetros operacionais do RALF A no momento da introdução do PCP

Tabela 5.19_ Fases operacionais e suas respectivas concentrações de PCP aplicadas ao RALF A utilizado na pesquisa 
Tabela 5.20 -. Parâmetros estatísticos obtidos para as concentrações de DQO (afluente e efluente) nas 5 fases................. 177

Tabela 5.21 - Parâmetros estatísticos obtidos para as eficiências de remoção de PCP nas 4 fases. 


\section{LISTA DE ABREVIATURAS E SIGLAS}

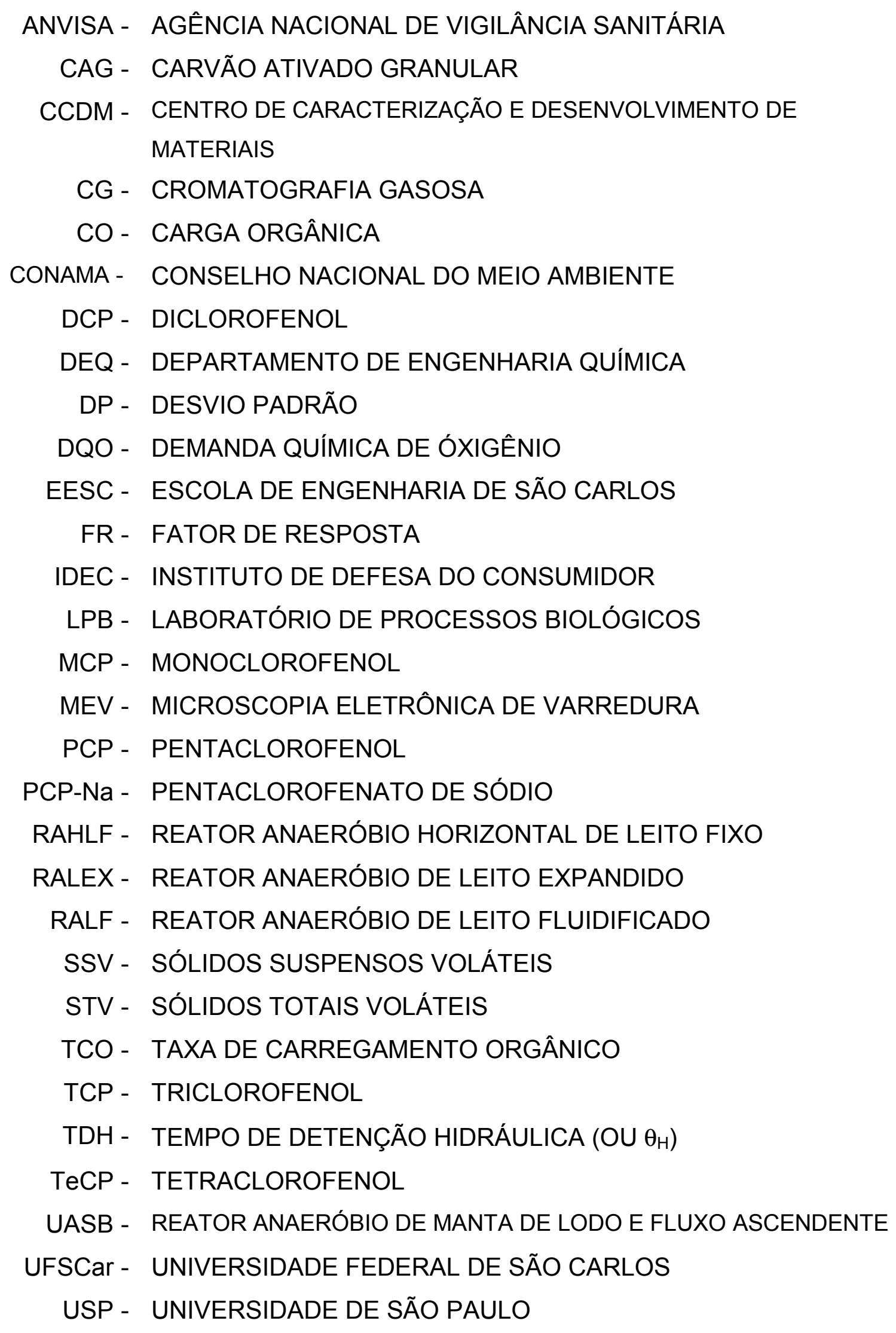




\section{LISTA DE SÍMBOLOS}

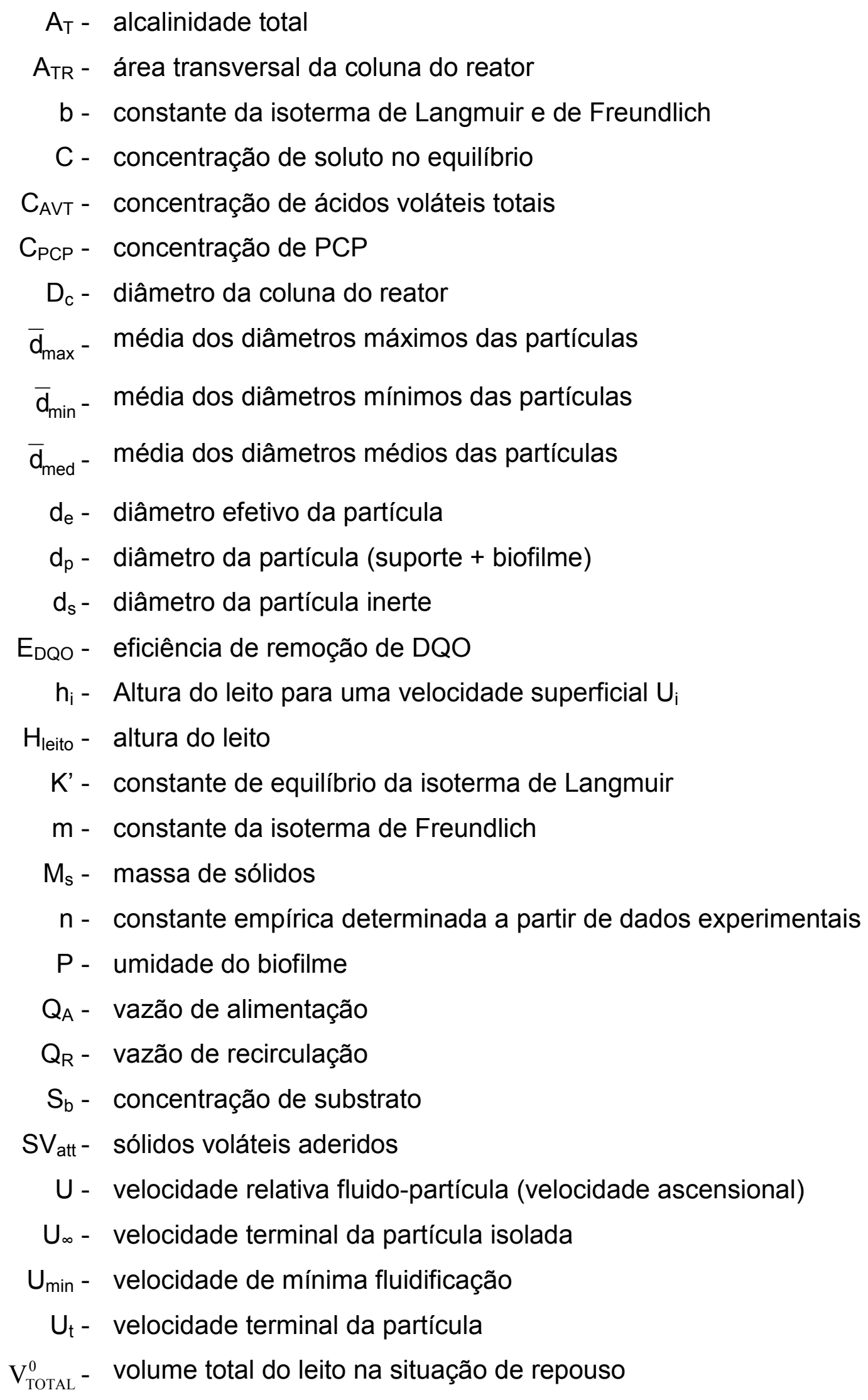


$\mathrm{V}_{\mathrm{LIQ}}^{0}{ }^{-} \quad$ volume de líquido correspondente a altura do leito em repouso

$\mathrm{V}_{\mathrm{TOTAL}}^{\mathrm{i}}$ - volume total (líquido + sólido) correspondente a uma determinada altura do leito $\left(\mathrm{h}_{\mathrm{i}}\right)$

$\mathrm{V}_{\mathrm{LIQ}^{\mathrm{i}}}^{\mathrm{i}}$ - volume de líquido correspondente à altura do leito $h_{\mathrm{i}}$

$\mathrm{V}_{\mathrm{TOTAL}}^{0}$ - volume total do leito na situação de repouso

$\mathrm{V}_{\mathrm{LIQ}^{-}}^{0}$ volume de líquido correspondente a altura do leito em repouso

$\mathrm{V}_{\mathrm{TOTAL}}^{\mathrm{i}}$ - volume total (líquido + sólido) correspondente a uma determinada altura do leito $\left(\mathrm{h}_{\mathrm{i}}\right)$

$\mathrm{V}_{\mathrm{LIQ}}^{\mathrm{i}}$ - volume de líquido correspondente à altura do leito $h_{i}$

$V_{S}$ - volume de sólidos

W - quantidade adsorvida por massa de adsorvente

$\Delta \mathrm{P}_{\mathrm{FLUID}}$ - diferença de pressão da fluidificação do leito

$\Delta \mathrm{P}_{\text {TOTAL }}$ - diferença de pressão total

$\Delta \mathrm{P}_{\mathrm{VAZIO}}$ - diferença de pressão do leito vazio

$\theta_{c}$ - tempo de retenção celular

$\delta$ - espessura do biofilme

$\varepsilon$ - porosidade do leito

$\varepsilon_{G}$ - "holdup" da fase gasosa

$\varepsilon_{\mathrm{L}}$ - "holdup" da fase líquida

$\varepsilon_{\mathrm{mf}}$ - porosidade nas condições de fluidificação

$\varepsilon_{\mathrm{mf}}$ - porosidade nas condições de fluidificação

$\varepsilon_{S}$ - "holdup" da fase sólida

$\rho_{\mathrm{bw}}$ - densidade do biofilme "molhado"

$\rho_{L}$ - densidade do líquido

$\rho_{\text {leito }}$ - densidade do leito

$\rho_{p}$ - densidade da partícula (suporte + biofilme)

$\rho_{s}$ - densidade da partícula inerte 


\section{RESUMO}

FREIRE, F.B. (2005). Tratamento anaeróbio de efluente contendo pentaclorofenol em reator de leito fluidificado. Tese (doutorado) - Escola de Engenharia de São Carlos, Universidade de São Paulo, São Carlos, 2005.

Remoções quase totais de clorofenóis, por processos anaeróbios, já foram atingidas mediante elevada concentração de matéria orgânica e um número considerável de fontes de carbono. Porém, é necessário que se investigue o desempenho dos reatores submetidos a condições menos idealizadas. Este trabalho apresenta o desenvolvimento de uma metodologia para avaliar um reator anaeróbio de leito fluidificado (RALF) como etapa de pré-tratamento de substrato sintético contendo pentaclorofenol (PCP). Para isso, foram adotadas as seguintes condições experimentais: fonte única de carbono; concentração reduzida de matéria orgânica; biomassa não previamente adaptada, e menores tempos de detenção hidráulica. Para cumprir o objetivo citado, foram desenvolvidos dois reatores, com 2,2 e 16 litros, respectivamente, e foram realizadas etapas de avaliação de materiais suporte, estudo de diversas interações (partícula / fluido, partículas fluido, biopartícula / fluido e biopartículas / fluido), e análise do desempenho do RALF sem PCP e com PCP. Os materiais suporte escolhidos foram a alumina, o basalto e o carvão ativado granular, todos com diâmetros próximos a $3 \mathrm{~mm}$. Eles foram avaliados em ensaios de caracterização física, de microscopia eletrônica de varredura, de fluidodinâmica e de análise de imagens. $O$ carvão apresentou os melhores resultados e foi escolhido para a continuidade do trabalho. As interações foram analisadas através de ensaios fluidodinâmicos, isotermas de adsorção, dentre outros. Nas condições experimentais utilizadas, a biomassa aumentou a densidade da partícula, fato que foi comprovado pelos ensaios para determinação da velocidade mínima de fluidificação, de expansão e porosidade do leito, e também de velocidade terminal da partícula isolada. As isotermas de adsorção demonstraram que a presença de matéria orgânica diminuiu em $9 \%$ a adsorção do PCP. O RALF apresentou um comportamento satisfatório no período de operação sem PCP. Nos 105 dias de operação, a eficiência média de remoção de DQO ficou quase sempre superior a $90 \%$, e os outros parâmetros de monitoramento de desempenho apresentaram valores típicos, indicando estabilidade no processo. A presença de PCP no sistema, nas concentrações utilizadas, não alterou a qualidade da biomassa presente, e nem os parâmetros de monitoramento de desempenho, como DQO, alcalinidade, $\mathrm{pH}$ e ácidos voláteis. Mesmo sob condições menos idealizadas, foi observado um desempenho satisfatório do reator na remoção do PCP. Em concentrações variando de 1 a $6 \mathrm{mg} / \mathrm{L}$, foram observadas eficiências médias de remoção de $93 \%$ e $70 \%$, respectivamente, para os 80 dias de operação nessas condições. Diante dos resultados obtidos, foi possível concluir que a remoção de PCP em um RALF pode ser atingida mediante condições operacionais mais simples.

Palavras-chave: pentaclorofenol, reator anaeróbio de leito fluidificado, avaliação de material suporte, interações, fluidodinâmica, isotermas de adsorção. 


\section{ABSTRACT}

FREIRE, F.B. (2005). Anaerobic treatment of effluent cointaining pentachlorophenol in a fluidized bed reactor. Thesis (PhD) - Escola de Engenharia de São Carlos, Universidade de São Paulo, São Carlos, 2005.

The almost total removal of chlorophenols by anaerobic processes has been achieved under high concentrations of organic matter and a considerably large number of carbon sources. However, it is necessary to investigate the performance of such reactors under less idealized conditions. The present work shows the development of a new methodology for evaluating the use of an anaerobic fluidized bed reactor (AFBR) in the pretreatment step of a synthetic substrate containing pentachlorophenol (PCP). In order to do that, the following experimental conditions were used: a single source of carbon; reduced concentrations of organic matter; non-previously adapted biomass, and smaller hydraulic retention times. To achieve the main objective, two reactors, one having a volume of $2.2 \mathrm{I}$ and the other one, $16 \mathrm{I}$, were especially designed; evaluation steps of support material and the study of several interactions (particle/fluid, particles/fluid, bioparticle/fluid, bioparticles/fluid) were carried out, and the performance of the AFBR with and without PCP was analyzed. The three support materials employed were alumina, basalt and granular activated carbon, all having average diameters of $3 \mathrm{~mm}$. These materials were evaluated through physical characterization methods, microscopy, hydrodynamic and image analyses. The activated coal showed the best results and was exclusively employed in the remainder of the work. The interactions were analyzed by hydrodynamics and adsorption isotherms, to name but a few. Under the experimental conditions employed, the biomass made the particle density increase, a fact that was verified in the determination of the minimum fluidization velocity, the bed porosity and expansion as well as the terminal velocity of isolated particles. The adsorption isotherms showed a decrease of $9 \%$ in PCP absorption due to the existence of organic matter. The AFBR showed satisfactory results during the operation without PCP. In the 105 days of operation, the average efficiency of COD removal remained almost always over $90 \%$, while the other performance monitoring parameters remained at typical values, indicating the process stability. The presence of PCP under the concentrations used in the system did not seem to affect neither the quality of the biomass nor the performance monitoring parameters, like COD, alkalinity, $\mathrm{pH}$ and volatile acids. Even under less idealized conditions, the reactor showed good performance in removing PCP. The average efficiencies of removal attained around $93 \%$ and $70 \%$ for concentrations of 1 to $6 \mathrm{mg} / \mathrm{L}$ respectively. These concentration levels were kept during 80 days. In view of the results obtained, it is possible to conclude that reasonably good efficiency of PCP removal in AFBR can be attained under simpler operational conditions.

Keywords: pentachlorophenol, anaerobic fluidized bed reactor, support material evaluation, phase interactions, hydrodynamics, adsorption isotherms. 


\section{INTRODUÇÃO}

Durante séculos a preocupação com as questões ambientais mereceu pouca, ou nenhuma atenção, talvez em decorrência da cobiça econômica e dos benefícios ocasionados pelo desenvolvimento industrial e urbano. Ainda hoje muitos problemas persistem, mesmo com o grande avanço das políticas de proteção ambiental e da conseqüente conscientização sobre essa causa, que tornaram "lugar comum" a afirmação de que desenvolvimento e preservação devem caminhar lado a lado.

Apesar de muitos países elaborarem legislações rigorosas, estabelecendo padrões de emissão de poluentes extremamente restritivos, diversos crimes e irregularidades ambientais cometidos em todo o mundo, por indústrias dos mais variados setores (químicas, florestais, petrolíferas, de mineração, de biotecnologia, nuclear, de armamentos, pesqueira, dentre outras) mostram claramente a necessidade de maior fiscalização, monitoramento e responsabilidade da atividade corporativa em uma economia globalizada.

Os estados são fundamentalmente responsáveis pelo bem-estar de suas populações e não podem abdicar dessa responsabilidade em função de interesses do setor privado. Portanto, ao imporem resistência em aceitar instrumentos internacionais de controle, só aumentam a desconfiança de que há um crescente poderio corporativo sobre eles. Um exemplo claro é a não participação dos Estados Unidos no protocolo de Kyoto, um acordo internacional para reduzir as emissões de gases-estufa dos países industrializados e para garantir um modelo de desenvolvimento limpo aos países em desenvolvimento.

Por outro lado, sabe-se que o problema merece uma abordagem sistêmica e que a política não deve se basear apenas em fiscalização e pesadas multas. A comunidade científica tem papel importantíssimo nesse 
contexto, estudando, desenvolvendo e viabilizando alternativas para minimizar os impactos ao meio ambiente, causados pelas mais diversas formas de poluição. Mesmo em um país em desenvolvimento como o Brasil, onde a isso se soma uma série de outros agravantes e carências, muito se tem evoluído em relação ao tratamento dos poluentes.

No que diz respeito aos efluentes industriais, os compostos organoclorados, tais como os clorofenóis, são objeto de grande preocupação e de estudos sistemáticos, principalmente pela sua elevada toxicidade e pelo seu alto poder de persistência no meio ambiente. Os clorofenóis são utilizados em amplo espectro de atividades, como na preservação de madeira, em herbicidas, fungicidas, biocidas em geral, e aparecem também como subprodutos do branqueamento do papel, em processos que utilizam cloro, na incineração de resíduos municipais, na cloração de águas residuárias, dentre outras.

A degradação lenta dos compostos orgânicos halogenados sob determinadas condições ambientais, bem como os elevados custos e resultados discutíveis de algumas tecnologias de tratamento, tem aumentado o interesse por processos biológicos de degradação. A dificuldade de degradação por processos aeróbios de compostos altamente clorados, e a constatação da existência e degradação destes compostos em ambientes anaeróbios naturais, torna os processos anaeróbios uma ótima alternativa (DAMIANOVIC, 1997).

Os processos biológicos anaeróbios envolvendo reatores com biomassa imobilizada proporcionaram um grande avanço no tratamento das mais diversas substâncias poluentes, principalmente por possibilitarem a retenção de biomassa dentro do sistema, aumentando a relação entre o tempo de retenção celular $\left(\theta_{c}\right)$ e o tempo de detenção hidráulica (TDH ou $\theta_{H}$ ). Dessa forma, além de minimizar a perda de biomassa no efluente, essa técnica permitiu que fossem aplicados $\mathrm{TDH}$ reduzidos, e conseqüentemente, que reatores com volumes menores fossem projetados.

Dos reatores com biomassa imobilizada, o reator anaeróbio de leito fluidificado (RALF) ainda acrescenta outras vantagens, tais como:

- o escoamento permite um ótimo contato entre as fases líquida e sólida; 
- o escoamento também possibilita um ótimo controle da espessura do biofilme;

- são evitados problemas de escoamentos preferenciais, de entupimento, e de retenção de gás, geralmente encontrados em reatores de leito fixo;

- o biofilme fino permite boa difusão do substrato para as camadas mais profundas, não existindo assim camadas inativas.

No Laboratório de Processos Biológicos (LPB) do departamento de Hidráulica e Saneamento da EESC (USP), diversas pesquisas, com diferentes configurações de reatores, vêm sendo realizadas para avaliar o tratamento biológico de organoclorados. Os resultados mais recentes podem ser conferidos nos trabalhos de: Bolaños Rojas (1996), Damianovic (1997), Larizzati (1997), Oliveira (1998), Buzzini (2000), Baraldi (2001) e Montenegro (2001).

Uma constatação notória, entretanto, que deve ser levada em consideração nas investigações futuras, é a necessidade de um "diálogo" mais aprofundado entre as instituições de pesquisa e as indústrias, já que estes compostos tóxicos originam-se de processos tipicamente industriais. É imprescindível que, aliados aos fundamentos dos processos, as abordagens também envolvam questões mais práticas. Essa aproximação se dará, em princípio, através da consideração de alguns aspectos-chave, dentre os quais: situações operacionais mais realistas e otimização das unidades.

Um agravante nessa aproximação é que nem sempre nas pesquisas é possível utilizar efluentes reais contendo compostos perigosos, devido à dificuldade de se coletar "in loco", ocasionada pelos mais variados motivos, dentre eles a distância e o custo de transporte, o elevado volume requerido, as restrições de acesso impostas pelas indústrias ou até mesmo o desconhecimento da origem deste efluente. No Brasil, o mais clorado dos clorofenóis (PCP), após uma série de proibições, tem sua utilização em caráter "oficial" restrita apenas ao processo de preservação da madeira (IDEC, 2003).

Uma alternativa para viabilizar o tratamento biológico anaeróbio destes compostos tóxicos é acrescentá-los a efluentes sintéticos que ofereçam matéria orgânica como fontes de carbono e energia aos microrganismos. Dessa maneira, é possível aplicar tanto condições extremamente favoráveis 
para degradação biológica dos compostos tóxicos quanto condições que impossibilitam o tratamento. Assim, a aplicação dos resultados algumas vezes é restrita.

Entre estas duas situações, extremas e antagônicas, possivelmente deve haver uma grande distância e um campo aberto para investigações. Remoções totais, ou quase totais de PCP já foram atingidas mediante elevada concentração de matéria orgânica (em alguns casos até mais de 6000 mg/L em termos de DQO), e um número considerável de fontes de carbono (DAMIANOVIC, 1997; LARIZZATTI, 1997; OLIVEIRA, 1998; BARALDI, 2001, MONTENEGRO, 2001). É importante agora que condições mais restritivas sejam aplicadas para verificar se os sistemas estão aquém de suas capacidades.

Em um reator de leito fluidificado, com suas características de escoamento bem peculiares, que como já foi dito proporcionam um ótimo contato entre as fases, é possível até que essas restrições não representem uma elevada queda de eficiência. Ou seja, é necessário que se investigue se existe mesmo essa "folga" e, caso isso se confirme, até que ponto se pode chegar sem que a eficiência do sistema seja comprometida de forma considerável.

Outro problema está relacionado com a otimização das unidades. Buzzini (2000) avaliou o desempenho de reatores anaeróbios de manta de lodo e fluxo ascendente (UASB), em escala de bancada, tratando efluentes com compostos organoclorados de indústria de pasta celulósica. A pesquisa demonstrou a aplicabilidade do processo anaeróbio ao tratamento desses efluentes. Entretanto o tempo de detenção hidráulica foi relativamente alto (40 horas) para se conseguir eficiência de remoção de DQO acima de 80\%. Em suas recomendações, Buzzini (2000) indica a "necessidade de estudos para o desenvolvimento de reatores biológicos mais eficientes, ocupando menor volume e, se possível, aliando a esta característica um baixo consumo de energia".

O processo de otimização passa obrigatoriamente por uma mudança de concepção na análise do problema. Em escala industrial, dificilmente uma única unidade de tratamento cumprirá os restritos níveis de descarga exigidos 
pelas legislações, sendo necessário o desenvolvimento de um sistema de tratamento, geralmente com várias unidades.

Dessa maneira, no laboratório, mesmo se uma determinada pesquisa tenha como enfoque um reator, é recomendável que essa unidade sempre seja visualizada (entendida) como uma parte integrante de um "todo", o que faz uma grande diferença em relação a analisá-la isoladamente. Não é necessário que a remoção de poluentes e matéria orgânica seja quase total, o que é praticamente inatingível, mesmo a custo de elevadíssimos tempos de detenção hidráulica, mas sim compatível com as outras unidades do sistema de tratamento. Atualmente diversas alternativas de tratamento combinado são avaliadas, onde em muitos casos a etapa anaeróbia desempenha um papel de pré-tratamento.

A partir dessa premissa, e dando continuidade às pesquisas do Laboratório de Processos Biológicos, este trabalho pretende apresentar uma nova proposta de estudo que leve em consideração o tratamento anaeróbio do PCP sob condições menos favoráveis, aproximando-se assim de uma situação menos idealizada. 


\section{OBJETIVOS}

O objetivo principal do trabalho é apresentar a avaliação de um reator anaeróbio de leito fluidificado (RALF) como etapa de pré-tratamento de um efluente sintético contendo substância tóxica (PCP), submetido às seguintes condições:

- fonte única de carbono;

- concentração mais reduzida de matéria orgânica;

- biomassa não previamente adaptada, e

- menores tempos de detenção hidráulica.

Para tanto, também serão cumpridos os seguintes objetivos específicos:

- avaliação de três materiais suporte, através de ensaios de caracterização física, de fluidodinâmica, de microscopia eletrônica de varredura, de capacidade de imobilização de biomassa e de análise de imagem;

- avaliação da influência da matéria orgânica na adsorção do pentaclorofenol no meio suporte;

- avaliação do desempenho do RALF submetido a diferentes condições operacionais, sem o PCP;

- avaliação do desempenho do RALF submetido a diferentes concentrações de PCP. 


\section{REVISÃO DA LITERATURA}

\subsection{CONSIDERAÇÕES GERAIS}

Pretende-se, nesse capítulo, elaborar uma revisão direcionada, ou seja, englobando exclusivamente as áreas específicas relacionadas com a pesquisa, justamente para se manter ao máximo a coerência com o enfoque do trabalho, e também para não se repetirem enfoques já encontrados em outras publicações, tornando a revisão extensa e generalizada. Entende-se que dessa maneira, direcionada, é possível fazer uma análise mais profunda e esclarecedora das publicações.

Portanto, inicialmente será apresentada uma breve definição dos clorofenóis, com uma descrição da molécula e dos problemas ambientais vinculados a sua utilização. Em Damianovic (1997), dentre outras informações, podem ser obtidas definições químicas extremamente detalhadas, além da abordagem de várias formas de tratamento desses compostos.

As pesquisas mais recentes do LPB envolvendo processos biológicos anaeróbios no tratamento de $\mathrm{PCP}$, já citadas na introdução deste trabalho, serão analisadas na seqüência, com mais riqueza de detalhes.

Em seguida, serão analisados os trabalhos mais relevantes que foram encontrados, envolvendo o tratamento anaeróbio de substâncias com elevado grau de toxicidade. Como a assunto é vasto, já que existem diversas configurações de reatores e inúmeras substâncias poluentes, pretende-se concentrar a linha de abordagem nos reatores anaeróbios de leito fluidificado, e quanto aos compostos orgânicos inibidores, atenção maior será dada aos clorofenóis, principalmente quando se tratar do PCP. Obviamente que, quando houver relevância da citação, outras situações podem ser reportadas.

Um capítulo sobre a fluidodinâmica de reatores de leito fluidificado finaliza essa revisão. 


\subsection{CLOROFENÓIS}

Os clorofenóis são compostos aromáticos clorados, e como qualquer composto que tem elementos pertencentes ao grupo "VII A" da tabela periódica, são ditos halogenados. Os clorofenóis são ainda subdivididos de acordo com o número e a posição do elemento cloro no anel aromático. A posição é definida em sentido horário descontando-se a posição do "O-H", assim como mostra o esquema da Figura 3.1.

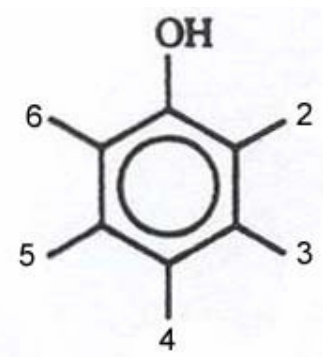

Figura 3.1 - Anel aromático com as respectivas posições.

Sendo assim, o 4 - Clorofenol possui um átomo de cloro na posição quatro, o PCP terá átomos de cloro distribuídos em todas as cinco posições possíveis, o 2,4 - Diclorofenol terá átomos de cloro na posição dois e na posição quatro, o 3,4,5,6 - Tetraclorofenol nas posições três, quatro, cinco e seis, e assim por diante. Exemplos de clorofenóis são apresentados na Figura 3.2 .<smiles>Oc1cc(Cl)c(Cl)c(Cl)c1Cl</smiles>

$3,4,5,6 \mathrm{TeCP}$<smiles>Oc1ccc(Cl)c(Cl)c1</smiles>

$3,4,5$ TCP<smiles>Oc1ccccc1Cl</smiles>

$3,5 \mathrm{DCP}$

Figura 3.2 - Exemplos de clorofenóis.

Como já foi observado, os clorofenóis são utilizados em amplo espectro de atividades, e quantidades significativas podem ser produzidas e alcançar o meio ambiente, fazendo com que esses compostos representem um dos 
principais grupos de poluentes encontrados. De fato os compostos aromáticos clorados são altamente tóxicos a um grande número de organismos e, além de alterarem as propriedades organolépticas da água, como cor e odor (Flora et al., 1994), afetam o sistema imunológico de muitos animais superiores (Blakley et al., 1998), são mutagênicos (Rosa, 1997) e potencialmente carcinogênicos.

Um dos principais problemas é creditado ao chamado caráter recalcitrante dos clorofenóis, ou seja, a grande capacidade de se acumularem no ambiente, em razão de condições ambientais favoráveis, da própria estrutura química da molécula, e também devido ao elevado grau de toxicidade que pode fazer com que esses compostos sejam menos suscetíveis à degradação biológica.

Damianovic (1997) salienta que o caráter recalcitrante de um composto pode ser ocasionado por uma série de fatores:

- resistência inerente à degradação, motivado pela estrutura química;

- fatores ambientais como temperatura, $\mathrm{pH}$, potencial redox, concentração do substrato, salinidade, biodisponibilidade, toxicidade, compostos adicionais, sinergismo e antagonismo; e

- condições biológicas.

Larsen et al. (1991) afirma que "dessa forma, o caráter recalcitrante pode não ser característica do composto e sim das condições ambientais. Pouco é conhecido sobre a influência desses fatores ambientais na atividade desalogenante de aromáticos".

Essa característica de persistência no ambiente e de alta toxicidade para os seres vivos, faz com que em muitos países esses compostos sejam submetidos a legislações cada vez mais restritivas. A utilização do PCP em agrotóxicos foi proibida no Brasil por uma portaria do ministério da agricultura no ano de 1985, e seu transporte, estocagem e uso foram declarados atividades potencialmente poluidoras pela resolução 5 do CONAMA, de 20/11/1985.

Contudo, conseqüências de sua utilização desenfreada até um passado não tão distante e relatos atuais de situações críticas mostram que o problema persiste e está longe de uma solução. No Brasil, um dos casos mais famosos de contaminação por PCP, tanto do meio ambiente como de pessoas, envolve 
a Rhodia S.A., de Cubatão (Greenpeace, 2002). Mais recentemente (agosto de 2003), foram relatados casos sobre a contaminação de adubos à base de esterco de frangos nos estados do Paraná e Santa Catarina fazendo com que o Instituto de Defesa do Consumidor (IDEC) solicitasse junto ao Ministério da Agricultura e à Agência Nacional de Vigilância Sanitária (ANVISA) a proibição total do pentaclorofenol no Brasil (IDEC, 2003).

Além de políticas públicas eficientes, e da fiscalização e punição dos responsáveis, existe a necessidade do desenvolvimento de tecnologias tanto para a recuperação de áreas contaminadas como para o tratamento na fonte de contaminação, que minimiza a possibilidade de eventos como os que foram relatados.

\subsection{AS PESQUISAS DO LPB ENVOLVENDO TRATAMENTO ANAERÓBIO DE PCP}

A Tabela 3.1 mostra um quadro-resumo de algumas das pesquisas mais recentes conduzidas no Laboratório de Processos Biológicos, no que diz respeito ao tratamento de efluentes contendo PCP.

Tabela 3.1 - Resumo de algumas das pesquisas conduzidas no LPB relacionadas com o tratamento anaeróbio de PCP.

\begin{tabular}{|c|c|c|c|c|}
\hline REFERÊNCIA & $\begin{array}{c}\text { DAMIANOVIC } \\
(1997)\end{array}$ & $\begin{array}{c}\text { LARIZZATTI } \\
(1997)\end{array}$ & $\begin{array}{c}\text { OLIVEIRA } \\
(1998)\end{array}$ & $\begin{array}{c}\text { BARALDI } \\
(2001)\end{array}$ \\
\hline processo biológico & ANAERÓBIO & ANAERÓBIO & ANAERÓBIO & ANAERÓBIO \\
\hline tipo de reator & RAHLF & BATELADA & BATELADA & RAHLF \\
\hline volume (ml) & 1991 e 296 & 250 e 1000 & 250 & 1995 \\
\hline diâmetro $(\mathrm{cm})$ & 5 e 2,7 & --- & --- & 5 \\
\hline altura ou comprimento $(\mathrm{cm})$ & 99,5 e 52 & --- & -- & 100 \\
\hline operação (dias) & 109 & 234 e 92 & 18,7 e 19 (cada ensaio) & 240 \\
\hline lodo pré-adaptado? & $\operatorname{sim}$ & $\operatorname{sim}$ & não & não \\
\hline fontes de carbono & 4 & 4 & variável (4 e 2) & 4 \\
\hline organoclorado & PCP & PCP & PCP & PCP \\
\hline concentração PCP (mg/L) & 0,2 a 8,0 & $\sim 5$ & $\sim 2,5$ & 2 a 13 \\
\hline DQO afluente (mg/L) & 3000 & --- & --- & 3000 \\
\hline vazão afluente & 650 e $160 \mathrm{ml} / \mathrm{dia}$ & reator descontínuo & reator descontínuo & $760 \mathrm{ml} / \mathrm{dia}$ \\
\hline temperatura $\left({ }^{\circ} \mathrm{C}\right)$ & 30 & ambiente & 55 & 30 \\
\hline TDH & 25 e $18 \mathrm{~h}$ & --- & --- & 25 \\
\hline remoção PCP (\%) & quase total & (75 a 97$)$ e (90 a 97) & 100 e 80 & 100 \\
\hline remoção DQO (\%) & 97 e 98 & -- & --- & 97 \\
\hline material suporte & espuma poliuretano & -- & -- & espuma poliuretano \\
\hline diâmetro suporte $(\mathrm{mm})$ & 3 & --- & --- & 3 \\
\hline massa suporte $(\mathrm{g})$ & 20,8 e 3,6 & -- & -- & 20,8 \\
\hline
\end{tabular}


Os dados fornecidos na tabela mostram o grande potencial dos processos anaeróbios na remoção de PCP. Damianovic (1997) utilizou o reator anaeróbio horizontal de leito fixo (RAHLF), desenvolvido por Zaiat et al. (1994), para avaliar a remoção de PCP em concentrações variando de 0,2 a 8,0 mg/L. Como efluente sintético foi utilizado meio de cultura baseado em Angelidaki et al. (1990) acrescido de 4 fontes de carbono: glicose, ácido acético, ácido fórmico e etanol. Elevadas remoções de DQO e do PCP foram atingidas. Uma queda na eficiência do reator foi relatada quando este foi submetido a uma concentração de PCP de $8,0 \mathrm{mg} / \mathrm{L}$. A autora, entretanto, não relaciona esta queda à concentração de PCP, e sim a problemas operacionais do reator (caminhos preferenciais).

Larizzatti (1997) e Oliveira (1998) verificaram, respectivamente, a potencialidade em degradar pentaclorofenol (PCP) de lodos anaeróbios metanogênicos em condições mesofílicas e termofílicas, para diferentes fontes de carbono. Os trabalhos enfatizaram aspectos biológicos e a produção de metano. Oliveira (1998), utilizando reatores em batelada com concentração fixa de $\mathrm{PCP}(\approx 2,5 \mathrm{mg} / \mathrm{L})$, em ensaios com duração de 19 dias, observou que aproximadamente $100 \%$ do PCP foi removido na presença de ácidos voláteis (acético, propiônico e butírico) e etanol. Nessas condições foram também obtidas as maiores taxas de produção de metano. Empregando glicose e etanol, a remoção de PCP foi de aproximadamente $80 \%$ e a produção de metano foi muito baixa.

Baraldi (2001) utilizou um RAHLF em condições operacionais muito semelhantes a Damianovic (1997), enfatizando, porém, a caracterização das comunidades microbianas anaeróbias. O processo de inoculação foi realizado através da mistura de um lodo oriundo de reator UASB aplicado ao tratamento de efluentes de indústria de reciclagem de papel e papelão e de outro reator UASB aplicado ao tratamento de esgoto sanitário, na proporção de 70 e $30 \%$, respectivamente. Embora a autora relate a inexistência de adaptação prévia do lodo, pelo fato da mistura não ter sido exposta previamente ao PCP, sabe-se que um contato prévio com compostos clorados (existentes nas indústrias de papel, mesmo nas de reciclagem) pode resultar em uma adaptação mais rápida da biomassa. Através de perfis ao longo do comprimento do reator, Baraldi (2001) verificou que a remoção de matéria orgânica e de PCP ocorreu na parte 
inicial do reator, sugerindo então, para pesquisas futuras, que reatores menores fossem utilizados. Entretanto, devido ao já reduzido volume do reator (cerca de 2 litros), uma boa alternativa também seria a manutenção de suas dimensões e a diminuição do tempo de detenção hidráulica, já que o reator estava operando aquém de sua capacidade.

Outras pesquisas confirmaram a viabilidade dos processos anaeróbios, tanto para a remoção de PCP (MONTENEGRO, 2001; BOLAÑOS ROJAS, 1996) quanto para outros compostos organoclorados (GUAGLIANONI, 1998; BUZZINI, 2000). Dessa maneira, um grande avanço sobre aspectos fundamentais foi obtido, com maior elucidação das reações bioquímicas presentes, das rotas de degradação, e dos microrganismos envolvidos. Os trabalhos também foram igualmente importantes em apontar novas direções a serem tomadas, como a otimização das unidades.

\section{$3.4 O$ LEITO FLUIDIFICADO NO TRATAMENTO ANAERÓBIO DE CLOROFENÓIS}

A partir da segunda metade da década de 80 , o reator anaeróbio de leito fluidificado tem sido empregado de uma maneira sistemática (em escala piloto) no tratamento de compostos orgânicos com elevada toxicidade, destacando-se os trabalhos de Wang et al. (1986) Gardner et al. (1988) e Pfeffer e Suidan (1989), dentre outros.

Verifica-se também que para esses casos, a utilização do carvão ativado granular (CAG) como meio suporte para os microrganismos reproduz a mesma eficiência elevada obtida em trabalhos pioneiros, quando o esgoto doméstico, ou diferentes tipos de águas residuárias "não tóxicas", eram utilizados como efluente.

Exemplos dessas altas eficiências encontradas, bem como outras informações pertinentes, podem ser observados na Tabela 3.2, que apresenta um resumo de alguns trabalhos importantes encontrados na literatura, envolvendo a utilização de reatores anaeróbios de leito fluidificado e expandido no tratamento de substâncias com elevado grau de toxicidade. 
Tabela 3.2 - Resumo de trabalhos envolvendo reatores RALF no tratamento de substâncias tóxicas

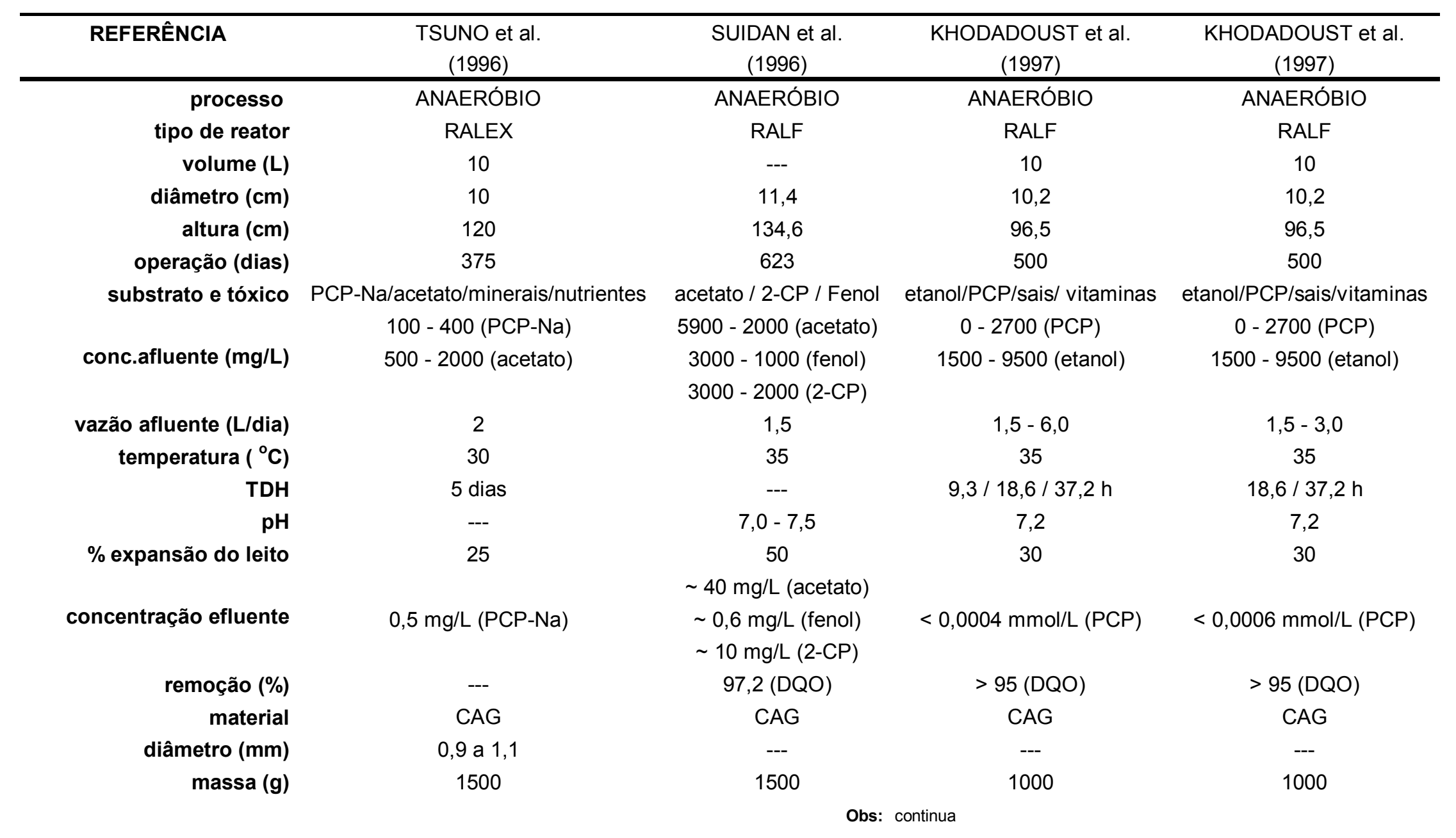


Tabela 3.2 - Resumo de trabalhos envolvendo reatores RALF no tratamento de substâncias tóxicas (continuação)

\begin{tabular}{|c|c|c|c|}
\hline REFERÊNCIA & $\begin{array}{l}\text { KORAN et al. } \\
(2001)\end{array}$ & $\begin{array}{l}\text { WILSON et al. } \\
\qquad(1998)\end{array}$ & $\begin{array}{l}\text { VALLECILLO et al. } \\
\qquad(1999)\end{array}$ \\
\hline processo biológico & ANAERÓBIO & ANAERÓBIO & ANAERÓBIO \\
\hline tipo de reator & RALF & RALF & RALF \\
\hline volume (L) & 11 & 10 & 2,5 \\
\hline diâmetro (cm) & 10,2 & 10,2 & 6 \\
\hline altura $(\mathrm{cm})$ & 96,5 & 96,5 & 80 \\
\hline tempo de operação (dias) & 1135 & 1720 & 325 \\
\hline substrato e tóxico & PCP/ etanol / naftaleno / outros & $\begin{array}{c}\text { PCP / etanol / nutrientes } \\
200 \text { (PCP) }\end{array}$ & $\begin{array}{c}\text { TCP / acido acético / nutrientes } \\
25-100 \text { PPM (TCP) }\end{array}$ \\
\hline concentração afluente (mg/L) & 0,376 mmol/L (PCP) & 1388 (etanol) & 1500 (acido acético) \\
\hline vazão afluente (L/dia) & $6,0-24,0$ & $3,0-24,0$ & --- \\
\hline temperatura $\left({ }^{\circ} \mathrm{C}\right)$ & 35 & 35 & 35 \\
\hline$\theta_{H}$ - tempo de detenção hidráulica & $9,3-2,32 h$ & $18,6-2,32 h$ & $2,5-1,25$ dias \\
\hline $\mathrm{pH}$ & --- & 7,2 & $7,2-7,5$ \\
\hline \multirow[t]{2}{*}{ \% expansão do leito } & 30 & 30 & --- \\
\hline & & $<3.10^{-3} \mathrm{mmol} / \mathrm{L}(\mathrm{PCP})$ & \\
\hline concentração efluente & $<10^{-4} \mathrm{mmol} / \mathrm{L}(\mathrm{PCP})$ & $<10 \mathrm{mg} / \mathrm{L}$ (etanol) & --- \\
\hline Eficiência de remoção (\%) & $>99,8(\mathrm{PCP})$ & $>99(\mathrm{PCP})$ & $>90\left(\mathrm{p} / \theta_{\mathrm{H}}=2,5\right)>80\left(\mathrm{p} / \theta_{\mathrm{H}}=1,25\right)$ \\
\hline material & CAG & CAG & BIOLITA \\
\hline diâmetro (mm) & --- & --- & --- \\
\hline massa $(g)$ & 1000 & 1000 & --- \\
\hline
\end{tabular}

Obs: RALEX - Reator anaeróbio de leito expandido

RALF - Reator anaeróbio de leito fluidificado 
A explicação é complexa, mas sabe-se que esse bom desempenho se deve em certa parte à elevada porosidade da partícula (CAG), que com suas fendas e saliências permitem uma grande adesão e crescimento de microrganismos, além da grande capacidade de adsorção. Nas palavras de Suidan et al. (1996): "Os reatores anaeróbios de leito fluidificado que utilizam carvão ativado granular como meio suporte têm a vantagem de remover por adsorção compostos da solução, e com isso expõe os microrganismos a níveis mais reduzidos desses compostos. Efetivamente, a inibição da atividade microbiana é reduzida, a adaptação é promovida, e a biodegradação é aumentada. Devido à sua elevada capacidade de adsorção e degradação de compostos orgânicos, esses reatores têm sido efetivos em tratar uma ampla cadeia de resíduos tóxicos e inibidores".

Portanto, pode-se dizer que o processo é caracterizado por uma combinação de mecanismos físicos e biológicos de remoção, ou seja, a adsorção no CAG e a degradação biológica nos microrganismos aderidos ao CAG (Tsuno et al., 1996). Nesse trabalho, esses autores realizaram importantes verificações.

Durante 375 dias um reator anaeróbio de leito expandido, tendo como meio suporte para a biomassa o carvão ativado granular, foi operado em duas etapas. Como efluente utilizou-se uma água residuária sintética contendo o pentaclorofenato de sódio $\left(\mathrm{C}_{6} \mathrm{Cl}_{5} \mathrm{ONa}\right)$, acetato de sódio, além de nutrientes, vitaminas e minerais. Na primeira etapa de operação, da partida até o $82^{\circ}$ dia, as concentrações de PCP-Na e de acetato de sódio foram mantidas respectivamente em $100 \mathrm{mg} / \mathrm{L}$ e $500 \mathrm{mg} / \mathrm{L}$. No $83^{\circ}$ dia de operação, com o intuito de se verificar o desempenho do reator mediante um choque de carregamento, essas concentrações foram subitamente aumentadas em quatro vezes, passando respectivamente para 400 e $2000 \mathrm{mg} / \mathrm{L}$.

Além disso, microrganismos coletados no reator no dia 372 foram utilizados para experimentos em batelada de degradação de PCP e 2-CP, com e sem a adição de acetato, para se avaliar a importância da existência de fontes de carbono no processo. Para efeito de controle, as mesmas soluções de PCP e 2-CP foram colocadas em experimentos sem a presença de biomassa, sob as mesmas condições dos outros. 
Antes da operação contínua, porém, experimentos em batelada foram realizados para se verificar o potencial de adsorção do PCP-Na ao carvão ativado granular.

Como resultados do tratamento contínuo, acompanhando a Figura 3.3 nota-se que o reator teve um bom desempenho, sendo que a concentração efluente de PCP-Na foi mantida abaixo de 0,5 mg/L, mesmo logo após a partida do reator, bem como no choque de carregamento ocorrido no $83^{\circ}$ dia.

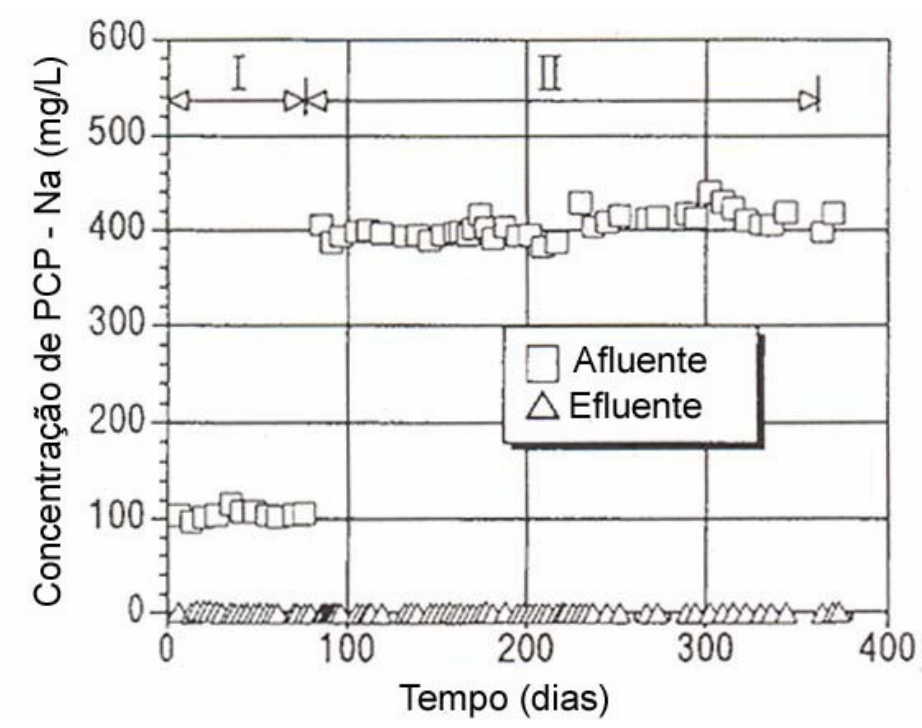

Figura 3.3 - Concentrações afluente e efluente de PCP-Na no RALF utilizado por Tsuno et al. (1996).

Fonte - Tsuno et al. (1996)

O reator respondeu com sucesso a esse aumento de quatro vezes na concentração afluente, sem apresentar, inclusive, acréscimos substanciais na DQO efluente.

Nos experimentos de degradação em batelada, sem a adição de acetato de sódio, a concentração de PCP-Na não decresceu antes dos 10 primeiros dias, caindo depois gradualmente de 14 para $12 \mathrm{mg} / \mathrm{L}$ (Figura 3.4).

Por outro lado, quando o acetato de sódio foi introduzido, com uma concentração inicial de $50 \mathrm{mg} / \mathrm{L}$, a concentração de PCP-Na caiu imediatamente de 9,5 para 4,5 $\mathrm{mg} / \mathrm{L}$, no primeiro dia, caindo gradualmente depois, até atingir o valor 3,8 no sexto dia (Figura 3.5). Esses resultados mostram que o PCP-Na foi removido do sistema pelos microrganismos, e que a presença de uma fonte de carbono é fundamental para viabilizar o processo. $\mathrm{O}$ 
decréscimo da concentração de PCP-Na sem a presença de acetato pode ser explicado tanto por reações de degradação química sem ação biológica quanto pela própria precisão da análise. Damianovic (1997) realizou testes de redução do PCP no efluente, e verificou que para algumas concentrações houve redução de até $13 \%$ após 48 horas, o que prova que no caso de Tsuno et al. (1996), a redução possivelmente aconteceu por este mesmo motivo.

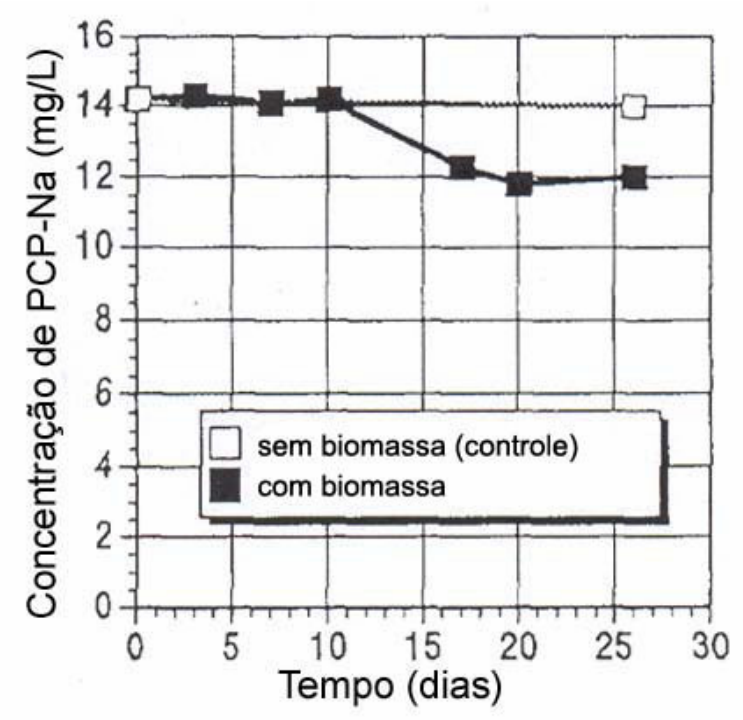

Figura 3.4 - Degradação do PCP-Na sem a adição de acetato em experimentos em batelada realizados por Tsuno et al. (1996).

Fonte - Tsuno et al. (1996)

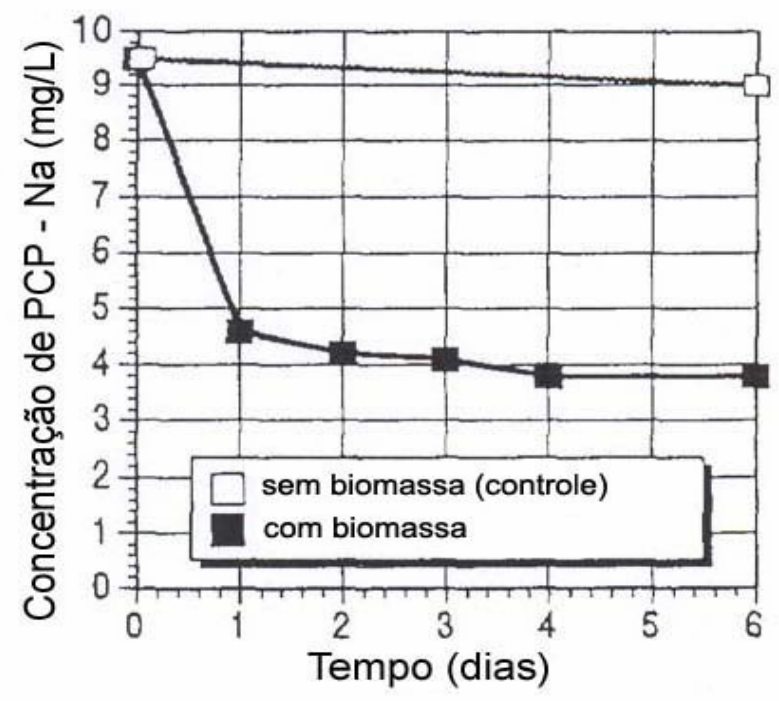

Figura 3.5 - Degradação do PCP-Na com a adição de acetato em experimentos em batelada realizados por Tsuno et al. (1996). 
$\mathrm{Na}$ avaliação do potencial de adsorção através de ensaios de isotermas, os autores obtiveram a seguinte correlação:

$$
W=131 \cdot C^{0,28}
$$

Na qual $\mathrm{W}$ é a massa de PCP-Na adsorvida por unidade de massa de CAG (mg/g CAG) e C é a concentração de PCP-Na na fase líquida. O resultado obtido se ajustou a uma isoterma de Freundlich típica.

Através de correlações e da adoção de algumas hipóteses, como a de que o acetato é totalmente convertido a metano, os autores relacionaram a degradação biológica de PCP-Na com a produção de metano, e demonstraram que cerca de $60 \%$ de toda a remoção do PCP-Na do sistema foi obtida devido à degradação biológica, e $40 \%$ dessa remoção deveu-se à adsorção pelo CAG e/ou transformação em produtos intermediários.

Para algumas situações específicas, é preciso tomar um certo cuidado com associações entre produção de gás metano e degradação biológica. Como já foi observado nesta revisão, Oliveira (1998), realizando ensaios em batelada para avaliar a potencialidade de um lodo em degradar o PCP, mostrou que na presença de glicose como fonte de carbono, houve uma remoção de cerca de $80 \%$ do PCP. Pode-se afirmar que grande parte dessa remoção foi ocasionada por degradação biológica, já que o sistema era constituído por biomassa e efluente, sem a presença de partículas. No entanto, a produção de gás metano foi extremamente baixa, mostrando que é plenamente possível ocorrer degradação biológica com pouca produção de gás metano. Neste caso, a indicação da presença de metabólitos (intermediários), mesmo em quantidades "traço", foi mais adequada para comprovar a degradação biológica.

Assim como Tsuno et al. (1996), outra considerável parcela de pesquisadores investiga o potencial de adsorção do carvão ativado, bem como os efeitos de choques de carregamento no reator. Suidan et al. (1996) investigaram os efeitos de um amplo e súbito aumento no carregamento afluente de um reator de leito fluidificado com carvão ativado granular. Segundo os autores, "elevados níveis de fenóis, 2-CP e clorofenóis, em geral, mostram-se inibidores da atividade biológica". 
Para tanto, esse reator foi inicialmente alimentado com uma solução sintética contendo basicamente fenol, na concentração de $3000 \mathrm{mg} / \mathrm{L}$, e acetato de sódio, com concentração de $5900 \mathrm{mg} / \mathrm{L}$, além de soluções tampão, para manter o pH constante, e micro-nutrientes (sais inorgânicos e vitaminas). No $70^{\circ}$ dia o 2-CP foi introduzido no sistema em pequenos incrementos, até atingir a concentração de $3000 \mathrm{mg} / \mathrm{L}$, e a partir daí os pesquisadores, em dias definidos, diminuíram as concentrações desses três compostos principais, como pode ser verificado na Tabela 3.3, para verificar a resposta do reator, totalizando mais de 680 dias de operação.

Tabela 3.3 - Fases e parâmetros operacionais de um RALF tratando fenol e 2 - CP, em trabalho de Suidan et al. (1996).

\begin{tabular}{cccccc}
\hline \multirow{2}{*}{ FASE } & DIA & pH & \multicolumn{3}{c}{ concentrações afluentes (mg/L) } \\
\cline { 5 - 6 } ICETATO & FENOL & 2-CP \\
\hline II & 70 & 7,0 & 5900 & 3000 & 3000 \\
& 315 & 7,0 & 5900 & 3000 & 3000 \\
& 420 & 7,5 & 5900 & 3000 & 2000 \\
III & 518 & 7,5 & 2000 & 1000 & 2000 \\
& 581 & 7,5 & 2000 & 1000 & 2000 \\
& 623 & 7,5 & 2000 & 1000 & 2000 \\
\hline
\end{tabular}

Fonte: adaptado de Suidan et al. (1996)

Após 12 semanas do início da fase III um pulso extra contendo $4 \mathrm{~L}$ de uma solução "estoque" orgânica foi introduzido na entrada do reator, contendo $16 \mathrm{~g}$ de acetato, $8 \mathrm{~g}$ de fenol, e $16 \mathrm{~g}$ de 2-CP.

Outra verificação importante dos autores foi o estudo da reposição parcial de carvão ativado granular, visto que a exaustão da capacidade desse carvão em adsorver compostos tóxicos não biodegradáveis pode conduzir a um aumento desses compostos na solução, resultando numa possível inibição biológica, e em caso extremos, levar o reator ao colapso. Nesse caso, assim como no trabalho de Gardner et al. (1988) os autores concluíram que a reposição não seria necessária. Por outro lado, Flora et al. (1994) demonstrou que a contínua reposição de carvão ativado granular controlou um provável aumento de para-clorofenol (4-CP) em um reator de leito fluidificado.

Como resultados, durante todo o experimento observou-se uma eficiência média de remoção de DQO de 97,2\%, ou seja, sustentou-se uma 
qualidade do efluente mesmo quando os parâmetros de operação foram variados. A variação do $\mathrm{pH}$ de 7,0 para 7,5 proporcionou uma pequena melhora na qualidade do reator. $O$ aumento súbito no carregamento orgânico aplicado no final da fase III foi satisfatoriamente assimilado pelo reator, como pode ser observado na Figura 3.6, porém uma interrupção na produção de gás foi rapidamente constatada. Isso porque o choque proporcionou um aumento do $\mathrm{pH}$ (passando de 7,5 para 9,1), ou seja, um valor prejudicial aos microrganismos anaeróbios. Uma redução do $\mathrm{pH}$ para 7,5 foi providenciada com a adição de ácido fosfórico.

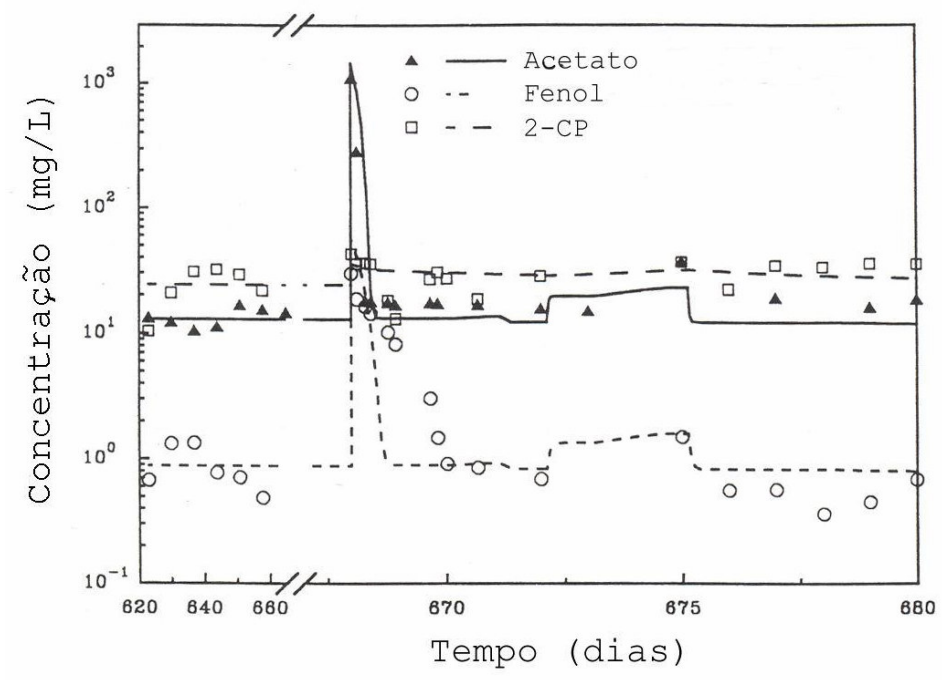

Figura 3.6 - Qualidade do efluente do RALF após o pulso "extra" contendo $4 \mathrm{~L}$ de uma solução orgânica com $16 \mathrm{~g}$ de acetato, $8 \mathrm{~g}$ de fenol, e $16 \mathrm{~g}$ de 2-CP, em trabalho de Suidan et al. (1996).

Fonte: Suidan et al. (1996)

A Figura 3.6 mostra que, logo após o pulso, houve um aumento substancial na concentração de acetato e fenol e um pequeno aumento na concentração de 2-CP efluente. Isso indica, segundo os autores, que o carvão ativado granular adsorveu a maior parte do 2-CP e parte do fenol, enquanto o acetato não foi adsorvido. Mesmo assim, para o acetato e o 2-CP, as concentrações se estabilizaram um dia após o choque, e já para o fenol, a assimilação demorou dois dias.

Finalizando o trabalho, Suidan et al. (1996) apresentaram ainda um modelo matemático desenvolvido para investigar a interação entre a adsorção e a degradação biológica de compostos no reator durante pulsos de grande 
intensidade no afluente, para confrontar com os valores obtidos experimentalmente. Os resultados do modelo apresentaram uma boa similaridade aos dados obtidos experimentalmente. Esse modelo demonstrou claramente o potencial de adsorção do CAG no reator, mostrando que ocorreu um pequeno aumento na concentração de 2-CP depois do choque na entrada, confirmando que o CAG controlou o crescimento de 2-CP no sistema.

Entretanto, o modelo mostrou um rápido declínio na concentração de fenol no efluente, após o pulso, enquanto que nos dados experimentais foi verificado um declínio relativamente gradual, que pode ter sido causado por uma cinética de inibição, como também pela retirada ou liberação do fenol adsorvido pelo carvão, no fenômeno também conhecido como dessorção.

Ainda no que se refere aos choques de carregamento, observa-se que além dos choques na carga orgânica, uma outra verificação importante tem sido analisar a resposta dos reatores submetidos também a aumentos na carga hidráulica, como Khodadoust et al. (1997) realizaram em um reator anaeróbio de leito fluidificado com carvão ativado granular. Dois reatores idênticos ( $A$ e $B$ ) foram construídos a fim de se comparar os efeitos de cargas hidráulicas diferentes. Como afluente, foi utilizado um efluente sintético contendo PCP, etanol, além de sais minerais, vitaminas e uma solução tampão para manter o $\mathrm{pH}$ constante em 7,2. O PCP foi introduzido no sistema a partir do $44^{\circ} \stackrel{\text { dia. }}{\mathrm{A}}$ Tabela 3.4 mostra com detalhes cada fase da pesquisa, com seus respectivos parâmetros de operação.

Analisando a Tabela 3.4, percebe-se que até a fase III a variação dos parâmetros operacionais aplicados aos dois reatores foi idêntica, sendo que no início da fase IV a vazão de entrada no reator A foi aumentada em 100\%, ou seja, de 3 L/dia para 6 L/dia, sendo que no reator B ela foi mantida em 3 L/dia até o final do experimento. Com isso, a partir dessa fase, o reator A operou com um tempo de detenção hidráulica $50 \%$ menor do que o reator B. Nessa fase, ambos os reatores foram submetidos ao dobro da carga de PCP (4 g/dia) e etanol $(28,51 \mathrm{~g} / \mathrm{dia})$ aplicada na fase anterior. Isso foi obtido, no reator $\mathrm{A}$, através do aumento da vazão e manutenção das concentrações, e no reator $B$, através da manutenção da vazão e do aumento da concentração de PCP e etanol no afluente. 
Tabela 3.4 - Fases e parâmetros operacionais de um RALF tratando PCP (KHODADOUST et al., 1997).

\begin{tabular}{cccccc}
\hline & & \multicolumn{2}{c}{$\begin{array}{c}\text { CARGA } \\
\text { VA/dia) }\end{array}$} & \multicolumn{2}{c}{ VAZÄO } \\
(L/dia) \\
\cline { 3 - 6 } FASE & DIAS & PCP & ETANOL & A & B \\
\hline I & $1-44$ & 0,0 & 7,13 & 1,5 & 1,5 \\
& $44-69$ & 4,0 & 7,13 & 1,5 & 1,5 \\
II & $69-142$ & 1,0 & 7,13 & 1,5 & 1,5 \\
III & $142-216$ & 2,0 & 14,26 & 3,0 & 3,0 \\
IV & $216-286$ & 4,0 & 28,51 & 6,0 & 3,0 \\
& $286-300$ & 4,0 & 28,51 & 6,0 & 3,0 \\
& $300-310$ & 4,0 & 28,51 & 6,0 & 3,0 \\
V & $310-354$ & 2,0 & 28,51 & 6,0 & 3,0 \\
VI & $354-434$ & 0,6 & 4,28 & 6,0 & 3,0 \\
& $434-486$ & 0,6 & 4,28 & 6,0 & 3,0 \\
& $486-500$ & 0,6 & 4,28 & 6,0 & 3,0 \\
\hline
\end{tabular}

Fonte: adaptado de Khodadoust et al. (1997)

Os resultados obtidos para a eficiência de remoção de DQO, bem como as taxas de produção de metano, para as seis fases do experimento e os dois reatores, são mostrados na Figura 3.7.

Depois da adaptação inicial da cultura anaeróbia, a eficiência na remoção de DQO, para ambos os reatores, da fase I à fase III, foi maior que $98 \%$, e a produção de metano ficou entre 70 e $80 \%$ da DQO afluente. As diferenças de desempenho entre os dois reatores ficam mais evidentes a partir da segunda metade da fase IV, justamente quando os parâmetros operacionais foram distintos. Nessa fase, a remoção de DQO e as taxas de produção de metano, no reator $\mathrm{A}$, caíram substancialmente, chegando a valores menores que 60 e $50 \%$, respectivamente, enquanto que no reator $B$, as quedas foram bem mais modestas, 90 e $70 \%$, respectivamente.

Um comportamento similar à fase IV foi verificado nas fases subseqüentes, mostrando que o reator $B$ foi submetido a uma inibição menos severa que o reator $A$, provavelmente porque o maior tempo de detenção hidráulica no reator $B$ (exatamente o dobro do aplicado ao reator $A$ ) aparentou ser uma variável operacional mais importante do que as concentrações de alimentação, que para esse mesmo reator, foram duas vezes maiores às aplicadas ao outro. 


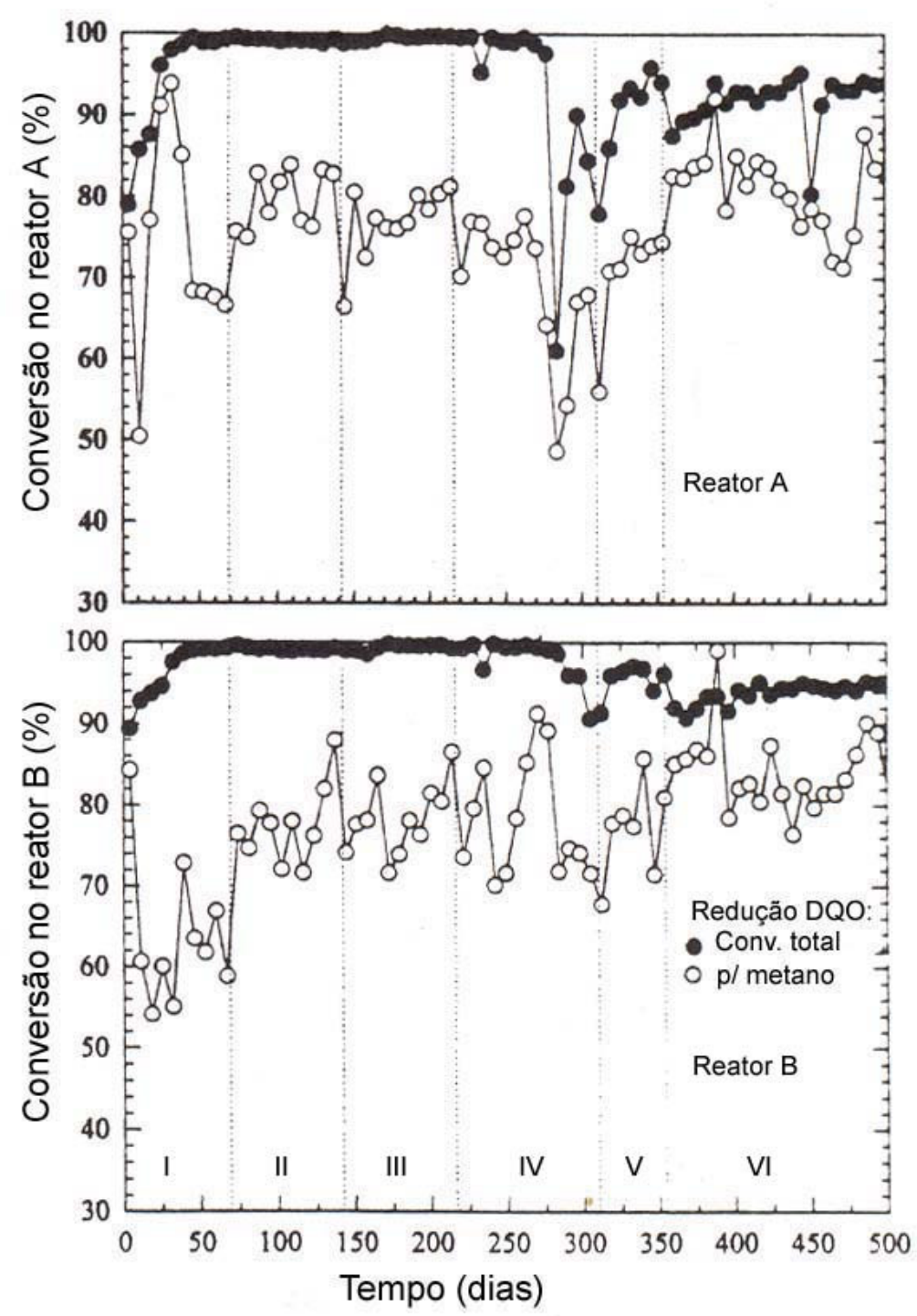

Figura 3.7 - Eficiência de remoção de DQO e conversão para metano em dois reatores RALF submetidos a vazões diferentes a partir da fase IV (KHODADOUST et al., 1997).

Fonte: Khodadoust et al. (1997)

Além disso, análises indicaram a presença de uma concentração elevada de 4-CP no efluente, como pode ser verificado nas Figuras ${ }^{1} 3.8$ e 3.9 para os reatores $\mathrm{A}$ e $\mathrm{B}$ respectivamente, que mostram que, a partir da fase II, a crescente presença no efluente de produtos da transformação biológica do

\footnotetext{
${ }^{1}$ Algumas figuras não possuem o mesmo padrão de qualidade pois foram obtidas por processo de digitalização, e outras já apresentavam qualidade inferior na publicação original. Mesmo assim considerou-se que elas são importantes para o entendimento dos trabalhos.
} 
PCP, tais como monoclorofenóis (MCP), diclorofenóis ( $\mathrm{DCP})$, fenóis, além do próprio $\mathrm{PCP}$, também pode ter contribuído de alguma forma com os processos inibitórios.

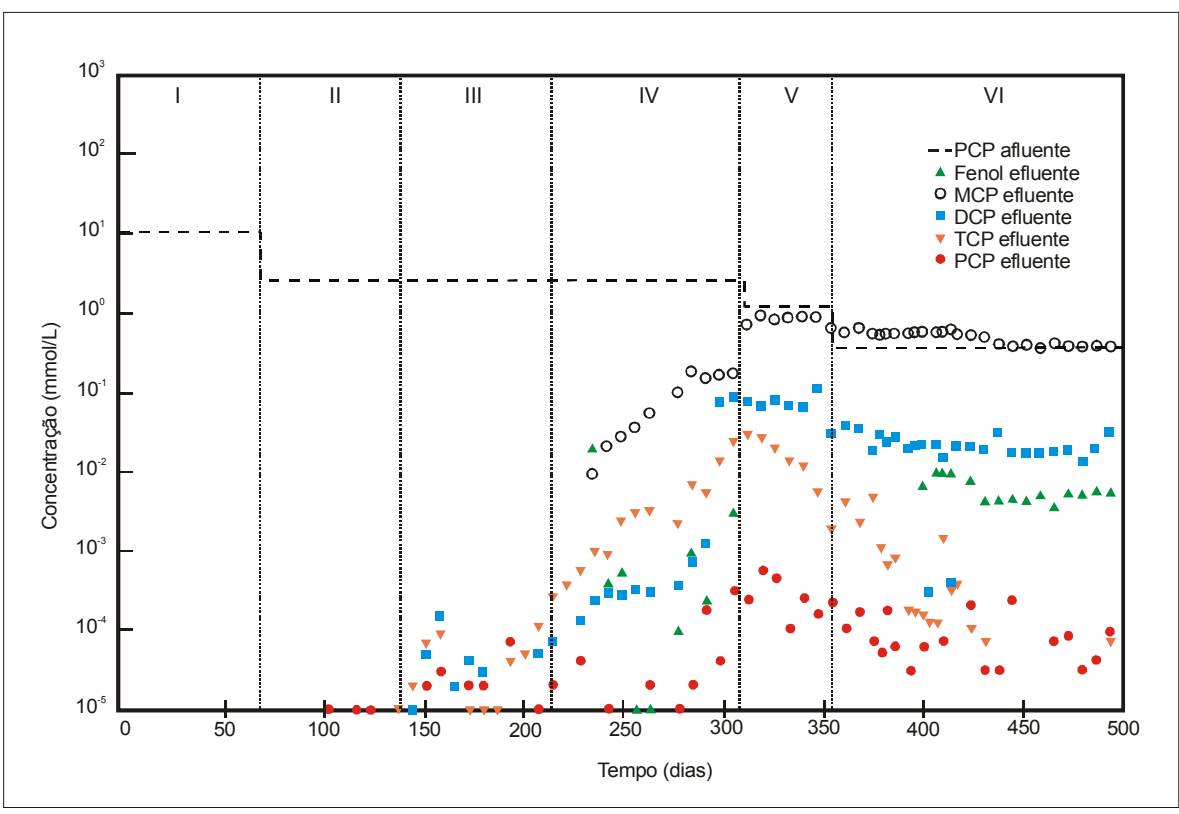

Figura 3.8 - Transformação do PCP em outros clorofenóis durante a operação do RALF A (KHODADOUST et al., 1997).

Fonte: Khodadoust et al. (1997)

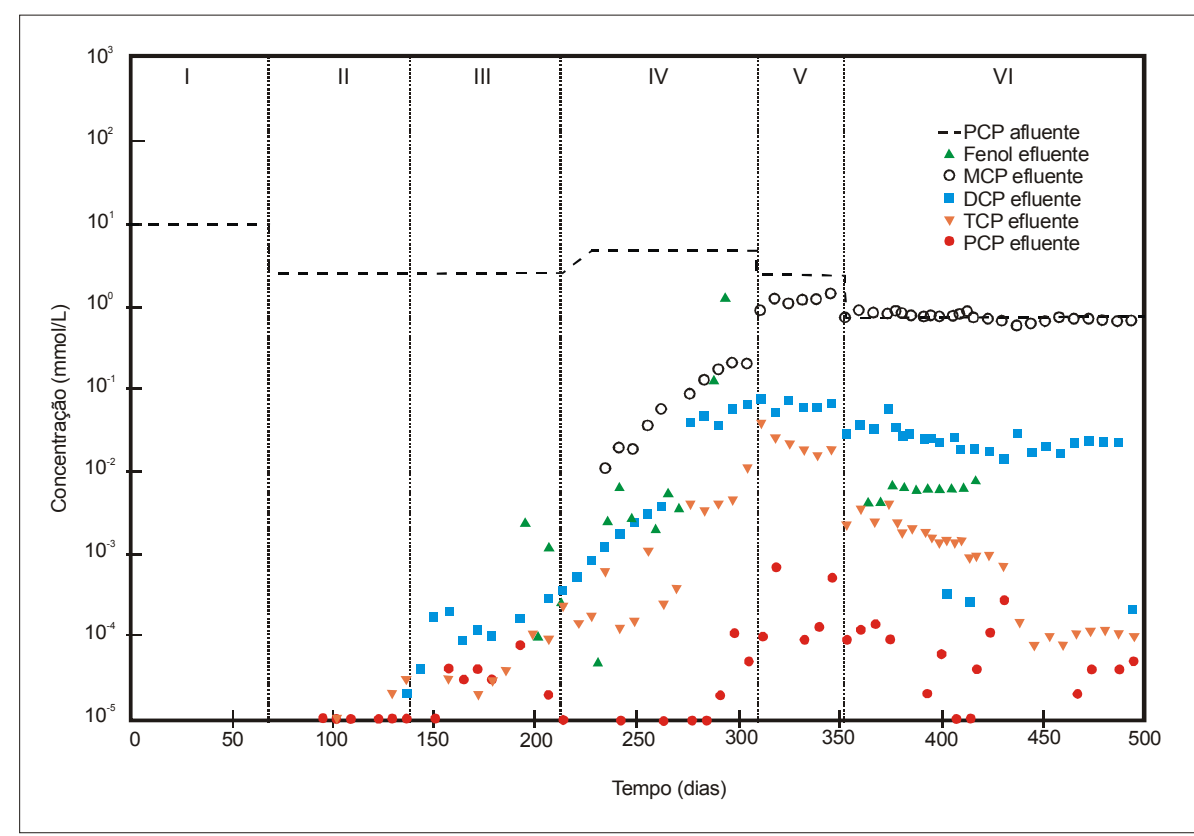

Figura 3.9 - Transformação do PCP em outros clorofenóis durante a operação do RALF B (KHODADOUST et al., 1997).

Fonte: Khodadoust et al. (1997) 
A identificação qualitativa e quantitativa desses produtos intermediários é importante para sugerir prováveis caminhos de degradação do $\mathrm{PCP}$, e com isso identificar com mais facilidade o composto causador da inibição, caso ela aconteça, ou a adaptação do consórcio bacteriano a esses compostos.

O aparecimento de compostos intermediários (metabólitos) no efluente, se por um lado representa ainda perigo potencial ao meio ambiente, dependendo das concentrações encontradas, por outro lado é um indicativo inquestionável da atividade biológica. Khodadoust et al. (1997) sugerem, através da análise das concentrações ao longo de todo o experimento, dois caminhos de transformação para o PCP, apresentados nas Figuras 3.10 e 3.11 .

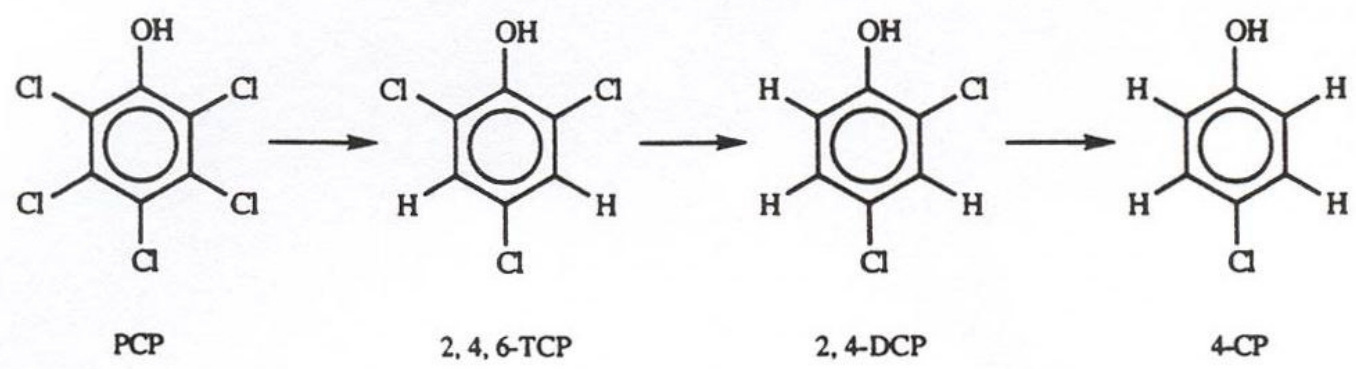

Figura 3.10 - Primeiro caminho de degradação provável do PCP no RALF (KHODADOUST et al., 1997).

Fonte: Khodadoust et al. (1997)

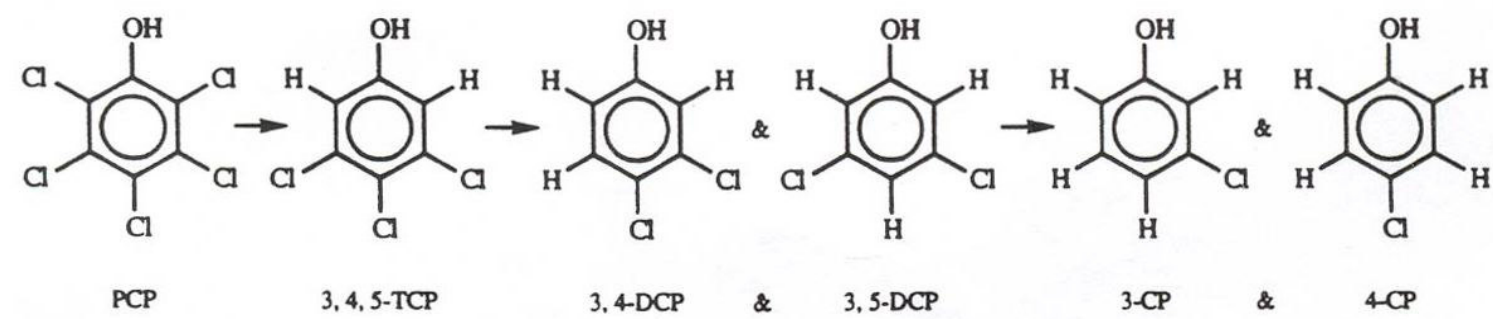

Figura 3.11 - Segundo caminho de degradação provável do PCP no RALF (KHODADOUST et al., 1997).

Fonte: Khodadoust et al. (1997)

A primeira rota de degradação vai da fase II à metade da fase IV, e a segunda, da segunda metade da fase IV até o fim do experimento.

Segundo Annachhatre e Gheewala (1996), em ambientes anaeróbios a degradação biológica de aromáticos clorados ocorre primeiramente através da desalogenação redutiva, que conduz à formação de compostos menos tóxicos 
e mais biodegradáveis. Para o 2,4 Diclorofenol, por exemplo, Zhang e Wiegel (1990) sugerem que a desalogenação redutiva é seguida da carboxilação, da quebra do anel e acetogênese, e finalmente a metanogênese, que conduzirá para a sua completa mineralização. A Figura 3.12 apresenta um esquema desse caminho.

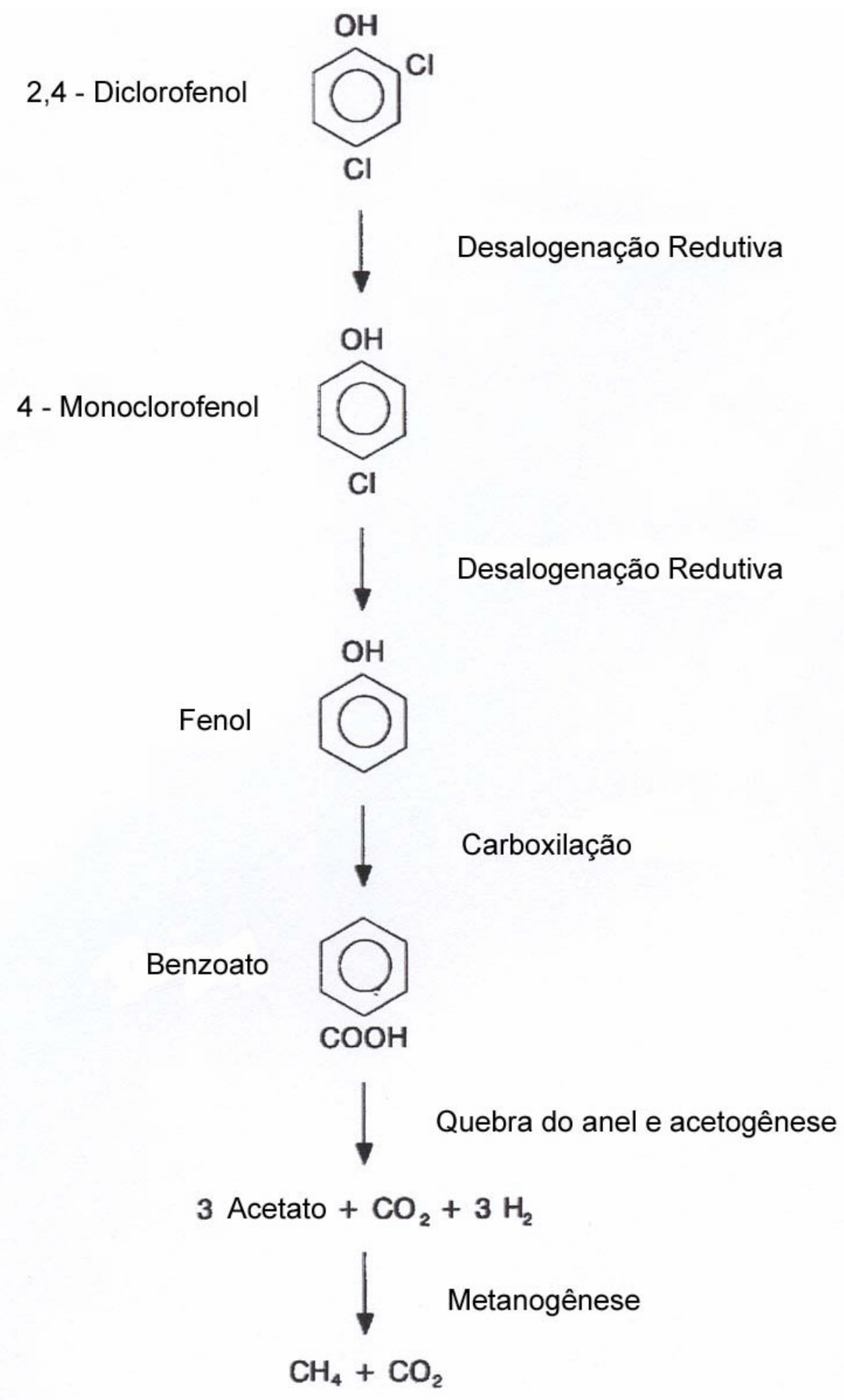

Figura 3.12 - Caminhos para a degradação do 2,4 - Diclorofenol iniciado pelo processo de desalogenação redutiva (ZHANG E WIEGEL, 1990).

Fonte: Zhang e Wiegel (1990) 
Segundo Baraldi (2001), a desalogenação redutiva é o fenômeno mais importante envolvido na transformação desses poluentes. Esse fenômeno ocorre preferencialmente em ambientes anaeróbios, pois esses processos, que incluem a biorremediação aplicada à degradação de compostos artificialmente sintetizados, especialmente os organoclorados, apresentam como um dos princípios fundamentais a ocorrência de reações de óxido-redução. Em suas respectivas revisões bibliográficas, Damianovic (1997), Larizzatti (1997), Oliveira (1998), Buzzini (2000) e Baraldi (2001) fazem uma abordagem minuciosa do processo de desalogenação redutiva.

Wilson et al. (1998) também verificaram a evolução de produtos intermediários ao longo dos 1720 dias da pesquisa experimental, além de definirem parâmetros de operação para um reator anaeróbio de leito fluidificado submetido a concentrações constantes de PCP e etanol no afluente. A carga hidráulica foi aumentada em grandes proporções para se avaliar a resposta do reator frente a essa diminuição do tempo de detenção hidráulica. As fases de operação, bem como seus respectivos parâmetros, são mostradas na Tabela 3.5 .

Tabela 3.5 - Fases e parâmetros de operação de um RALF tratando PCP (WILSON et al., 1998).

\begin{tabular}{|c|c|c|c|c|c|}
\hline \multirow[b]{2}{*}{ FASE } & \multirow[b]{2}{*}{ DIAS } & \multicolumn{2}{|c|}{$\begin{array}{r}\text { CARGA } \\
\text { (g/dia) }\end{array}$} & \multirow{2}{*}{$\frac{\text { VAZÃO }}{\text { (L/dia) }}$} & \multirow{2}{*}{$\begin{array}{c}\theta_{\mathrm{H}} \\
(\mathrm{hs}) \\
\end{array}$} \\
\hline & & $\overline{\mathrm{PCP}}$ & ETANOL & & \\
\hline 1 & $480-606$ & 0,6 & 4,28 & 3 & $\overline{18,60}$ \\
\hline II & $607-824$ & 1,2 & 8,33 & 6 & 9,30 \\
\hline III & $825-999$ & 2,4 & 16,66 & 12 & 4,65 \\
\hline IV & $1000-1720$ & 4,8 & 33,32 & 24 & 2,32 \\
\hline
\end{tabular}

Fonte: Wilson et al. (1998)

Os autores verificaram que o reator apresentou um comportamento estável para a faixa aplicada de tempos de detenção hidráulica, ou seja, de 18,6 até 2,3 horas, e, além disso, o PCP foi estequiometricamente convertido a clorofenol de uma maneira similar em todas as fases da pesquisa, como se observa na Figura 3.13. Essa verificação é muito importante, já que a diminuição do tempo de detenção hidráulica não inibiu a degradação do PCP e seus intermediários, e sabe-se que um menor tempo de detenção hidráulica 
permite que reatores menores tratem uma mesma quantidade de resíduos, possibilitando uma significativa redução de custos. É interessante observar o elevado tempo de operação do reator (mais de 1700 dias), que certamente proporcionou uma eficiente adaptação da biomassa, um dos prováveis motivos para o bom desempenho do RALF utilizado.

A título de curiosidade, os fenóis e clorofenóis remanescentes do processo anaeróbio foram completamente (nas palavras dos autores) removidos por processo aeróbio, também por um reator de leito fluidificado.

Como já foi observado anteriormente, é notório o ótimo desempenho dos reatores anaeróbios de leito fluidificado tendo o carvão ativado granular como meio suporte, e são muitos os casos em que esse tipo de material foi utilizado com sucesso, dos quais uma parte está relatada nessa revisão.

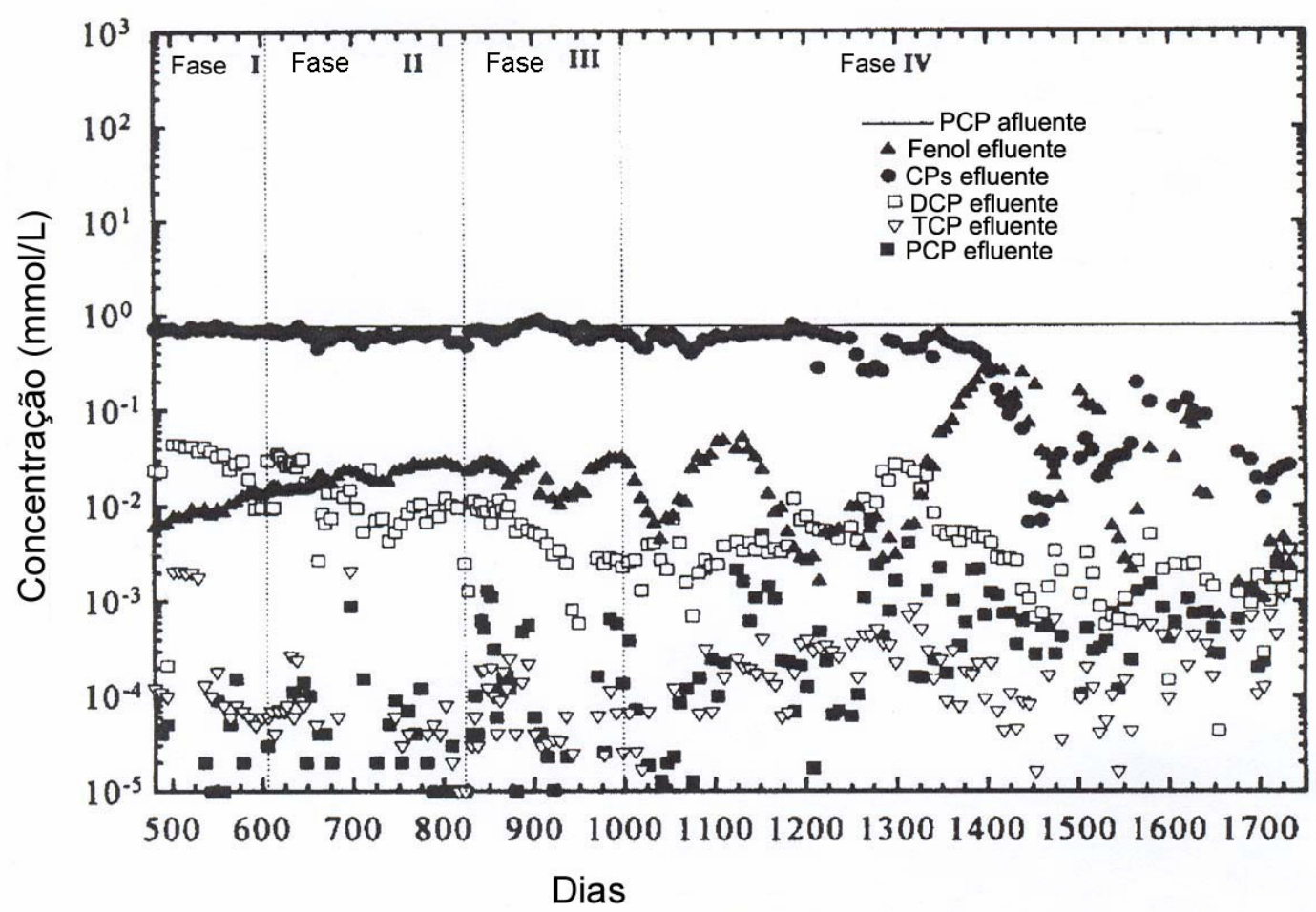

Figura 3.13 - Transformação do PCP em outros clorofenóis durante a operação do RALF (WILSON et al., 1998).

Fonte: Wilson et al. (1998)

Obedecendo a um dos princípios básicos da ciência, que é a de buscar tecnologias cada vez melhores e viáveis economicamente, diversos outros 
materiais são avaliados como alternativas para o meio suporte de biomassa, onde o carvão ativado é muitas vezes empregado como uma espécie de "padrão para comparações" com esses materiais, justamente por ter sua utilização comprovada e consolidada, podendo-se ter um certo conhecimento prévio de seu comportamento.

A biolita, uma rocha escura de origem orgânica onde predomina material ferro-magnesiano, foi utilizada como meio suporte no trabalho de Vallecillo et al. (1999), que operaram por 325 dias um reator anaeróbio de leito fluidifcado tratando uma água residuária sintética com diferentes concentrações de 2,4,6 Triclorofenol (de 25 a 100 ppm) e acido acético como fonte de carbono, além de solução de nutrientes e tampão, para manter $\circ \mathrm{pH}$ entre 7,2 e 7,5. Inicialmente o reator foi operado com um tempo de detenção hidráulica de 2,5 dias, que depois foi diminuído para 1,25 dia durante o último período de corrida. A Figura 3.14 mostra a desempenho do reator no tempo, representando a $\mathrm{DQO}$ e a concentração de 2,4,6 - TCP no afluente e no efluente, bem como a porcentagem de remoção.
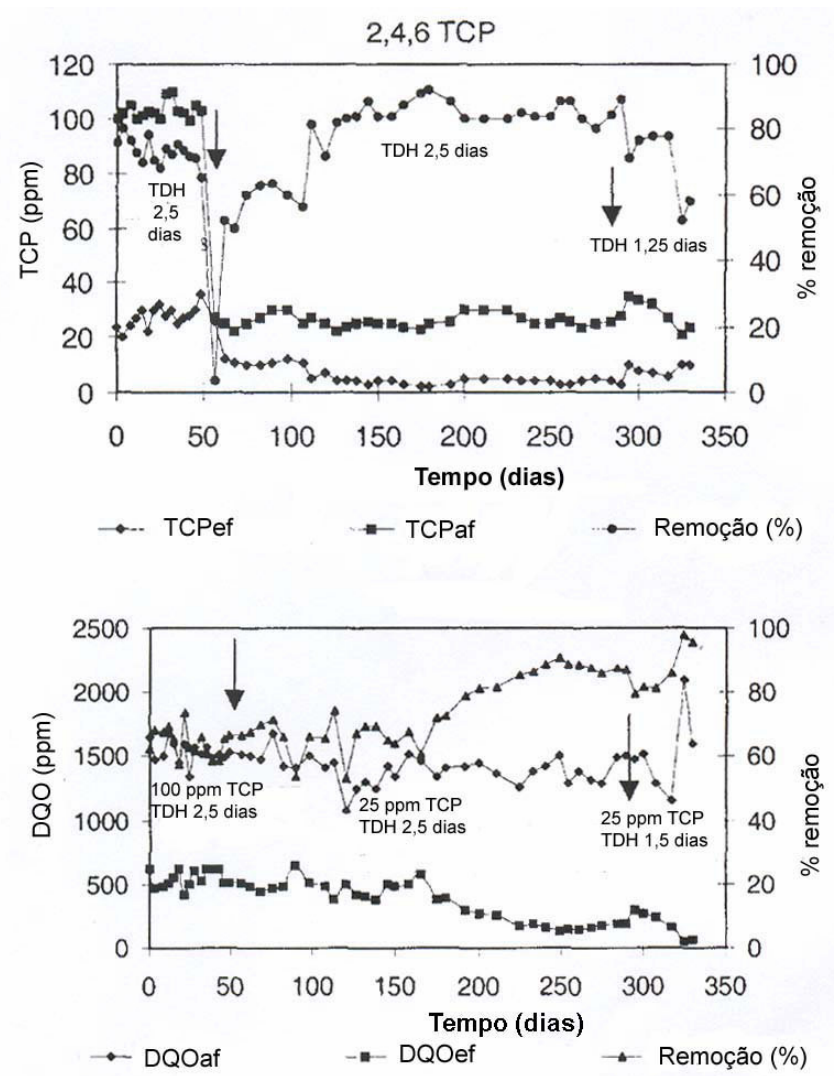

Figura 3.14 - Remoção de TCP e DQO durante a operação do RALF

(VALLECILLO et al., 1999).

Fonte: Vallecillo et al. (1999) 
Durante a operação do reator foi observado um contínuo aumento na remoção de DQO, atingindo valores maiores que 90\%, mostrando-se ser um sistema estável até mesmo após as mudanças operacionais. O reator se mostrou igualmente estável na remoção de 2,4,6 TCP quando as condições operacionais foram constantes. Após 114 dias um aumento no carregamento hidráulico e orgânico, com diminuição de tempo de detenção hidráulica para 1,25 dia causou um desequilíbrio no reator e uma rápida mudança na remoção de DQO, a remoção de 2,4,6 TCP decresceu para 55\%. Um curto período de tempo, de cerca de 10 dias, foi necessário para a recuperação da remoção de DQO, voltando aos níveis observados anteriormente, enquanto um período maior, cerca de trinta dias, foi necessário para que a remoção de TCP voltasse aos mesmos níveis outrora obtidos. Isso indica que a biomassa responsável pela degradação biológica do TCP talvez seja mais sensível a mudanças nas condições operacionais, necessitando de um maior tempo para adaptação.

\subsection{FLUIDODINÂMICA DE REATORES DE LEITO FLUIDIFICADO}

Nos reatores de leito fluidificado, particularmente na área de concentração de tratamento biológico, o estudo da fluidodinâmica tem geralmente como ponto de partida a adoção de um sistema trifásico, ou seja, o leito como sendo composto por uma fase gasosa, uma líquida e outra sólida.

De fato, Merchant et al. (1987) ${ }^{2}$ apud Briens et al. (1997a) observam que "a fluidificação em três fases pode também ser aplicada a muitos processos biológicos e bioquímicos, utilizando como fase sólida células imobilizadas...". Em alguns casos, porém, dependendo da circunstância, o sistema pode ainda ser considerado bifásico, desprezando-se a fase gasosa, e considerando apenas as fases líquida e sólida. Fan (1996) faz uma importante revisão sobre o fenômeno de fluidificação e dá exemplos de pesquisas e aplicações, tanto para leitos trifásicos como bifásicos.

Muitas definições para a fluidificação são propostas, e ainda não há um consenso entre os pesquisadores, até mesmo porque a introdução do termo "leito expandido" contribuiu para a diversidade de opiniões. Uma definição

\footnotetext{
${ }^{2}$ Merchant et al. (1987). A novel Technique for Measuring Solute Diffusivities in Entrapment Matrices Used in Immobilization. Biotech. Bioeng., v. 30, 936.
} 
muito respeitada diz que um leito trifásico é fluidificado quando a mistura gás / líquido / sólido assume propriedades macroscópicas de um fluido homogêneo. Nesse caso, a queda de pressão hidrostática no leito pode ser diretamente determinada através da densidade média da mistura multiplicada pela aceleração da gravidade (g). Em outras palavras, a definição diz que a queda de pressão ao longo do leito é linear em relação velocidade e, a partir de um valor específico de velocidade ascensional (denominado velocidade de mínima fluidificação), permanece constante.

Essa definição é simples e parece ser a mais correta, já que é baseada em constatações físicas. Assim, a velocidade de mínima fluidificação sinaliza a transição entre o comportamento inicial de leito fixo para o de leito fluidificado (Asif e Ibrahim 2002).

Um processo essencial para a operação bem sucedida de leitos fluidificados trifásicos é a determinação acurada da velocidade mínima de fluidificação, um parâmetro crucial no projeto de reatores ou outros dispositivos de contato baseados na tecnologia de leitos fluidificados. Acima dessa velocidade mínima, há um bom contato entre as fases. Obviamente que essa melhora de contato com a velocidade está condicionada a um certo intervalo limite, e estudos também tem sido realizados para se avaliar o comportamento fluidodinâmico a elevadas velocidades.

Medidas de pressão no leito, bem como observações visuais têm sido comumente utilizadas para medir (ou estimar) a velocidade mínima de fluidificação. Isso pode ser verificado na Tabela 3.6 que apresenta um resumo de importantes estudos fluidodinâmicos que utilizaram essas duas técnicas.

Para sistemas bifásicos (líquido / sólido) de fluidificação, um gráfico de queda de pressão através do leito (ou gradiente de pressão no leito) em função da velocidade superficial do líquido resulta em duas regiões lineares, cuja intersecção fornece a velocidade mínima de fluidificação.

Briens et al. (1997a) adota em seu trabalho a definição "fundamentada", ou seja, aquela que diz que a mistura apresenta propriedades macroscópicas de um fluido homogêneo, para caracterizar claramente as transições no regime de escoamento. Para tanto, um sistema experimental foi desenvolvido e foram obtidas informações a partir de uma variedade de medidas, além da quedas de pressão e de observações visuais. 
Tabela 3.6 - Resumo da literatura de velocidade de mínima fluidificação.

\begin{tabular}{|c|c|c|c|c|c|}
\hline Referência & $\begin{array}{c}\text { Técnica } \\
\text { Experimental }\end{array}$ & Partículas & $\begin{array}{c}d_{p} \text { ou } d_{e} \\
(m m)\end{array}$ & Líquido & Gás \\
\hline $\begin{array}{c}\text { BEGOVITCH } \\
\text { \& WATSON } \\
(1978)\end{array}$ & $\begin{array}{r}\text { queda de } \\
\text { pressão }\end{array}$ & $\begin{array}{c}\text { alumina } \\
\text { alumino-silicato } \\
\text { vidro plástico } \\
\text { vidro plástico }\end{array}$ & $\begin{array}{c}6,2 \\
1,9 \\
6,3 \\
4,6 ; 6,2\end{array}$ & água & ar \\
\hline $\begin{array}{c}\text { COSTA et al. } \\
\text { et al. } \\
(1986)\end{array}$ & $\begin{array}{c}\text { pressão p/ achar } \\
\text { altura do leito }\end{array}$ & $\begin{array}{l}\text { vidro, alumina } \\
\text { ácido benzóico } \\
\text { coberto com } \\
\text { película }\end{array}$ & $\begin{array}{c}3-5,9 \\
(\phi=0,87-1)\end{array}$ & $\begin{array}{c}\text { água } \\
\text { CMC } \\
\text { soluções }\end{array}$ & $\begin{array}{c}\mathrm{ar} \\
\mathrm{CO}_{2} \\
\mathrm{He} \\
\mathrm{Me}\end{array}$ \\
\hline $\begin{array}{l}\text { JEAN } \\
(1988)\end{array}$ & $\begin{array}{l}\text { gradientes } \\
\text { de pressão }\end{array}$ & vidro & $\begin{array}{c}0,330 ; 0,460 \\
0,778 ; 1,0 ; 3,04 \\
3,99 ; 6,11\end{array}$ & água & ar \\
\hline $\begin{array}{l}\text { SONG } \\
\text { et al. } \\
(1989)\end{array}$ & $\begin{array}{c}\text { queda } \\
\text { de } \\
\text { pressão }\end{array}$ & catalíticas & $\begin{array}{l}1,67(\phi=0,72) \\
1,85(\phi=0,69) \\
1,56(\phi=0,78) \\
1,51(\phi=0,75) \\
1,69(\phi=0,71) \\
1,57(\phi=0,74) \\
1,90(\phi=0,68)\end{array}$ & $\begin{array}{c}\text { água } \\
\text { água }+0,5 \% \\
\text { t-pentanol }\end{array}$ & ar \\
\hline $\begin{array}{l}\text { ZHANG } \\
\text { et al. } \\
(1995)\end{array}$ & $\begin{array}{l}\text { gradientes } \\
\text { de } \\
\text { pressão }\end{array}$ & $\begin{array}{c}\text { areia } \\
\text { esferas aço } \\
\text { vidro recoberto } \\
\text { vidro } \\
\text { vidro }\end{array}$ & $\begin{array}{c}2,4(\phi=0,8) \\
1,2 \\
2,5 \\
1,5 ; 2,5 \\
3,7 ; 4,5\end{array}$ & água & ar \\
\hline $\begin{array}{c}\text { ERMAKOVA } \\
\text { et al. } \\
(1970)\end{array}$ & visual & vidro & $0,6-2,0$ & $\begin{array}{c}\text { água } \\
\text { água }+15 \% \\
\text { glicerina } \\
\text { água }+50 \% \text { glic. }\end{array}$ & ar \\
\hline $\begin{array}{c}\text { FORTIN } \\
(1984)\end{array}$ & visual & $\begin{array}{c}\text { alumina } \\
\text { alumina } \\
\text { alumina } \\
\text { alumina+Ce }\end{array}$ & $\begin{array}{c}1,6-2,84 \\
2,0(\phi=0,78) \\
1,8(\phi=0,82) \\
1,66\end{array}$ & ciclohexano & $\mathrm{N}_{2}$ \\
\hline $\begin{array}{c}\text { LEE \& } \\
\text { DABBAGH (1978) }\end{array}$ & visual & vidro & 4,$03 ; 6,08$ & & \\
\hline $\begin{array}{r}\text { NACEF } \\
(1991)\end{array}$ & visual & $\begin{array}{l}\text { polipropileno } \\
\text { polipropileno } \\
\text { vidro }\end{array}$ & $\begin{array}{c}2,1(\phi=0,82) \\
3,1(\phi=0,87) \\
1,2 ; 2,0 ; 3,1 ; 4,0\end{array}$ & $\begin{array}{c}\text { água } \\
\text { água }+0,5 \% \text { et. } \\
\text { água }+1,0 \% \text { et. } \\
\text { água }+2,0 \% \text { et. } \\
\text { água }+64 \mathrm{~g} / \mathrm{L} \mathrm{NaCl} \\
\text { água }+0,5 \% \text { n-pent. } \\
\text { água }+1,0 \% \text { n-pent. } \\
\text { água }+0,5 \% \text { t-pent. } \\
\text { água }+1,0 \% \text { t-pent. } \\
\text { percloroetileno }\end{array}$ & $\mathrm{N}_{2}$ \\
\hline $\begin{array}{c}\text { SABERIAN - } \\
\text { BROUDJENNI } \\
(1987)\end{array}$ & visual & $\begin{array}{c}\text { alumina } \\
\text { alumina } \\
\text { alumina } \\
\text { alumina } \\
\text { alumina } \\
\text { vidro }\end{array}$ & $\begin{array}{c}1,74 \\
1,87 \\
2,55 \\
2,0(\phi=0,71-0,78) \\
1,8(\phi=0,82) \\
1,37 ; 3,18\end{array}$ & $\begin{array}{c}\text { água } \\
\text { querosene } \\
\text { ciclohexano } \\
\text { óleo gasoso } \\
\mathrm{C}_{2} \mathrm{Cl}_{4}\end{array}$ & $\begin{array}{l}\mathrm{CO}_{2} \\
\mathrm{He} \\
\mathrm{N}_{2}\end{array}$ \\
\hline $\begin{array}{c}\text { SABERIAN - } \\
\text { BROUDJENNI } \\
(1984)\end{array}$ & visual & $\begin{array}{c}\text { alumina } \\
\text { alumina } \\
\text { vidro }\end{array}$ & $\begin{array}{c}2,55 ; 2,9 \\
2,15(\phi=0,87) \\
1,37 ; 3,18\end{array}$ & $\begin{array}{c}\text { água } \\
\text { querosene } \\
\text { ciclohexano } \\
\mathrm{C}_{2} \mathrm{Cl}_{4}\end{array}$ & $\begin{array}{c}\mathrm{CO}_{2} \\
\mathrm{He} \\
\mathrm{N}_{2}\end{array}$ \\
\hline
\end{tabular}

Obs: $d_{p}$ - diâmetro da partícula $\quad d_{e}-$ diâmetro efetivo da partícula

Fonte: Briens et al. (1997a) 
Dentre as observações, os pesquisadores identificam dois comportamentos distintos na região de leito fixo: leito compactado e leito agitado. À medida que a velocidade ascensional foi aumentada, observou-se que as partículas entraram em processo de agitação, porém sem qualquer deslocamento relativo.

Além disso, os autores ainda identificaram técnicas simples e confiáveis para a determinação da velocidade mínima de fluidificação em um sistema trifásico, com ênfase especial em técnicas adequadas a unidades em escala piloto e industrial. O sistema experimental apresentado na Figura 3.15 consistiu em um reator de leito fluidificado com 2 metros de altura e 0,1 metro de diâmetro tendo como recheio esferas de vidro com $3 \mathrm{~mm}$ de diâmetro, alimentado com uma solução $1 \%$ de $\mathrm{Na}_{2} \mathrm{HPO}_{4}$ mantida a $25^{\circ} \mathrm{C}$.

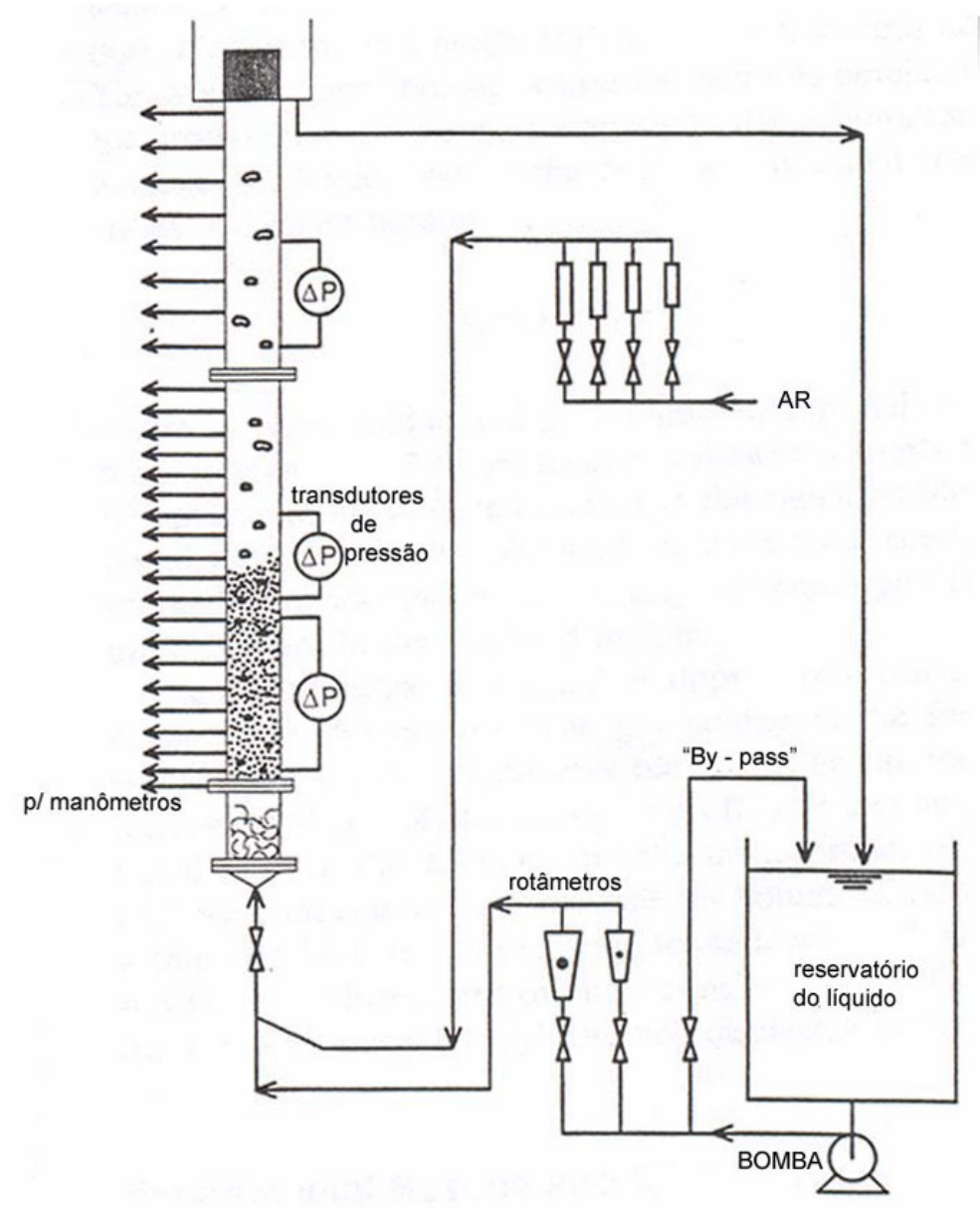

Figura 3.15 - Sistema experimental do reator de leito fluidificado utilizado por Briens et al. (1997a).

Fonte: Briens et al. (1997a) 
Para cada velocidade superficial do líquido foram medidas a expansão do leito, a condutividade elétrica (para medida do "holdup") e as diferenças de pressão, através de manômetros ligados aos 28 pontos distribuídos ao longo da altura do reator. Além disso, transdutores de pressão foram alocados em posições definidas permitindo a determinação do gradiente no interior do leito, na superfície, e dentro da região conhecida como "free board".

Para a verificação das velocidades de fluidificação, os autores calcularam os "holdups" $(\varepsilon)$ das fases. Não há uma tradução prática para o português da palavra "holdup", e muitos autores preferem manter em seus trabalhos a palavra em inglês (Silva, 1995). De qualquer maneira, o "holdup" pode ser definido como a fração volumétrica, um adimensional que quantifica a participação de uma determinada fase (gasosa, líquida ou sólida) na mistura. Para cada velocidade ascensional foram calculados os "holdups", que somados totalizam o valor unitário, ou seja:

$$
\varepsilon_{\mathrm{G}}+\varepsilon_{\mathrm{L}}+\varepsilon_{\mathrm{S}}=1
$$

Na qual:

$\varepsilon_{\mathrm{G}}$ : "holdup" da fase gasosa;

$\varepsilon_{\mathrm{L}}$ : "holdup" da fase líquida;

$\varepsilon_{S}$ : "holdup" da fase sólida.

O "holdup" da fase sólida é obtido através da massa de sólidos introduzidos na coluna e da altura do leito:

$$
\varepsilon_{\mathrm{S}}=\frac{4 \cdot \mathrm{M}_{\mathrm{s}}}{\rho_{\mathrm{p}} \cdot \pi \cdot \mathrm{D}_{\mathrm{c}}^{2} \mathrm{H}_{\text {leito }}}
$$

Na qual:

$\mathrm{D}_{\mathrm{c}}$ : Diâmetro da coluna do reator $(\mathrm{cm})$;

$\mathrm{M}_{\mathrm{s}}$ : Massa de sólidos (g);

$\mathrm{H}_{\text {leito }}$ : Altura do leito (cm);

$\rho_{\mathrm{p}}$ : densidade da partícula $\left(\mathrm{g} / \mathrm{cm}^{3}\right)$; 
O "holdup" da fase líquida foi obtido por um método baseado na condutividade elétrica, o qual necessita de uma calibração prévia. Na Figura 3.16 tem-se um gráfico do "holdup" do líquido em função de sua velocidade, para uma velocidade superficial de gás de $6 \mathrm{~cm} / \mathrm{s}$ :

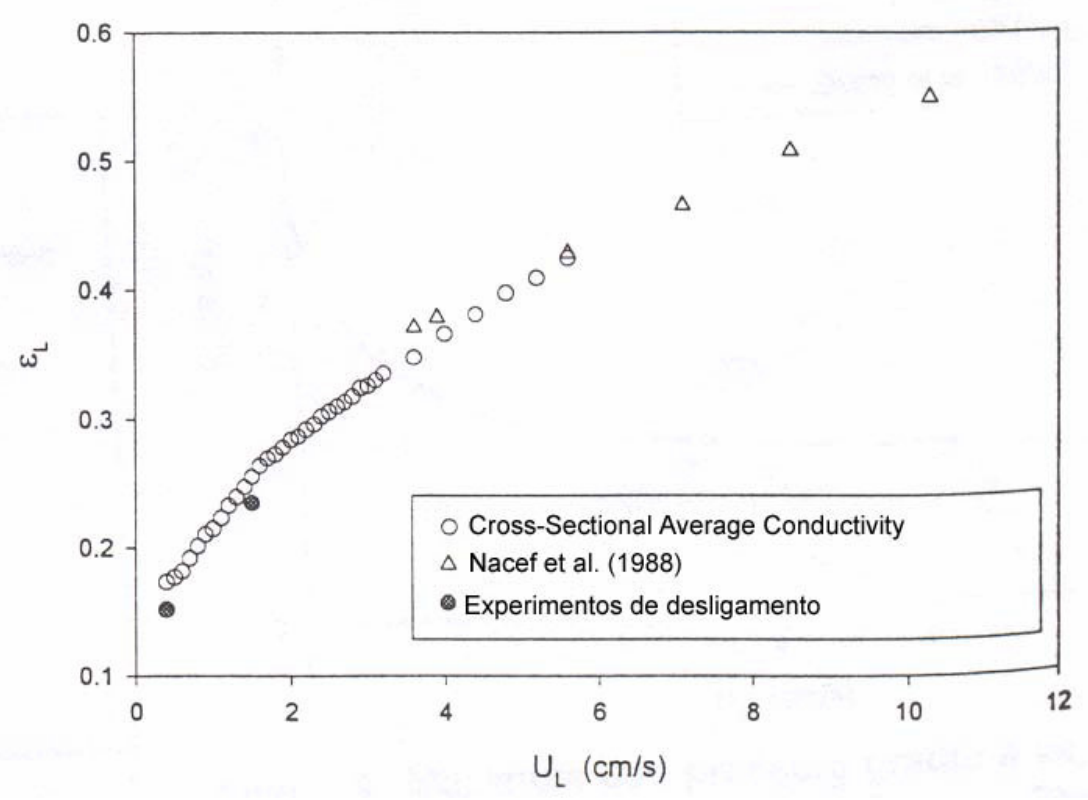

Figura 3.16 - "holdup" da fase líquida para uma velocidade superficial de gás de $6 \mathrm{~cm} / \mathrm{s}$ em um reator de leito fluidificado trifásico, de acordo com três métodos diferentes (BRIENS et al., 1997a).

Fonte: Briens et al. (1997a)

Os autores partiram então do princípio de que o leito está fluidificado quando o gradiente de pressão se iguala ao produto da densidade do leito pela aceleração da gravidade:

$$
\left(-\frac{\Delta \mathrm{P}}{\Delta \mathrm{z}}\right)_{\text {leito }}=\rho_{\text {leito }} \cdot \mathrm{g}
$$

Na qual:

$\left(-\frac{\Delta \mathrm{P}}{\Delta \mathrm{z}}\right)_{\text {leito }}$ : Gradiente de pressão no leito $(\mathrm{Pa} / \mathrm{m})$;

$\rho_{\text {leito }}:$ densidade do leito $\left(\mathrm{Kg} / \mathrm{m}^{3}\right)$;

$\mathrm{g}$ : aceleração da gravidade $\left(\mathrm{m} / \mathrm{s}^{2}\right)$. 
Os "holdups", que foram descritos anteriormente, são utilizados justamente no cálculo da densidade do leito, de acordo com a seguinte expressão:

$$
\rho_{\text {leito }}=\left(\rho_{\mathrm{L}} \cdot \varepsilon_{\mathrm{L}}+\rho_{\mathrm{p}} \cdot \varepsilon_{\mathrm{s}}\right)
$$

Na qual:

$\rho_{\text {leito }}$ : densidade do leito;

$\rho_{\mathrm{L}}$ : densidade do líquido;

$\rho_{\mathrm{p}}:$ densidade da partícula;

Valores dos gradientes de pressão obtidos e da densidade do leito foram colocados em um gráfico em função da velocidade superficial de líquido, e o resultado pode ser verificado na Figura 3.17. As regiões no gráfico confirmaram as observações visuais dos autores, com clara distinção entre a região de leito compactado ( $U_{\mathrm{L}}$ próximo a $0,9 \mathrm{~cm} / \mathrm{s}$ ), a região de leito agitado (ambas regiões de leito fixo) e a região de leito fluidificado $\left(U_{L}>2,5 \mathrm{~cm} / \mathrm{s}\right)$. Porém não se tem um valor acurado para a velocidade de mínima fluidificação, e sim uma idéia da região.

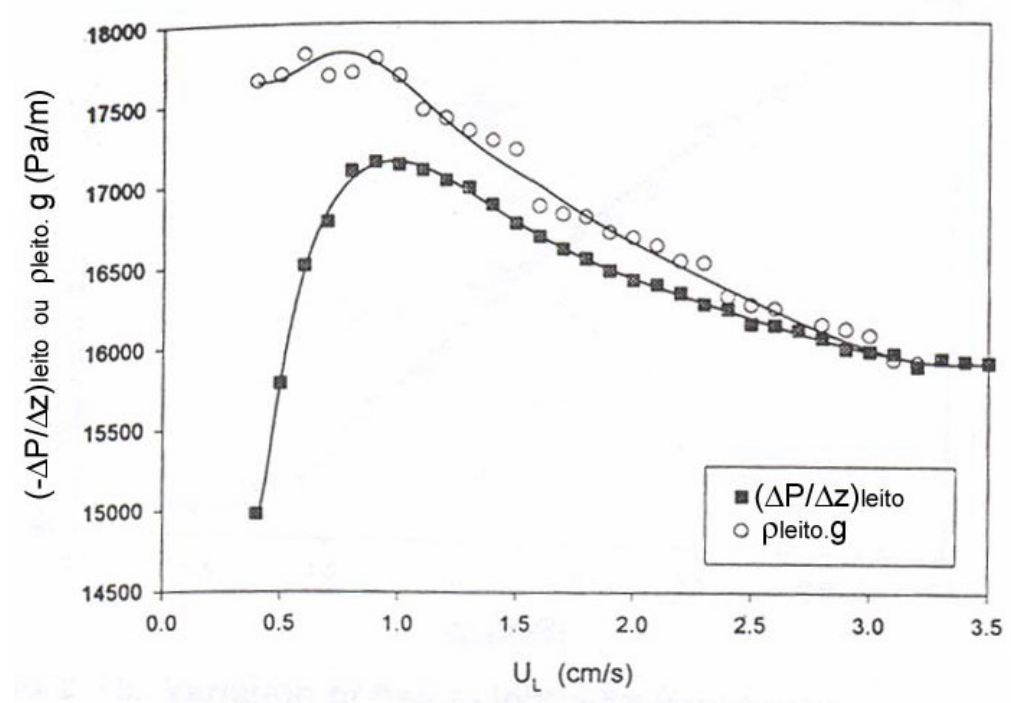

Figura 3.17 - Gradientes de pressão e densidade do leito em função da velocidade superficial do líquido em um reator de leito fluidificado trifásico (BRIENS et al., 1997a).

Fonte: Briens et al. (1997a) 
Em experimentos considerando o sistema bifásico, ou seja, sem a introdução de gás, foram obtidos os pontos de gradiente de pressão dentro do leito em função da velocidade superficial do líquido, e o gráfico apresentou duas regiões lineares, cuja intersecção forneceu a velocidade mínima de fluidificação, correspondente a $3,5 \mathrm{~cm} / \mathrm{s}$, ou $126 \mathrm{~m} / \mathrm{h}$. como pode ser observado na Figura 3.18:

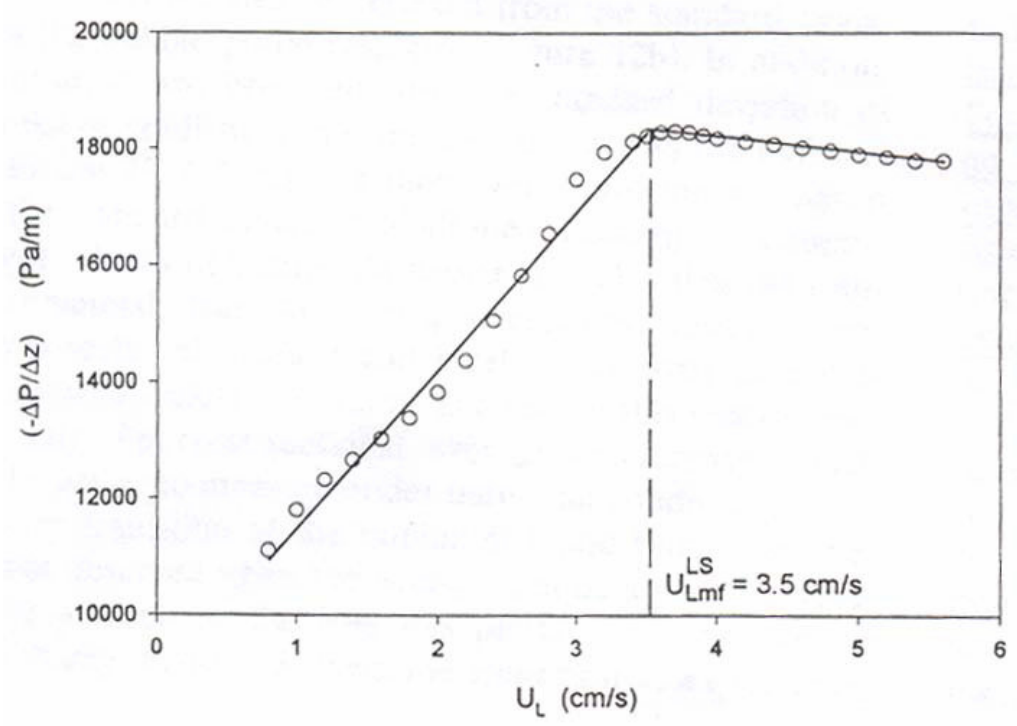

Figura 3.18 - Velocidade mínima de fluidificação em um reator de leito fluidificado bifásico líquido-sólido (BRIENS et al., 1997a).

Fonte: Briens et al. (1997a)

Dentre as principais verificações, os autores concluíram que o sistema apresenta três regimes de escoamento à medida que a velocidade superficial do líquido é aumentada, e que o leito não está fluidificado no regime agitado. Afirmam ainda que em leitos trifásicos, a medida do gradiente de pressão e da expansão do leito não fornece um valor acurado para a velocidade mínima de fluidificação, mas sim as regiões entre os três regimes de escoamento, e que esta velocidade mínima decresce com a introdução do gás.

Em outro trabalho, Briens et al. (1997b) observam que a maioria dos estudos em sistemas trifásicos é realizada com sólidos cuja densidade é no mínimo duas vezes a densidade do líquido (Song et al., 1989; Zhang et al., 1995), mas salientam que em uma grande parcela de processos trifásicos biológicos, que utilizam células imobilizadas, a densidade dessas partículas é 
apenas ligeiramente maior que a densidade do líquido, e nesses processos, as propriedades das fases não permanecem idênticas, já que as células imobilizadas consomem gases dissolvidos e nutrientes e produzem gases e produtos. Sendo assim, a densidade aparente da partícula pode também decrescer quando os subprodutos gasosos são capturados pela matriz imobilizada.

Briens et al. (1997b), em uma montagem experimental similar a Briens et al. (1997a), identificaram técnicas de medida "on-line" para a velocidade de mínima fluidificação em um sistema trifásico com partículas de baixa densidade.

Ainda com o intuito de se estudar a fluidodinâmica de reatores biológicos em condições que representem melhor a realidade, Miura e Kawase (1998) estudaram a velocidade mínima de fluidificação em leitos fluidificados bifásicos e trifásicos utilizando fluidos não newtonianos, que podem ser encontrados em indústrias de processamento de alimento e polímeros, e de biotecnologia.

Verificaram que a velocidade de mínima fluidificação decresceu com o aumento da velocidade do gás, mas que a magnitude desse decréscimo foi menor se comparado à diminuição do tamanho da partícula. Também notaram que a velocidade decresce com o aumento da viscosidade do fluido nãonewtoniano.

Os autores desenvolveram uma correlação da velocidade de mínima fluidificação para fluidos não newtonianos em sistemas bifásicos, que pode ser aplicada para uma ampla região de números de Reynolds. Os autores afirmam ainda que "esse estudo deve ser observado como um primeiro esforço para se entender escoamento não-newtoniano em leitos fluidificados trifásicos".

Asif e Ibrahim (2002) estudaram a velocidade mínima de fluidificação em um sistema bifásico, com a peculiaridade de a fase sólida ser binária, ou seja, possuir partículas com dois materiais e características diferentes. Os autores argumentaram que esse tipo de situação pode ajudar a alterar as características fluidodinâmicas básicas de um leito fluidificado pela adição de uma outra fase sólida, que tem diferentes propriedades físicas em relação a fase residente. De fato, Yang e Renken (1998) ${ }^{3}$ apud Asif e Ibrahim (2002)

\footnotetext{
${ }^{3}$ Yang, J. e Renken, A. (1998). Chem. Eng. Process., v. 37, 537-544.
} 
mostraram que ocorre um aumento na transferência de massa pela adição de pequenas e densas partículas inertes de vidro em um leito fluidificado contendo partículas ativas de resina.

Cerca de cinco conjuntos binários foram considerados para o estudo, com diferentes combinações de tamanhos e densidades. Verificou-se que na medida que a razão de tamanho era diminuída havia um aumento na tendência de segregação para binários com substanciais diferenças em suas densidades. Para os binários com as maiores razões de tamanho, notou-se a completa absorção dos componentes menores pela matriz dos componentes maiores. Claramente a adição de partículas pequenas e com grande densidade pode abaixar consideravelmente a velocidade de mínima fluidificação em leitos com partículas maiores. Porém, a composição do leito precisa ser cuidadosamente controlada quando a razão de tamanho for superior a 6,5.

A utilização apenas de partículas inertes, entretanto, não deixa de ser um procedimento incompleto em estudos fluidodinâmicos que queiram representar com mais fidelidade a operação de leitos fluidificados trifásicos biológicos. Principalmente pelo fato da presença de biomassa (tanto livre quanto imobilizada) proporcionar características novas para a fluidodinâmica do sistema, é interessante que sejam realizados estudos fluidodinâmicos também voltados para as combinações híbridas, e que levem em conta a interação partícula / biomassa. Freire (2000) afirma que estudos mais específicos do conjunto biofilme / suporte como, por exemplo, a influência da fluidodinâmica no cisalhamento do biofilme, ainda são necessários, principalmente em materiais de alta porosidade.

A quantidade de trabalhos encontrados na literatura que de alguma forma levam em consideração a influência da biomassa no comportamento dinâmico do leito é bem inferior aos estudos com partículas inertes. DiezBlanco et al. (1995) afirmam que as bactérias que realizam a digestão anaeróbia de águas residuárias, aderidas às pequenas partículas, modificam sua densidade, tamanho e forma, e, portanto, o comportamento fluidodinâmico. Isto implica que para manter uma expansão do leito pré-fixada, é necessário alterar a recirculação.

Segundo os autores, uma das variáveis mais importantes em um RALF é a expansão do leito, já que ela estabelece o tempo de residência da matéria 
orgânica na região reativa, e está diretamente relacionada ao processo de bombeamento. Os pesquisadores verificaram os efeitos do crescimento do biofilme e da produção de gás na expansão do leito de um RALF tendo a sepiolita como material suporte, uma argila fibrosa com superfície porosa e não estritamente uniforme, devido a sua origem natural. De coloração branca, cinza-clara ou amarelo-clara, extremamente leve, absorvente e compacta, ela é encontrada especialmente na Ásia. O diâmetro de partícula utilizado estava situado entre 0,425 e $0,500 \mathrm{~mm}$.

A instalação experimental (Figura 3.19) consistia de um reator de leito fluidificado com 2 metros de altura e 0,19 metros de diâmetro, com seis amostradores distribuídos ao longo da altura.

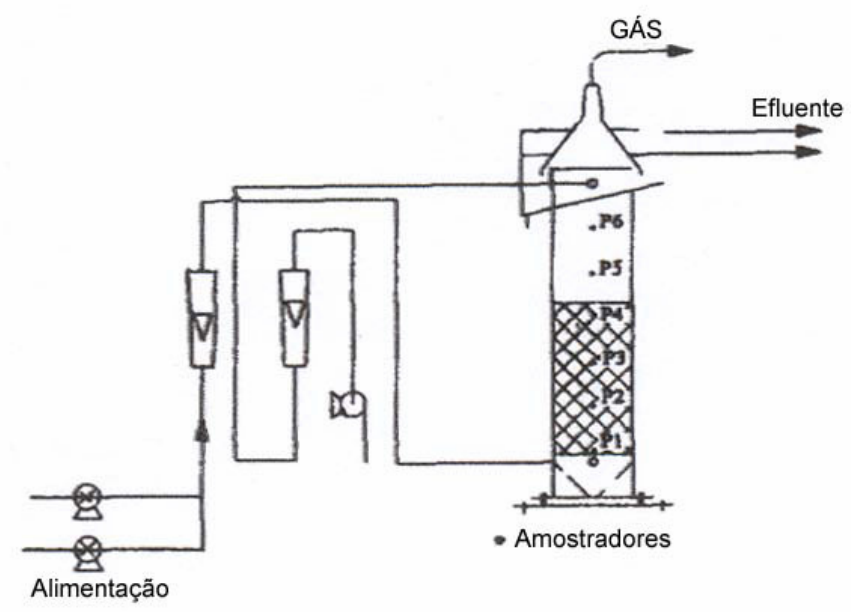

Figura 3.19 - RALF utilizado por Diez-Blanco et al. (1995) para experimentos fluidodinâmicos.

Fonte: Diez-Blanco et al. (1995)

O reator foi alimentado com um efluente sintético contendo ácido acético, álcalis e nutrientes, e as condições operacionais são mostradas na Tabela 3.7.

Periodicamente, amostras de partículas com biomassa imobilizada foram coletadas ao longo dos diferentes amostradores para diversas análises e cálculos, dentre eles sólidos voláteis, densidade aparente do leito, volume relativo do biofilme, espessura relativa e umidade. Para cada fase, 0 
desenvolvimento do biofilme foi monitorado pelo crescimento dos sólidos voláteis.

Tabela 3.7 - Fases e parâmetros de operação do RALF utilizado por DiezBlanco et al. (1995).

\begin{tabular}{|c|c|c|}
\hline FASE & $\frac{\text { Carga orgânica }}{(a)}$ & $\frac{\theta_{\mathrm{h}}}{(\mathrm{hcl})}$ \\
\hline 1 & 2 & 18 \\
\hline II & 5 & 11 \\
\hline III & 10 & 7 \\
\hline IV & 21 & 4 \\
\hline V & 35 & 5 \\
\hline
\end{tabular}

Fonte: Diez-Blanco et al. (1995)

Diez-Blanco et al. (1995) observaram que embora esse tipo de reator anaeróbio seja notadamente trifásico, ele pode ser estudado como leito fluidificado bifásico clássico, introduzindo-se o biogás como uma correção do comportamento fluidodinâmico previsto. Então os autores consideraram desprezível o biogás retido no biofilme, e verificaram o comportamento do leito para 4 diferentes velocidades ascensionais de gás introduzidas. Sendo assim, a equação mais comumente utilizada para descrever a relação entre porosidade e velocidade superficial em um leito fluidificado é a equação de Richardson e Zaki (RICHARDSON E ZAKI, 1954):

$$
U_{\infty}=\varepsilon^{n}
$$

Na qual:

U: velocidade relativa fluido-partícula;

$\mathrm{U}_{\infty}$ : velocidade terminal da partícula isolada;

$\varepsilon:$ porosidade do leito;

$\mathrm{n}$ : constante empírica determinada a partir de dados experimentais.

Como resultados, apesar da clara estratificação verificada no leito, que foi comprovada através de análises experimentais, o comportamento 
fluidodinâmico das partículas "limpas" (sem biofilme) foi perfeitamente descrito pela equação 3.6. Para essas partículas, a correlação determinada foi:

$$
U=144 \cdot \varepsilon^{3,57}(\mathrm{~m} / \mathrm{h})
$$

A análise de sólidos voláteis ao longo da altura do reator, para as cinco fases da pesquisa, permitiu a avaliação do crescimento do biofilme. A Figura 3.20 mostra o desenvolvimento do biofilme ao longo do tempo. Analisando a Figura 3.20, e lembrando que P2, P3, P4 e P5 são os amostradores distribuídos ao longo da altura, percebe-se que no topo do reator, e à medida que a carga orgânica foi aumentada, verificou-se um maior crescimento de biofilme, e que no inferior as taxas foram mantidas praticamente constantes com o aumento da carga orgânica.

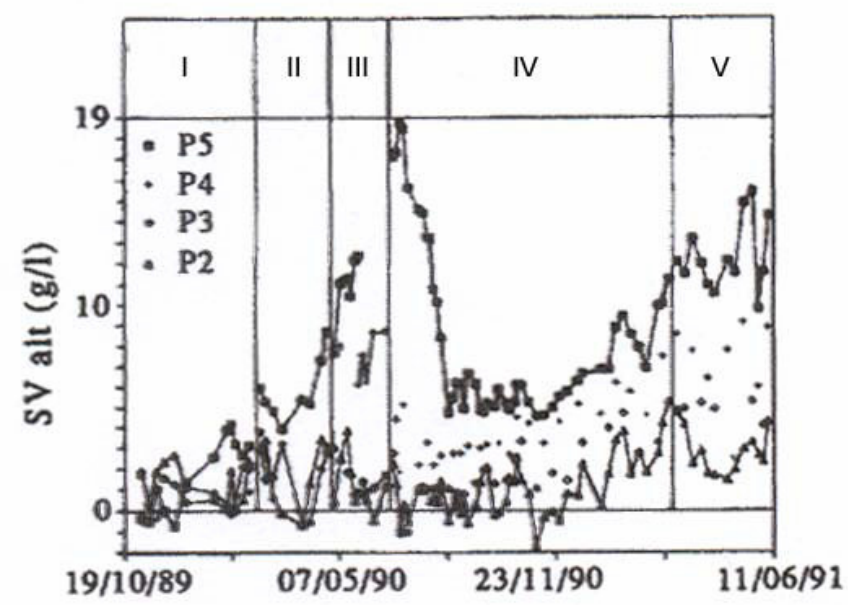

Figura 3.20 - Avaliação do crescimento do biofilme (em termos de concentração de sólidos voláteis) ao longo das fases operacionais, para os diferentes pontos de amostragem do RALF de Diez-Blanco et al. (1995). Fonte: Diez-Blanco et al. (1995)

$\mathrm{Na}$ investigação principal, os autores verificaram que o efeito do biogás foi insignificante no comportamento fluidodinâmico do reator, podendo este ser projetado e operado como um reator bifásico, sem a introdução de grandes erros.

A Figura 3.21 mostra os resultados obtidos para velocidade ascensional do líquido em função da porosidade do leito para as 5 fases de operação, cada 
uma com distintas características de partícula. Para efeito de comparação também foi acrescentado o resultado para a fluidificação com a partícula sem biofilme.

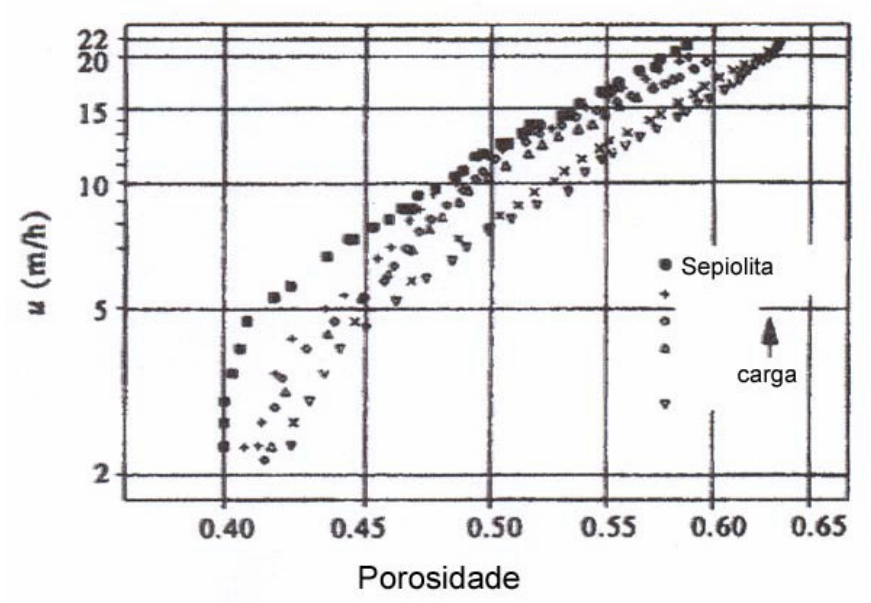

Figura 3.21 - Velocidades ascensionais em função da porosidade para diferentes cargas orgânicas no experimento de Diez-Blanco et al. (1995). Fonte: Diez-Blanco et al. (1995)

O crescimento do biofilme produz dois efeitos no comportamento fluidodinâmico:

- a velocidade ascensional de líquido necessária para manter uma mesma expansão de leito (porosidade) decresce, devido à diminuição da densidade da partícula e a diminuição da velocidade terminal, e

- a estratificação do leito aumenta, devido ao crescimento não uniforme do biofilme.

Com exceção da carga orgânica e do tempo de detenção hidráulica, os autores não fornecem maiores informações sobre as condições operacionais aplicadas entre os ensaios de expansão. Assim, não se sabe, por exemplo, se o leito foi mantido em condições únicas de fluidificação.

Somado a isto, é conveniente acrescentar que as conclusões obtidas se referem a uma situação específica, ou seja, partículas de sepiolita com diâmetros menores que $0,5 \mathrm{~mm}$, submetidas a diferentes cargas orgânicas. Muitas investigações complementares são necessárias, inclusive com partículas de material e dimensões diferentes, para que se verifique 0 comportamento em outras condições. 
Segundo os autores, o efeito do crescimento do biofilme na relação entre velocidade ascensional e expansão do leito pode ser avaliado a partir da análise da concentração de sólidos voláteis aderidos ( $\left.S V_{\text {att }}\right)$.

Supondo uma partícula esférica, o diâmetro e a densidade da partícula (com biomassa aderida) podem ser relacionados com a espessura do biofilme

$$
\begin{aligned}
& d_{p}=d_{s}+2 . \delta \\
& \rho_{p}=\rho_{b w}+\left(\rho_{s}-\rho_{b w}\right) \times\left(\frac{d_{s}}{d_{s}+2 . \delta}\right)^{3}
\end{aligned}
$$

Nas quais:

$\mathrm{d}_{\mathrm{p}}$ : diâmetro da partícula (suporte + biofilme);

$\mathrm{d}_{\mathrm{s}}$ : diâmetro do suporte;

$\delta$ : espessura do biofilme;

$\rho_{\mathrm{p}}$ : densidade da partícula (suporte + biofilme);

$\rho_{\mathrm{s}}$ : densidade da partícula inerte;

$\rho_{\text {bw: }}$ densidade do biofilme "molhado";

A espessura do biofilme, por sua vez, está relacionada com os sólidos voláteis pela seguinte equação:

$$
\delta=\frac{d_{\mathrm{S}}}{2}\left[\frac{1}{\sqrt[3]{1-\frac{\mathrm{SV}_{\mathrm{att}}}{\rho_{\mathrm{bw}}(1-\mathrm{P})\left(1-\varepsilon_{\mathrm{mf}}\right)}}}-1\right]
$$

Na qual:

$\mathrm{SV}_{\text {att: }}$ sólidos voláteis aderidos;

$\mathrm{P}$ : umidade do biofilme;

$\varepsilon_{\mathrm{mf}}$ : porosidade nas condições de fluidificação;

A partir do diâmetro e da densidade da partícula é possível calcular a velocidade terminal da partícula $\left(\cup_{\mathrm{t}}\right)$ : 


$$
u_{t}=\sqrt[2-k]{\frac{4 \cdot g}{3 \cdot b} \frac{\left(\rho_{p}-\rho\right) \cdot d_{p}^{1+k}}{\rho^{1-k} \mu^{k}}}
$$

Os parâmetros b e k são constantes da equação 3.11, e foram determinados por vários autores para diferentes tipos de biopartículas e diferentes regimes de sedimentação.

Dessa maneira, através das condições experimentais específicas e de valores apresentados na literatura, é possível prever o comportamento fluidodinâmico para diferentes concentrações de sólidos voláteis aderidos, usando a equação de Richardson e Zaki. Empregando este equacionamento, os autores chegaram a um gráfico de velocidade ascensional em função da porosidade, para concentrações teóricas de sólidos voláteis. Esse gráfico (Figura 3.22) é muito semelhante ao que foi obtido experimentalmente, relacionando a velocidade ascensional com a porosidade, para as diferentes cargas orgânicas aplicadas (Figura 3.21). Segundo os autores, para expansões do leito maiores que $20 \%$, a determinação teórica fornece uma boa estimativa do comportamento do RALF.

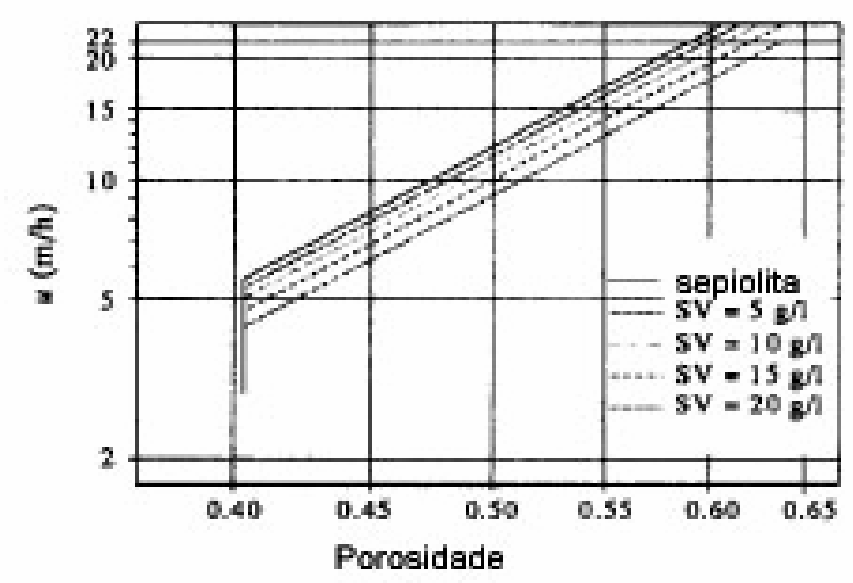

Figura 3.22 - Velocidades ascensionais em função da porosidade, previstas para diferentes cargas orgânicas (teóricas) em equacionamento apresentado por Diez-Blanco et al. (1995).

Fonte: Diez-Blanco et al. (1995) 
Buffière et al (1998) concordam com a constatação de Diez-Blanco et al. (1995) que a presença de gás dificilmente modifica as características de expansão do leito, porém ressalvam que o efeito da fase gasosa em reatores anaeróbios pode ser significativo na dispersão líquida ${ }^{4}$ e no cálculo dos "holdups". Os pesquisadores afirmam que os parâmetros mais importantes, no caso de um reator anaeróbio com produção de gás, são os seguintes: regime de escoamento do gás, "holdups" das fases e a dispersão do líquido.

Em uma revisão elaborada, os autores indicam que em leitos fluidificados trifásicos o regime de escoamento do gás pode ser tanto do tipo "junção de bolhas" (com partículas densas, pequenas e a baixas velocidades de líquido), como o regime de "bolhas dispersas" (com partículas grandes e elevadas velocidades do líquido). O gás introduzido no sistema freqüentemente provoca uma contração inicial na altura do leito, sendo este efeito mais significativo com baixas vazões de gás e pequenas partículas (menores que $1,0 \mathrm{~mm}$ ). Em leitos com partículas maiores, esse efeito é desprezível. Os pesquisadores explicam o efeito de contração do leito através do modelo das esteiras proposto inicialmente por Stewart e Davidson $(1964)^{5}$ apud Buffière et al. (1998).

Quanto à dispersão do líquido, ela pode ser desprezível em leitos com partículas grandes (maiores que $6 \mathrm{~mm}$ ), mas o efeito é muito importante em leitos com partículas com diâmetro na faixa de $1 \mathrm{~mm}$, como é o caso de biorreatores trifásicos em escala industrial tratando águas residuárias, que geralmente possuem partículas com tamanhos entre 0,2 e 1,0 mm. Esse tamanho é utilizado com a finalidade de maximizar as áreas de transferência e minimizar os custos com a fluidificação. Nesses casos, a velocidade do líquido fica na faixa de 5 a $30 \mathrm{~m} / \mathrm{h}(0,13$ a $0,83 \mathrm{~cm} / \mathrm{s})$.

$\mathrm{Na}$ digestão anaeróbia, o gás produzido em um reator com, por exemplo, $1,0 \mathrm{~m}$ de diâmetro e 6,0 metros de altura, tratando $50 \mathrm{~kg} \mathrm{DQO} / \mathrm{m}^{3}$.dia, pode chegar a uma vazão de $140 \mathrm{~m}^{3} / \mathrm{dia}$, com uma velocidade de $7,5 \mathrm{~m} / \mathrm{h}$ ou 0,21 $\mathrm{cm} / \mathrm{s}$. De um modo geral, a velocidade do gás depende da sua produção volumétrica e é proporcional à altura do reator.

\footnotetext{
${ }_{5}^{4}$ Do inglês "liquid mixing".

${ }^{5}$ Stewart, P. e Davidson, J. (1964). Three-phase fluidization: water, particles anda ir. Chem. Engng Sci. v. 19, 319-322.
} 
Buffière et al. (1998) afirmam que até aquela data, não existiam na literatura trabalhos práticos com base em dados experimentais para determinação precisa dos "holdups", do coeficiente de dispersão e também sobre a estrutura do escoamento do líquido em biorreatores trifásicos. Com essa motivação, os autores elaboraram um experimento em um reator trifásico, com $115 \mathrm{~mm}$ de diâmetro e $1,5 \mathrm{~m}$ de altura. O interessante é que o estudo não foi realizado diretamente em um reator biológico. Ou seja, a introdução do gás, conseguida através de uma reação química entre soluções de ácido sulfúrico e bicarbonato de sódio, resultando na produção de $\mathrm{CO}_{2}$, foi feita para simular as condições de um biorreator. Como "recheio" do leito foram utilizadas partículas de biolita $\left(d_{p}=0,28 \mathrm{~mm}\right)$ ou de pozzolana $\left(d_{p}=0,38 \mathrm{~mm}\right)$, uma rocha vulcânica.

Os "holdups" foram determinados pelo método "clássico" dos gradientes de pressão, ou seja, onde se utiliza a determinação experimental da altura do leito e o gradiente de pressão relativo a essa altura.

$$
\begin{aligned}
& \frac{d P}{d z}=-g \cdot\left(\varepsilon_{s} \rho_{s}+\varepsilon_{L} \rho_{L}+\varepsilon_{G} \rho_{G}\right) \\
& \varepsilon_{S}+\varepsilon_{L}+\varepsilon_{g}=1 \\
& \varepsilon_{S}=\frac{M}{\rho_{S} \cdot H \cdot A}
\end{aligned}
$$

Conhecendo-se $\rho_{\mathrm{s}}, \rho_{\mathrm{L}}$ e $\rho_{\mathrm{g}}$, a massa de sólidos no reator $\left(\mathrm{M}_{\mathrm{s}}\right)$ e a área da secção transversal $(A)$, basta determinar experimentalmente a altura do leito fluidificado $(H)$ e o gradiente de pressão $(\mathrm{dP} / \mathrm{dz})$ referente a essa altura $H$, que o sistema ficará então com 3 equações e 3 incógnitas, e finalmente são obtidos os "holdups".

Como se observa, os leitos fluidificados bifásicos e trifásicos são extensivamente pesquisados e utilizados em uma ampla gama de aplicações. Entretanto um dos maiores problemas, que continua a limitar sua aplicação industrial, está relacionado à dificuldade no aumento de escala, ou seja, transportar resultados obtidos com pequenos experimentos para grandes unidades industriais. Em pequenas unidades de teste, freqüentemente os 
resultados são obtidos a partir de comportamentos de leito que não podem ser atingidos quando o tamanho do equipamento é aumentado. Uma redução na conversão, ou mesmo a incapacidade de se conseguir rendimentos obtidos em escalas menores pode interferir negativamente na maioria dos processos.

Safoniuk et al. (1999) apresentaram uma nova abordagem para que as surpresas com ampliações de escala fossem prevenidas, e assim tornar pertinentes os resultados obtidos em pequena escala, ao serem convertidos para escalas industriais. Visto que a fluidodinâmica controla o grau de contato entre as fases, um bom entendimento desse tópico é essencial para se eliminar ou minimizar essas surpresas. Tal abordagem consiste em assegurar uma ampliação de escala efetiva da fluidodinâmica do leito, baseada na semelhança dimensional e no teorema Pi de Buckingham, onde um conjunto de parâmetros adimensionais é usado para atingir similaridade dinâmica em leitos fluidificados trifásicos.

Com o conjunto de adimensionais estabelecido, experimentos foram apresentados para validá-los comparando o "holdup" de gás e a expansão do leito para duas colunas com características geométricas diferentes, operando com líquidos e sólidos distintos. Na maior parte essa abordagem mostrou uma boa representação na ampliação de escala, e os autores salientam que pesquisas complementares são necessárias para completar a validação.

Macchi et al. (2001) complementaram a pesquisa de Safoniuk et al. (1999) para testar dois novos sistemas. Como resultado, verificou-se que embora a expansão do leito tenha sido qualitativamente similar, a tendência quantitativa foi diferente, principalmente em elevadas velocidades de gás, e os dois sistemas se adequaram bem à equação de Richardson e Zaki. Uma análise estatística mostrou que houve diferenças entre os dois sistemas, mas que em geral não ultrapassaram os 12\%, mostrando que abordagem de semelhança dimensional fornece uma base razoável para a ampliação de escala de parâmetros fluidodinâmicos.

\subsection{CONSIDERAÇÕES FINAIS DA REVISÃO DA LITERATURA}

A partir de uma idéia inicial, que era a de avaliar o reator anaeróbio de leito fluidificado na remoção do pentaclorofenol de um efluente sintético, o 
estudo da literatura referente ao tema serviu como um importante auxílio na elaboração da metodologia deste trabalho, indicando novos caminhos a serem investigados, outros que ainda são pouco explorados, e finalmente caminhos que, mesmo já utilizados por outros pesquisadores, se apresentaram como testes interessantes para esta situação em particular.

A otimização operacional dos reatores anaeróbios de leito fluidificado só será alcançada mediante $\mathrm{O}$ entendimento em conjunto dos aspectos microbiológicos e dinâmicos. Neste trabalho, as questões fundamentais foram direcionadas para as características do escoamento, que são igualmente importantes pois também comandam a eficiência do sistema. 


\section{MATERIAIS E MÉTODOS}

\subsection{CONSIDERAÇÕES GERAIS}

A metodologia do trabalho foi definida e desenvolvida para cumprir o objetivo proposto, obedecendo 4 grandes etapas programadas:

1) avaliação de 3 "candidatos" a meio suporte através de ensaios de caracterização, de fluidodinâmica e de imobilização de biomassa;

2) análise das seguintes interações:

- partícula (sem e com biomassa imobilizada)/ fluido

- conjunto de partículas (sem e com biomassa imobilizada) / fluido

3) avaliação do desempenho do RALF sem PCP, e

4) avaliação do desempenho do RALF na remoção do PCP,

Com a finalidade de estabelecer uma nomenclatura e simplificar a descrição das etapas, deste ponto em diante as partículas sem biomassa imobilizada serão denominadas de "partículas inertes" e as partículas com biomassa imobilizada serão denominadas "biopartículas". Partículas inertes de três materiais diferentes foram selecionadas como "candidatas" a meio suporte do RALF, segundo critérios que serão descritos posteriormente, e com a finalidade principal de se verificar a viabilidade de utilização desses 3 materiais em reatores biológicos.

O esquema da Figura 4.1 mostra de maneira simplificada o desmembramento das etapas, para uma visualização integrada de todo o trabalho. 


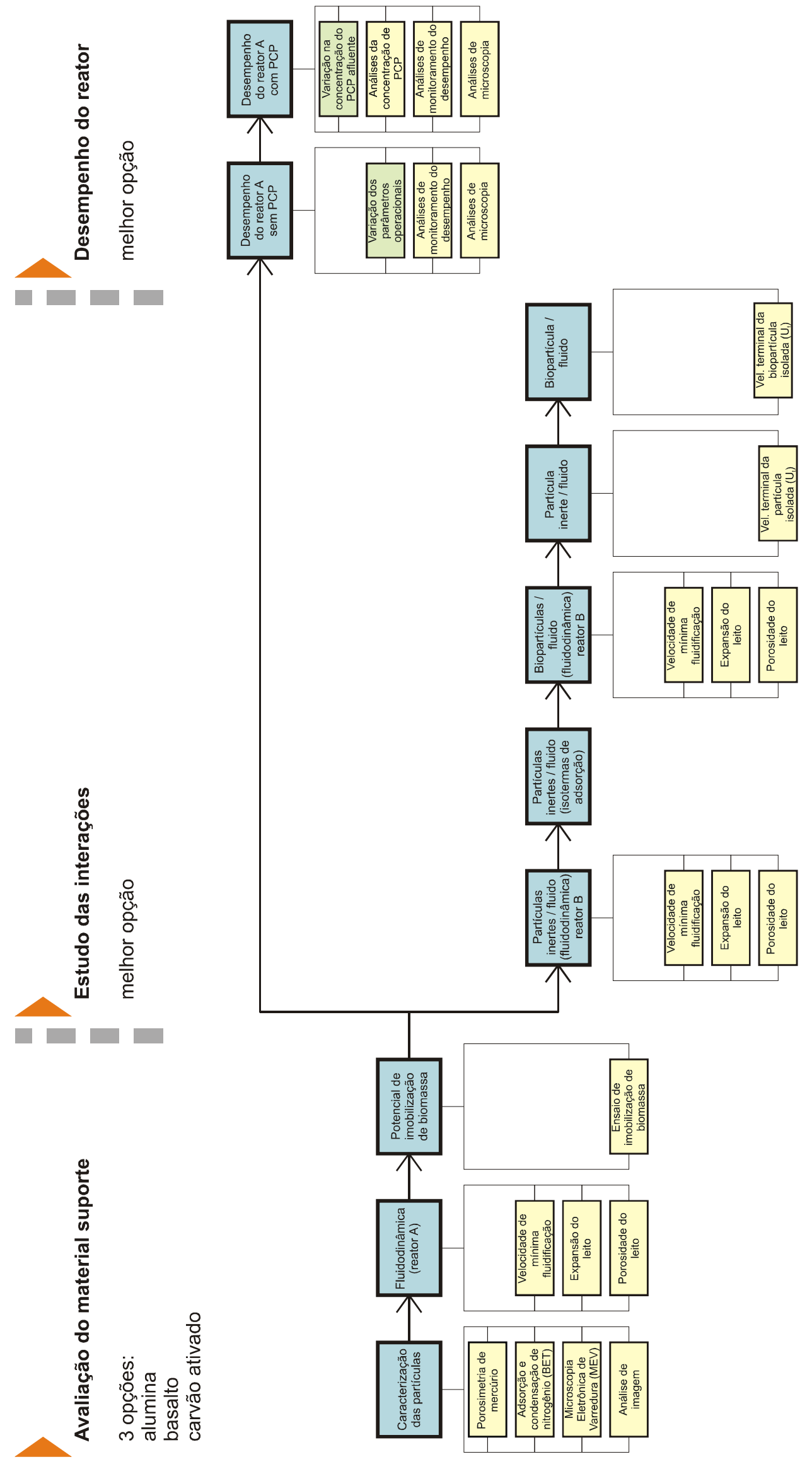

Figura 4.1 - Esquema com todas as etapas da pesquisa. 
É importante esclarecer que as divisões da Figura 4.1 foram feitas segundo critérios temáticos e não necessariamente cronológicos.

Neste capítulo, inicialmente serão descritos alguns materiais e procedimentos experimentais que foram comuns a muitas etapas: partículas para meio suporte de biomassa, lodo de inóculo, efluente, reatores e o processo de inoculação dos reatores. Posteriormente, serão descritas as etapas, de acordo com a ordem esquematizada na Figura 4.1.

\subsection{MATERIAIS E PROCEDIMENTOS COMUNS A VÁRIAS ETAPAS}

\subsubsection{MEIO SUPORTE}

Os materiais "candidatos" escolhidos para avaliação foram: alumina, basalto e carvão ativado.

A alumina foi escolhida por ser um material com elevada porosidade e por sua durabilidade. Por ser originária de um processo industrial com controle de formas e dimensões, ao contrário dos outros dois materiais, ela pode ter uma geometria bem definida, com partículas extremamente similares entre si, facilitando a reprodutibilidade dos ensaios, principalmente os fluidodinâmicos. Neste trabalho especificamente, foram utilizadas partículas de alumina esféricas. A alumina vem sendo constantemente utilizada em pesquisas que analisam a fluidodinâmica de reatores, e também como fase sólida em processos de secagem, mas sua potencialidade como meio suporte biológico ainda necessita de maiores investigações.

O carvão ativado foi escolhido por representar um material de baixa densidade e elevada porosidade. Sua viabilidade como meio suporte em reatores biológicos é comprovada por inúmeros trabalhos da literatura, e sua utilização serve como um "padrão" para comparações, como já foi relatado na revisão deste trabalho. Entretanto, sua aplicação em estudos fluidodinâmicos não foi encontrada na literatura, demonstrando ser este um campo aberto para investigações, até para complementar o conhecimento já adquirido deste material em outros aspectos.

Para facilitar a experimentação, o estudo da fluidodinâmica é feito muitas vezes em condições idealizadas, com partículas esféricas densas e pouco 
porosas (como por exemplo esferas de vidro). Talvez por esse motivo, a utilização do carvão ativado não seja, a princípio, atrativa, já que se trata de uma partícula com elevada porosidade, baixa densidade, e geometria extremamente irregular.

O basalto foi escolhido por representar um material com elevada densidade e baixa porosidade. Sua escolha foi em caráter investigativo, já que sua utilização não foi encontrada na literatura.

A alumina e o basalto utilizados na pesquisa foram adquiridos junto ao Departamento de Engenharia Química da Universidade Federal de São Carlos $^{6}$. A alumina foi produzida na ALCOA Alumínio S.A. e o basalto havia sido adquirido em estabelecimento comercial de materiais de construção (informação verbal) ${ }^{7}$. O carvão ativado vegetal, para emprego original em filtros de piscina, foi adquirido em estabelecimento comercial especializado ${ }^{8}$. As partículas de alumina tinham diâmetro de $3,5 \mathrm{~mm}$ (informação do fabricante) enquanto o basalto e o carvão ativado possuíam diâmetros em extensa faixa granulométrica. Posteriormente eles foram peneirados de acordo com as necessidades.

As faixas granulométricas escolhidas para cada ensaio (e que serão mostradas no capítulo de resultados) foram obtidas através de peneiramento mecânico, utilizando-se peneiras da marca Retsch com várias malhas e peneirador vibratório da marca Retsch (modelo 200 Control USA), configurado para uma amplitude de vibração de $1,5 \mathrm{~mm}$ e 3 minutos de duração do ciclo.

\subsubsection{REATORES ANAERÓBIOS DE LEITO FLUIDIFICADO}

Devido ao elevado número de abordagens, optou-se pelo projeto, construção e desenvolvimento de dois reatores RALF, o reator maior (denominado de reator A) e um reator auxiliar (reator B). O reator A (Figura 4.2a) foi utilizado para a avaliação prévia dos materiais suporte e também como reator biológico nas etapas de avaliação de desempenho (com e sem $\mathrm{PCP}$ ). O reator $\mathrm{B}$ (Figura $4.2 \mathrm{~b}$ ) foi utilizado exclusivamente para ensaios de

\footnotetext{
${ }^{6}$ Material gentilmente cedido pelo Prof. José Teixeira Freire.

${ }^{7}$ Informação dada pessoalmente, pelo referido professor.

${ }^{8}$ Casa das Bombas, em São Carlos - SP.
} 
fluidodinâmica. A idéia central foi de poder trabalhar em paralelo, e dessa maneira, otimizar a pesquisa através de processos simultâneos.

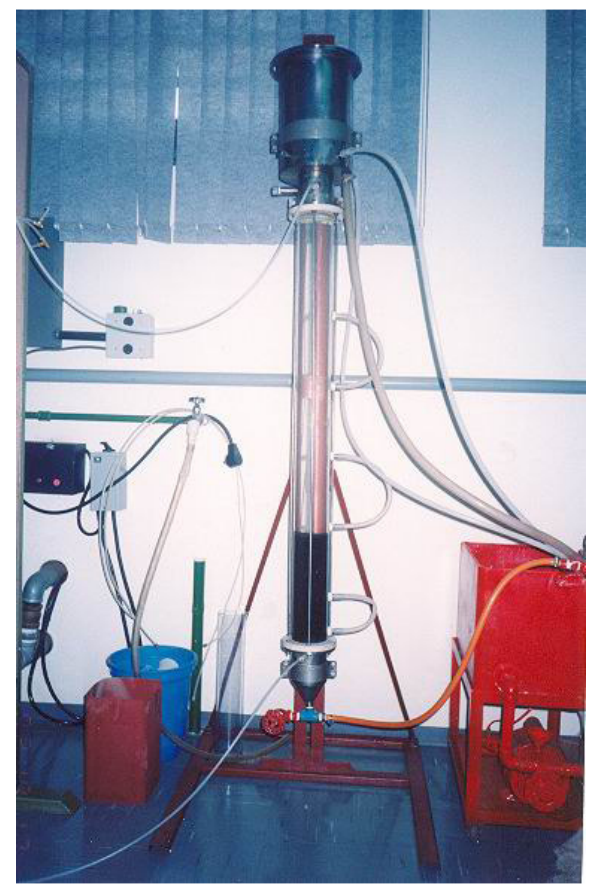

(a)

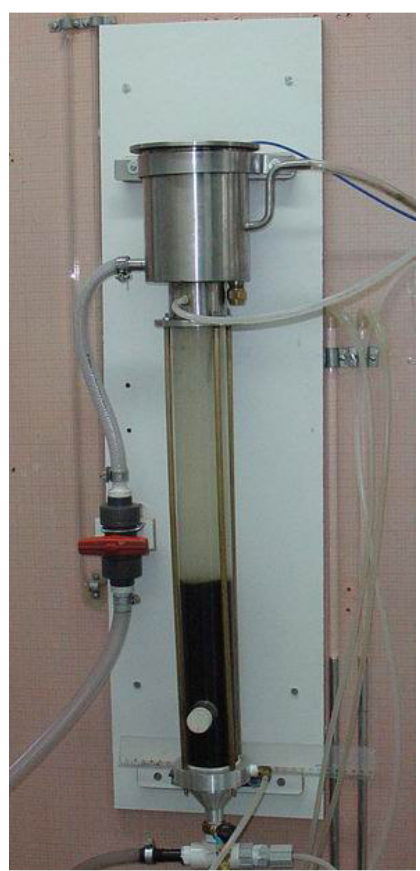

(b)

Figura 4.2 - (a) reator anaeróbio de leito fluidificado $A$.

(b) reator anaeróbio de leito fluidificado $B$. 
O reator A, com volume de 16 litros e $1800 \mathrm{~mm}$ de altura e $93 \mathrm{~mm}$ de diâmetro, era constituído de 3 partes principais (entrada, corpo principal e seção de separação) conectadas por flanges e parafusos. A primeira parte, caracterizada pela entrada e distribuição do afluente, foi feita em aço inoxidável, e tinha uma placa perfurada responsável pela distribuição homogênea do fluido no reator. A segunda parte (reator propriamente dito), onde se localizou a biomassa fluidificada, era composta por um tubo de vidro de $3 \mathrm{~mm}$ de espessura, $1200 \mathrm{~mm}$ de altura e $93 \mathrm{~mm}$ de diâmetro. Essa parte era dotada de amostradores espaçados de $400 \mathrm{~mm}$ ao longo da altura. A terceira parte do reator caracterizou-se pela saída do efluente, do gás produzido, e pela saída da parcela do efluente a ser recirculada. Como a parte 1 , a parte 3 também foi construída em aço inoxidável

O reator $\mathrm{B}$, com volume de 2,2 litros, tinha os mesmos princípios construtivos do primeiro reator, apenas com a diferença de possuir dimensões menores (550 $\mathrm{mm}$ de altura e $50 \mathrm{~mm}$ de diâmetro interno) e apenas um amostrador na parte inferior do tubo, para coleta de biopartículas. Convém salientar que esse novo reator não foi projetado com as mesmas dimensões do antigo, principalmente pelo fato de ocorrer independência de algumas investigações, não havendo então a necessidade de se manter a mesma escala, minimizando inclusive os custos.

\subsubsection{LODO DE INÓCULO}

O inóculo utilizado em todos os experimentos foi proveniente de reator anaeróbio de manta de lodo e escoamento ascendente (UASB), tratando água residuária de abatedouro de aves (Dacar Industrial S.A.), sediada em Tietê, SP. Este lodo foi adotado porque era bem granulado e apresentou grande diversidade morfológica em ensaios realizados por outros pesquisadores. Vem sendo constantemente utilizado em processos de inoculação no LPB. Para avaliar a massa microbiana foi realizada a caracterização qualitativa através da microscopia óptica ${ }^{9}$. Os tipos morfológicos e a descrição dos microrganismos

\footnotetext{
${ }^{9}$ Material gentilmente cedido pela doutoranda Luana Maria Marelli, que utilizou o mesmo lodo para sua pesquisa (em andamento).
} 
encontrados nos grânulos, antes da inoculação, são apresentados na Figura 4.3.

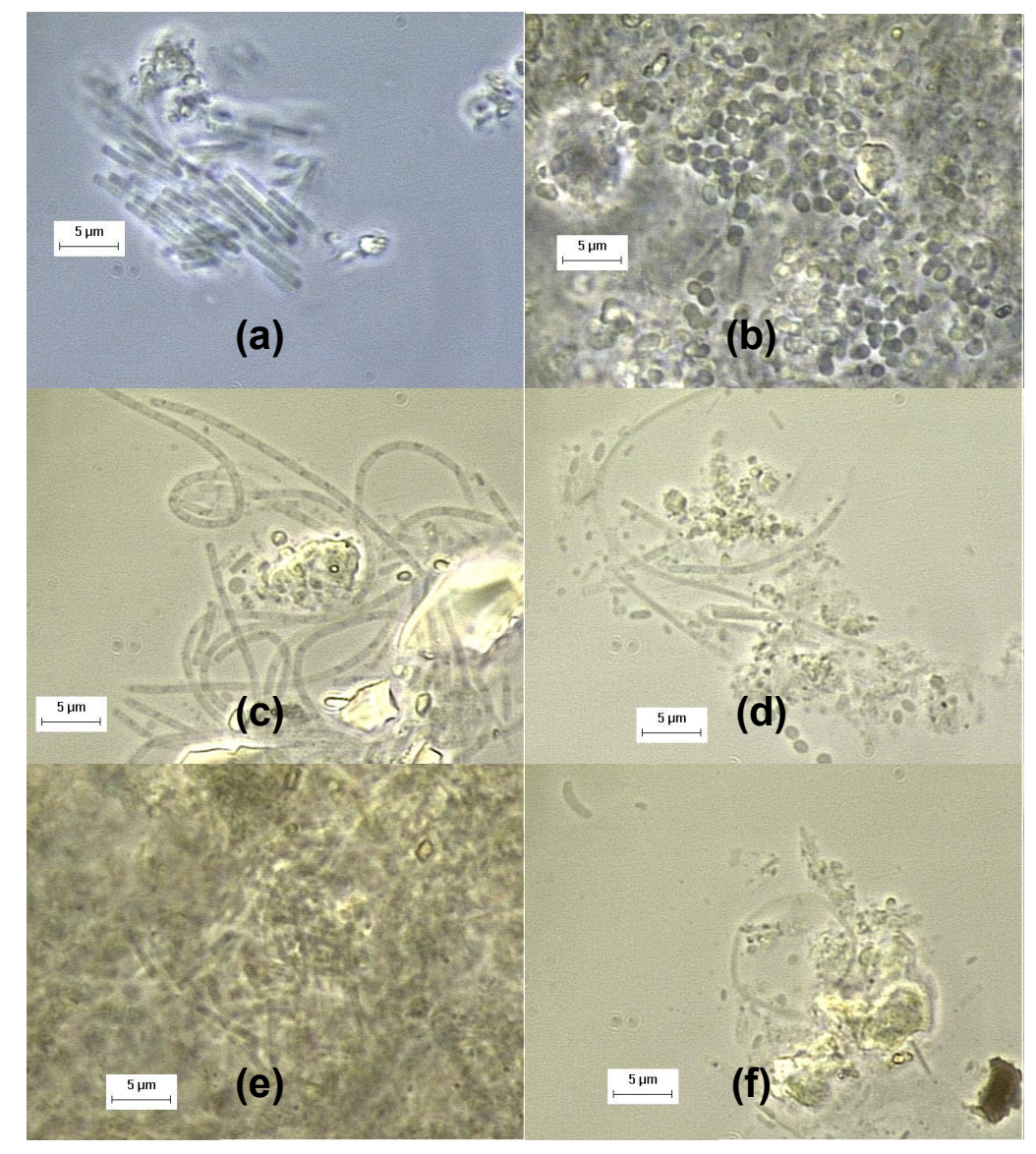

Figura 4.3 - Tipos morfológicos encontrados nos grânulos do lodo de inóculo. a) feixe de bacilos semelhantes a Methanosaeta sp.; b) aglomerado de cocos; c), d), e) e f) bacilos filamentosos e cocos.

A microscopia óptica do lodo, em microscópio Olympus $\mathrm{BH} 2$, foi realizada no próprio LPB. De maneira geral, as amostras coletadas foram colocadas em frascos contendo pérolas de vidro, onde se promovia a agitação para quebrar os grânulos do inóculo. As amostras líquidas foram então colocadas em lâminas com gel agar e observadas em microscópio.

O lodo anaeróbio utilizado para inocular o reator era constituído por grânulos bem consistentes de cor negra. Os principais tipos de microrganismos existentes no lodo e que aparecem em grande quantidade foram bacilos filamentosos, feixes de bacilos, bacilos isolados, cocos e vibrios semelhantes a 
bactérias redutoras de sulfato, além de microrganismos semelhantes ao gênero Methanosaeta,

\subsubsection{EFLUENTE SINTÉTICO}

O efluente sintético utilizado em todos os experimentos da pesquisa, cujas características de composição estão apresentadas na Tabela 4.1, era composto com glicose como fonte de carbono, além de sais e outros nutrientes. Este efluente foi preparado a partir de uma adaptação do efluente utilizado por Del Nery (1987).

Tabela 4.1 - Composição da água residuária sintética.

\begin{tabular}{cc}
\hline Composto & $\begin{array}{c}\text { Concentração } \\
\text { Original } \\
\text { (mg/L) }\end{array}$ \\
Glicose & 1000 \\
Uréia & 62,5 \\
Sulfato de níquel & 0,5 \\
Sulfato ferroso & 2,5 \\
Cloreto férrico & 0,25 \\
Cloreto de cálcio & 23,5 \\
Cloreto de cobalto & 0,04 \\
Óxido de selênio & 0,035 \\
Fosfato de potássio monobásico & 42,5 \\
Fosfato de potássio dibásico & 10,85 \\
Fosfato de sódio dibásico & 16,7 \\
Bicarbonato de sódio & 1000 \\
\hline
\end{tabular}

Fonte: adaptado de Del Nery (1987)

Os valores apresentados na Tabela 4.1 são baseados em uma concentração de glicose de 1000 mg/L, e demanda química de oxigênio (DQO) também da ordem de $1000 \mathrm{mg} / \mathrm{L}$. Para concentrações de DQO diferentes da 
estipulada na tabela, bastava apenas acrescentar os reagentes na proporção desejada.

O efluente utilizado por Del Nery (1987) teve como base de nutrientes a água utilizada para determinação de DBO, proposta pelo Standard Methods for the Examination of Water and Wastewater (APHA, 1995). A esses nutrientes, a pesquisadora acrescentou três fontes de carbono: glicose, acetato de amônia e metanol. A escolha da glicose como única fonte de carbono baseou-se em trabalhos anteriores. A glicose já havia sido utilizada conjuntamente com outras fontes de carbono em Damianovic (1997), Baraldi (2001), Oliveira (1998), dentre outros. Zaiat (1996) utilizou este mesmo efluente para dois experimentos: avaliação de transferência de massa externa e dos parâmetros cinéticos intrínsecos; e também para testes de desempenho em um reator anaeróbio horizontal de leito fixo (RAHLF).

Para facilitar a elaboração do efluente sintético foram preparadas duas soluções "estoque" em altas concentrações dos compostos reagentes, com exceção da glicose e do bicarbonato. Uma solução estoque foi composta pela uréia, os sulfatos e os cloretos, e a outra solução estoque exclusivamente pelos fosfatos. A divisão em duas soluções estoque foi orientação da responsável técnica do LPB (informação verbal) ${ }^{10}$. Para a estocagem em geladeira seria conveniente separar os fosfatos dos outros compostos, para não ocorrer reações que prejudicassem as características do efluente. Nos dias de preparação do efluente, essas soluções foram diluídas, e só então a glicose e o bicarbonato foram adicionados na proporção desejada.

Além do fato de esse efluente ter sido utilizado em outras pesquisas realizadas no LPB, a escolha também teve relação direta com uma das propostas deste trabalho, que era a de submeter o experimento a condições mais simplificadas. Além disso, outro fator preponderante para a escolha deste efluente está relacionado com a escala do experimento. Por exemplo, o reator A (com volume de 16 litros) utilizado na pesquisa era oito vezes maior (em volume) que o reator anaeróbio horizontal utilizado por Damianovic (1997) e Baraldi (2001). Em comparação a estes trabalhos, foi aplicado um tempo de detenção hidráulica reduzido (cerca de $8 \mathrm{hs}$ ), tendo como resultado uma

\footnotetext{
${ }^{10}$ Profa Elizabeth de Mattos Moraes.
} 
considerável vazão diária (os parâmetros operacionais do reator serão apresentados posteriormente).

Em virtude de serem necessários grandes volumes, era conveniente que a preparação do efluente fosse a mais simples possível, para economia não só de reagentes, mas também do tempo para prepará-lo. Por esse motivo optouse pelo efluente utilizado em Del Nery (1987). Esse efluente era composto por 12 reagentes. Para efeito de comparação, o meio Zinder, utilizado por muitos pesquisadores do LPB (dentre eles, Buzzini, 2000; Guaglianoni, 1998; Oliveira, 1998), é composto por quase 30 reagentes, incluindo soluções de traços de metais e de vitaminas.

\subsubsection{INOCULAÇÃO DOS REATORES}

Durante a pesquisa, o processo de imobilização de biomassa, que será descrito neste tópico, foi utilizado em todas as situações em que foi necessária a inoculação dos reatores.

Inicialmente o reator foi alimentado (em circuito fechado) por uma suspensão à base de efluente sintético (DQO $\approx 500 \mathrm{mg} / \mathrm{L})$ e do lodo de inóculo macerado em liquidificador. A solução foi elaborada numa proporção tal que resultasse numa concentração de sólidos totais voláteis de aproximadamente $200 \mathrm{mg} / \mathrm{L}$. Esse princípio de imobilização de biomassa mostrou-se eficiente tanto para sistemas em escala pequena como para reatores em maior escala, pois promove simultaneamente a adesão de biomassa nos suportes e a adaptação desses microrganismos ao substrato. A suspensão (lodo macerado + efluente sintético) foi bombeada para dentro do reator, sob uma baixa vazão de alimentação (cerca de 1 L/hora). Essa solução era renovada a cada 2 dias.

Após a fase de imobilização de biomassa, com duração de 28 dias, 0 reator ficou por cerca de 7 dias trabalhando como um filtro biológico, ou seja, como um reator de leito fixo, sendo alimentado apenas com o efluente, sem a introdução de lodo macerado. Essa fase foi programada para servir como uma transição entre as condições de circuito fechado e de leito fluidificado, para uma melhor adaptação da biomassa.

Após esse processo de inoculação, o reator ( $A$ ou $B$ ) foi então submetido às condições operacionais típicas de um RALF. 


\subsection{AVALIAÇÃO DOS MATERIAIS SUPORTE}

Partículas dos três materiais suportes selecionados, a alumina, o basalto e o carvão ativado, foram avaliadas previamente no que diz respeito às suas principais características, e depois foram colocadas como "recheio" em um reator de leito fluidificado (reator A) para estudo do comportamento fluidodinâmico do mesmo, e finalmente um ensaio foi elaborado para que seus potenciais de imobilização de biomassa fossem verificados. Após essa avaliação prévia, o material suporte que apresentou os melhores resultados foi escolhido para a continuidade do trabalho.

\subsubsection{CARACTERIZAÇÃO DAS PARTÍCULAS}

A caracterização das partículas consistiu em etapa importante na avaliação dos materiais suporte, pois através de uma série de análises foram determinadas suas principais propriedades físicas, além da estrutura em escala microscópica, e também um melhor conhecimento dos aspectos geométricos. As análises de caracterização foram as seguintes: porosimetria de mercúrio, adsorção e condensação de nitrogênio (BET), microscopia eletrônica de varredura (MEV) e análise de imagem. As análises de MEV da partícula sem biomassa imobilizada, bem como a porosimetria de mercúrio foram realizadas no Centro de Caracterização e Desenvolvimento de Materiais da UFSCar (CCDM) e a análise de BET foi realizada no laboratório de catálise do DEQ UFSCar.

A MEV é utilizada com freqüência nas pesquisas realizadas no LPB e a técnica de preparação das amostras (com biomassa imobilizada) é amplamente conhecida, e será apresentada posteriormente quando forem tratadas as interações entre partícula e biomassa. Com relação a porosimetria de mercúrio e ao BET, pelo fato de serem análises extremamente complexas, e dessa etapa ser considerada uma ferramenta para o andamento do trabalho, e não seu objeto principal, optou-se por apresentar uma descrição simplificada dos métodos, contendo apenas os princípios, aplicações e equipamentos utilizados em cada um. 


\subsubsection{POROSIMETRIA DE MERCÚRIO}

A porosimetria de mercúrio determina a distribuição de tamanho e volume de poros em materiais sólidos e particulados através da intrusão e extrusão de mercúrio sob pressão. Possibilita ainda a determinação da estrutura dos poros interconectantes e intraglomerados e a área superficial de materiais particulados. Esta técnica indica somente os poros abertos à superfície externa da amostra. Poros grandes conectados à superfície por canais de diâmetro menor terão seus respectivos volumes indicados por pressões que correspondem aos dos canais de comunicação.

O equipamento (poresizer 9320 da Micromeritics) é hidráulico e está acoplado a um computador para cálculo e obtenção dos dados. Mede poros na faixa de 360 a $6 \mu \mathrm{m}$ a baixas pressões (0 a 30 psia) e de 6 a 0,006 $\mu \mathrm{m}$ a altas pressões (30 a 30000 psia). Através da análise de porosimetria de mercúrio foram determinados os seguintes parâmetros: densidade $\left(\mathrm{g} / \mathrm{cm}^{3}\right)$, densidade aparente $\left(\mathrm{g} / \mathrm{cm}^{3}\right)$, área total de poros $\left(\mathrm{m}^{2} / \mathrm{g}\right)$, diâmetro médio de poro $(\mathrm{mm})$ e porosidade (\%).

\subsubsection{ANÁLISE DE ADSORÇÃO FÍSICA (BET)}

A análise de BET determina a área específica e a porosidade de materiais particulados. A técnica basicamente consiste na medida das alterações sofridas por mistura de $10 \%$ de nitrogênio em hélio quando uma amostra é submetida a variação de pressão, na temperatura do nitrogênio líquido. Pode-se relacionar a área específica do material a partir da adsorção física de moléculas de nitrogênio na superfície da amostra. Equipamento: ASAP 2000 da Micromeritics. Pelo BET foi determinada a área específica das partículas $\left(\mathrm{m}^{2} / \mathrm{g}\right)$.

\subsubsection{ANÁLISE DE IMAGEM}

A análise de imagem foi realizada no DEQ - UFSCar através de um sistema integrado mostrado na Figura 4.4. Este sistema era formado por um microscópio óptico (Olympus BX60), uma câmera registradora de imagens 
conduzindo informações a um software (Image Pro Plus 3.0) em um microcomputador. Ele permite uma série de análises através de imagens, destacando-se: a contagem do número de partículas distribuídas na superfície do disco, a determinação do diâmetro médio, a área e o perímetro das partículas. Para este trabalho, além do registro de imagem e da contagem do número de partículas, foi determinado também, para cada uma, o diâmetro máximo, mínimo e médio.

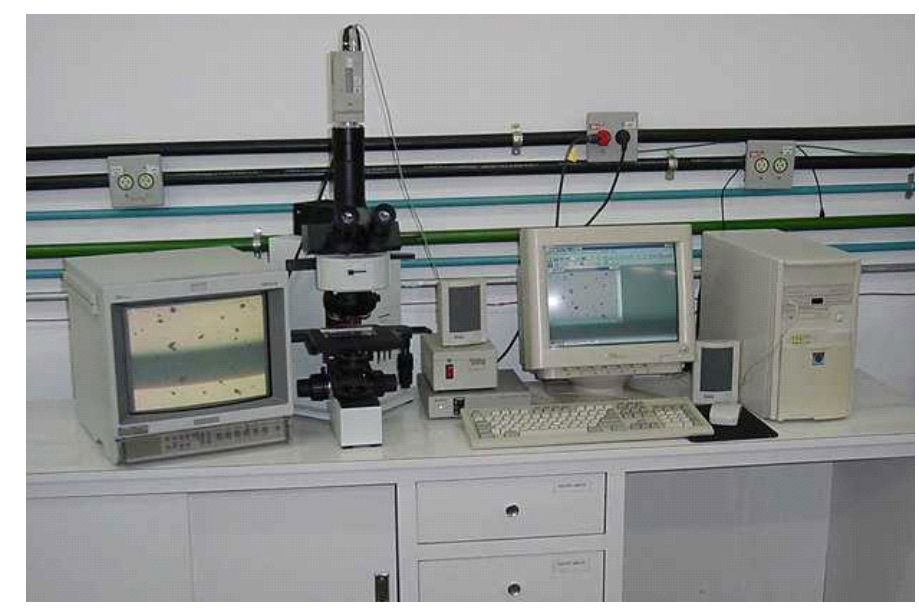

Figura 4.4 - Sistema integrado para análise de imagens das partículas inertes.

\subsubsection{FLUIDODINÂMICA NO REATOR A}

O sistema experimental do ensaio foi montado no Laboratório de Sistemas Particulados do DEQ - UFSCar e pode ser visualizado na Figura 4.5. Para os ensaios fluidodinâmicos do reator $A$, o sistema foi considerado bifásico (líquido / sólido) e o fluido utilizado foi a água de torneira. Dessa maneira, para cada material suporte empregado foram obtidos importantes parâmetros de funcionamento, tais como a velocidade de mínima fluidificação, as pressões de trabalho, a expansão do leito, bem como a sua porosidade.

$O$ basalto e o carvão foram peneirados na faixa de diâmetros conveniente. Atingido este estágio de andamento, as partículas de alumina e de basalto estavam prontas para serem colocadas dentro do reator, sendo cada uma no momento de realização de seu respectivo ensaio. A técnica de colocação das partículas dentro do reator foi o lançamento manual por cima, 
através da retirada do tampão superior, e com o auxílio de um funil. O procedimento com o carvão ativado nessa etapa, entretanto, foi um pouco diferente do empregado para os outros materiais.

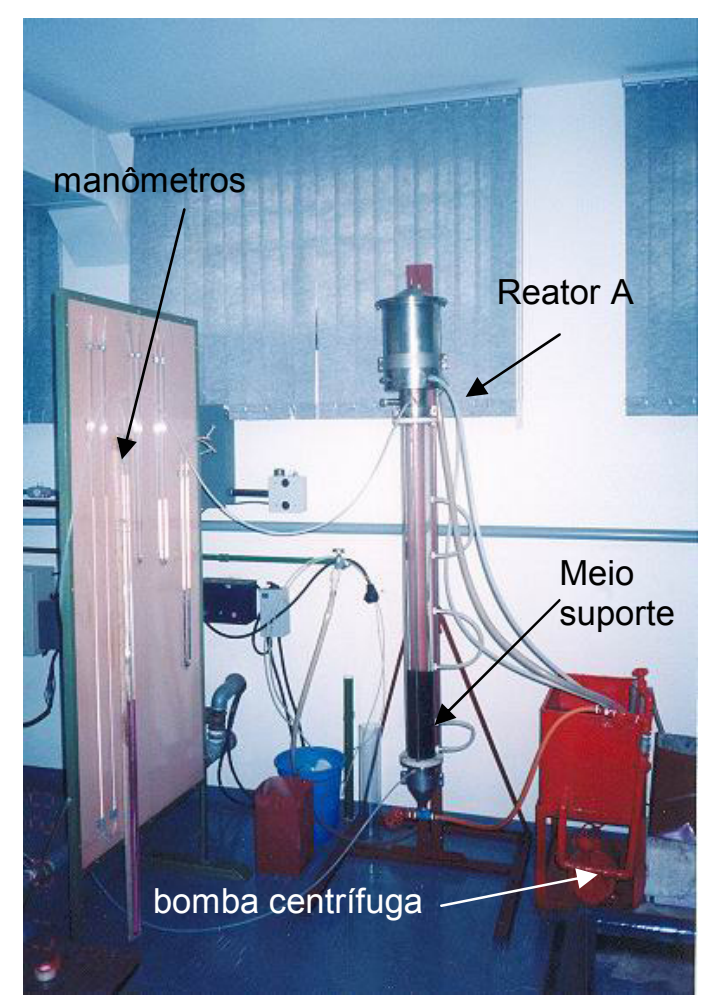

Figura 4.5 - Sistema experimental utilizado para os ensaios fluidodinâmicos no reator $A$.

Após o peneiramento, as partículas de carvão ficaram por 24 hs em um recipiente com água. Devido à sua baixa densidade, uma grande parcela de partículas (por volta de $30 \%$ do total) flutuava e ficava na superfície do recipiente. Essa parcela era retirada e descartada e apenas a parcela que afundava era colocada dentro do reator. Com as partículas já dentro do reator, o próximo passo foi garantir que a melhor condição possível de fluidificação fosse atingida.

A necessidade de ajustes foi verificada através de observações visuais do comportamento das partículas na parte superior da fluidificação. As partículas mais instáveis e leves, que ficavam nessa região, certamente iriam prejudicar a qualidade dos ensaios fluidodinâmicos, como as leituras de expansão do leito, por exemplo. O procedimento adotado foi o de sempre colocar uma quantidade de carvão maior que a necessária e expulsar essas 
partículas instáveis do leito através do aumento da vazão, até que se obtivesse uma região de "topo" com comportamento mais homogêneo possível, característica importante para uma fluidificação de qualidade.

Para uma boa reprodutibilidade, todos os ensaios foram realizados, no mínimo, em triplicata. Inicialmente foram obtidas as curvas características para cada suporte: diferença de pressão no leito em função da velocidade ascensional do líquido. Para o bombeamento da água foi utilizada uma bomba centrífuga da marca MARK, modelo XD2, com motor de $1 / 2 \mathrm{CV}$. Caso houvesse necessidade da aplicação de grandes vazões, em virtude da utilização de materiais suporte mais pesados, uma outra bomba (marca KOLBACH com motor de $1 / 3 \mathrm{CV}$ ) foi instalada em paralelo com a primeira. Para a medida da diferença de pressão, entre a entrada e a saída do reator, um manômetro de tetracloreto foi instalado, com mangueiras conectadas a esses dois pontos, como mostrou a Figura 4.5.

As vazões aplicadas foram determinadas pelo método gravimétrico (Figura 4.6), ou seja, pela razão entre massa de efluente e tempo necessário para se obter essa massa. Para fornecer uma medida de vazão mais precisa, optou-se por utilizar a massa, ao invés do volume, uma vez que se dispunha de uma balança com precisão de $1 \mathrm{~g}$. E finalmente as velocidades superficiais ascensionais foram obtidas dividindo-se a vazão pela área transversal da coluna do reator.

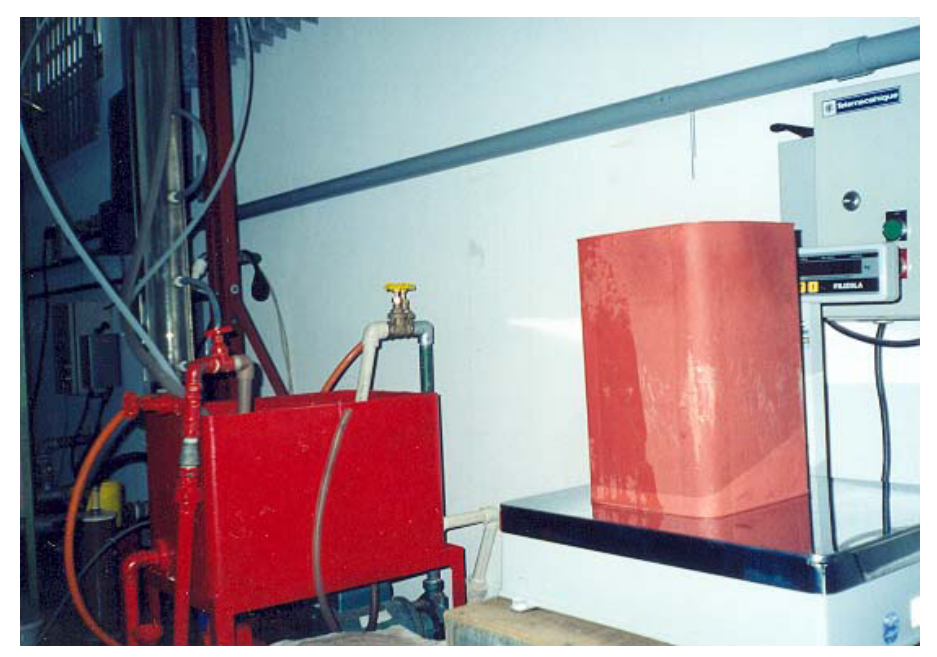

Figura 4.6 - Método gravimétrico para determinação das vazões aplicadas ao reator. 
A diferença de pressão devido à fluidificação do leito $\left(\Delta \mathrm{P}_{\text {FLUID }}\right)$ foi obtida subtraindo-se a diferença de pressão do leito vazio $\left(\Delta \mathrm{P}_{\text {VAzIO }}\right)$, ou seja, do reator sem partículas, da diferença de pressão total (reator com a partícula). Portanto um teste inicial com o reator vazio (sem partículas) foi efetuado para a obtenção de $\Delta \mathrm{P}_{\text {VAZIO }}$. Aos pontos obtidos para o reator vazio foi ajustada uma equação de segundo grau, obtendo-se uma relação entre diferença de pressão e velocidade. Assim, foi possível determinar a diferença de pressão para qualquer velocidade.

Posteriormente, cada tipo de partícula foi introduzido ao reator para a obtenção da diferença de pressão total. Dessa maneira:

$$
\Delta \mathrm{P}_{\mathrm{FLUID}}=\Delta \mathrm{P}_{\mathrm{TOTAL}}-\Delta \mathrm{P}_{\mathrm{VAZIO}}
$$

Segundo Briens et al. (1997a), a curva característica para cada material apresenta então duas regiões lineares claramente distintas, cuja intersecção fornece a velocidade mínima de fluidificação.

Posteriormente aos ensaios para obtenção das curvas características, foram feitos os ensaios de expansão do leito, que consistiam em medir a expansão do leito (em centímetros) correspondente a valores crescentes de vazão. A expansão foi medida diretamente no leito, através de régua graduada.

O ensaio prosseguiu até a determinação da maior altura estipulada. Essa altura pode ser adotada a critério do pesquisador (por exemplo, até uma expansão de $60 \%$ ), ou limitada pelo equipamento (altura do reator ou vazão máxima da bomba). Dessa maneira, para cada altura do leito, o volume total do leito será definido como:

$$
\mathrm{V}_{\text {TOTAL }}^{\mathrm{i}}=\mathrm{V}_{\mathrm{s}}+\mathrm{V}_{\mathrm{LIQ}}^{\mathrm{i}}
$$

Na qual:

$\mathrm{i}$ : número inteiro $(\mathrm{i}=0,1,2,3, \ldots, \mathrm{n})$ que representa o número de pontos experimentais obtidos;

$V_{S}$ : Volume de sólidos;

$\mathrm{V}_{\mathrm{LIQ}}^{\mathrm{i}}$ : Volume de líquido correspondente à altura do leito $h_{\mathrm{i}}$ 
Após os ensaios de expansão, a determinação da porosidade do leito obedeceu a seguinte seqüência de cálculos:

- Cálculo do volume total:

Para cada velocidade superficial (partindo do repouso) e sua correspondente altura de leito era calculado o volume total (partículas + líquido) da seguinte maneira:

$$
\mathrm{V}_{\mathrm{TOTAL}}^{\mathrm{i}}=\mathrm{A}_{\mathrm{TR}} \cdot \mathrm{h}_{\mathrm{i}}
$$

Na qual:

$\mathrm{V}_{\text {TOTAL }}^{\mathrm{i}}$ : Volume total (líquido + sólido) correspondente a uma determinada altura do leito $\left(\mathrm{h}_{\mathrm{i}}\right)$;

$A_{T R}$ : Área transversal da coluna do reator;

$h_{\mathrm{i}}$ : Altura do leito para uma velocidade superficial $U_{i}$.

- Volume de sólidos

Como não se alterou a quantidade de sólidos mantida no reator durante os ensaios, o volume de sólidos permaneceu constante para todas as velocidades superficiais aplicadas. Assim, sua determinação foi obtida através da seguinte expressão:

$$
\mathrm{V}_{\mathrm{S}}=\mathrm{V}_{\mathrm{TOTAL}}^{0}-\mathrm{V}_{\mathrm{LIQ}}^{0}
$$

Na qual:

$\mathrm{V}_{\mathrm{S}}$ : Volume de sólidos;

$\mathrm{V}_{\mathrm{TOTAL}}^{0}$ : Volume total do leito na situação de repouso;

$\mathrm{V}_{\mathrm{LIQ}}^{0}$ : Volume de líquido correspondente a altura do leito em repouso (estática), foi medido diretamente através de coleta no reator e posterior pesagem. 
- Cálculo da porosidade:

Após a seqüência de cálculos, a porosidade $(\varepsilon)$, para cada altura do leito, foi finalmente calculada:

$$
\varepsilon_{\mathrm{i}}=\frac{\left(\mathrm{V}_{\mathrm{TOTAL}}^{\mathrm{i}}-\mathrm{V}_{\mathrm{S}}\right)}{\mathrm{V}_{\text {TOTAL }}^{\mathrm{i}}}
$$

\subsubsection{POTENCIAL DE IMOBILIZAÇÃO DE BIOMASSA}

Este ensaio (Figura 4.7) foi realizado nas dependências do LPB. Para a concretização dessa etapa, inicialmente foi importante realizar um estudo da literatura, analisando-se métodos de imobilização de biomassa que poderiam servir, conjuntamente com a fluidodinâmica e a caracterização das partículas inertes, como um bom mecanismo de avaliação dos materiais suporte.

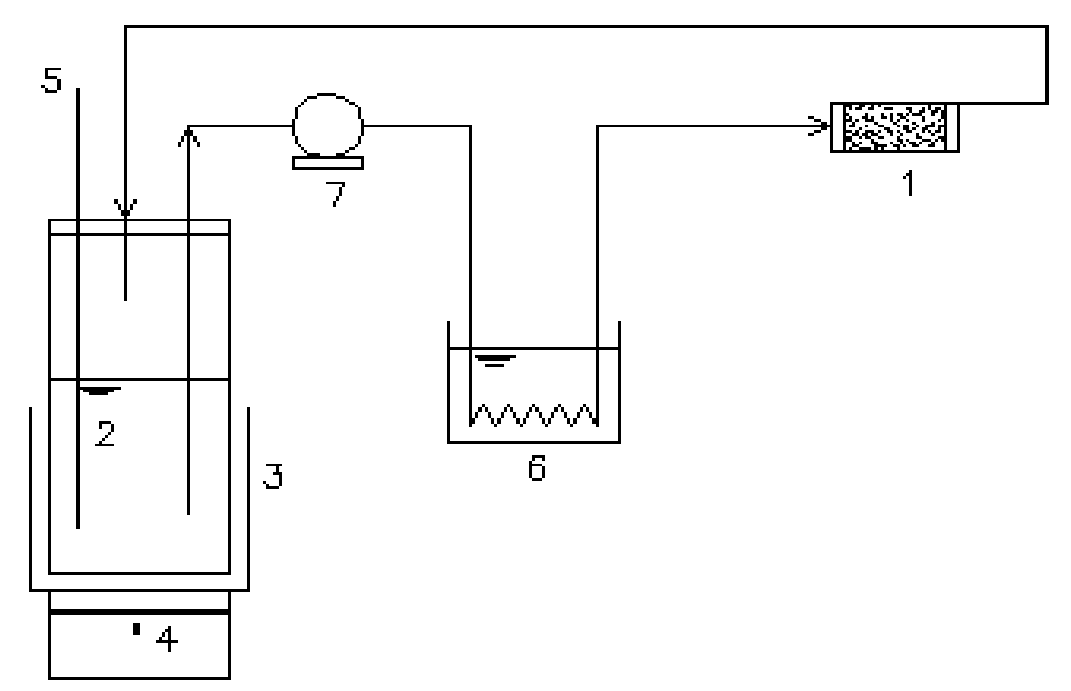

Figura 4.7 - Aparato experimental do ensaio de imobilização de biomassa para avaliação dos materiais suporte. (1) Reator "elemento de volume" (2) Reservatório para efluente (3) Banho de Gelo, (4) Agitador Magnético, (5) Amostrador, (6) Trocador de Calor, (7) Bomba peristáltica. 
Por já existir no próprio LPB um histórico de pesquisas bem sucedidas enfocando verificações semelhantes, logo se concluiu que uma adaptação desses métodos para a situação particular da pesquisa seria a solução mais apropriada. Dessa maneira, a escolha também levou em consideração uma menor dificuldade na aquisição dos equipamentos, e também a possibilidade de discussão e comparação de resultados com colegas de trabalho.

O sistema experimental desenvolvido para o ensaio de imobilização é uma adaptação do sistema encontrado nos trabalhos de Zaiat (1996), Silva et al. (2002), Ribeiro (2001) e Tommaso (1999). Esse sistema constituía-se basicamente de quatro reatores "elementos de volume" operando em paralelo, alimentados em circuito fechado por uma suspensão à base de efluente sintético e lodo de reator anaeróbio (UASB) proveniente de tratamento de água residuária de um abatedouro de aves, sendo que a idéia principal era a de se acompanhar a evolução da adesão de biomassa nos suportes colocados dentro dos reatores.

O ensaio de imobilização de biomassa foi realizado da seguinte maneira: os quatro reatores (Figura 4.8) foram preenchidos com massas iguais (ou extremamente próximas) do mesmo material suporte, ou seja, alumina, ou basalto, ou carvão ativado. A suspensão, contendo o efluente sintético (DQO $500 \mathrm{mg} / \mathrm{L}$ ) e lodo macerado em liquidificador numa proporção tal que resultasse numa concentração de sólidos totais voláteis de aproximadamente $100 \mathrm{mg} / \mathrm{L}$, era colocada no reservatório de efluente, e mantida agitada ininterruptamente.

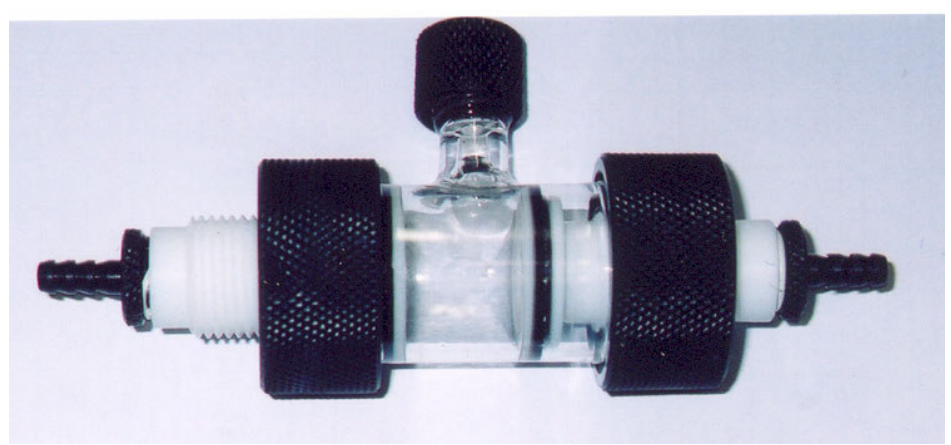

Figura 4.8 - Reator "elemento de volume" utilizado nos ensaios de imobilização de biomassa para avaliação dos três materiais suporte. 
Essa solução era então bombeada para os quatro reatores, através de uma bomba peristáltica da IsmatecK, com quatro canais, de maneira que todos fossem submetidos à mesma velocidade de escoamento, aproximadamente $0,03 \mathrm{~cm} / \mathrm{s}$.

Os reatores foram mantidos em uma câmara com temperatura controlada em $30^{\circ} \mathrm{C}$, enquanto que a solução, com auxílio do banho de gelo, foi mantida numa temperatura de aproximadamente $4^{\circ} \mathrm{C}$, criando assim condições ótimas e um ambiente propício para garantir que reações e processos de formação de biofilme fossem preferencialmente obtidos dentro dos reatores, e minimizados fora deles.

Diariamente uma nova suspensão (efluente mais microrganismos) era preparada, e colocada no sistema. O monitoramento do sistema foi feito através de análises de pH e DQO, e a evolução da adesão de biomassa foi acompanhada indiretamente através de ensaio de sólidos totais voláteis (STV), retirando-se, a cada 7 dias, um reator de cada conjunto, totalizando 28 dias de ensaio para cada material suporte.

Foi possível assim, verificar a massa de microrganismos presente em cada reator e comparar o potencial de imobilização de biomassa dos diferentes materiais suportes. Com a finalidade de facilitar essa comparação, os resultados foram apresentados em massa de microrganismos (mgSTV) por massa de suporte (gSUP) e também em massa de microrganismos por volume do reator (mgSTV / Vreator).

\subsubsection{ESCOLHA}

Os materiais foram julgados de acordo com as informações obtidas nos ensaios de avaliação, e aquele que obteve os melhores resultados foi escolhido para a continuidade do trabalho.

\subsection{ESTUDO DAS INTERAÇÕES}

Ao longo de toda a pesquisa foram realizadas diversas análises que de alguma forma forneciam informações sobre as interações dos componentes do sistema. Por adquirirem esse caráter diferenciado, as interações foram 
agrupadas e serão descritas neste item. Todas as interações já foram realizadas com o material suporte escolhido na etapa de avaliação prévia.

\subsubsection{INTERAÇÕES ENTRE AS PARTÍCULAS INERTES E O FLUIDO}

As interações entre partículas inertes e o fluido foram analisadas através de ensaios fluidodinâmicos e de isotermas de adsorção. Embora esta informação já tenha sido dada, é importante ressaltar que a fluidodinâmica foi realizada nos dois reatores, porém, com objetivos bem distintos. No reator $A$, a fluidodinâmica foi uma investigação rápida, que tinha apenas o objetivo específico de complementar a análise dos materiais suporte. Já no reator $B$, que foi construído especialmente para essa finalidade, a fluidodinâmica foi realizada de maneira mais aprofundada e abrangente, justamente para cumprir um dos principais enfoques da pesquisa, ou seja, questões mais fundamentais relacionadas com o escoamento. No reator $B$, os ensaios foram realizados com o material suporte que obteve os melhores resultados.

\subsubsection{FLUIDODINÂMICA DO REATOR B COM PARTÍCULAS INERTES}

A metodologia aplicada para a realização dos ensaios fluidodinâmicos no reator $B$ foi muito semelhante à utilizada no reator $A$. A fim de se obter maior reprodutibilidade, todos os ensaios fluidodinâmicos foram realizados, no mínimo, em duplicata, e as vazões foram obtidas através de um medidor de vazões tipo orifício, fabricado no DEQ - UFSCar, previamente calibrado e conectado a um manômetro de mercúrio.

O princípio básico do medidor de vazão tipo orifício (Figura 4.9) é proporcionar uma perda de carga localizada, através do estrangulamento da secção. Essa perda de carga localizada, que é correlacionada com a vazão no conduto, foi medida através de um manômetro de mercúrio (em $\mathrm{mmHg}$ ). Portanto, na calibração, primeiramente as vazões foram medidas através do método gravimétrico, fazendo-se também as leituras de perda de carga. De posse dos valores de vazão e das perdas de carga associadas, foi possível fazer a curva de calibração do medidor de vazão. Posteriormente, para 
determinar as vazões no conduto bastava apenas fazer a leitura da perda de carga.

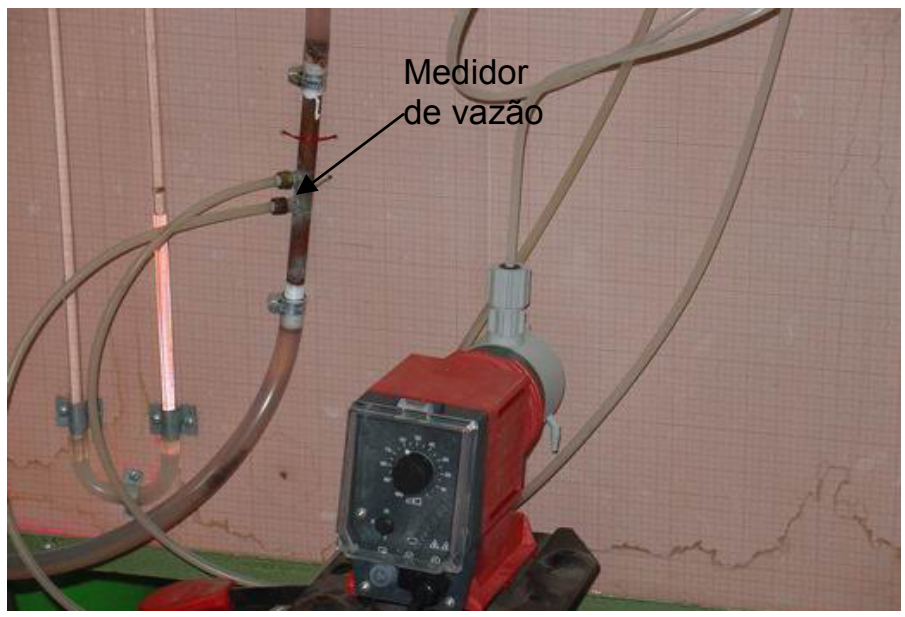

Figura 4.9 - Medidor de vazão tipo orifício.

O sistema experimental utilizado é mostrado na Figura 4.10.

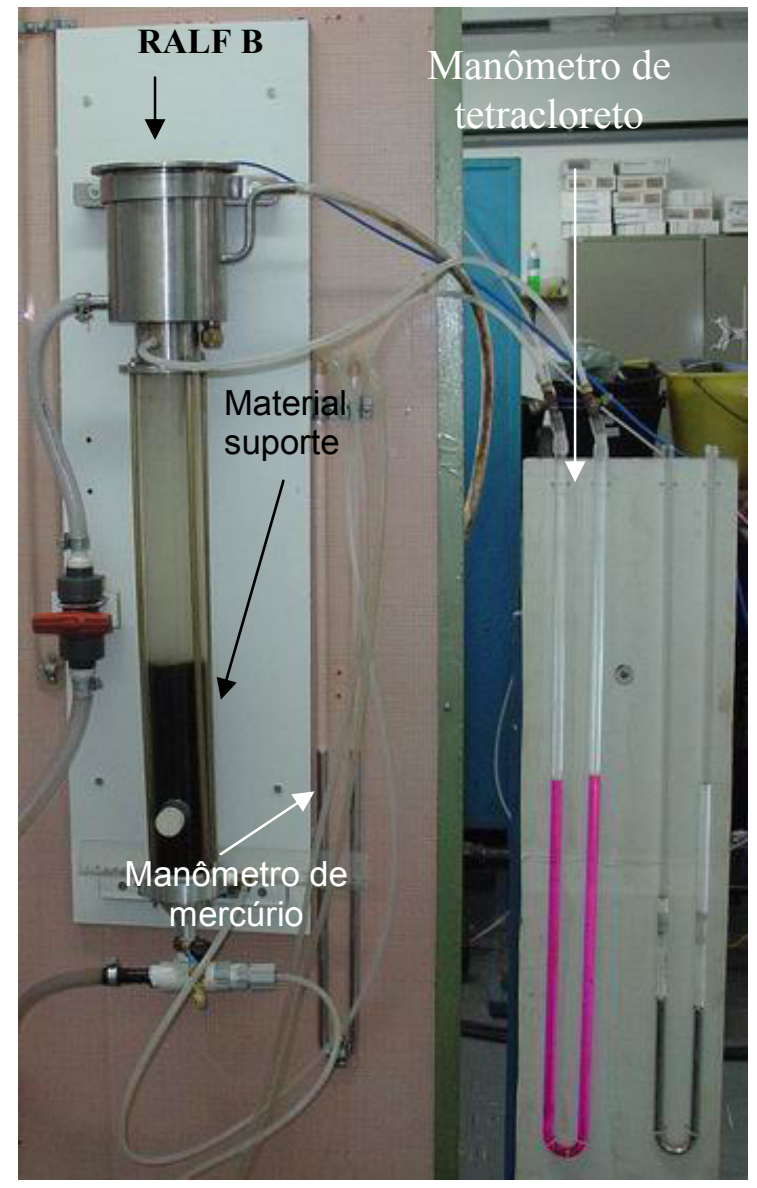

Figura 4.10 - Sistema experimental utilizado para os ensaios fluidodinâmicos no reator $B$. 


\subsubsection{ISOTERMAS DE ADSORÇÃO COM PARTÍCULAS INERTES}

O ensaio para determinação das isotermas de adsorção foi realizado no Laboratório de Sistemas Particulados do DEQ - UFSCar. As isotermas podem ser representadas por equações simples que relacionam diretamente o volume adsorvido em função da pressão e/ou concentração do adsorvato e as mais utilizadas no estudo da adsorção são as seguintes: Langmuir, Freundlich, Henry, Temkin, Giles e BET (RUTHVEN, 1984).

Apesar de existirem diferentes metodologias e equacionamentos, todas obedecem a um procedimento experimental básico: colocar em contato a solução contendo o componente a ser adsorvido com o material adsorvente, até atingir o equilíbrio. Algumas metodologias recomendam que uma solução com concentração única seja colocada em contato com diferentes massas de material adsorvente. Outras, sugerem exatamente o contrário, ou seja, que soluções com diferentes concentrações sejam colocadas em contato com uma mesma massa de material adsorvente. Porém, o princípio para os dois casos é o mesmo.

Neste trabalho, a adsorção do PCP no material suporte escolhido foi avaliada segundo os equacionamentos descritos pelas isotermas de Langmuir e de Freundlich, que são geralmente os métodos mais utilizados. $O$ procedimento experimental, entretanto, foi comum às duas isotermas.

Inicialmente foi realizado um processo de condicionamento do material suporte, através de 3 lavagens em água destilada e posterior colocação em estufa $\left(\mathrm{a} 105^{\circ} \mathrm{C}\right)$ por um período de $24 \mathrm{hs}$.

A cada um de seis erlenmeyers, limpo e seco, foi acrescentado um grama do material suporte escolhido e $100 \mathrm{~mL}$ de solução de PCP em diferentes concentrações. As seis concentrações pretendidas de PCP ficaram em uma faixa entre 10 e $21 \mathrm{mg} / \mathrm{L}$, porém, não houve extremo rigor na preparação das soluções, pois antes do ensaio propriamente dito, essas concentrações foram conferidas em análises de concentração de PCP. A um erlenmeyer de controle, sem o material suporte, foi adicionado $100 \mathrm{~mL}$ de solução em uma das concentrações que foram empregadas. Todos os frascos foram tampados com rolhas de borracha e deixados em agitação em um "shaker" (marca Tecnal, modelo TE 420) por 35 minutos, sob temperatura 
controlada de $30^{\circ} \mathrm{C}$. Após a agitação, os frascos foram deixados dentro do agitador por um período de 24 horas para que o equilíbrio fosse atingido.

Em seguida as amostras foram filtradas, inclusive do frasco controle, e descartados os primeiros $10 \mathrm{~mL}$ de cada uma, como precaução contra a adsorção do PCP no papel de filtro. Alíquotas de cada amostra foram retiradas para a determinação da concentração final em cada frasco, através de cromatografia gasosa, método que será descrito posteriormente.

No procedimento deste trabalho, as isotermas foram feitas para duas soluções distintas. Uma solução com água destilada e PCP e outra com o mesmo efluente sintético utilizado nos reatores (com DQO de aproximadamente $1000 \mathrm{mg} / \mathrm{L}$ ), acrescido de PCP, nas mesmas concentrações que foram empregadas no primeiro ensaio. Dessa maneira, foi possível avaliar a influência do efluente na adsorção do PCP e a competição pelos sítios ativos das partículas. Com exceção dessa única diferença, o procedimento experimental descrito foi o mesmo para as duas isotermas.

\section{Isotermas de Langmuir}

Tanto o procedimento experimental como a adsorção segundo a isoterma de Langmuir foram realizados a partir de uma adaptação de metodologia obtida no Instituto de Química de São Carlos (IQSC - USP) ${ }^{11}$. A metodologia original previa a determinação da isoterma de Langmuir para a adsorção do ácido acético em carvão ativado.

Esta forma de isoterma é a mais freqüentemente utilizada e pode ser expressa como:

$$
W=\frac{K^{\prime} b C}{1+K^{\prime} C} \quad \text { ou } \quad \frac{1}{W}=\frac{1}{K^{\prime} b} \cdot \frac{1}{C}+\frac{1}{b}
$$

Em que $W$ é a quantidade adsorvida por massa de adsorvente, $\mathrm{C}$ a concentração no fluido (no equilíbrio), b e K' são constantes. K'é a constante de equilíbrio e está relacionada com a energia livre de adsorção, que corresponde

\footnotetext{
${ }^{11}$ Material gentilmente cedido pelo Prof. Artur de Jesus Moteo, do IQSC.
} 
à afinidade entre a superfície do adsorvente e o soluto. A constante "b" representa a cobertura de adsorvato em uma monocamada, ou seja, a máxima adsorção possível. Caso o sistema obedeça a isoterma de Langmuir, o gráfico de 1/W em função de 1/C deve resultar em uma linha reta, de acordo com a equação 4.6. Os parâmetros K' e b são determinados a partir dos coeficientes angular e linear da reta.

\section{Isotermas de Freundlich}

A isoterma de Freundlich corresponde a uma distribuição exponencial de adsorção. Este modelo pode ser expresso por:

$$
W=b \cdot C^{m} \quad \text { ou } \quad \log W=m \cdot \log C+\log b
$$

Na qual $m<1$. Os valores de "W" e " $C$ " têm o mesmo significado daqueles já definidos para a isoterma de Langmuir, e "b" e "m" são constantes que dependem de diversos fatores experimentais e se relacionam com a distribuição dos sítios ativos e a capacidade de adsorção do adsorvente (CIOLA, 1981).

A equação de Freundlich foi originalmente introduzida como uma correlação empírica de dados experimentais, sendo derivada matematicamente só apenas nos anos 70 , admitindo-se uma distribuição logarítimica de sítios ativos, que constitui um tratamento válido quando não existe interação apreciável entre as moléculas de adsorvato (RUPP, 1996).

\subsubsection{INTERAÇÃO ENTRE AS BIOPARTÍCULAS E O FLUIDO}

As interações entre as biopartículas e o fluido foram analisadas através de ensaios de fluidodinâmica (no reator $B$ ). Com exceção de que houve inicialmente um processo de inoculação para imobilização de biomassa (descrito no item 4.2.5 deste capítulo) e do fluido utilizado ter sido o efluente sintético, a metodologia dos ensaios de fluidodinâmica do reator B com biopartículas foi exatamente igual aos ensaios de fluidodinâmica com partículas inertes. 
Após a inoculação, o reator $B$ foi colocado em condições típicas de um RALF. O efluente sintético foi transportado para o reator através de bomba dosadora solenóide marca Prominent, modelo Conb 1201 e parte do efluente foi recirculada através de uma bomba centrífuga da marca MARK, modelo XD2, com motor de $1 / 2 \mathrm{CV}$, para garantir as condições de fluidificação do leito. A fluidificação permitiu o arraste do excesso de biomassa, restando apenas a parcela que interessava, ou seja, aquela que estava aderida firmemente ao meio suporte escolhido.

Após esse processo o reator $B$ foi considerado apto para os ensaios fluidodinâmicos com biopartículas, e repetiu-se a metodologia descrita no item 4.4.1.2. Para a estimativa prévia da quantidade de biomassa aderida ao material suporte, utilizou-se o "método de dissolução do biofilme com soda cáustica", descrito por Chen e Chen (2000).

\subsubsection{INTERAÇÃO ENTRE PARTÍCULA INERTE E FLUIDO}

Para analisar a interação entre uma única partícula e o fluido foi elaborado e realizado neste trabalho um procedimento experimental para a determinação da velocidade terminal da partícula $\left(U_{t}\right)$ para partículas inertes do melhor material escolhido na etapa de avaliação.

Em virtude da grande irregularidade geométrica de algumas partículas analisadas (carvão e basalto), uma grande amostragem de partículas foi programada para ser utilizada (50 partículas), para que se garantisse uma média confiável.

$\mathrm{Na}$ véspera do ensaio de coluna, as 50 partículas inertes foram retiradas do reator $B$ (que estava sendo utilizado para os ensaios fluidodinâmicos) e deixadas submersas em água por 24 horas. Basicamente, o ensaio consistia em colocar as partículas individualmente, a partir do repouso, em uma coluna contendo água (Figura 4.11), com altura de $1000 \mathrm{~mm}$ e diâmetro de $50 \mathrm{~mm}$, graduada de $200 \mathrm{em} 200 \mathrm{~mm}$, conforme os pontos (0,1,2,3,4 e 5) mostrados na Figura 4.11. Determinou-se então, através de observação visual e um cronômetro, o tempo necessário para cada partícula percorrer os $400 \mathrm{~mm}$ correspondentes à distância entre os pontos 2 e 4, e por fim obteve-se a 
velocidade terminal através da razão entre o espaço percorrido (400 mm) e o tempo gasto. O ensaio com partículas inertes foi realizado em uma única etapa.

É importante salientar que para uma medida acurada da velocidade terminal da partícula é necessário garantir que esta partícula esteja com velocidade constante, ou seja, com aceleração nula. Esta obrigatoriedade, inclusive, é o motivo para esta velocidade ser denominada "terminal". Testes iniciais foram realizados com o material suporte escolhido para a verificação da velocidade constante na coluna (ver capítulo de resultados).

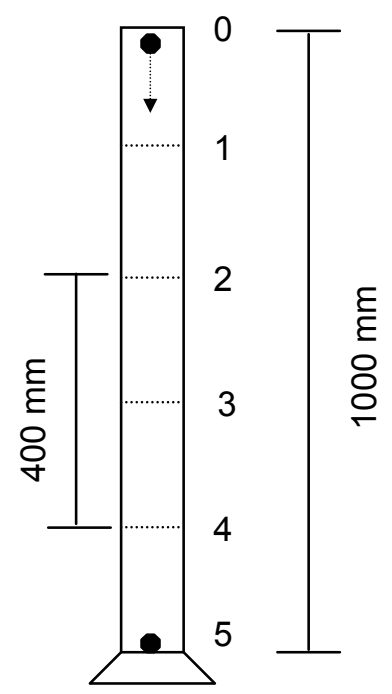

Figura 4.11 - Desenho esquemático do ensaio em coluna para determinação da velocidade terminal da partícula.

\section{Equação de Richardson e Zaki:}

$\mathrm{Na}$ seqüência dos ensaios para determinação de $U_{t}$ foi obtido o parâmetro $n$ da equação de Richardson e Zaki, que descreve o efeito da presença da fase particulada na fluidodinâmica de suspensões:

$$
U_{\infty}=\varepsilon^{n}
$$


Segundo Almeida (1995), para uma relação entre diâmetro de partícula $\left(d_{p}\right)$ e diâmetro da coluna $\left(D_{c}\right)$ próxima a 0,05 , o valor de $U_{t}$ se torna uma adequada aproximação da velocidade terminal da partícula isolada $\left(U_{\infty}\right)$.

Dessa maneira, adotando-se para $U_{\infty}$ os valores obtidos para $U_{t}$ no ensaio em coluna, e substituindo na equação 3.6 os valores de velocidade ascensional $(U)$ e porosidade $(\varepsilon)$ que foram obtidos nos ensaios anteriores, chega-se finalmente ao valor do parâmetro $n$ da equação.

\subsubsection{INTERAÇÃO ENTRE BIOPARTÍCULA E FLUIDO}

Para efeito de comparação, foi elaborado e realizado neste trabalho um ensaio experimental para a determinação da velocidade terminal da partícula $\left(\cup_{t}\right)$ também para biopartículas.

Os ensaios de $U_{t}$ das biopartículas foram realizados em 4 etapas, de 20 em 20 dias, e após todas as outras etapas experimentais. As biopartículas foram retiradas do reator $B$. Os parâmetros operacionais do reator no momento da coleta das partículas serão descritos no capítulo de resultados. O objetivo da defasagem de 20 dias na execução das etapas foi verificar se ocorreriam mudanças significativas nas características do biofilme (na espessura, por exemplo) a ponto de serem notadas experimentalmente. Em cada etapa foram coletadas 10 partículas, com exceção da última, com 20 partículas.

Com exceção destes detalhes, a metodologia empregada para a determinação de $U_{t}$ das biopartículas foi a mesma descrita para as partículas inertes, ou seja, utilizando-se o ensaio de coluna.

\section{Equação de Richardson e Zaki:}

Em procedimento idêntico ao realizado para as partículas inertes, o parâmetro $\mathrm{n}$ da equação 3.6 foi obtido também para o leito com biopartículas. Dessa maneira, os valores obtidos para as velocidades terminais, conjuntamente com os ensaios fluidodinâmicos e os parâmetros da equação de Richardson \& Zaki, foi possível verificar a influencia da biomassa imobilizada no comportamento do leito. 


\subsection{DESEMPENHO DO REATOR A SEM PCP}

Após os ensaios fluidodinâmicos no reator $A$ com as partículas inertes, ele foi levado do Laboratório de Sistemas Particulados do DEQ - UFSCar para o LPB para dar início à fase biológica da pesquisa.

\subsubsection{PREPARAÇÃO DO LOCAL}

$O$ reator $A$ e os equipamentos periféricos foram montados em uma cabine térmica (Figura 4.12), adquirida em firma especializada ${ }^{12}$. O sistema experimental não ficou submetido a um controle rigoroso de temperatura, pois não foi utilizado qualquer tipo de dispositivo eletrônico (termostato, aquecimento, sistema refrigerador, dentre outros) de controle.

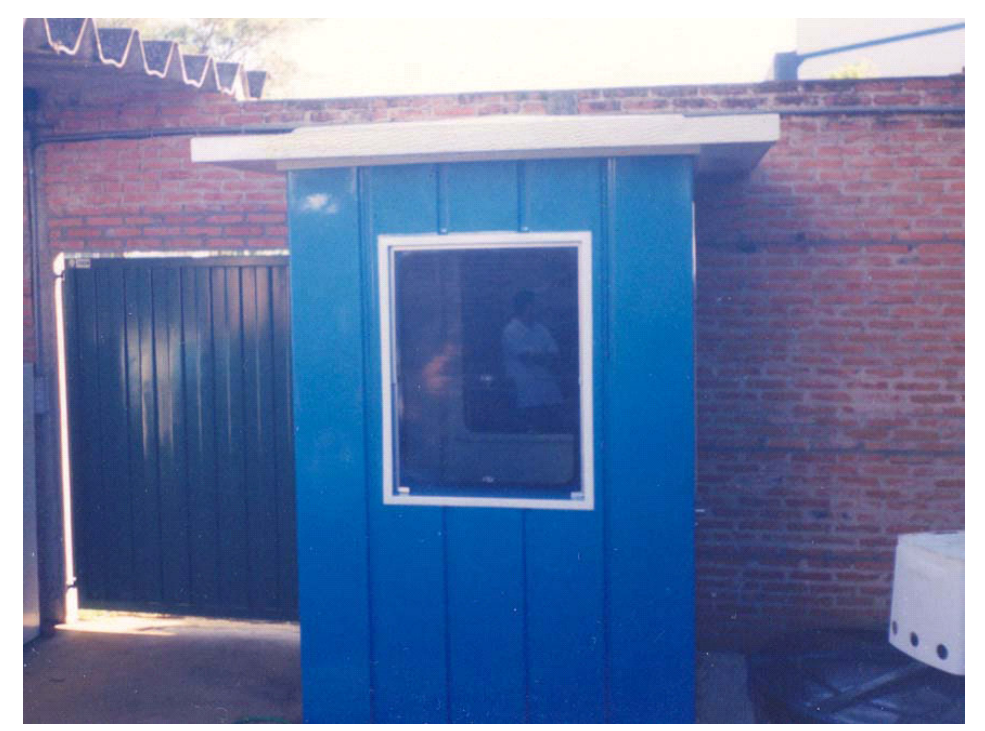

Figura 4.12 - Cabine térmica para abrigar o sistema experimental.

Como a cabine estava diretamente exposta aos raios solares, um material refletor / isolante térmico (Figura 4.13) foi colocado em suas paredes externas, para que dentro dela não fossem alcançadas temperaturas extremamente elevadas, que poderiam comprometer irreversivelmente a

\footnotetext{
${ }^{12}$ Guarita térmica de 1,50x1,50 com beiral perimetral de $30 \mathrm{~cm}$, transportada e montada em São Carlos - Marca Rentalbox (São Paulo - SP).
} 
atividade biológica da biomassa, e com isso prejudicar e até mesmo inutilizar o experimento.

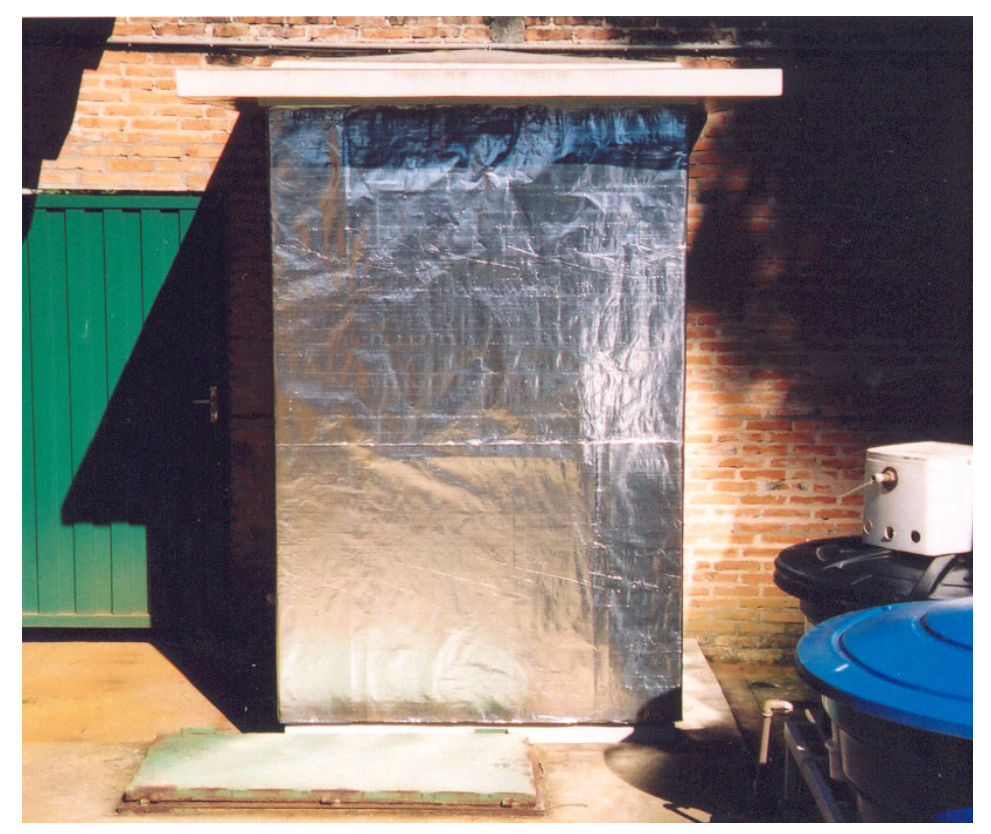

Figura 4.13 - Cabine térmica com refrator / isolamento térmico.

O monitoramento da temperatura pode ser dividido em duas fases distintas quanto à complexidade dos equipamentos. Inicialmente, na fase de operação do reator A sem PCP, a temperatura foi monitorada apenas com termômetros de mercúrio (tipo capela), de máxima e mínima, da marca OAKTON. Foram utilizados nesta fase dois termômetros, o primeiro localizado fora da cabine, para medir a temperatura externa, e o segundo, dentro da cabine, para medir a temperatura interna. Assim, através dessas medidas internas e externas, era possível verificar como a variação externa de temperatura foi "amortecida" no interior da cabine sem dispositivos eletrônicos de controle.

No entanto, justamente pela falta desses dispositivos de controle, percebeu-se que os efeitos da variação de temperatura ao longo do tempo exigiriam um monitoramento muito mais complexo do que aquele que foi disponibilizado, que registrava apenas as temperaturas máximas e mínimas diárias. Próximo ao início da etapa de introdução do PCP no reator, equipamentos para um monitoramento mais qualificado foram adquiridos, e 
serão descritos posteriormente, quando a introdução do PCP no sistema for abordada.

Finalizadas todas as atividades de preparação do local, o reator $A$ foi instalado dentro da cabine e preenchido com o material suporte que obteve os melhores resultados, segundo os critérios estabelecidos na etapa de avaliação. Ele foi inoculado e, terminado este processo, colocado nas condições normais de operação.

\subsubsection{PARÂMETROS OPERACIONAIS INICIAIS DO REATOR A}

Em reatores de leito fluidificado em escala de laboratório ou piloto, geralmente, a vazão de alimentação $\left(Q_{A}\right)$ é definida em função da adoção de um determinado tempo de detenção hidráulica $\left(\theta_{H}\right)$, e a vazão de recirculação $\left(Q_{R}\right)$ é aquela destinada a imprimir a fluidificação do leito.

Para a adoção de $\theta_{H}$ inicial, o critério estabelecido foi acompanhar valores da literatura, embora a faixa de valores encontrados tenha sido extremamente ampla. Os valores vão desde 5 dias (Tsuno et al., 1996) até cerca de 2 horas (Wilson et al, 1998). Optou-se por um $\theta_{H}$ de aproximadamente 13 horas, correspondente a uma vazão de alimentação de $30 \mathrm{~L} /$ dia.

O valor da vazão de recirculação é geralmente aquele capaz de imprimir uma determinada expansão do leito. Especificamente em reatores de leito fluidificado tratando clorofenóis, esses valores ficam normalmente na faixa de 25 a $35 \%$, segundo a literatura. Para a pesquisa, o valor adotado foi de $35 \%$. Assim, a velocidade de recirculação adotada foi àquela capaz de expandir o leito em aproximadamente $35 \%$. A altura de material suporte no leito adotada foi de $1 / 3$ da altura do leito, ou seja, $40 \mathrm{~cm}$. A alimentação do reator foi garantida por uma bomba dosadora solenóide marca Prominent, modelo Conb 1201 e a recirculação através de uma bomba centrífuga da marca MARK, modelo XD2, com motor de $1 / 2 \mathrm{CV}$.

Esses parâmetros foram adotados para os primeiros dias de operação do RALF, onde normalmente são respeitados certos limites de adaptação do reator. A intenção era diminuir o tempo de detenção hidráulica até valores ainda "executáveis" em escala de laboratório, e também chegar rapidamente 
ao valor final de DQO que foi previamente estabelecido, de $1000 \mathrm{mg} / \mathrm{L}$, e assim iniciar a etapa de introdução do PCP. A partir das condições iniciais, as variações dos parâmetros operacionais do reator foram determinadas de acordo com as respostas de desempenho obtidas, e por isso, serão apresentadas no capítulo de resultados.

\subsubsection{PROGRAMAÇÃO DAS ANÁLISES}

Além das análises de rotina para monitoramento $(\mathrm{pH}, \mathrm{DQO}$, alcalinidade e ácidos voláteis), e das análises de microscopia, foi estabelecido um perfil espacial (ao longo da altura) do reator A. Em reatores de mistura completa, os perfis espaciais são uma ferramenta eficiente para constatar se o reator está realmente com um comportamento típico (em situações ideais), ou seja, a concentração em qualquer ponto do reator é a mesma da saída. A Tabela 4.2 apresenta a freqüência mínima semanal das análises

Tabela 4.2 - Análises realizadas e freqüência mínima.

\begin{tabular}{lc}
\hline ANÁLISE & $\begin{array}{c}\text { FREQUENCIA } \\
\text { SEMANAL }\end{array}$ \\
\hline DQO & 2 \\
ÁCIDOS VOLÁTEIS & 2 \\
pH & 2 \\
ALCALINIDADE & 2 \\
\% DE METANO & 2 \\
ANÁLISE MICROBIOLÓGICA & ${ }^{*}$ \\
\hline \multicolumn{2}{c}{ Obs: $\left.{ }^{*}\right)-$ Ver explicação no texto. }
\end{tabular}

Além dos parâmetros descritos na Tabela 4.2, a quantidade de biomassa aderida ao material suporte foi verificada no final da operação do reator sem PCP e no final da operação do reator com PCP, através do método descrito por Chen \& Chen (2000).

A Tabela 4.3 mostra os métodos utilizados para a determinação dos parâmetros. Todas as análises foram realizadas seguindo os padrões descritos no Standard Methods for the Examination of Water and Wastewater (APHA, 1995) ou as metodologias próprias do LPB. As amostras do afluente e do efluente foram coletadas sempre por volta de 9:00 hs. 
Tabela 4.3 - Parâmetros físico-químicos que foram monitorados

\begin{tabular}{ll}
\hline \multicolumn{1}{c}{ PARÂMETROS } & \multicolumn{1}{c}{ MÉTODO } \\
\hline DQO afluente e efluente & $\begin{array}{l}\text { Espectrofotométrico, com refluxo } \\
\text { fechado, utilizando digestor } \\
\text { HACH-COD e espectrofotômetro } \\
\text { DR } 2000(\mathrm{HACH}) \text { a } 620\end{array}$ \\
\hline Ácidos voláteis afluente e efluente & Potenciométrico \\
\hline Concentração de metano no biogás & Cromatografia Gasosa com \\
& detector de condutividade térmica \\
& (CG/CT) \\
\hline pH afluente e efluente & Potenciométrico \\
\hline Biomassa imobilizada & Chen \& Chen (2000) \\
\hline Alcalinidade total e parcial do & Potenciométrico \\
afluente e efluente & \\
\hline
\end{tabular}

As amostras de partículas para estimativa da quantidade de biomassa aderida ao suporte, bem como para as análises microbiológicas, foram retiradas sempre do mesmo ponto, através de um amostrador distante $20 \mathrm{~cm}$ do fundo do reator. Na Figura 4.14, esse amostrador está localizado à esquerda, enquanto à direita estão distribuídos os outros amostradores para o perfil ao longo da altura.

A morfologia dos microrganismos foi analisada através de microscopia óptica e por microscopia eletrônica de varredura (MEV). A microscopia óptica foi realizada no início da operação do reator $A$ sem PCP, no final da operação do reator $A$ sem $P C P$, e também no final da operação do reator A com PCP. A $M E V$ foi realizada no final da operação do reator $A$ sem PCP e também no final da operação do reator A com PCP. 


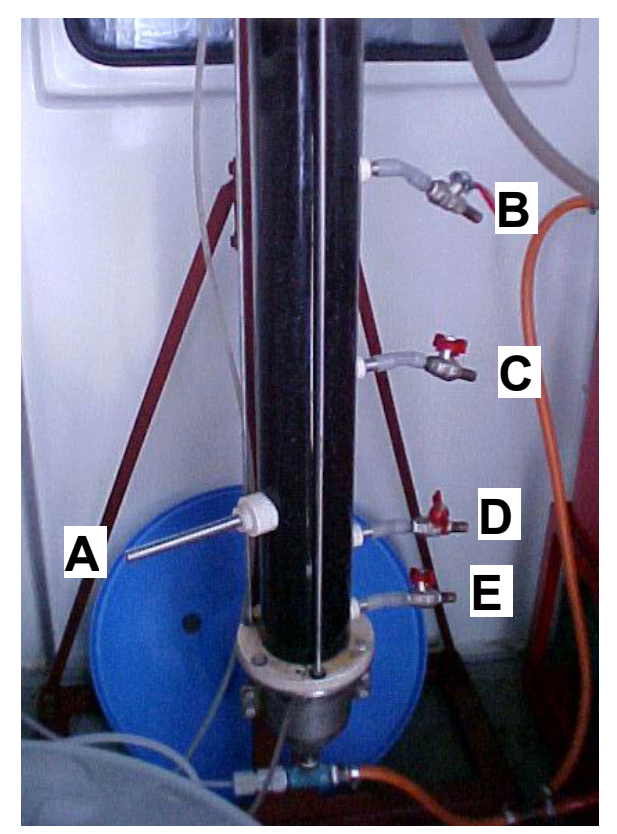

Figura 4.14 - Amostradores para os perfis do reator $A$.

Amostrador A: para coleta de biopartículas --- Amostradores B, C, D e E: para coleta de amostras do líquido ao longo da altura do reator.

\subsubsection{MICROSCOPIA ÓPTICA}

Todas as análises de microscopia óptica foram realizadas no $\mathrm{LPB}^{13}$, nas biopartículas do melhor material suporte, durante três diferentes épocas de operação do reator $A$, em microscópio Leica modelo DMLB com aumento de 1500 vezes.

Foram utilizadas duas técnicas de preparação das amostras (informação verbal) ${ }^{14}$ : raspagem das biopartículas e agitação.

Uma parte das biopartículas retiradas dos reatores foi colocada em vidros de relógio e sofreu uma raspagem, com auxílio de uma agulha de seringa. Com auxílio de um conta-gotas, o material raspado foi colocado nas lamínulas com gel ágar e levado ao microscópio para observação.

$\mathrm{Na}$ técnica de agitação, cerca de 20 biopartículas foram colocadas em um frasco de antibiótico de $50 \mathrm{~mL}$, contendo cerca de $30 \mathrm{~mL}$ de efluente e algumas gotas de Tween 80, um detergente utilizado para potencializar 0 desprendimento da biomassa . O frasco foi fechado com tampas de borracha e

\footnotetext{
${ }^{13}$ Pela ecóloga e técnica do LPB, Dra. Eloísa Pozzi.

${ }^{14}$ Amostras preparadas pelo próprio pesquisador, sob orientação da Dra. Eloísa Pozzi.
} 
agitado manualmente por cerca de 10 minutos. A fase líquida era colocada em eppendorfs e centrifugada por 2 minutos para separação das fases sólida e líquida. A fase sólida era coletada com auxílio de conta-gotas e colocada em lamínulas com gel ágar para observação em microscópio. A coleta das amostras foi feita nos mesmos dias de análise, para garantir resultados mais realistas, pois o emprego de técnicas de preservação poderia comprometer a integridade da amostra.

\subsubsection{MICROSCOPIA ELETRÔNICA DE VARREDURA (MEV)}

A MEV das partículas inertes, na fase de avaliação dos suportes, foi realizada no CCDM (UFSCar) e não necessitou de preparação das amostras. A MEV das biopartículas, para acompanhamento do desenvolvimento do biofilme, foi realizada no Instituto de Física de São Carlos (USP), em microscópio da marca Zeiss, modelo DSM-960 em $20 \mathrm{KV}$ e fotografadas com um vídeo processador de cópias Mitsubishi, com chapa fotográfica Fuji CK $100 \mathrm{~s}$. A MEV exigia um tratamento prévio, que aconteceu nas dependências do LPB.

Inicialmente as amostras (colocadas em pequenos tubos de ensaio) foram fixadas em solução de glutaraldeído (Sigma-Aldrich) 2,5\% em tampão fosfato $0,1 \mathrm{M}(\mathrm{pH} 7,3)$ por um período mínimo de $12 \mathrm{hs}$, à temperatura de $4^{\circ} \mathrm{C}$. Após a fixação, o material foi desidratado em uma série gradativa de álcool etanol em diversas concentrações vol $/$ vol $(50 \%, 60 \%, 70 \%, 80 \%, 90 \%, 95 \%$ e $100 \%$ ), permanecendo por 10 minutos em cada concentração. Repetiu-se a desidratação em álcool $100 \%$ por mais duas vezes. Após a desidratação, as amostras foram colocadas em estufa a $30^{\circ} \mathrm{C}$ por cerca de 20 minutos. Secas, as amostras foram fixadas em suportes específicos de alumínio por base incolor de esmalte e levadas ao Instituto de Física. Antes de serem analisadas, as amostras foram recobertas por uma camada de ouro $(99,99 \%)$ em um metalizador. As amostras para a MEV foram coletadas e preparadas na véspera da análise.

A metodologia para a MEV, colocada aqui de forma resumida, foi descrita com detalhes no trabalho de Araújo (1995). 


\subsection{DESEMPENHO DO RALF A COM O PCP}

Antes da introdução do PCP no reator $A$, foram adquiridos e instalados alguns equipamentos indispensáveis para proporcionar um monitoramento mais qualificado da variação de temperatura. Três termopares tipo "T" (Figura 4.15), de cobre/constantan (marca SALCA) foram colocados respectivamente no ambiente externo à cabine, no ambiente interno e dentro do reator, permitindo assim que as temperaturas externas, internas e do líquido fossem monitoradas.

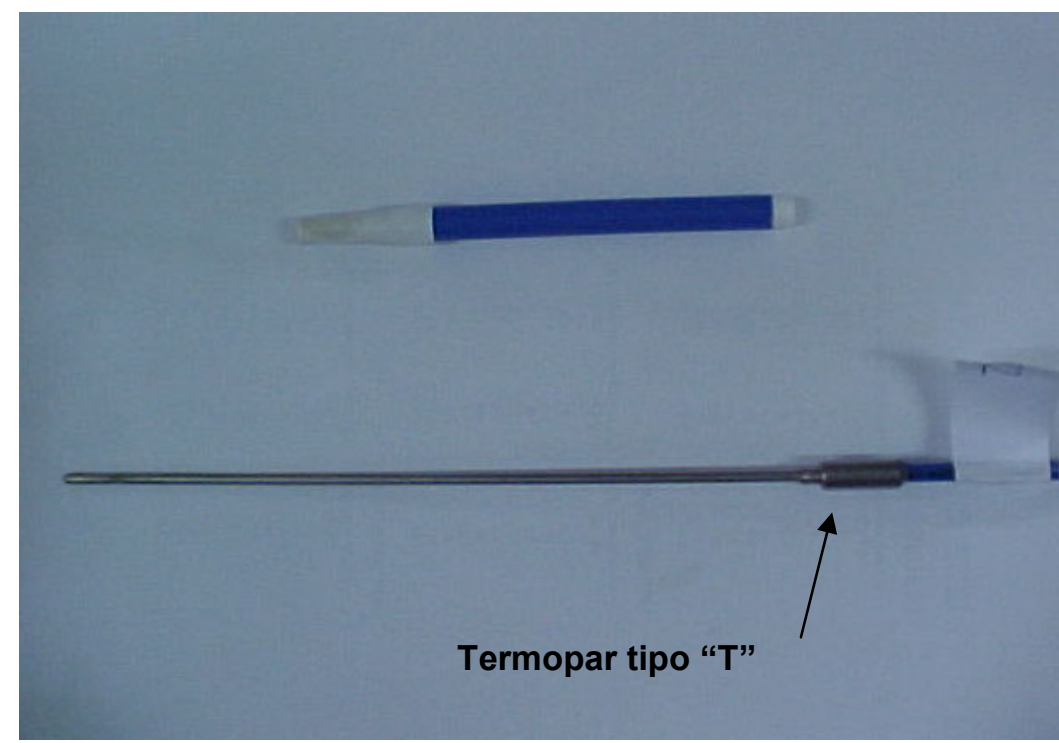

Figura 4.15 - Termopar tipo "T" utilizado no monitoramento das temperaturas.

Para armazenar as informações, os termopares foram conectados através de cabos especiais a uma central de registro de dados ("data logger") de 12 canais, da marca Cole-Parmer (Figura 4.16) com capacidade para registrar até 255 dados por canal. Antes de ser esgotada a memória de armazenamento, a central (de fácil manuseio) era levada e conectada a um microcomputador para transferência dos dados registrados.

O equipamento permitia registrar as temperaturas de até 4 em 4 segundos, porém, inicialmente neste trabalho, as temperaturas foram registradas de 10 em 10 minutos com transferência diária de dados para o microcomputador. Após um período de observação do comportamento da 
variação, verificou-se que o registro poderia ser feito de 30 em 30 minutos. Com essa nova freqüência de registros, a transferência de dados para o computador foi feita de 5 em 5 dias.

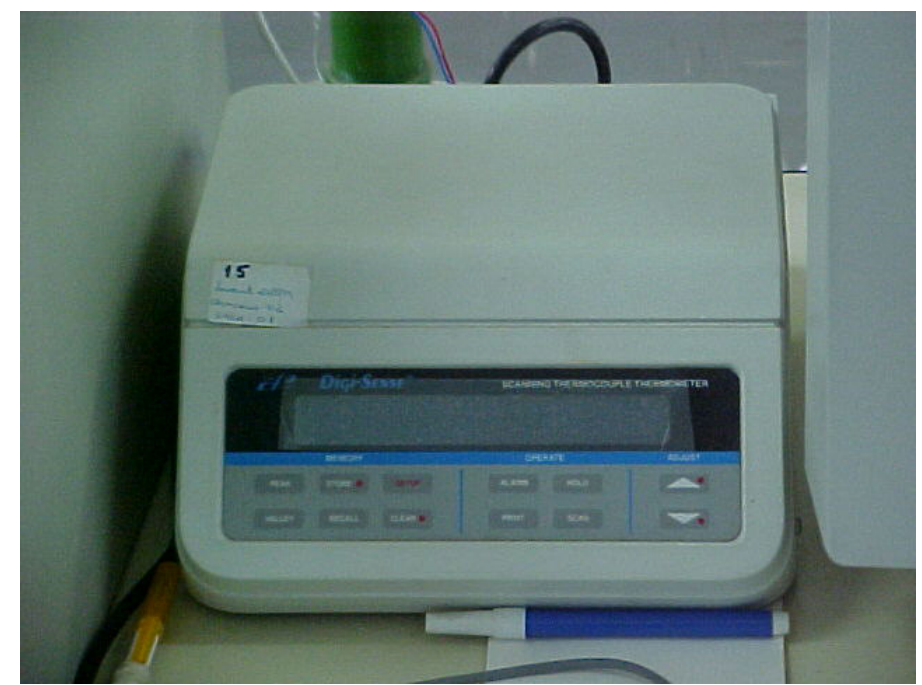

Figura 4.16 - Central de registro de dados conectada ao microcomputador.

\subsubsection{PREPARAÇÃO DA SOLUÇÃO ESTOQUE DE PCP}

O PCP é um pó branco extremamente insolúvel em água, mas existem maneiras relativamente simples de se preparar uma solução estoque. Uma das maneiras utilizadas é dissolvê-lo em álcoois, como por exemplo o etanol e o metanol (DAMIANOVIC, 1997; OLIVEIRA, 1998; BARALDI, 2001), e outra maneira é fazer a solução em pH elevado. Para não introduzir uma outra fonte de carbono ao reator, já que a idéia era utilizar a glicose como fonte única, a solução de PCP foi elaborada em pH elevado, com auxílio de hidróxido de sódio $(\mathrm{NaOH})$. O PCP foi pesado em balança de alta precisão $\left(10^{-5} \mathrm{~g}\right)$ e colocado em um béquer com água destilada, e o hidróxido de sódio foi acrescentado aos poucos, sob agitação com bastão de vidro, até a dissolução completa dos sólidos.

Dessa maneira foi elaborada uma solução estoque de $7 \mathrm{~g} / \mathrm{L}$ de PCP que foi acrescentada ao afluente, de maneira a resultar nas concentrações desejadas para aplicar ao RALF. Não foi necessária a correção do pH em virtude dos elevados volumes que foram utilizados. 


\subsubsection{CONDIÇÕES OPERACIONAIS DO REATOR COM PCP}

Atingidas as condições operacionais estabelecidas previamente para o reator $A$ (DQO afluente de $1000 \mathrm{mg} / \mathrm{L}$ e $\theta_{H}$ final), o PCP foi introduzido no sistema inicialmente na concentração de $1 \mathrm{mg} / \mathrm{L}$.

Na seqüência da operação, foram aplicadas concentrações de 2, 4 e 6 $\mathrm{mg} / \mathrm{L}$. Essas concentrações são semelhantes às que foram utilizadas em pesquisas anteriores do LPB (DAMIANOVIC, 1997; OLIVEIRA, 1998; LARIZZATTI, 1997; BARALDI, 2001), e estão compatíveis com o objetivo do trabalho, que era verificar a remoção de um composto tóxico com o reator operando em condições menos idealizadas.

\subsubsection{PROGRAMAÇÃO DAS ANÁLISES}

As análises programadas para a etapa do reator A operando com o PCP foram as mesmas descritas na Tabela 4.2 com o acréscimo da análise de cromatografia para a determinação da concentração de PCP afluente e efluente. A freqüência mínima de coleta de amostras para análises da concentração de PCP foi de duas vezes por semana.

\subsubsection{PRESERVAÇÃO DAS AMOSTRAS}

As amostras coletadas para determinação da concentração de PCP foram guardadas em tubos de DQO e colocadas no freezer, sendo que as análises foram realizadas quando foi atingido um número considerável de amostras (geralmente 12).

Damianovic (1997), em seu trabalho pioneiro, fez uma série de verificações muito úteis aos trabalhos posteriores. A pesquisadora verificou que o armazenamento das amostras do PCP no freezer não acarretaria qualquer problema de alteração dos resultados, danificação nas amostras e integridade das análises. 


\subsubsection{ANÁLISE DA CONCENTRAÇÃO DE PCP}

Por se tratar de uma ferramenta de auxílio para cumprir os objetivos propostos, e não finalidade principal do trabalho, a metodologia para determinação da concentração de PCP será descrita aqui de forma resumida, pois foi utilizado processo desenvolvido por outros pesquisadores do LPB (informação verbal) $^{15}$. Neste trabalho, a determinação da concentração de PCP foi obtida mediante análise de cromatografia gasosa, em cromatógrafo HP 5890 , com temperatura do injetor de $250^{\circ} \mathrm{C}$, do detector de $320^{\circ} \mathrm{C}$, inicial do forno de $45^{\circ} \mathrm{C}$ e final de $260^{\circ} \mathrm{C}$.

\subsubsection{PREPARAÇÃO DA AMOSTRA}

A amostra de PCP sofreu um processo de derivatização. Este processo, baseando-se em uma explicação simplificada, consiste em transformar um composto químico em outro, através de um agente derivatizante, para viabilizar a sua determinação. Uma revisão minuciosa sobre vários processos de derivatização de clorofenóis para a realização de análises cromatográficas pode ser encontrada em Damianovic (1997). O processo de preparação das amostras, feito em capela, consistiu na seguinte seqüência:

1) as amostras que estavam no freezer foram descongeladas em temperatura ambiente;

2) colocou-se $1 \mathrm{~mL}$ de amostra em um tubo de $\mathrm{DQO}$;

3) acrescentou-se $250 \mu \mathrm{L}$ de carbonato de potássio $\left(\mathrm{K}_{2} \mathrm{CO}_{3}\right)$;

4) acrescentou-se $50 \mu \mathrm{L}$ de padrão interno. Como padrão interno foi utilizado o 2,4 dibromofenol;

5) acrescentou-se $375 \mu \mathrm{L}$ de anidrido acético como agente derivatizante;

6) acrescentou-se $0,5 \mu \mathrm{L}$ de hexano ultra-puro;

7) agitou-se cada tubo por 1 minuto, em agitador de tubos (vórtex) marca PHOENIX, modelo AP 56, em velocidade máxima;

\footnotetext{
${ }^{15}$ A metodologia foi desenvolvida, e explicada pessoalmente, pela doutoranda Flavia Talarico Saia, cujo trabalho está em andamento.
} 
8) em seguida os tubos foram colocados no freezer para aguardar o momento de injetar as amostras;

9) posteriormente foi injetado $1 \mu \mathrm{L}$ no cromatógrafo.

\subsubsection{DESCRIÇÃO DA ANÁLISE}

A análise de cromatografia, após a injeção da amostra, teve duração de aproximadamente 26 minutos. As "curvas padrão", com concentrações conhecidas, foram realizadas por outros pesquisadores, para os seguintes clorofenóis: 2,3 diclorofenol; 2,6 diclorofenol; 2,4,6 triclorofenol; 2,3,6 triclorofenol; 2,3,4 triclorofenol e pentaclorofenol. A Tabela 4.4 mostra os tempos de retenção para cada composto durante a analise de cromatografia.

Tabela 4.4 - Tempos de retenção para os clorofenóis padronizados.

\begin{tabular}{cc}
\hline Analitos & Tempo de retenção (min) \\
\hline 2,3 diclorofenol & 12,1 \\
2,6 diclorofenol & 12,9 \\
2,4,6 triclorofenol & 14,2 \\
2,3,6 triclorofenol & 15,1 \\
2,4 dibromofenol (padrão & 15,9 \\
interno) & 16,3 \\
2,3,4 triclorofenol & 22,1 \\
PCP &
\end{tabular}

Portanto, para uma amostra qualquer, era possível identificar os compostos através dos "picos" e de seus respectivos tempos de retenção. Um "pico" após 22,1 minutos de processamento, indicava a presença de PCP na amostra, e assim por diante. $\mathrm{O}$ "pico" do padrão interno, por exemplo, aparecia após 15,9 minutos de processamento.

${ }^{16}$ Material gentilmente cedido pela doutoranda Flavia Talarico Saia. 


\subsubsection{DETERMINAÇÃO DA CONCENTRAÇÃO DE PCP}

De posse desses resultados, e também da curva de calibração, foi possível calcular a concentração de PCP da amostra. A Figura 4.17 mostra a curva de calibração do PCP e dos outros clorofenóis descritos na Tabela 4.4.
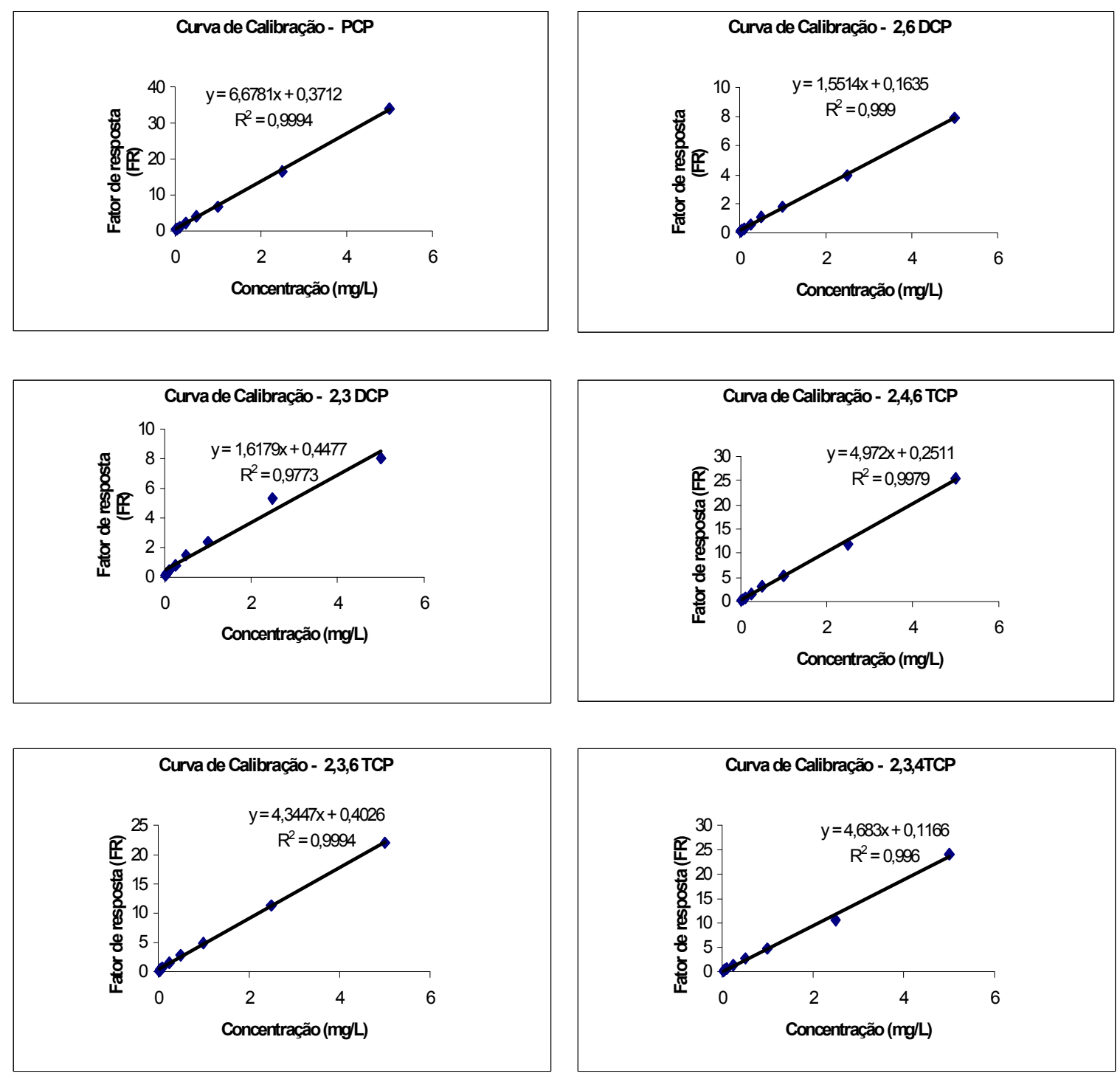

Figura 4.17 - Curvas de calibração para os compostos padronizados, na concentração de 0 a $5 \mathrm{mg} / \mathrm{L}$.

Através do comando "integrate" no software do microcomputador associado ao cromatógrafo, foi possível integrar as áreas dos "picos" de cada composto. A partir da área obtida para o clorofenol desejado, por exemplo o PCP, e da área do padrão interno, era calculado o Fator de Resposta (FR). $O$ 
Fator de resposta é definido como a razão entre a área do clorofenol desejado e a área do padrão interno, o 2,4 dibromofenol. De posse de FR e da curva de calibração, era finalmente obtida a concentração de PCP.

\subsubsection{CUIDADOS COM A SEGURANÇA}

Além dos cuidados rotineiros de pesquisas em laboratórios, tais como a utilização de jaleco e luvas, foi utilizada a capela para a preparação da solução estoque de PCP, bem como para a derivatização das amostras para análise no cromatógrafo.

\subsubsection{CUIDADOS DURANTE A ROTINA EXPERIMENTAL}

O pesquisador trabalhou com dois reservatórios afluentes, com capacidade de 100 litros cada. Cada um foi lavado dia sim dia não. As mangueiras de sucção e recalque das bombas eram limpas a cada 30 dias. 


\section{RESULTADOS}

\subsection{CONSIDERAÇÕES GERAIS}

Neste capítulo os resultados foram apresentados obedecendo a mesma ordem da metodologia do trabalho. Quando a avaliação de etapas interligadas foi necessária, como por exemplo quando foi comparada a fluidodinâmica do reator com partículas inertes e biopartículas, ítens complementares de discussão foram acrescentados.

\subsection{AVALIAÇÃO DAS PARTíCULAS PARA ESCOLHA DO MELHOR MEIO SUPORTE}

A seguir são apresentados os resultados das análises de determinação das principais propriedades físicas, da estrutura em escala microscópica, dos aspectos geométricos das partículas inertes, além dos ensaios de fluidodinâmica e de imobilização de biomassa. Todos esses ensaios fizeram parte da etapa de avaliação dos três materiais suporte e forneceram informações para a escolha do melhor material.

\subsubsection{CARACTERIZAÇÃO DAS PARTÍCULAS}

As análises de caracterização foram as seguintes: porosimetria de mercúrio (densidade, densidade aparente, área total de poros, diâmetro médio de poros e porosidade), adsorção e condensação de nitrogênio (área específica), microscopia eletrônica de varredura (MEV) e análise de imagem (imagem das partículas e diâmetro máximo, mínimo e médio de cada partícula). 


\subsubsection{POROSIMETRIA DE MERCÚRIO E BET}

Para facilitar a comparação, os resultados de porosimetria de mercúrio e BET para os três materiais foram agrupados em uma única Tabela, apresentada a seguir (Tabela 5.1).

Tabela 5.1 - Propriedades obtidas para os três materiais em análises de porosimetria de mercúrio e BET.

\begin{tabular}{lccc}
\hline PROPRIEDADE & ALUMINA & BASALTO & CARVÃO \\
\hline Densidade da partícula $\left(\mathrm{g} / \mathrm{cm}^{3}\right)$ & 1,32 & 2,78 & 0,93 \\
Densidade aparente $\left(\mathrm{g} / \mathrm{cm}^{3}\right)$ & 1,75 & 2,85 & 1,21 \\
Área total de poros $\left(\mathrm{m}^{2} / \mathrm{g}\right)$ & 43,69 & 1,74 & 19,32 \\
Diâmetro médio de poro $(\mu \mathrm{m})$ & 0,02 & 1,00 & 0,09 \\
Porosidade $(\%)$ & 24,5 & 2,6 & 22,5 \\
Área específica $\left(\mathrm{m}^{2} / \mathrm{g}\right)$ & 227,90 & 17,56 & 68,44 \\
\hline
\end{tabular}

Os resultados da Tabela 5.1 mostram que o basalto analisado possuía uma densidade $(2,78)$ bem mais elevada que a alumina e o carvão $(1,32$ e 0,93 respectivamente) e uma porosidade de partícula extremamente baixa $(2,6 \%)$ em comparação à alumina $(24,5 \%)$ e ao carvão $(22,5 \%)$, comprovada também no valor obtido para área total de poros $\left(1,74 \mathrm{~m}^{2} / \mathrm{g}\right)$. Apesar das porosidades similares entre a alumina e o carvão, a área total de poros e a área específica da alumina foram aproximadamente duas e três vezes maior que a do carvão, respectivamente. No entanto, o diâmetro dos poros do carvão analisado $(0,09$ $\mu \mathrm{m})$ era mais de 4 vezes maior que o da alumina $(0,02 \mu \mathrm{m})$.

Os parâmetros físicos obtidos serão retomados na discussão de outros resultados, bem como na avaliação geral dos materiais suportes. A posse apenas dos resultados de caracterização física não permitiu qualquer especulação sobre o melhor material. 


\subsubsection{MICROSCOPIA ELETRÔNICA DE VARREDURA DAS PARTÍCULAS INERTES}

As Figuras 5.1 e 5.2 apresentam, respectivamente, imagens (micrografia) da microscopia eletrônica de varredura da partícula de basalto e de alumina.

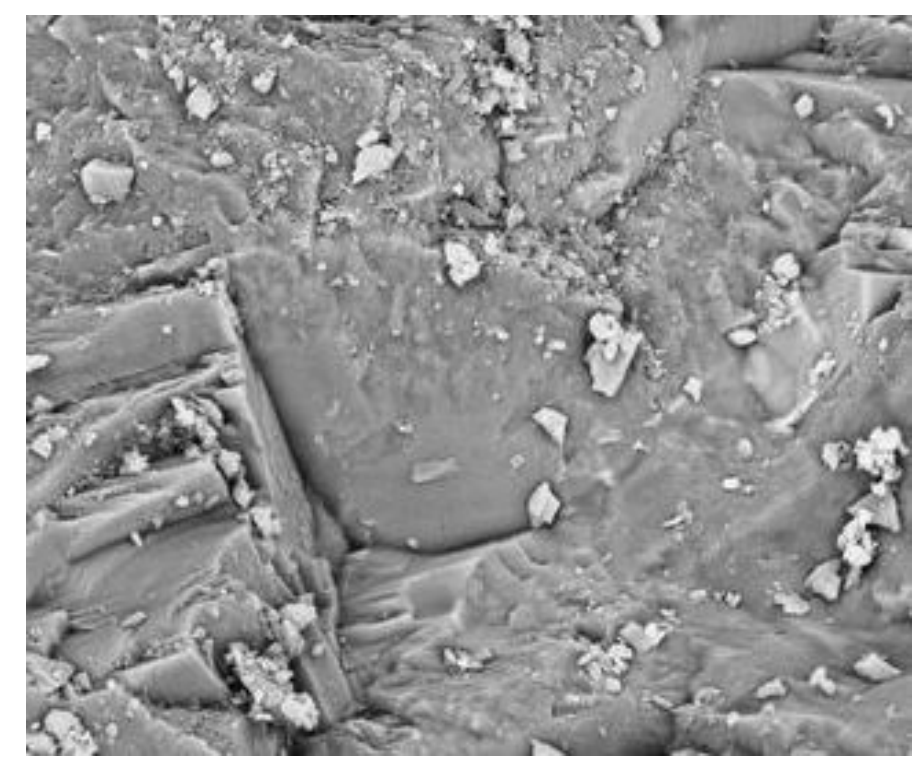

Figura 5.1 - Micrografia obtida via MEV da partícula de basalto.

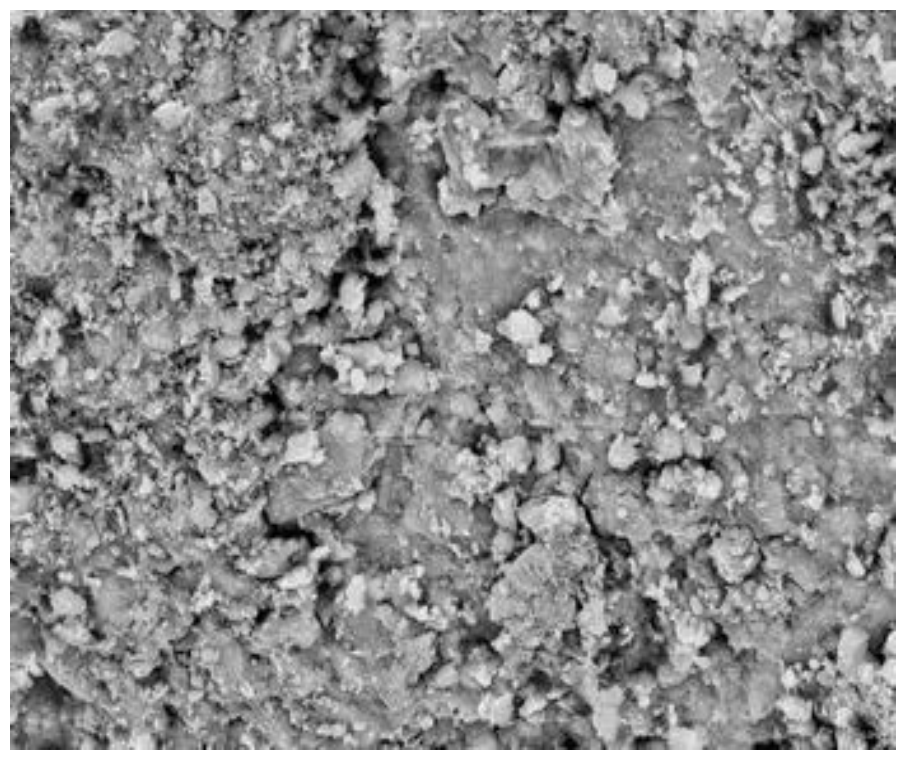

Figura 5.2 - Micrografia obtida via MEV da partícula de alumina. 
A estrutura mostrada na Figura 5.1 comprova claramente que a partícula de basalto é maciça, motivo pela qual uma elevada densidade foi obtida na caracterização física. Além disso, a partícula é relativamente plana e praticamente sem poros, também de acordo com os resultados de porosidade obtidos na caracterização física. Na micrografia da partícula de alumina (Figura 5.2), observa-se uma estrutura heterogênea e com a existência de vazios (correspondendo aos pontos mais escuros) que caracterizam a porosidade da partícula.

A micrografia da partícula de carvão ativado (Figura 5.3), realizada na mesma escala que a da partícula de alumina, retrata exatamente a grande diferença entre o tamanho dos poros, também confirmada pelos ensaios de caracterização física.

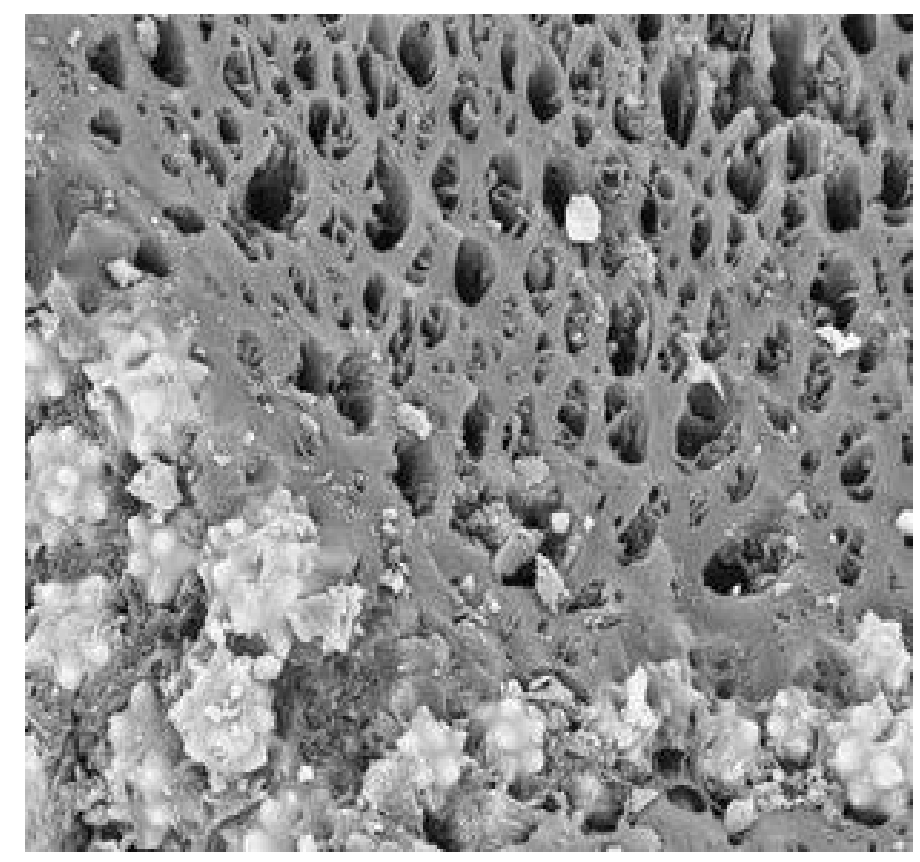

Figura 5.3 - Micrografia obtida via MEV da partícula de carvão ativado.

\subsubsection{ANÁLISE DE IMAGEM}

Como a faixa granulométrica das partículas de carvão ativado e basalto era extensa, foi feita uma seleção prévia de diâmetros através de peneiramento. E os diâmetros analisados são mostrados na Tabela 5.2. 
Tabela 5.2 - Partículas utilizadas na análise de imagem, seus diâmetros e metodologia de seleção desses diâmetros.

\begin{tabular}{ccc}
\hline PARTÍCULA & DIÂMETRO $(\mathbf{m m})$ & METODOLOGIA \\
\hline ALUMINA & 3,5 & Fabricante \\
BASALTO & 3,08 & Peneiramento $^{*}$ \\
CARVÃO ATIVADO & 2,16 e 3,08 & Peneiramento $^{*}$ \\
\hline Obs.: $\left(^{*}\right.$ ) diâmetro médio de peneira &
\end{tabular}

\section{ALUMINA}

A Figura 5.4 mostra a imagem do grupo de partículas de alumina analisadas. Apesar de aparecerem escuras na imagem, as partículas eram originalmente brancas (Figura 5.5).

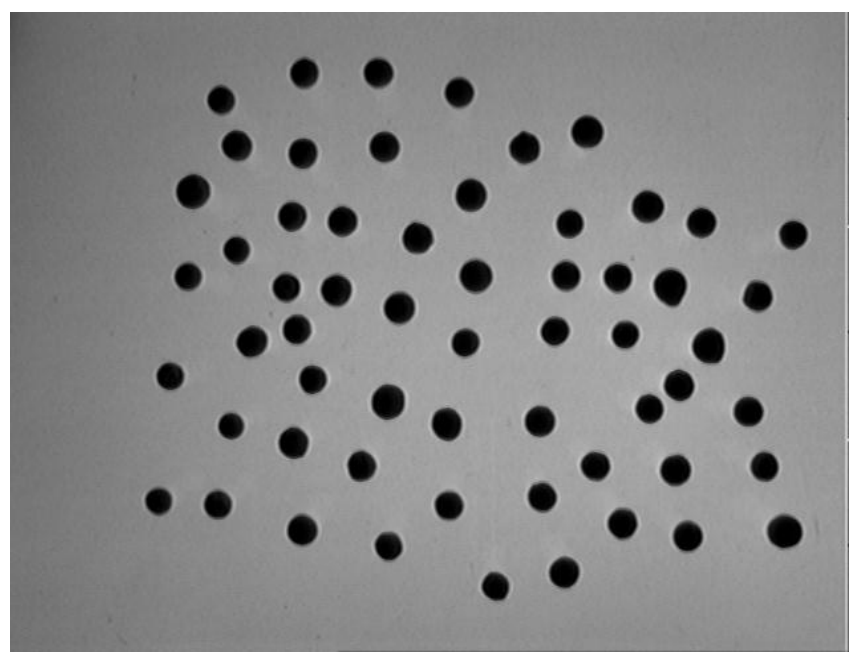

Figura 5.4 - Imagem registrada das partículas de alumina analisadas.

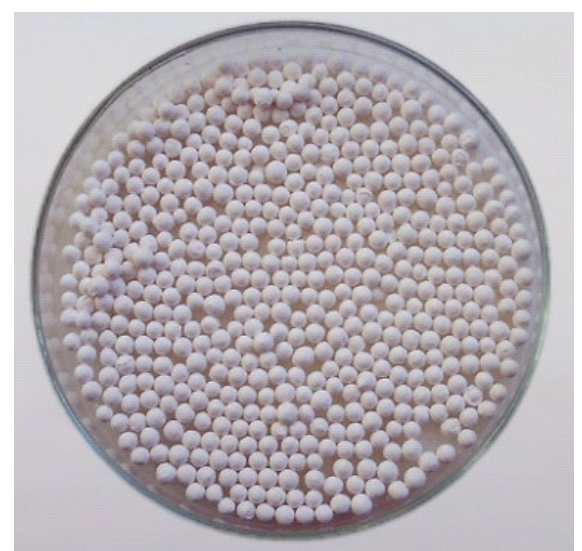

Figura 5.5 - Partículas de alumina 
A Tabela 5.3 mostra os resultados indicados pelo software Image Pro Plus para a análise dos diâmetros de cada partícula do grupo de 59 partículas de alumina selecionado. A primeira coluna indica o diâmetro máximo de cada partícula, a segunda coluna indica o diâmetro mínimo de cada partícula e a terceira coluna mostra o diâmetro médio da partícula analisada.

Tabela 5.3 - Análise do software Image Pro Plus para o diâmetro máximo, mínimo e médio de cada partícula de alumina analisada.

\begin{tabular}{|c|c|c|c|c|c|c|c|}
\hline partícula & $\begin{array}{c}\text { diâmetro } \\
\text { máximo } \\
(\mathrm{mm})\end{array}$ & $\begin{array}{c}\text { diâmetro } \\
\text { mínimo } \\
(\mathrm{mm})\end{array}$ & $\begin{array}{c}\text { diâmetro } \\
\text { médio } \\
(\mathrm{mm})\end{array}$ & partícula & $\begin{array}{c}\text { diâmetro } \\
\text { máximo } \\
(\mathrm{mm})\end{array}$ & $\begin{array}{c}\text { diâmetro } \\
\text { mínimo } \\
(\mathrm{mm})\end{array}$ & $\begin{array}{c}\text { diâmetro } \\
\text { Médio } \\
(\mathrm{mm})\end{array}$ \\
\hline & & & & 30 & 3,40 & 3,11 & 3,25 \\
\hline 1 & 3,56 & 3,28 & 3,40 & 31 & 3,28 & 2,97 & 3,10 \\
\hline 2 & 3,53 & 3,17 & 3,39 & 32 & 3,69 & 3,43 & 3,55 \\
\hline 3 & 3,48 & 3,28 & 3,41 & 33 & 4,25 & 3,73 & 3,96 \\
\hline 4 & 3,52 & 3,14 & 3,26 & 34 & 3,32 & 3,00 & 3,16 \\
\hline 5 & 3,85 & 3,59 & 3,77 & 35 & 3,24 & 3,04 & 3,18 \\
\hline 6 & 3,69 & 3,35 & 3,55 & 36 & 3,37 & 3,06 & 3,22 \\
\hline 7 & 3,69 & 3,35 & 3,55 & 37 & 3,70 & 3,35 & 3,51 \\
\hline 8 & 3,76 & 3,40 & 3,58 & 38 & 4,20 & 3,81 & 3,99 \\
\hline 9 & 3,64 & 3,22 & 3,46 & 39 & 3,52 & 3,04 & 3,26 \\
\hline 10 & 4,18 & 3,84 & 4,00 & 40 & 3,58 & 3,32 & 3,43 \\
\hline 11 & 3,87 & 3,48 & 3,72 & 41 & 3,69 & 3,44 & 3,54 \\
\hline 12 & 3,85 & 3,58 & 3,71 & 42 & 3,98 & 3,43 & 3,64 \\
\hline 13 & 3,48 & 3,14 & 3,32 & 43 & 3,07 & 2,79 & 2,98 \\
\hline 14 & 3,56 & 3,29 & 3,43 & 44 & 3,80 & 3,28 & 3,52 \\
\hline 15 & 3,54 & 3,27 & 3,41 & 45 & 3,56 & 3,14 & 3,34 \\
\hline 16 & 3,32 & 3,04 & 3,16 & 46 & 3,48 & 3,18 & 3,30 \\
\hline 17 & 3,37 & 3,06 & 3,26 & 47 & 3,52 & 3,00 & 3,27 \\
\hline 18 & 3,70 & 3,47 & 3,56 & 48 & 3,68 & 3,35 & 3,53 \\
\hline 19 & 3,18 & 2,85 & 3,05 & 49 & 3,54 & 3,14 & 3,28 \\
\hline 20 & 3,96 & 3,66 & 3,77 & 50 & 3,20 & 2,91 & 3,09 \\
\hline 21 & 3,44 & 3,14 & 3,28 & 51 & 3,35 & 3,04 & 3,22 \\
\hline 22 & 3,27 & 2,95 & 3,12 & 52 & 3,43 & 3,11 & 3,26 \\
\hline 23 & 3,32 & 3,11 & 3,22 & 53 & 3,48 & 3,32 & 3,41 \\
\hline 24 & 4,45 & 3,73 & 3,99 & 54 & 3,61 & 3,35 & 3,49 \\
\hline 25 & 3,32 & 3,06 & 3,21 & 55 & 4,20 & 3,64 & 3,98 \\
\hline 26 & 3,68 & 3,44 & 3,57 & 56 & 3,54 & 3,28 & 3,43 \\
\hline 27 & 3,61 & 3,24 & 3,41 & 57 & 3,37 & 2,95 & 3,17 \\
\hline 28 & 3,75 & 3,40 & 3,59 & 58 & 3,67 & 3,35 & 3,51 \\
\hline 29 & 3,44 & 3,18 & 3,31 & 59 & 3,48 & 3,00 & 3,20 \\
\hline
\end{tabular}

A realização deste ensaio foi muito interessante e conveniente porque permitiu, para cada lote analisado, o cálculo da média dos três diâmetros apresentados, e que forneceram subsídios essenciais para analisar a similaridade entre as partículas, ou seja: 


\section{$\overline{\mathrm{d}}_{\max }$ : média dos diâmetros máximos das partículas $(\mathrm{mm})$; \\ $\overline{\mathrm{d}}_{\min }$ : média dos diâmetros mínimos das partículas $(\mathrm{mm})$; \\ $\overline{\mathrm{d}}_{\text {med }}$ : média dos diâmetros médios das partículas $(\mathrm{mm})$;}

Para o lote de 59 partículas de alumina analisado, foram obtidas as seguintes médias com seus respectivos desvios:

$$
\begin{aligned}
& \overline{\mathrm{d}}_{\text {max }}=(3,60 \pm 0,28) \mathrm{mm} \\
& \overline{\mathrm{d}}_{\text {min }}=(3,26 \pm 0,24) \mathrm{mm} \\
& \overline{\mathrm{d}}_{\text {med }}=(3,43 \pm 0,25) \mathrm{mm}
\end{aligned}
$$

Pode-se notar que a média dos diâmetros médios das partículas foi bem próxima do valor fornecido pelo fabricante $(3,5 \mathrm{~mm})$, e os três valores médios foram muito próximos. Quanto mais próximos forem esses valores, e menores os desvios, mais esféricas e semelhantes umas às outras serão as partículas.

\section{BASALTO}

A Figura 5.6 mostra a imagem do grupo de partículas de basalto analisadas.

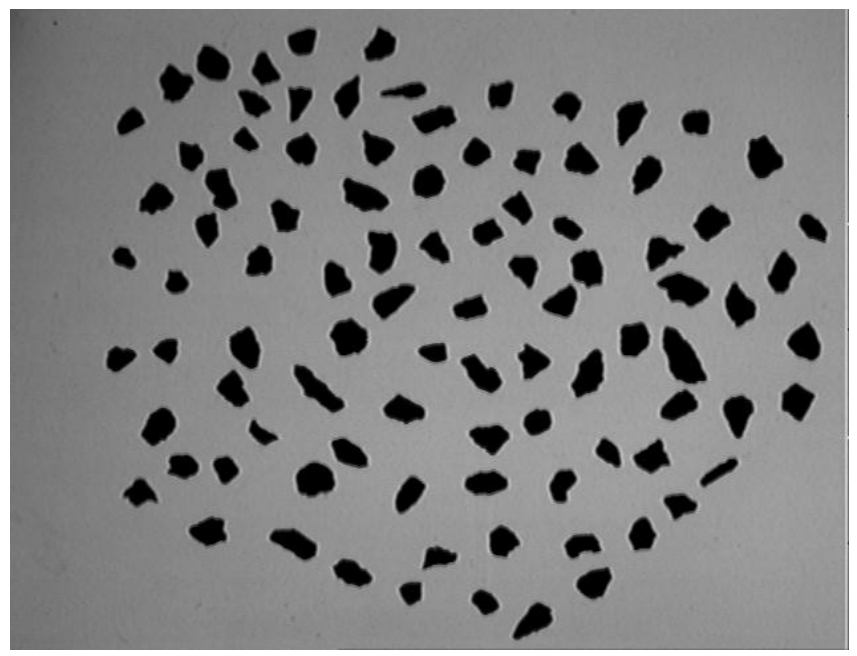

Figura 5.6 - Imagem registrada das partículas de basalto analisadas. 
A Tabela 5.4 mostra os resultados indicados pelo software Image Pro Plus para a análise dos diâmetros de cada partícula do grupo de 84 partículas de basalto selecionado.

Tabela 5.4 - Análise do software Image Pro Plus para o diâmetro máximo, mínimo e médio de cada partícula de basalto analisada.

\begin{tabular}{|c|c|c|c|c|c|c|c|}
\hline partícula & $\begin{array}{c}\text { Diâmetro } \\
\text { máximo } \\
(\mathrm{mm})\end{array}$ & $\begin{array}{c}\text { Diâmetro } \\
\text { mínimo } \\
(\mathrm{mm})\end{array}$ & $\begin{array}{c}\text { Diâmetro } \\
\text { médio } \\
(\mathrm{mm})\end{array}$ & partícula & $\begin{array}{l}\text { Diâmetro } \\
\text { máximo } \\
(\mathrm{mm})\end{array}$ & $\begin{array}{c}\text { Diâmetro } \\
\text { mínimo } \\
(\mathrm{mm})\end{array}$ & $\begin{array}{c}\text { Diâmetro } \\
\text { médio } \\
(\mathrm{mm})\end{array}$ \\
\hline 1 & 4,86 & 3,47 & 4,04 & 43 & 2,87 & 2,32 & 2,61 \\
\hline 2 & 4,41 & 3,06 & 3,91 & 44 & 3,92 & 2,87 & 3,37 \\
\hline 3 & 3,80 & 3,34 & 3,60 & 45 & 5,45 & 2,54 & 3,72 \\
\hline 4 & 3,21 & 2,43 & 2,85 & 46 & 4,14 & 3,04 & 3,57 \\
\hline 5 & 4,12 & 2,40 & 3,47 & 47 & 4,13 & 3,07 & 3,44 \\
\hline 6 & 4,03 & 2,59 & 3,22 & 48 & 5,10 & 3,40 & 4,15 \\
\hline 7 & 4,90 & 2,98 & 3,80 & 49 & 3,44 & 2,55 & 3,05 \\
\hline 8 & 4,26 & 2,17 & 3,13 & 50 & 5,34 & 2,17 & 3,77 \\
\hline 9 & 5,47 & 2,88 & 4,05 & 51 & 4,12 & 2,98 & 3,52 \\
\hline 10 & 3,70 & 3,04 & 3,33 & 52 & 3,06 & 2,12 & 2,67 \\
\hline 11 & 3,54 & 2,83 & 3,22 & 53 & 4,10 & 3,16 & 3,56 \\
\hline 12 & 5,44 & 3,06 & 4,07 & 54 & 4,17 & 3,06 & 3,67 \\
\hline 13 & 4,94 & 2,43 & 3,57 & 55 & 3,35 & 2,69 & 3,03 \\
\hline 14 & 3,92 & 3,00 & 3,49 & 56 & 3,52 & 2,97 & 3,28 \\
\hline 15 & 2,64 & 2,17 & 2,42 & 57 & 3,68 & 2,51 & 3,09 \\
\hline 16 & 4,03 & 2,84 & 3,20 & 58 & 3,75 & 2,46 & 3,23 \\
\hline 17 & 4,77 & 1,84 & 3,00 & 59 & 5,30 & 3,95 & 4,71 \\
\hline 18 & 5,04 & 3,37 & 4,20 & 60 & 4,01 & 3,06 & 3,54 \\
\hline 19 & 5,68 & 3,20 & 4,60 & 61 & 3,67 & 2,52 & 3,01 \\
\hline 20 & 3,98 & 2,24 & 3,08 & 62 & 4,68 & 2,17 & 3,21 \\
\hline 21 & 5,22 & 3,24 & 4,08 & 63 & 3,44 & 1,70 & 2,46 \\
\hline 22 & 3,81 & 2,01 & 3,09 & 64 & 4,35 & 2,95 & 3,73 \\
\hline 23 & 3,27 & 2,69 & 3,03 & 65 & 4,74 & 3,52 & 3,94 \\
\hline 24 & 4,49 & 2,54 & 3,66 & 66 & 5,00 & 3,18 & 3,90 \\
\hline 25 & 5,30 & 2,17 & 3,41 & 67 & 4,36 & 2,17 & 3,09 \\
\hline 26 & 4,06 & 2,09 & 3,11 & 68 & 4,87 & 2,13 & 3,33 \\
\hline 27 & 4,97 & 2,54 & 3,55 & 69 & 4,13 & 1,86 & 3,07 \\
\hline 28 & 4,12 & 2,98 & 3,46 & 70 & 4,07 & 3,00 & 3,61 \\
\hline 29 & 5,59 & 2,27 & 3,73 & 71 & 4,50 & 2,01 & 3,12 \\
\hline 30 & 4,53 & 1,67 & 3,06 & 72 & 3,29 & 1,77 & 2,61 \\
\hline 31 & 4,67 & 2,13 & 3,32 & 73 & 4,53 & 2,22 & 3,42 \\
\hline 32 & 4,25 & 2,95 & 3,42 & 74 & 4,01 & 2,98 & 3,59 \\
\hline 33 & 3,92 & 2,64 & 3,26 & 75 & 4,61 & 2,69 & 3,41 \\
\hline 34 & 3,85 & 2,12 & 2,71 & 76 & 4,58 & 2,22 & 3,48 \\
\hline 35 & 3,11 & 2,12 & 2,61 & 77 & 5,32 & 3,52 & 4,08 \\
\hline 36 & 5,17 & 2,27 & 3,48 & 78 & 4,77 & 2,60 & 3,59 \\
\hline 37 & 3,32 & 2,24 & 2,75 & 79 & 4,09 & 3,42 & 3,70 \\
\hline 38 & 4,64 & 3,42 & 4,05 & 80 & 4,01 & 2,39 & 3,33 \\
\hline 39 & 4,77 & 2,24 & 3,19 & 81 & 4,37 & 3,80 & 4,06 \\
\hline 40 & 3,37 & 2,27 & 2,85 & 82 & 4,63 & 1,94 & 3,40 \\
\hline 41 & 3,98 & 2,88 & 3,50 & 83 & 4,03 & 2,77 & 3,49 \\
\hline 42 & 4,14 & 2,83 & 3,40 & 84 & 4,25 & 3,06 & 3,62 \\
\hline
\end{tabular}


Para o lote de 84 partículas de basalto analisado, foram obtidas as seguintes médias com seus respectivos desvios:

$$
\begin{aligned}
& \overline{\mathrm{d}}_{\text {max }}=(4,27 \pm 0,68) \mathrm{mm} \\
& \overline{\mathrm{d}}_{\text {min }}=(2,66 \pm 0,51) \mathrm{mm} \\
& \overline{\mathrm{d}}_{\text {med }}=(3,42 \pm 0,45) \mathrm{mm}
\end{aligned}
$$

Os resultados obtidos para o basalto já indicaram médias mais distantes entre si e desvios maiores. Apesar da partícula ser muito mais irregular, a média dos diâmetros médios foi bem próxima ao valor encontrado para a alumina, entretanto foi um pouco divergente do diâmetro médio obtido no peneiramento do basalto $(3,08 \mathrm{~mm})$.

\section{CARVÃO ATIVADO}

As análises de imagem de partículas de carvão ativado foram realizadas para dois grupos: o grupo I com diâmetro médio de peneira de 2,16 mm e o grupo II com diâmetro médio de peneira de 3,08 mm. A Figura 5.7 mostra a imagem do grupo $\mathrm{I}$.

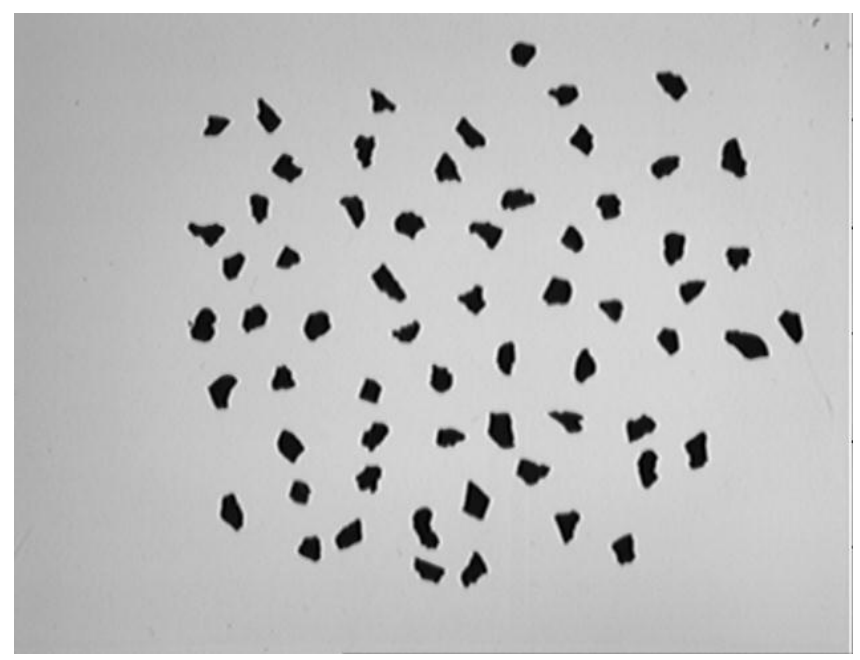

Figura 5.7 - Imagem registrada das partículas de carvão ativado (grupo I).

As Tabelas 5.5 e 5.6 mostram, respectivamente os resultados indicados pelo software Image Pro Plus para a análise dos diâmetros de cada partícula 
do grupo I (com 64 partículas) e do grupo II (com 64 partículas) de carvão ativado selecionado.

Tabela 5.5 - Análise do software Image Pro Plus para o diâmetro máximo, mínimo e médio de cada partícula do grupo I (carvão ativado).

\begin{tabular}{|c|c|c|c|c|c|c|c|}
\hline partícula & $\begin{array}{c}\text { diâmetro } \\
\text { máximo } \\
(\mathrm{mm})\end{array}$ & $\begin{array}{c}\text { diâmetro } \\
\text { mínimo } \\
(\mathrm{mm})\end{array}$ & $\begin{array}{c}\text { diâmetro } \\
\text { médio } \\
(\mathrm{mm})\end{array}$ & partícula & $\begin{array}{c}\text { diâmetro } \\
\text { máximo } \\
(\mathrm{mm})\end{array}$ & $\begin{array}{c}\text { diâmetro } \\
\text { mínimo } \\
(\mathrm{mm})\end{array}$ & $\begin{array}{c}\text { diâmetro } \\
\text { médio } \\
(\mathrm{mm})\end{array}$ \\
\hline 1 & 3,28 & 2,78 & 2,98 & 33 & 4,41 & 2,24 & 3,31 \\
\hline 2 & 4,32 & 2,40 & 3,41 & 34 & 3,92 & 2,91 & 3,36 \\
\hline 3 & 3,77 & 2,32 & 2,79 & 35 & 3,56 & 1,84 & 2,70 \\
\hline 4 & 3,47 & 1,84 & 2,59 & 36 & 0,10 & 0,25 & 0,17 \\
\hline 5 & 4,48 & 2,29 & 3,34 & 37 & 3,47 & 2,29 & 2,84 \\
\hline 6 & 3,29 & 2,17 & 2,68 & 38 & 6,31 & 2,68 & 4,22 \\
\hline 7 & 4,36 & 1,93 & 3,60 & 39 & 4,12 & 2,15 & 2,91 \\
\hline 8 & 3,82 & 2,54 & 3,01 & 40 & 4,20 & 2,43 & 3,14 \\
\hline 9 & 3,99 & 1,97 & 3,01 & 41 & 3,62 & 2,56 & 3,04 \\
\hline 10 & 5,04 & 2,35 & 3,68 & 42 & 3,22 & 2,43 & 2,87 \\
\hline 11 & 3,82 & 2,53 & 3,29 & 43 & 4,34 & 2,58 & 3,59 \\
\hline 12 & 3,47 & 2,60 & 3,11 & 44 & 3,04 & 2,33 & 2,71 \\
\hline 13 & 3,92 & 2,15 & 3,02 & 45 & 4,39 & 1,93 & 3,05 \\
\hline 14 & 4,20 & 2,15 & 3,09 & 46 & 5,15 & 2,91 & 3,87 \\
\hline 15 & 3,59 & 1,97 & 2,77 & 47 & 3,77 & 2,15 & 3,28 \\
\hline 16 & 3,41 & 2,49 & 2,99 & 48 & 3,93 & 2,04 & 3,23 \\
\hline 17 & 4,03 & 2,09 & 3,16 & 49 & 3,41 & 1,97 & 2,70 \\
\hline 18 & 3,82 & 2,80 & 3,28 & 50 & 4,20 & 2,72 & 3,40 \\
\hline 19 & 4,38 & 1,93 & 3,25 & 51 & 4,64 & 2,32 & 3,39 \\
\hline 20 & 4,29 & 1,93 & 3,51 & 52 & 4,67 & 2,04 & 3,49 \\
\hline 21 & 3,34 & 2,29 & 2,90 & 53 & 4,14 & 2,53 & 3,31 \\
\hline 22 & 4,14 & 2,43 & 3,24 & 54 & 3,68 & 2,33 & 3,11 \\
\hline 23 & 2,93 & 2,16 & 2,60 & 55 & 3,19 & 2,26 & 2,64 \\
\hline 24 & 3,07 & 2,16 & 2,75 & 56 & 5,25 & 2,95 & 3,66 \\
\hline 25 & 3,37 & 2,24 & 2,81 & 57 & 4,76 & 2,60 & 3,53 \\
\hline 26 & 5,22 & 2,24 & 3,83 & 58 & 5,44 & 1,79 & 3,87 \\
\hline 27 & 3,83 & 3,05 & 3,44 & 59 & 3,58 & 2,33 & 2,96 \\
\hline 28 & 3,43 & 2,04 & 2,85 & 60 & 4,57 & 2,32 & 3,33 \\
\hline 29 & 3,34 & 2,49 & 2,92 & 61 & 3,68 & 2,49 & 3,07 \\
\hline 30 & 2,91 & 2,24 & 2,60 & 62 & 3,28 & 2,56 & 2,92 \\
\hline 31 & 3,77 & 2,48 & 3,07 & 63 & 4,52 & 2,02 & 3,37 \\
\hline 32 & 4,41 & 2,60 & 3,69 & 64 & 4,30 & 2,24 & 3,19 \\
\hline
\end{tabular}

Para o grupo I foram obtidas as seguintes médias com seus respectivos desvios:

$$
\begin{aligned}
& \overline{\mathrm{d}}_{\text {max }}=(3,93 \pm 0,82) \mathrm{mm} \\
& \overline{\mathrm{d}}_{\text {min }}=(2,29 \pm 0,39) \mathrm{mm} \\
& \overline{\mathrm{d}}_{\text {med }}=(3,12 \pm 0,52) \mathrm{mm}
\end{aligned}
$$


Tabela 5.6 - Análise do software Image Pro Plus para o diâmetro máximo, mínimo e médio de cada partícula do grupo II (carvão ativado).

\begin{tabular}{|c|c|c|c|c|c|c|c|}
\hline partícula & $\begin{array}{c}\text { diâmetro } \\
\text { máximo } \\
(\mathrm{mm})\end{array}$ & $\begin{array}{c}\text { diâmetro } \\
\text { mínimo } \\
(\mathrm{mm})\end{array}$ & $\begin{array}{l}\text { diâmetro } \\
\text { médio } \\
\text { (mm) }\end{array}$ & partícula & $\begin{array}{c}\text { diâmetro } \\
\text { máximo } \\
(\mathrm{mm})\end{array}$ & $\begin{array}{c}\text { diâmetro } \\
\text { mínimo } \\
(\mathrm{mm})\end{array}$ & $\begin{array}{c}\text { diâmetrc } \\
\text { médio } \\
(\mathrm{mm})\end{array}$ \\
\hline 1 & 3,82 & 3,12 & 3,48 & 33 & 4,69 & 3,22 & 3,97 \\
\hline 2 & 4,91 & 3,18 & 4,31 & 34 & 5,01 & 3,16 & 3,92 \\
\hline 3 & 4,42 & 3,08 & 3,58 & 35 & 5,05 & 2,48 & 3,63 \\
\hline 4 & 6,06 & 3,22 & 4,49 & 36 & 6,44 & 2,88 & 4,73 \\
\hline 5 & 3,41 & 2,58 & 2,96 & 37 & 4,85 & 3,22 & 4,04 \\
\hline 6 & 4,64 & 3,06 & 3,67 & 38 & 4,85 & 2,43 & 3,54 \\
\hline 7 & 6,50 & 2,88 & 4,52 & 39 & 4,29 & 3,22 & 3,71 \\
\hline 8 & 4,30 & 3,22 & 3,68 & 40 & 4,82 & 3,47 & 4,06 \\
\hline 9 & 4,41 & 2,33 & 3,35 & 41 & 3,83 & 2,72 & 3,27 \\
\hline 10 & 3,82 & 2,93 & 3,29 & 42 & 4,85 & 3,28 & 4,01 \\
\hline 11 & 4,23 & 2,73 & 3,34 & 43 & 5,58 & 3,22 & 4,20 \\
\hline 12 & 5,21 & 3,45 & 4,25 & 44 & 4,11 & 3,04 & 3,46 \\
\hline 13 & 5,25 & 3,73 & 4,41 & 45 & 4,69 & 3,12 & 3,88 \\
\hline 14 & 5,23 & 2,49 & 3,62 & 46 & 5,08 & 2,93 & 3,74 \\
\hline 15 & 4,32 & 3,04 & 3,64 & 47 & 4,63 & 2,78 & 3,60 \\
\hline 16 & 3,62 & 2,43 & 2,93 & 48 & 4,55 & 3,19 & 4,07 \\
\hline 17 & 4,75 & 1,77 & 3,47 & 49 & 4,26 & 3,19 & 3,77 \\
\hline 18 & 4,34 & 2,70 & 3,47 & 50 & 4,55 & 2,15 & 3,22 \\
\hline 19 & 4,24 & 2,93 & 3,68 & 51 & 4,17 & 3,19 & 3,53 \\
\hline 20 & 5,82 & 3,41 & 4,31 & 52 & 4,58 & 3,68 & 4,01 \\
\hline 21 & 6,24 & 3,04 & 4,64 & 53 & 7,12 & 2,17 & 4,33 \\
\hline 22 & 4,17 & 3,19 & 3,65 & 54 & 4,04 & 2,99 & 3,35 \\
\hline 23 & 4,36 & 2,88 & 3,72 & 55 & 4,81 & 2,60 & 3,61 \\
\hline 24 & 3,99 & 3,39 & 3,70 & 56 & 5,11 & 3,22 & 4,39 \\
\hline 25 & 4,55 & 3,04 & 3,64 & 57 & 4,52 & 3,28 & 3,89 \\
\hline 26 & 4,64 & 2,18 & 3,75 & 58 & 5,91 & 1,97 & 3,88 \\
\hline 27 & 5,60 & 3,22 & 4,26 & 59 & 5,77 & 2,72 & 4,39 \\
\hline 28 & 5,58 & 3,72 & 4,66 & 60 & 4,32 & 2,29 & 3,36 \\
\hline 29 & 4,55 & 3,47 & 4,03 & 61 & 3,64 & 2,32 & 3,13 \\
\hline 30 & 4,50 & 2,68 & 3,55 & 62 & 6,41 & 2,88 & 4,60 \\
\hline 31 & 4,76 & 2,73 & 3,90 & 63 & 3,93 & 2,72 & 3,31 \\
\hline 32 & 6,22 & 3,04 & 4,55 & 64 & 5,76 & 2,16 & 3,67 \\
\hline
\end{tabular}

Para o grupo II foram obtidas as seguintes médias com seus respectivos desvios:

$$
\begin{aligned}
& \overline{\mathrm{d}}_{\max }=(4,82 \pm 0,79) \mathrm{mm} \\
& \overline{\mathrm{d}}_{\text {min }}=(2,92 \pm 0,43) \mathrm{mm} \\
& \overline{\mathrm{d}}_{\text {med }}=(3,82 \pm 0,44) \mathrm{mm}
\end{aligned}
$$

Da mesma forma que para o basalto, as médias encontradas indicam uma grande irregularidade das partículas. Para o carvão, a média dos 
diâmetros médios, calculada pelo software, foi bem diferente do diâmetro médio obtido através de peneiramento.

Analisando exclusivamente sob o aspecto da homogeneidade dos diâmetros, os resultados das análises de imagens mostram que, em situações e experimentos que exigem partículas com tamanhos semelhantes, obviamente a alumina leva grande vantagem em relação às demais, justamente por essa partícula ser obtida através de um processo controlado de produção. 0 diâmetro médio resultante do software foi bem próximo do fornecido pelo fabricante. Já para o basalto e o carvão ativado, o diâmetro médio apresentado pelo software foi bem maior do que o diâmetro médio obtido pelo peneiramento.

As análises que exigem similaridade entre as partículas podem ficar extremamente prejudicadas com a utilização das partículas irregulares, pois é praticamente impossível obter homogeneidade nas amostras. Mesmo técnicas simples e consagradas de separação, como o peneiramento, não são tão eficazes para cumprir esse requisito. No peneiramento, muitas vezes uma das dimensões da partícula concorda com a abertura da malha, e a partícula acaba sendo selecionada. Porém, como foi mostrado na análise de imagens, as dimensões das outras faces podem ser de inúmeros tamanhos e proporcionar as mais variadas formas entre as partículas: alongadas, retangulares, triangulares, dentre outras.

A análise de imagens, no entanto, não é uma técnica de separação de partículas, mas sim um mecanismo que fornece várias informações para um lote selecionado. Por se tratar de uma técnica usual de separação, o peneiramento foi escolhido para ser utilizado em toda a pesquisa, quando a separação foi necessária. Como já foi observado, é preciso enfatizar que as diferenças de diâmetros estão relacionadas com a grande irregularidade das partículas, e não com a precisão do método de separação.

\subsubsection{FLUIDODINÂMICA NO REATOR A COM PARTÍCULAS INERTES}

A Tabela 5.7 mostra a faixa de diâmetros selecionados para os ensaios de fluidodinâmica no reator $A$. 
Tabela 5.7 - Partículas utilizadas nos ensaios de fluidodinâmica no reator A, seus diâmetros e metodologia de seleção desses diâmetros.

\begin{tabular}{ccc}
\hline PARTÍCULA & DIÂMETRO $(\mathbf{m m})$ & METODOLOGIA \\
\hline ALUMINA & 3,5 & Fabricante \\
BASALTO & De 2 a 3,36 & Peneiramento $^{*}$ \\
CARVÃO ATIVADO & De 2 a 3,36 & Peneiramento $^{*}$ \\
Obs.: ${ }^{*}$ ) diâmetro que passou na peneira \#3,36 e ficou retido na peneira \#2
\end{tabular}

Para as partículas de alumina não houve emprego de metodologias para a separação de partículas por tamanho. Elas foram colocadas no leito através de lançamento manual, do topo para baixo.Para o basalto e o carvão houve um peneiramento, para eliminar as partículas maiores que 3,36 $\mathrm{mm}$ e menores que $2 \mathrm{~mm}$. No momento de seus respectivos ensaios, o basalto e o carvão foram colocados no reator da mesma maneira que a alumina. Antes de ser colocado, porém, o carvão passou pelos processos de eliminação descritos na metodologia. Assim, foram eliminadas as partículas flutuantes e depois, já dentro do reator, foram eliminadas através de elutriação as partículas mais instáveis (de topo). A alumina e o basalto foram colocados numa quantidade que resultou em uma altura do leito (em repouso) de $30 \mathrm{~cm}$, e o carvão $40 \mathrm{~cm}$.

Os valores de diferença de pressão em função da velocidade superficial foram obtidos para o reator sem partículas, e são apresentados na Figura 5.8.

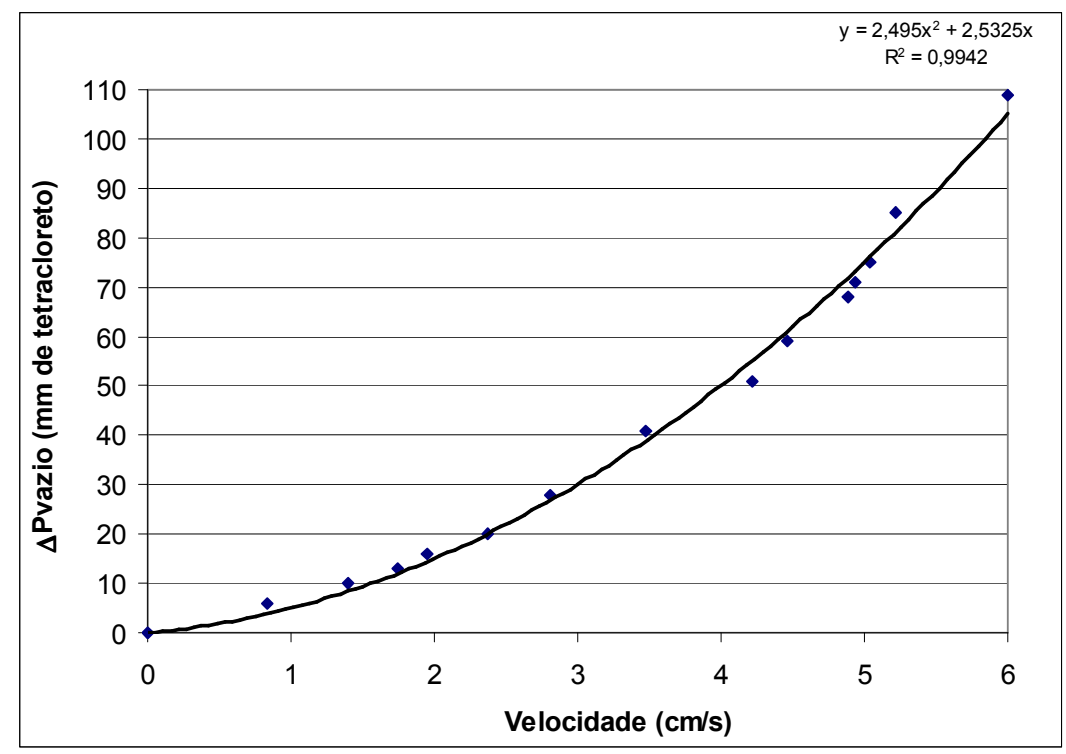

Figura 5.8 - Diferenças de pressão em função da velocidade para o reator A, sem partículas. 
Aos pontos obtidos para o reator vazio foi ajustada uma equação do segundo grau, obtendo-se uma relação entre diferença de pressão e velocidade com alto coeficiente de correlação $(0,9942)$. Assim foi possível determinar a diferença de pressão para qualquer velocidade na faixa de velocidade utilizada nos experimentos.

Quanto à fluidodinâmica do reator com partículas inertes, todos os ensaios foram feitos em triplicata. Já que uma boa reprodutibilidade foi obtida, e para facilitar a comparação, a Figura 5.9 mostra a curva característica conjunta, ou seja, os resultados obtidos para os 3 ensaios de cada material suporte. É possível observar facilmente o comportamento diferenciado do leito para cada material.

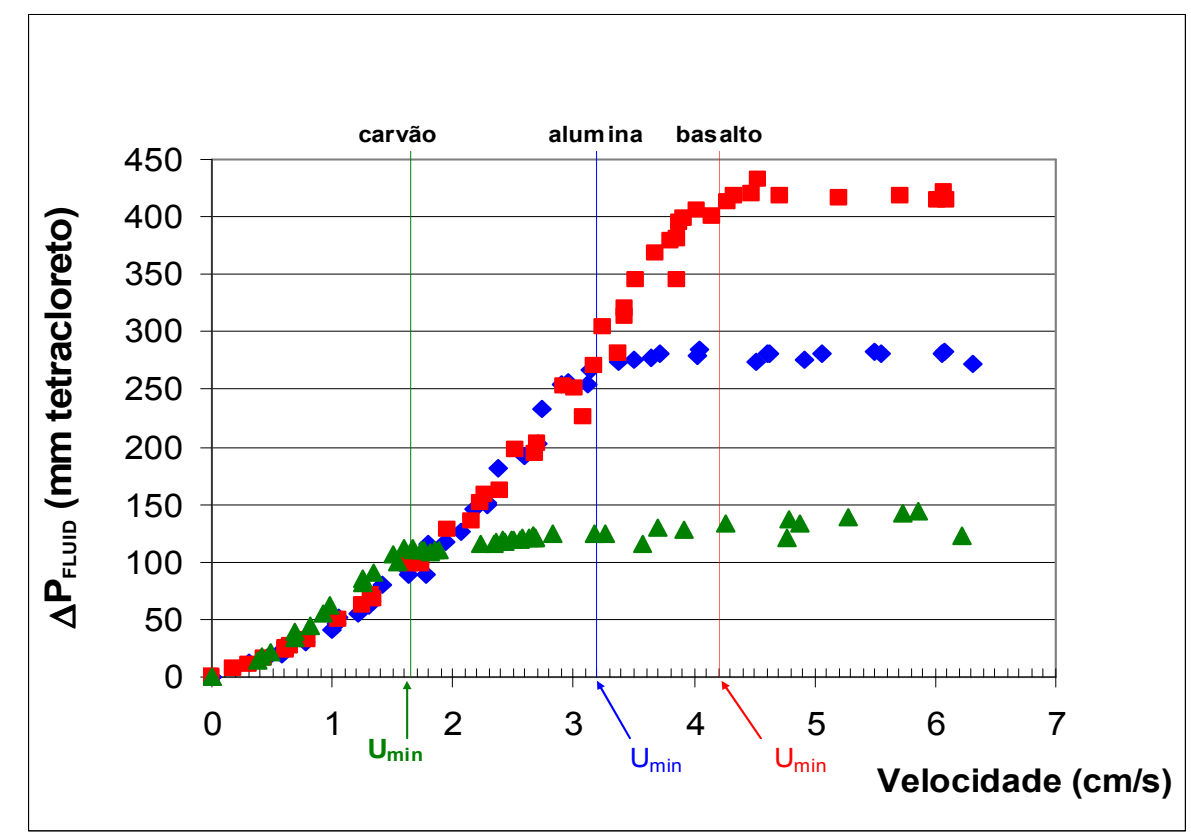

Figura 5.9 - Curva característica para o reator A preenchido com três diferentes materiais suportes, com indicação das velocidades de mínima fluidificação. (•) alumina ( $\square$ ) basalto ( $\Delta$ ) carvão.

O gráfico de $\Delta P_{\text {FLUID }}$ em função da velocidade superficial mostra claramente, para cada material suporte, as duas regiões que descrevem o comportamento de leitos bifásicos, e que fornecem informações muito importantes para o estabelecimento de critérios de projeto, pois o ponto de intersecção entre elas $\left(U_{\min }\right)$ define a mudança do regime de escoamento, ou seja, de leito fixo para leito fluidificado. Para facilitar a discussão dos 
resultados, a região anterior a $U_{\min }$ será denominada de região $A$, e a região posterior à $U_{\min }$ será denominada região $B$.

$\mathrm{Na}$ análise da figura verifica-se que, diferente da observação de Briens et al. (1997a), a região A não é "claramente" linear. A região A é uma região importante de análise, pois está diretamente relacionada com a permeabilidade do leito fixo e sua declividade dependerá da resistência que o conjunto de partículas proporcionará ao escoamento do fluido. Portanto, dentre outros fatores, a permeabilidade dependerá do tipo, densidade, forma geométrica, tamanho da partícula e da relação entre o diâmetro da partícula e o diâmetro do leito que as contém.

Observou-se visualmente durante a experimentação que nessa faixa de velocidades ascensionais as partículas permanecem em constante reorientação. Essa reorientação das partículas é um fenômeno individual, e embora não provoque no leito qualquer movimento de expansão, é capaz de alterar suas condições de permeabilidade. Essa região seria uma reta apenas se a permeabilidade do leito permanecesse constante. Porém, aproximando-se a região $\mathrm{A}$ a uma reta, obtém-se uma boa estimativa para a permeabilidade média do leito. Ajustando os pontos obtidos na região $A$ a uma parábola é possível determinar, através da derivada da equação obtida, a permeabilidade do leito para cada velocidade ascensional. Para este trabalho esses parâmetros não foram calculados em virtude da região de interesse ser a do leito fluidificado.

Os valores encontrados para as velocidades de mínima fluidificação do leito com carvão ativado, alumina e basalto foram, respectivamente, 1,7; 3,2; e $4,2 \mathrm{~cm} / \mathrm{s}$. Em metros por hora esses valores correspondem respectivamente a 61,2; 115,2; e 151,2. Lembrando que a Figura 5.9 contém as 3 curvas características de cada material (totalizando 9 ensaios), pode-se perceber que uma ótima reprodutibilidade foi conseguida para os três materiais. Para as partículas de alumina essa reprodutibilidade já era de certo modo esperada, principalmente devido ao seu formato esférico regular. O carvão ativado, mesmo com toda a irregularidade e instabilidade das partículas, também apresentou uma ótima curva característica, mostrando que a metodologia utilizada para garantir uma fluidificação mais qualificada, ou seja, a expulsão das partículas menos densas antes dos ensaios, foi apropriada para garantir 
uma melhor análise fluidodinâmica para esta partícula, comprovada também nos ensaios de expansão do leito, que serão mostrados posteriormente. Não houve dificuldade em identificar graficamente os pontos de intersecção que determinaram $U_{\min }$ para cada material.

A região $B$, para as três partículas analisadas, confirma uma das mais respeitadas definições sobre fluidificação, que diz que a mistura assume propriedades macroscópicas de um fluido homogêneo. Nesse caso, a diferença de pressão hidrostática no leito pode ser diretamente determinada através da densidade média da mistura multiplicada pela aceleração da gravidade (g). Em outras palavras, isto quer dizer que a partir de $U_{\min } \mathrm{O}$ valor de diferença de pressão praticamente não se altera. Partículas mais densas proporcionarão maiores pressões no leito, como foi o caso do basalto e da alumina em relação ao carvão.

As Figuras 5.10 e 5.11 mostram, respectivamente, os resultados obtidos para a expansão do leito e a porosidade.

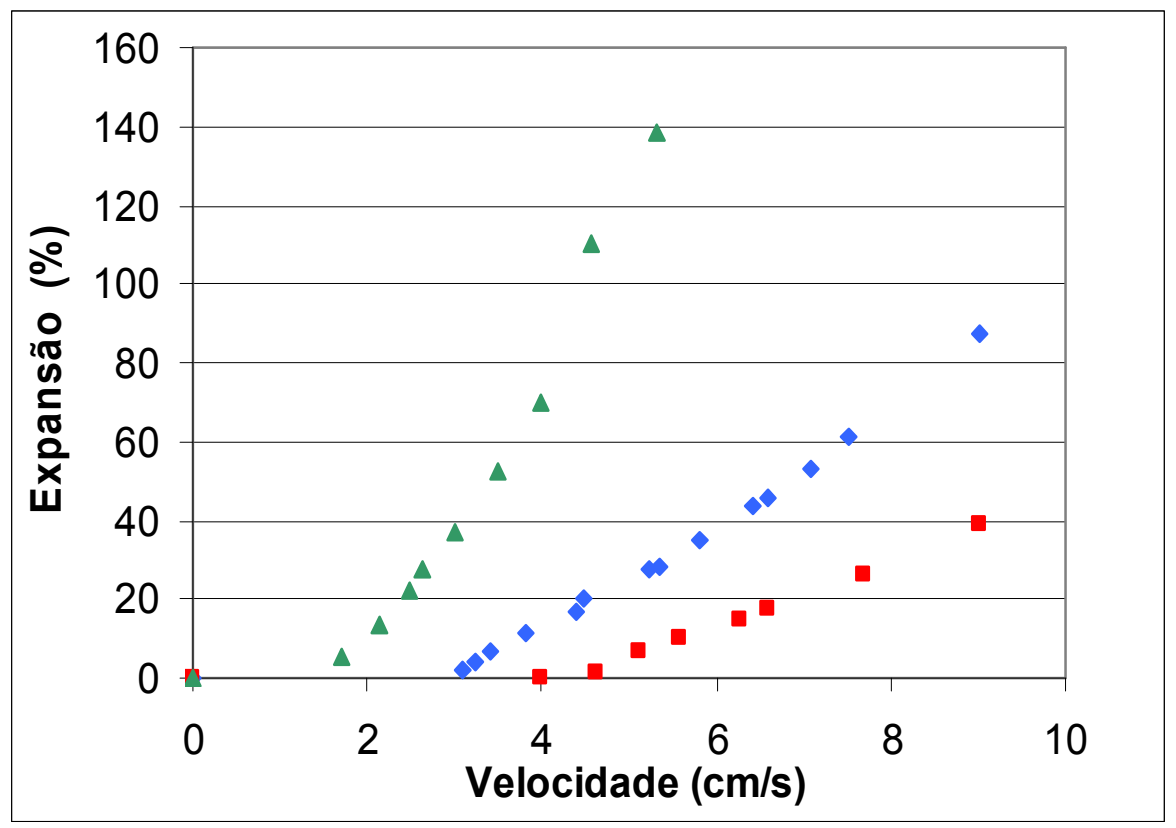

Figura 5.10 - Expansão do leito do reator A preenchido com três diferentes materiais suporte. $(\bullet)$ alumina $(\square)$ basalto $(\Delta)$ carvão.

Os resultados mostram que o leito, quando preenchido com carvão ativado, apresentou a maior derivada (dz/dU), e portanto alcançou rapidamente 
uma grande expansão, para velocidades mais baixas que para os outros dois materiais. Essa expansão foi limitada pela própria altura do reator.

No basalto, por exemplo, uma vazão próxima da máxima possível (do conjunto de bombas em paralelo), foi suficiente para uma expansão de apenas $40 \%$. Além disso, as pressões no leito foram muito maiores, chegando quase a quatro vezes o valor das pressões para o leito com carvão ativado

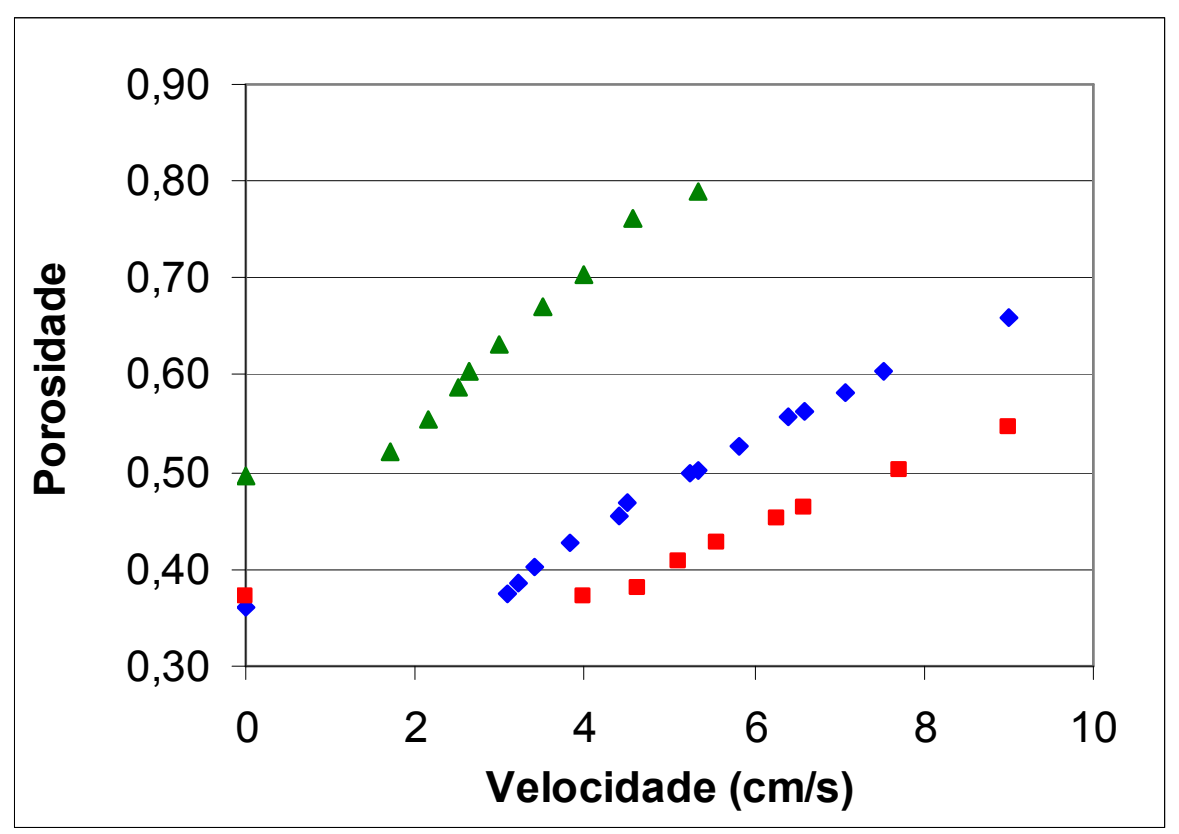

Figura 5.11 - Porosidade do leito do reator A preenchido com três diferentes materiais suporte. $(\bullet)$ alumina $(\square)$ basalto $(\Delta)$ carvão.

Com elevadas velocidades ascensionais necessárias para fluidificar e expandir o leito, o basalto apresentou fortes indícios de que seria uma opção inadequada para ser utilizado como suporte biológico, mesmo antes do ensaio de imobilização de biomassa. Além do grande gasto de energia no bombeamento, as elevadas velocidades certamente provocariam um cisalhamento excessivo no biofilme formado. Mesmo assim, cumprindo a programação inicial, o ensaio de imobilização foi realizado também com essa partícula. 


\subsubsection{POTENCIAL DE IMOBILIZAÇÃO DE BIOMASSA}

Para facilitar a comparação, a Figura 5.12 mostra os resultados obtidos para os três suportes nos 28 dias de ensaio. Nesse gráfico, os resultados são apresentados na forma de massa de microrganismos (miligramas de sólidos totais voláteis) por massa total de suporte colocada dentro do reator (gramas de suporte).

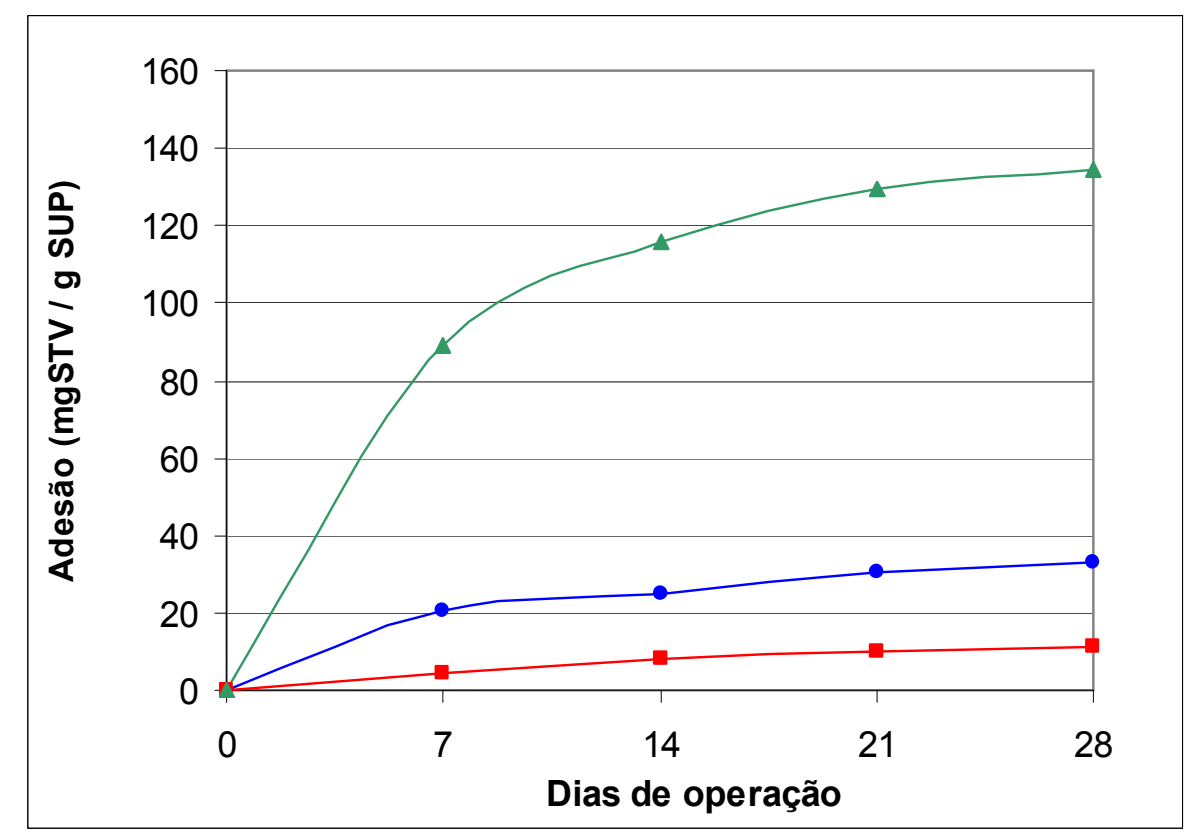

Figura 5.12 - Resultado (em mgSTV / gSUP) do ensaio de imobilização de biomassa em reatores "elemento de volume" para três diferentes materiais suporte. $(\bullet)$ alumina ( $($ ) basalto $(\Delta)$ carvão.

Apesar da proximidade dos diâmetros, os três materiais possuíam densidades bem diferentes. Por ser menos denso que os outros, a massa de carvão ativado colocada no reator "elemento de volume", por exemplo, foi de aproximadamente 7 gramas, enquanto para o basalto 0 valor foi de aproximadamente 20 gramas. Ou seja, exprimir os resultados em massa de sólidos aderidos por massa de suporte poderia não ser a melhor forma de comparar a aderência de biomassa. Seria mais apropriado utilizar no denominador um parâmetro igual para todos os suportes. Dessa maneira, verificou-se que uma forma mais eficiente de apresentar e comparar os resultados seria expressá-los na forma de massa de sólidos aderidos (STV) por 
volume de reator. O reator "elemento de volume" utilizado nos ensaios dos três materiais possuía um volume de aproximadamente $15,9 \mathrm{~mL}$. Assim, a Figura 5.13 apresenta os resultados nesse formato, para os três materiais avaliados, ou seja, a alumina, o basalto e o carvão ativado.

Analisando as Figuras 5.12 e 5.13, percebe-se que para os dois critérios de apresentação dos resultados, o carvão ativado mostrou adesão de microrganismos bem superior aos outros dois materiais, e o comportamento entre a alumina e o basalto foi bem próximo, com a alumina levando pequena vantagem.

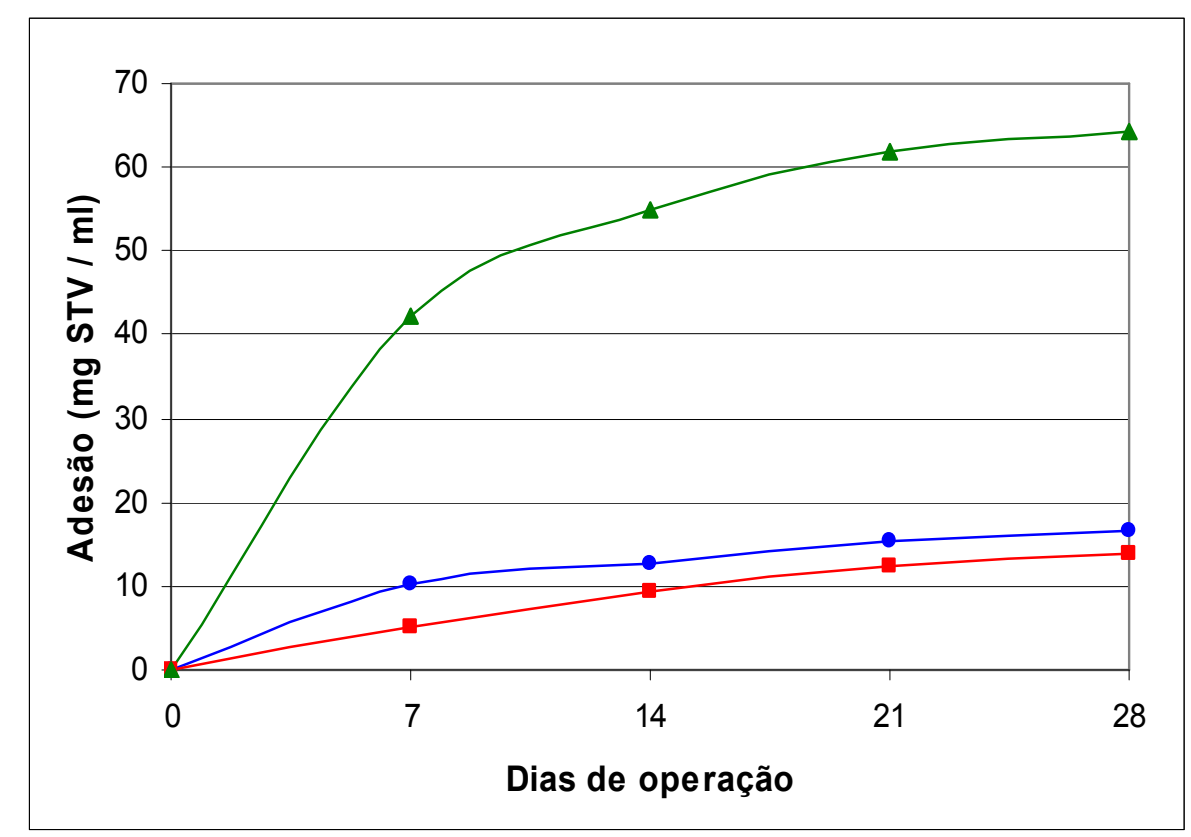

Figura 5.13 - Resultado (em mgSTV / mLSUP) do ensaio de imobilização de biomassa em reatores "elemento de volume" para três diferentes materiais suporte. $(\bullet)$ alumina $(\square)$ basalto $(\Delta)$ carvão.

Talvez a explicação mais simples e imediata, porém não menos verdadeira, esteja no fato de serem três materiais totalmente diferentes, cada um com sua composição química, estrutura, parâmetros físicos, dentre outros. Essa explicação, aliada aos vários fenômenos de formação do biofilme, já explicaria em grande parte as diferenças de comportamento encontradas na imobilização de biomassa. Entretanto, pode-se aprofundar essa análise através de outras informações. 


\subsubsection{DISCUSSÃO E ESCOLHA}

Analisando os parâmetros físicos obtidos com a caracterização dos materiais, a alumina e o carvão, dos três materiais suportes escolhidos, possuem porosidade interna maiores que $20 \%$. Já no basalto, esse valor é insignificante, não chegando aos $3 \%$. Além disso, no que diz respeito à área total de poros, o valor obtido para o basalto, $1,74 \mathrm{~m}^{3} / \mathrm{g}$, também ficou consideravelmente abaixo do encontrado para a alumina $\left(43,69 \mathrm{~m}^{3} / \mathrm{g}\right)$ e para o carvão ativado $\left(19,32 \mathrm{~m}^{3} / \mathrm{g}\right)$. Isso pode explicar, juntamente com a MEV do basalto, a baixa adesão de microrganismos nesse material, onde os fenômenos de formação de biofilme não tiveram área suficiente para sua ocorrência, ficando então um processo praticamente restrito à superfície da partícula.

Era de se esperar que a alumina, em virtude de seus elevados resultados de porosidade, área total de poros, e área específica, obtivesse uma adesão de biomassa superior, ou pelo menos próxima à do carvão. Os valores experimentais, entretanto, mostraram o contrário. Apesar das porosidades serem similares, e da área total de poros e área específica da alumina serem muito maiores que as do carvão, observou-se na Figura 5.12 que a sua adesão foi cerca de 4 vezes menor em comparação a esse material. Isso pode ser explicado pela análise dos valores de diâmetro médio dos poros.

Embora as partículas de alumina do lote utilizado na pesquisa possuam uma área de poros muito maior que o carvão, o diâmetro médio desses poros $(0,02 \mu \mathrm{m})$ é muito pequeno se comparado ao diâmetro médio dos poros do carvão ativado $(0,09 \mu \mathrm{m})$, e pode ter sido um dos fatores que dificultaram os processos de transferência de massa, para a formação do biofilme. Além disso, os "acidentes" e irregularidades, como as reentrâncias do carvão, mostradas na MEV, se por um lado foram prejudiciais na homogeneidade da partícula, podem ter sido importantes para criar condições favoráveis para a formação e imobilização de biomassa.

É importante acrescentar que outras características das partículas também podem influenciar substancialmente o processo de imobilização de biomassa e explicar as diferenças de desempenho entre os materiais suportes, tais como potencial hidrofóbico, hidrolítico, capacidade de adsorção, permeabilidade, geometria, dentre outros. As análises de microscopia da 
biomassa também fornecem boas informações qualitativas sobre o processo de imobilização. Análises de biomassa imobilizada em partículas de carvão (MENDONÇA, 1999) e de alumina (ORTEGA et al., 2001) já foram feitas e mostraram um potencial de imobilização de uma grande diversidade de organismos.

Obviamente que para viabilizar o trabalho, tendo em vista todas as outras investigações propostas, procurou-se escolher alguns dos critérios mais relevantes para essa avaliação, já que, como foi mostrado, muitos aspectos podem influenciar na avaliação de materiais para meio suporte. Acredita-se que os critérios escolhidos foram em quantidade suficiente para uma análise correta e representativa, e que sempre mostraram uma similaridade na ordem de desempenho.

$\mathrm{O}$ basalto apresentou, em todas as verificações, resultados inferiores aos outros materiais, o que não o credenciou como um bom meio suporte para pesquisas em processos biológicos de tratamento de águas residuárias.

A alumina é obtida artificialmente a partir da bauxita. Da mina, a bauxita é enviada à refinaria, onde se isola o óxido de alumínio por meio da retirada dos outros componentes (óxidos de ferro e de silício). Na refinaria, o minério é misturado com uma solução de soda cáustica, formando o aluminato de sódio. Depois que o óxido de ferro e outras impurezas são precipitadas, acrescentam cristais de alumínio hidratado. Formam-se cristais pesados que são posteriormente triturados para expelir a água remanescente, deixando um pó branco fino (chamado alumina), que é encaminhado para a redução. De 4 a 6 toneladas de minério de bauxita são produzidas 2 toneladas de alumina.

Esse material tem um ótimo potencial para se tornar um meio suporte de reatores biológicos. O grande problema do lote analisado foi uma elevada velocidade de mínima fluidificação, em comparação ao carvão, e também uma adesão de biomassa relativamente baixa, provavelmente devido ao reduzido diâmetro de poros. Sua durabilidade e forma geométrica bem definida são grandes atrativos. Com essas vantagens, aliadas à fabricação de partículas um pouco mais leves e com poros maiores (se possível), sua utilização poderá trazer resultados tão bons quanto os obtidos com carvão ativado.

O carvão ativado ainda é um dos melhores materiais para serem utilizados em processos biológicos, principalmente em reatores de leito 
fluidificado, porque o emprego deste material consegue aliar tanto bons resultados físicos, como biológicos. Sua capacidade de adesão de biomassa foi 4 vezes maior que a da partícula de alumina e pode não ter sido mera coincidência o diâmetro dos poros do carvão também ser 4 vezes maior que o da alumina. Sendo assim, através da avaliação dos materiais suportes, englobando ensaios de microscopia, de caracterização física, de fluidodinâmica e de imobilização de biomassa, o carvão ativado foi escolhido para a continuidade do trabalho, justamente por ter apresentado os melhores resultados. Apesar da desvantagem no aspecto geométrico, esse material se mostrou altamente eficiente. No que diz respeito ao caráter dinâmico, teve os melhores resultados entre os três materiais, uma vez que apresentou os menores valores para velocidade mínima de fluidificação e pressões. Isso significa, dentre outras vantagens, economia de energia, menor possibilidade de arraste de biomassa e maior tempo de vida útil dos equipamentos, que ficarão submetidos a menores pressões.

\subsection{ESTUDO DAS INTERAÇÕES}

Após a escolha do carvão ativado como melhor material suporte, uma série de análises foi realizada para estudar as diversas interações que fazem parte do sistema: partículas inertes e fluido; biopartículas e fluido; partícula inerte e fluido; biopartícula e fluido; partículas inertes e biomassa.

\subsubsection{INTERAÇÕES ENTRE AS PARTÍCULAS INERTES E O FLUIDO}

As interações entre as partículas inertes e o fluido foram analisadas através de ensaios fluidodinâmicos no reator $B$ e de isotermas de adsorção.

\subsubsection{FLUIDODINÂMICA DO REATOR B COM PARTÍCULAS INERTES}

Para os ensaios de fluidodinâmica no reator $B$, o carvão ativado foi peneirado em faixas granulométricas mais estreitas e dividido em dois grupos de tamanhos de partícula, conforme mostrado na Tabela 5.8. 
Tabela 5.8 - Partículas de carvão utilizadas nos ensaios de fluidodinâmica no reator $B$, seus diâmetros e metodologia de seleção desses diâmetros.

\begin{tabular}{ccl}
\hline PARTÍCULA & DIÂMETRO $(\mathbf{m m})$ & METODOLOGIA \\
\hline GRUPO 1 & 2,16 & Peneiramento $^{*}$ \\
GRUPO 2 & 3,08 & Peneiramento $^{*}$ \\
\hline
\end{tabular}

Obs.: $\left(^{*}\right)$ diâmetro médio de peneira

Apesar de o grupo II, em relação ao grupo I, ter um aumento no diâmetro médio de peneira de cerca de $42 \%$, corria-se o risco de não se obter uma diferença "mensurável" de comportamento, pois, como já foi relatado anteriormente, nenhuma técnica de separação poderia garantir uma divisão de partículas irregulares muito eficiente, fazendo com que, muito provavelmente, uma boa parcela de partículas de um grupo também pudesse ser encontrada no outro, e vice-versa. Entretanto, a expectativa foi de que a partir do momento em que o leito fosse analisado como um "todo", seria possível identificar diferenças de comportamento.

Os valores de diferença de pressão em função da velocidade superficial foram obtidos para o reator sem partículas, e são apresentados na Figura 5.14.

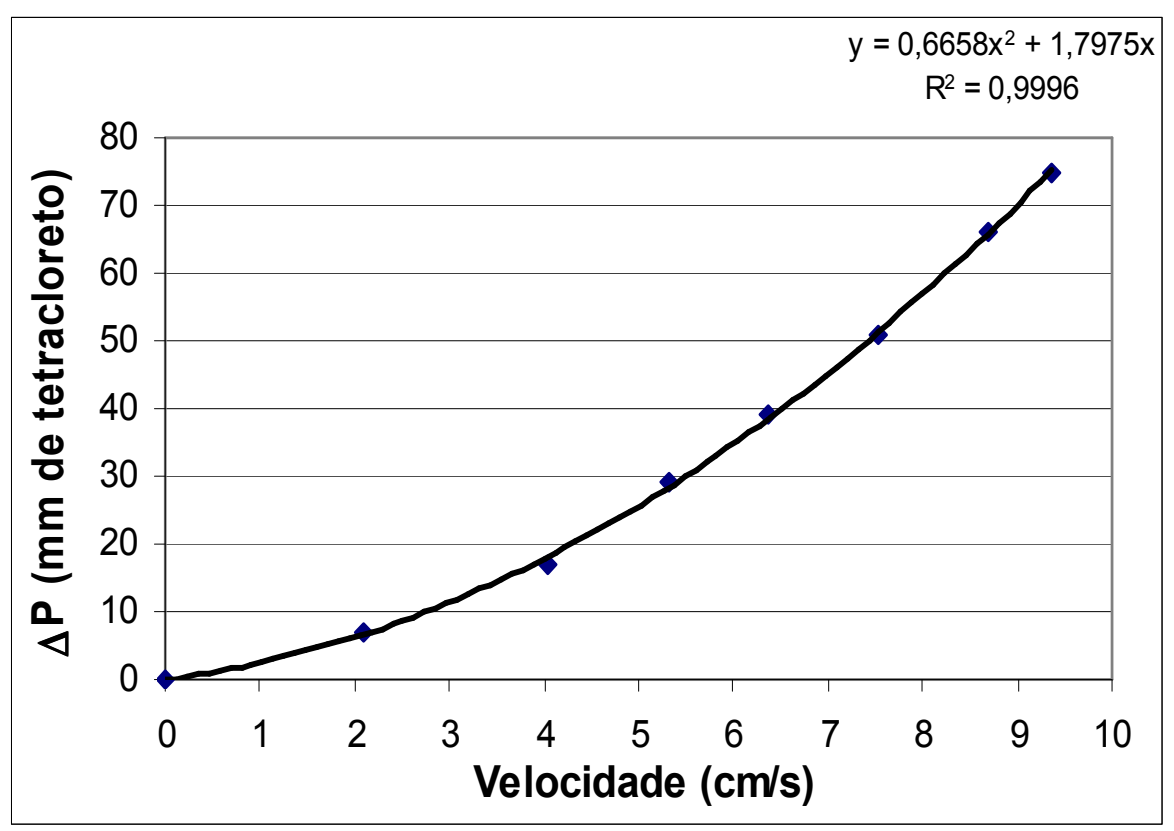

Figura 5.14 - Diferenças de pressão em função da velocidade para o reator B sem partículas. 
A Figura 5.15 mostra em um mesmo gráfico as curvas características obtidas para os dois grupos de partículas inertes. A região $A$ também apresentou comportamento de parábola, da mesma maneira que para o reator A, e apesar do comportamento bem similar, é possível identificar para os dois grupos suas respectivas velocidades de mínima fluidificação. Da mesma maneira que para o reator $A$, no reator $B$ foi possível identificar sem problemas a região de intersecção que define a mudança de comportamento do leito.

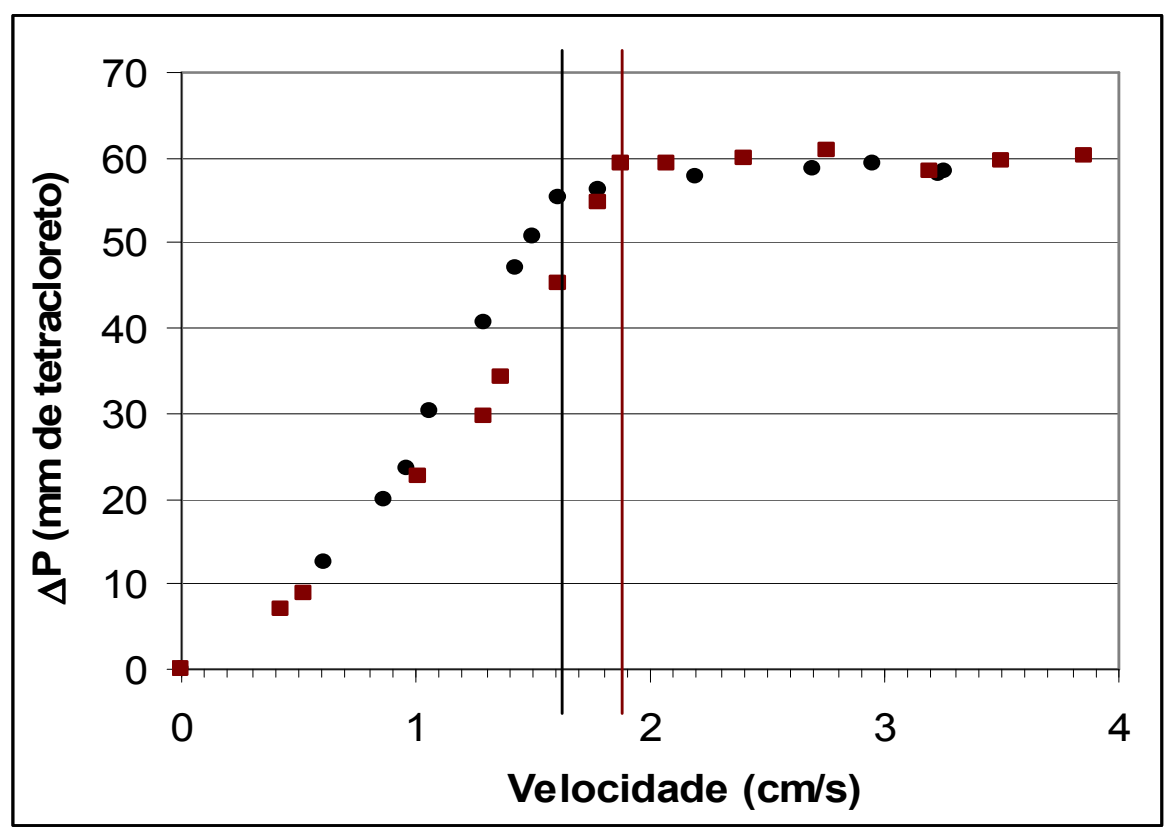

Figura 5.15 - Curva característica para o reator B preenchido com dois grupos de partículas inertes de carvão ativado, com indicação da velocidade de mínima fluidificação.

(• ) grupo I: partículas com diâmetro médio de 2,16 mm

(a ) grupo II: partículas com diâmetro médio de $3,08 \mathrm{~mm}$

As velocidades de mínima fluidificação obtidas para as partículas inertes com diâmetros de 2,16 e 3,08 mm foram, respectivamente, $1,6 \mathrm{~cm} / \mathrm{s}$ e 1,9 cm/s. Como esperado, a velocidade de mínima fluidificação para a partícula de 2,16 $\mathrm{mm}$ foi menor do que para as outras configurações de leito. Um aumento de cerca de $42 \%$ no diâmetro médio das partículas inertes, ou seja, de 2,16 mm para $3,08 \mathrm{~mm}$, resultou em um valor de $\cup_{\min } 19 \%$ maior. 
É interessante lembrar que o valor de $U_{\min }$ para o reator $A$ preenchido com partículas de carvão ativado foi de $1,7 \mathrm{~cm} / \mathrm{s}$. Esse valor ficou justamente entre o intervalo obtido para os dois grupos de partículas utilizados no reator $B$ $(1,6 \mathrm{~cm} / \mathrm{s}$ e $1,9 \mathrm{~cm} / \mathrm{s})$. Essa observação não é mera coincidência, e se deve principalmente ao fato de a distribuição granulométrica (de $2 \mathrm{~mm}$ a $3,36 \mathrm{~mm}$ ) selecionada para aquele ensaio ter sido mais abrangente do que a utilizada no reator $\mathrm{B}$.

As Figuras 5.16 e 5.17 mostram, respectivamente, os resultados obtidos para a expansão do leito e a porosidade. Como pode ser observado, o leito teve comportamento muito semelhante para os dois diâmetros de partícula inerte utilizados, principalmente perto da região de $U_{\min }$. As diferenças mais perceptíveis foram observadas no ensaio de expansão, que foi sempre maior com o leito preenchido com as partículas de 2,16 mm, sendo que essa diferença foi mais acentuada empregando-se elevadas velocidades ascensionais.

É interessante observar que inicialmente (no repouso), a porosidade do leito empregando partículas inertes de 2,16 $\mathrm{mm}$ foi ligeiramente menor do que com partículas de $3,08 \mathrm{~mm}$. Isso pode ser explicado pelo fato das partículas menores apresentarem menor efeito de parede, fato este que foi minuciosamente estudado por Zotim (1985) e é amplamente conhecido e investigado por pesquisadores que estudam a caracterização de leitos fixos. À medida que a velocidade foi aumentada, com a conseqüente fluidificação e expansão do leito, as partículas menores começaram a ter maiores valores de porosidade, justamente porque apresentaram maior expansão que as partículas de 3,08 mm, para uma mesma velocidade. Ao se expandirem mais, elas proporcionaram maiores vazios entre si. Certamente que em uma partícula bem definida, como a alumina, essas diferenças seriam mais facilmente visualizadas.

A discussão sobre fluidodinâmica será retomada quando a fluidodinâmica do reator com partículas inertes e biopartículas for comparada. 


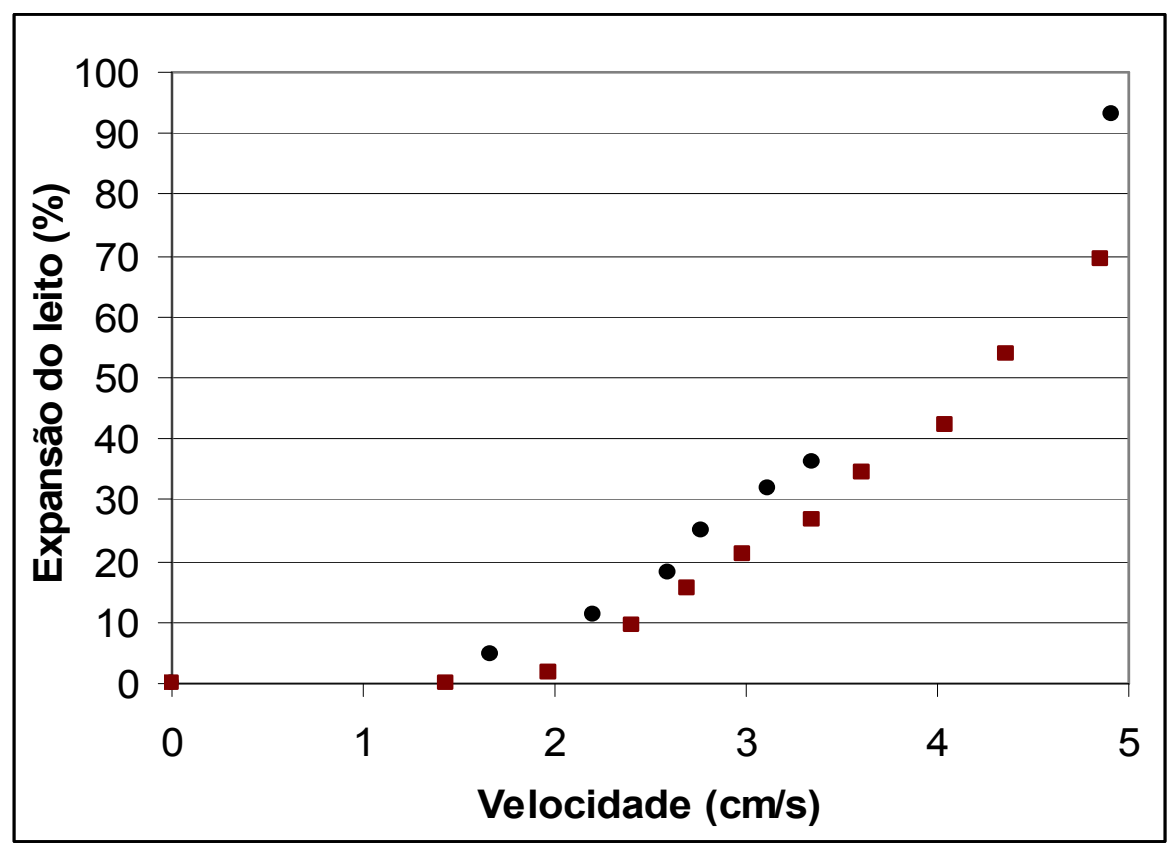

Figura 5.16 - Expansão do leito do reator B preenchido com dois grupos de partículas inertes de carvão ativado.

(• ) grupo I: partículas com diâmetro médio de 2,16 mm

(n ) grupo II: partículas com diâmetro médio de 3,08 mm

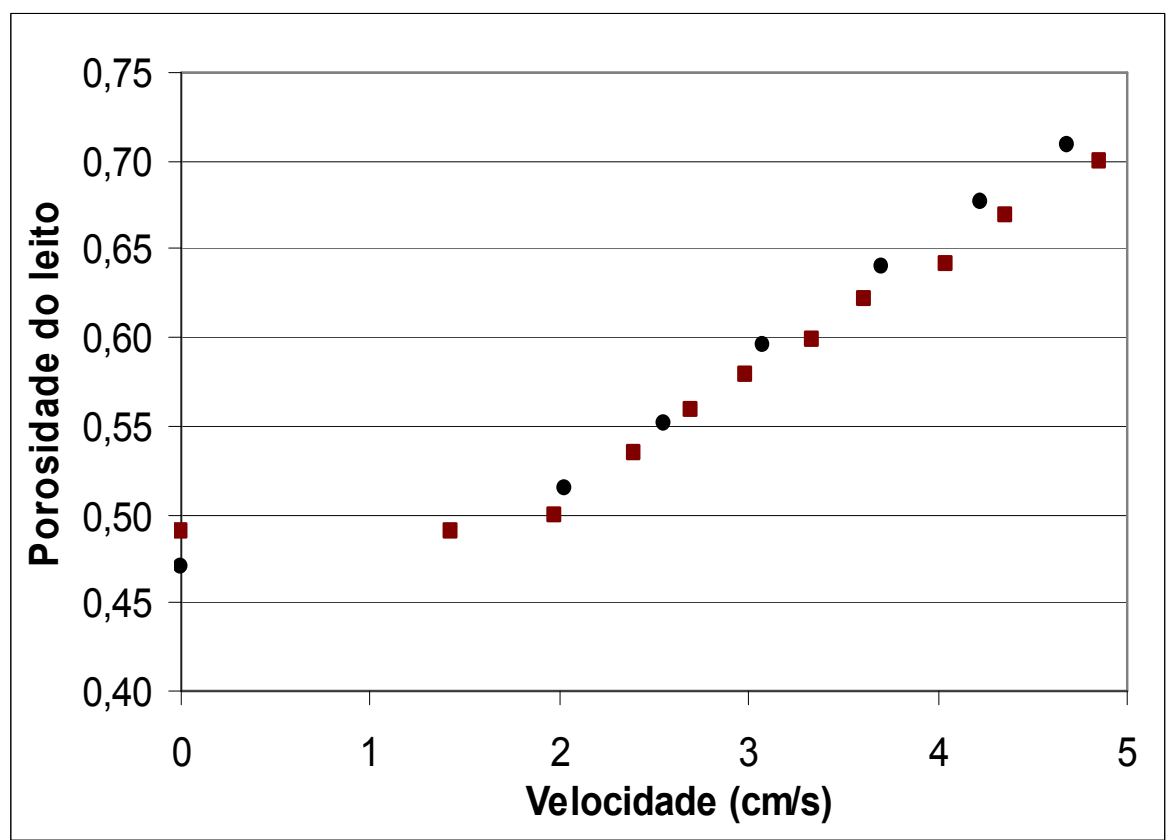

Figura 5.17 - Porosidade do leito do reator B preenchido com dois grupos de partículas inertes de carvão ativado.

(• ) grupo I: partículas com diâmetro médio de 2,16 mm (घ ) grupo II: partículas com diâmetro médio de $3,08 \mathrm{~mm}$. 


\subsubsection{ISOTERMAS DE ADSORÇÃO COM PARTÍCULAS INERTES}

Para facilitar a apresentação dos resultados, a solução contendo somente PCP e água destilada será denominada de solução 1 e a solução contendo efluente sintético e PCP será denominada de solução 2. O ponto relativo à concentração mais alta de $\mathrm{PCP}$ foi descartado no equacionamento da isoterma de Freundlich, pois prejudicava de maneira considerável a qualidade da reta ajustada, segundo avaliação pelo coeficiente de correlação. Entretanto, para a isoterma de Langmuir, nenhum ponto foi descartado. As concentrações nos dois frascos de controle apresentou desvios menores que $1 \%$ após 24 horas.

Os coeficientes $\mathrm{K}^{\prime}$ e b encontrados para a equação 4.6 da isoterma de adsorção da solução 1 em carvão ativado foram, respectivamente, 2,42 (L/mg) e 1,49. O coeficiente de correlação da equação linearizada a partir dos dados experimentais foi de 0,9223. Dessa maneira, a equação de Langmuir para esta situação foi:

$$
\mathrm{W}=\frac{2,42 \cdot 1,49 \cdot C}{1+2,42 \cdot C}
$$

Na qual W é expresso em massa de PCP por massa de carvão $(\mathrm{mg} / \mathrm{g})$ e $\mathrm{C}$ é a concentração de equilíbrio no líquido ( $\mathrm{mg} / \mathrm{L})$.

Os coeficientes "b" e "m" encontrados para a equação 4.7 da isoterma de adsorção da solução 1 em carvão ativado, foram respectivamente, 1,085 $(\mathrm{mg} / \mathrm{g})$ e 0,165 . O coeficiente de correlação para a equação linearizada a partir dos dados experimentais foi de 0,9695. A equação de Freundlich para esta situação foi:

$$
W=1,085 \cdot C^{0,165}
$$

A Figura 5.18 apresenta os pontos experimentais obtidos no ensaio da solução 1 , e as duas isotermas que foram ajustadas a partir destes pontos: 


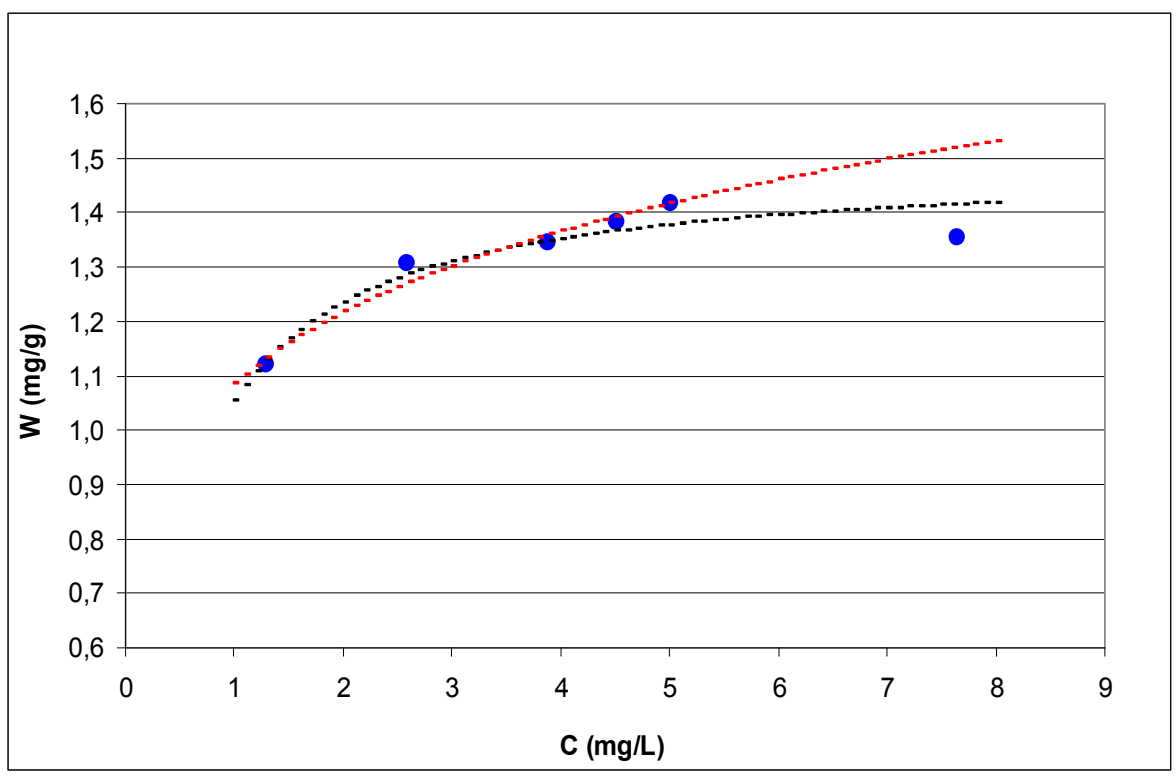

Figura 5.18 - Isotermas de adsorção de Freundlich e Langmuir obtidas para a adsorção da solução 1 em carvão ativado.

\section{(-) Freundlich (-) Langmuir (•) dados experimentais}

Os coeficientes $\mathrm{K}^{\prime}$ e b encontrados para a equação 4.6 da isoterma de adsorção da solução 2 em carvão ativado foram, respectivamente, 1,87 (L/mg) e 1,39. O coeficiente de correlação para a equação linearizada dos dados experimentais foi de 0,9187 . Dessa maneira, a equação de Langmuir para esta situação foi:

$$
\mathrm{W}=\frac{1,87 \cdot 1,39 \cdot C}{1+1,87 \cdot C}
$$

Na qual W é expresso em massa de PCP por massa de carvão $(\mathrm{mg} / \mathrm{g})$ e $C$ é a concentração de equilíbrio no líquido ( $\mathrm{mg} / \mathrm{L})$.

Os coeficientes "b" e "m" encontrados para a equação 4.7 da isoterma de adsorção da solução $1 \mathrm{em}$ carvão ativado, foram respectivamente, 1,005 $(\mathrm{mg} / \mathrm{g})$ e 0,129 . O coeficiente de correlação para a equação linearizada a partir dos dados experimentais foi de 0,9629. A equação de Freundlich para esta situação foi:

$$
W=1,005 \cdot C^{0,129}
$$


A Figura 5.19 apresenta os pontos experimentais obtidos no ensaio da solução 2 e as duas isotermas que foram ajustadas a partir destes pontos:

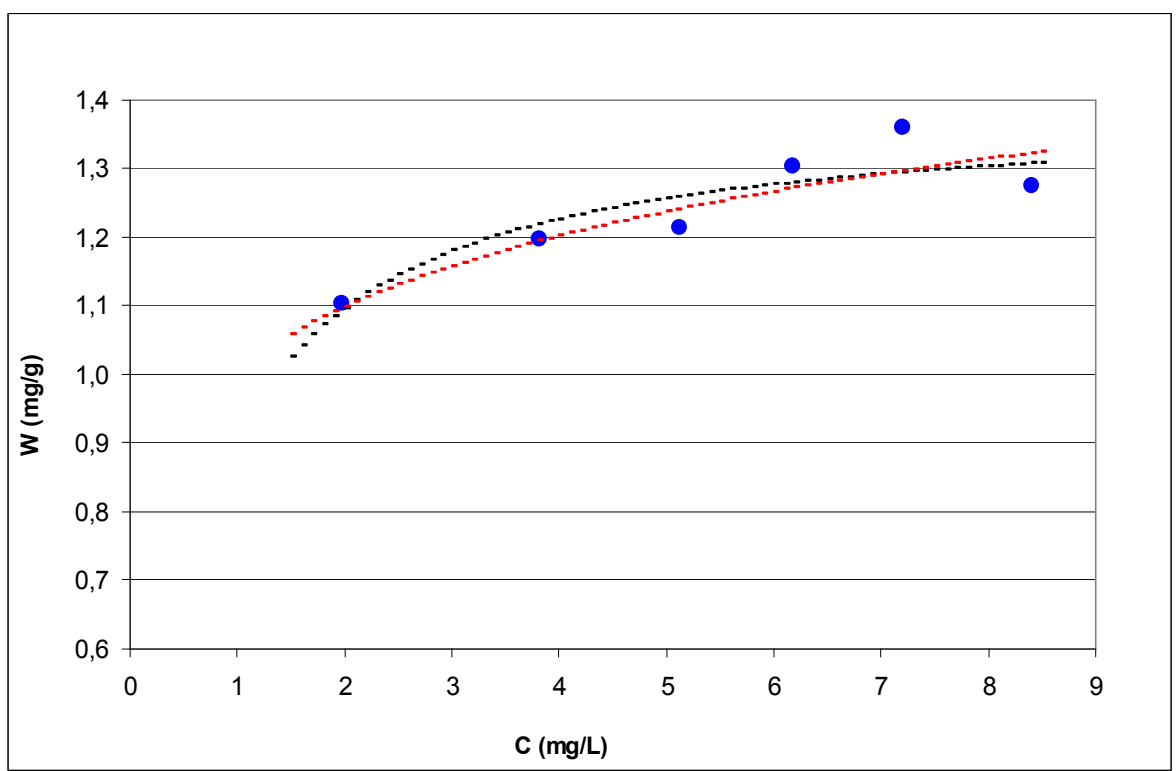

Figura 5.19 - Isotermas de adsorção de Freundlich e Langmuir obtidas para a adsorção da solução 2 em carvão ativado.

\section{(-) Freundlich (-) Langmuir (•) dados experimentais}

A análise das Figuras 5.18 e 5.19 mostra que as duas isotermas apresentaram um ajuste satisfatório aos pontos experimentais. A isoterma de Langmuir, entretanto, ajustou-se melhor a todo intervalo de concentrações que foi utilizado, e a isoterma de Freundlich apresentou desvios significativos a partir da concentração de equilíbrio de $5 \mathrm{mg} / \mathrm{L}$, no ensaio realizado para a solução 1. A Figura 5.20 apresenta as isotermas de Langmuir ajustadas para as duas soluções que foram analisadas.

É interessante observar na Figura 5.20 que a presença de matéria orgânica na solução 2 (em concentração constante) provocou um declínio nas taxas de adsorção de PCP no carvão ativado em comparação à solução 1. Para uma mesma concentração de equilíbrio no líquido, a massa de PCP retida no carvão foi maior na solução 1 . O desvio médio obtido para o intervalo de concentrações utilizado foi em torno de $9 \%$. Esse fato mostra que ocorreu competição pelos sítios ativos entre o PCP e a matéria orgânica presente na solução. 


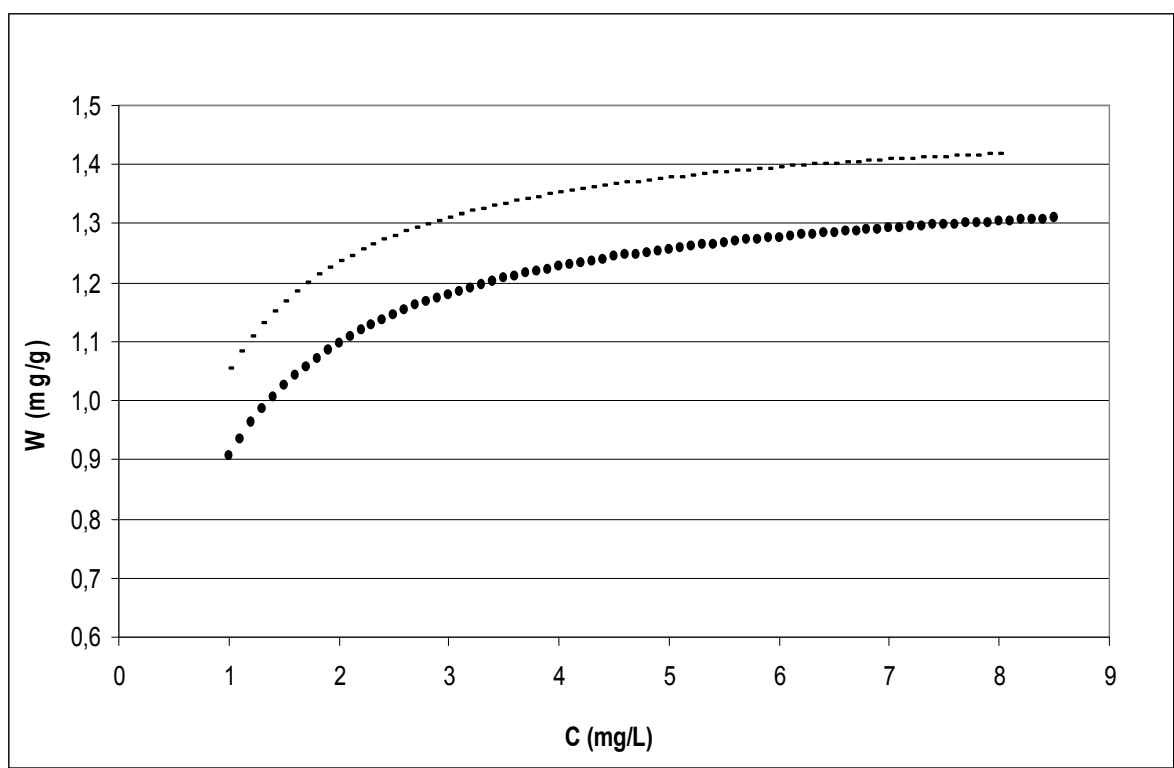

Figura 5.20 - Isotermas de adsorção de Langmuir obtidas para a adsorção da solução 1 e da solução 2 em carvão ativado.

\section{(-) solução $1(\bullet)$ solução 2}

A remoção de PCP em um RALF com carvão ativado ocorreu tanto por processos biológicos como por adsorção no meio suporte. Entretanto, esses dois fenômenos acontecem em escalas de tempo distintas. No caso da adsorção, constatou-se que nas primeiras 3 horas dos experimentos para determinação das isotermas, mais de $95 \%$ do PCP (em relação a concentração de equilíbrio) já havia sido adsorvido, e no máximo em 12 horas era atingida a concentração de equilíbrio. No reator, a situação é um pouco diferente dos ensaios em batelada para a determinação das isotermas, porém é possível utilizar-se da hipótese de que o equilíbrio dinâmico atingido tem um valor muito próximo do obtido na situação sem escoamento. Portanto, para este tipo de configuração, em princípio, o equilíbrio dinâmico da adsorção também já deve ter sido atingido em aproximadamente em 12 horas. Assim, em experimentos biológicos superiores a esse tempo, a remoção do PCP deverá ocorrer predominantemente por atividade biológica.

\subsubsection{INTERAÇÃO ENTRE AS BIOPARTÍCULAS E O FLUIDO}

As interações entre as biopartículas e o fluido foram analisadas através de ensaios de fluidodinâmica (no reator B). Um dos objetivos mais importantes 
do trabalho consistiu justamente em verificar a influência da biomassa na fluidodinâmica de reatores, tanto pela importância da fluidodinâmica no desempenho dos reatores, como também pelo reduzido número de pesquisas encontradas na literatura que tratam do assunto.

Para tanto, uma análise mais aprofundada dos resultados obtidos para o reator B com as biopartículas será efetuada posteriormente, quando uma comparação geral da fluidodinâmica (com e sem biomassa) for feita. Antes, porém, serão apresentados os resultados obtidos para os ensaios de velocidade terminal, tanto para partícula inerte como biopartícula, que foram importantes para completar a comparação.

Após o último ensaio fluidodinâmico com partículas inertes, ou seja, com partículas de 3,08 $\mathrm{mm}$ de diâmetro, o reator $B$ foi submetido a um processo de inoculação e colocado em condições normais de operação. Após um período de operação estável (cerca de 60 dias) em que foram mantidas as mesmas condições, foram realizados os ensaios fluidodinâmicos com biopartículas. A Tabela 5.9 mostra os parâmetros operacionais em que se encontrava o reator B no momento que antecedeu os ensaios fluidodinâmicos.

Tabela 5.9 - Informações e parâmetros operacionais do RALF B no momento dos ensaios fluidodinâmicos com biopartículas.

\begin{tabular}{cc}
\hline INFORMAÇÃO & DESCRIÇÃO \\
\hline Dias de operação & 60 \\
Diâmetro de partícula (mm) & 3,08 \\
DQO afluente (mg/L) & 500 \\
TDH (horas) & 8,0 \\
Vazão afluente (L/dia) & 6,6 \\
C.O. (g DQO/dia) & 3,08 \\
T.C.O. (g DQO/L.dia) & 1,40 \\
Altura estática do leito (cm) & 24 \\
Quantidade de biomassa (mgSSV / gCAG) & 2,8 \\
Expansão do leito (\%) & 35 \\
\hline Obs.: $\quad$ C.O.: carga orgânica &
\end{tabular}


A Figura 5.21 mostra a curva característica obtida para o reator preenchido com as biopartículas. Para esta situação, as duas regiões ( $A$ e B) foram claramente visualizadas e o valor de $U_{\min }$, por volta de $2 \mathrm{~cm} / \mathrm{s}$ (ou 72 $\mathrm{m} / \mathrm{h}$ ), também foi determinado sem dificuldades. As Figuras 5.22 e 5.23 mostram, respectivamente, os resultados obtidos para a expansão do leito e a porosidade.

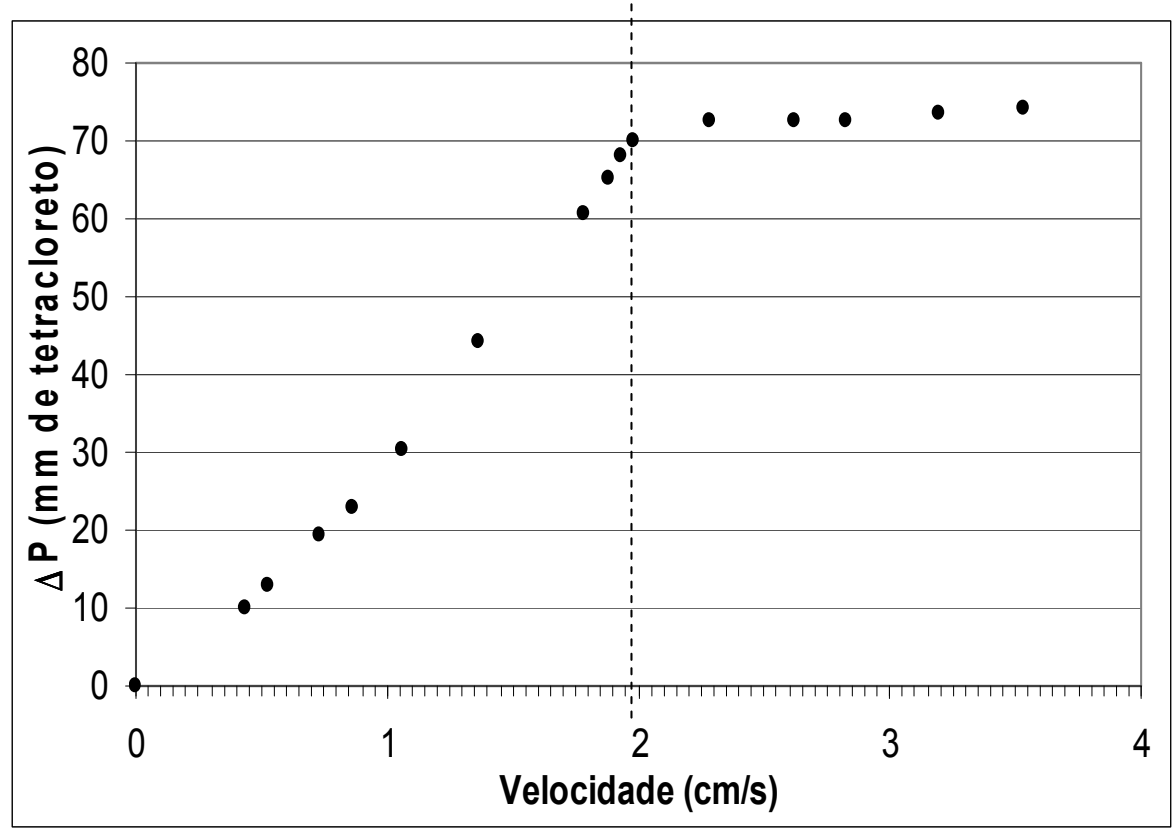

Figura 5.21 - Curva característica para o reator B preenchido com biopartículas.

Em virtude da experiência adquirida com o reator $A$, e os ensaios fluidodinâmicos terem mostrado uma reprodutibilidade satisfatória, todos os ensaios no reator $B$ foram feitos em duplicata, e não mais em triplicata. $A$ quantidade menor de pontos obtidos em relação ao reator $A$ se deve ao fato do reator B possuir uma altura do leito bem menor (550 mm contra $1200 \mathrm{~mm}$ ). Dessa maneira, com o aumento da velocidade ascensional logo era atingida a altura máxima de expansão possível sem que ocorresse expulsão das biopartículas. Por segurança, nos ensaios com biopartículas procurou-se trabalhar um pouco abaixo da expansão máxima possível, para que não ocorresse um cisalhamento demasiado do biofilme. 
Novamente, muito semelhante aos ensaios fluidodinâmicos sem biomassa, foi possível perceber as duas regiões típicas de leitos fluidificados bifásicos.

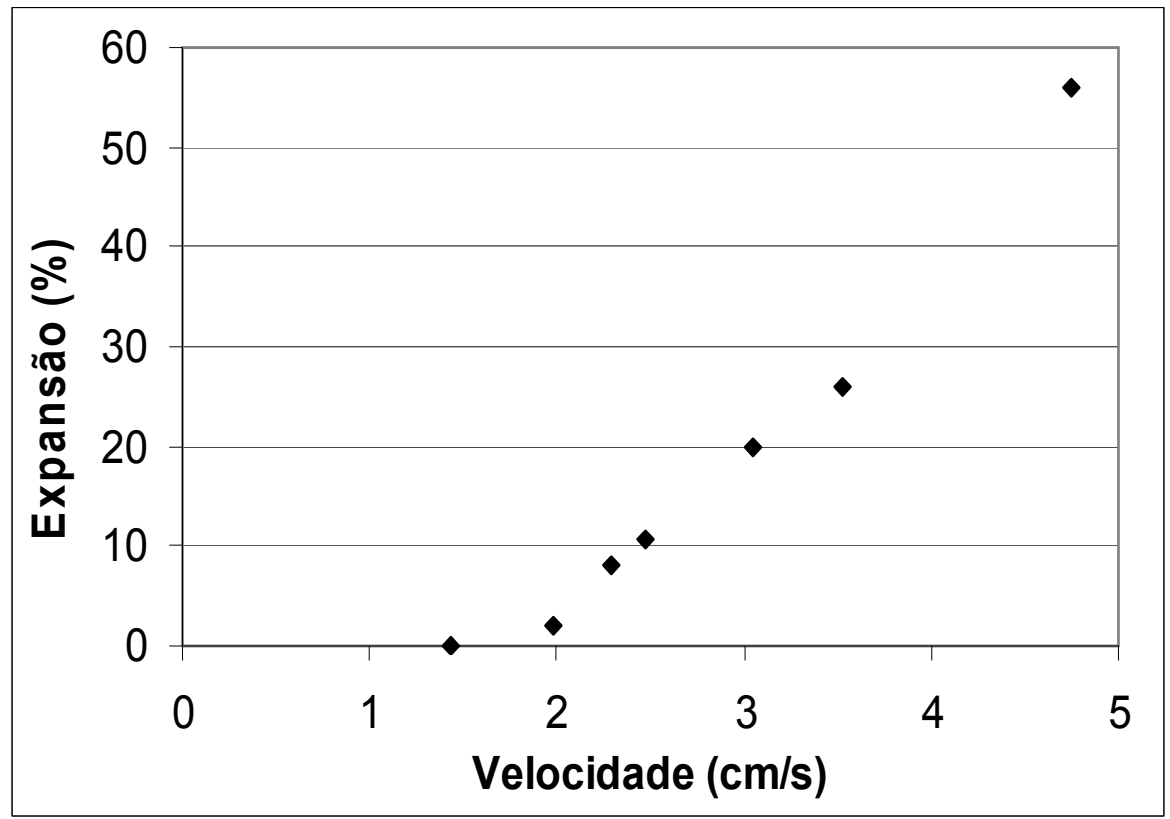

Figura 5.22 - Expansão do leito do reator B preenchido com biopartículas.

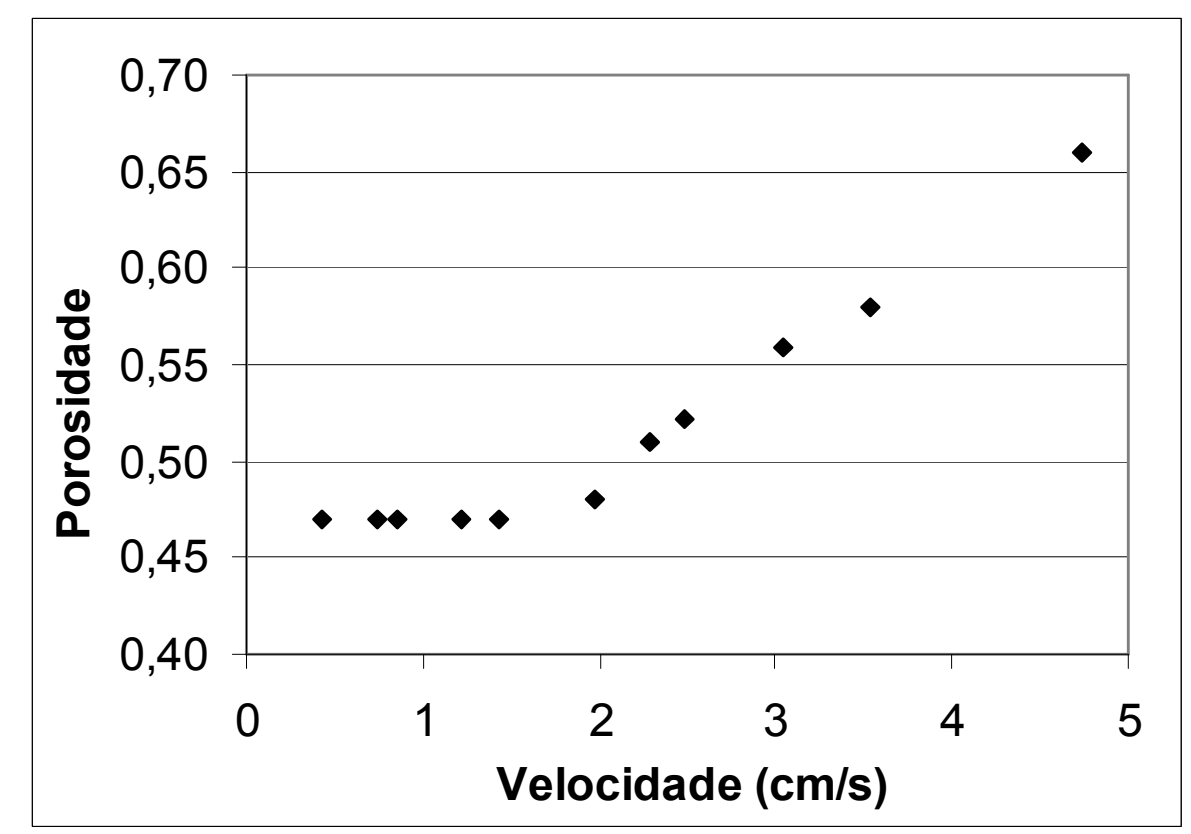

Figura 5.23 - Porosidade do leito do reator B preenchido com biopartículas. 
Os resultados obtidos aqui são discutidos de maneira mais aprofundada no item 5.3.5, quando uma análise geral das principais diferenças entre a fluidodinâmica com partículas inertes e biopartículas é apresentada.

\subsubsection{INTERAÇÃO ENTRE PARTÍCULA INERTE E FLUIDO}

Vários testes iniciais foram realizados na coluna, através da utilização da partícula de carvão e da medição de sua velocidade terminal em relação a diferentes distâncias. Percebeu-se que, devido à baixa densidade das partículas, poucos centímetros de deslocamento da partícula, partindo do repouso foram suficientes para garantir a velocidade constante. Dessa maneira, qualquer dupla de pontos selecionada a partir do ponto número 1 estaria apropriada para uma boa estimativa da velocidade terminal. Por esse motivo, a distância entre os pontos 2 e 4 (Figura 4.11) foi escolhida como padrão para todos os ensaios, por este intervalo ser considerado o mais "cômodo" para as medições.

A Tabela 5.10 mostra os valores obtidos para velocidade terminal das 50 partículas inertes isoladas. Os dados obtidos forneceram uma velocidade terminal média da partícula inerte de $8,2 \mathrm{~cm} / \mathrm{s}$, com um desvio padrão de 0,5 $\mathrm{cm} / \mathrm{s}$. Como foi observado, para uma relação entre diâmetro de partícula $\left(d_{p}\right)$ e diâmetro de tubo $\left(d_{t}\right)$ próxima a 0,05 , o valor de $U_{t}$ se torna uma adequada aproximação da velocidade terminal da partículas isolada $\left(U_{\infty}\right)$.

Um gráfico com os valores obtidos para $U_{t}$ (Figura 5.24) além da dispersão calculada demonstram claramente a observação que já foi feita várias vezes no que diz respeito à irregularidade da partícula de carvão ativado. 
Tabela 5.10 - Velocidades terminais das partículas inertes de carvão ativado obtidas em ensaio de coluna.

\begin{tabular}{ccc|ccc}
\hline Partícula & Tempo $(\mathbf{s e g})$ & $\mathbf{U}_{\mathbf{t}}(\mathbf{c m} / \mathbf{s})$ & Partícula & Tempo $(\mathbf{s e g})$ & $\left.\mathbf{U}_{\mathbf{t}} \mathbf{( c m} / \mathbf{s}\right)$ \\
\hline $\mathbf{1}$ & 4,6 & 8,7 & & & \\
$\mathbf{2}$ & 5,0 & 8,0 & $\mathbf{2 7}$ & 5,5 & 7,3 \\
$\mathbf{3}$ & 4,5 & 8,9 & $\mathbf{2 8}$ & 5,0 & 8,0 \\
$\mathbf{4}$ & 5,5 & 7,3 & $\mathbf{2 9}$ & 5,5 & 7,3 \\
$\mathbf{5}$ & 5,0 & 8,0 & $\mathbf{3 0}$ & 4,5 & 8,9 \\
$\mathbf{6}$ & 4,5 & 8,9 & $\mathbf{3 1}$ & 4,9 & 8,2 \\
$\mathbf{7}$ & 5,0 & 8,0 & $\mathbf{3 2}$ & 4,8 & 8,3 \\
$\mathbf{8}$ & 5,5 & 7,3 & $\mathbf{3 3}$ & 4,7 & 8,5 \\
$\mathbf{9}$ & 4,8 & 8,3 & $\mathbf{3 4}$ & 4,6 & 8,7 \\
$\mathbf{1 0}$ & 5,0 & 8,0 & $\mathbf{3 5}$ & 4,7 & 8,5 \\
$\mathbf{1 1}$ & 4,9 & 8,2 & $\mathbf{3 6}$ & 4,5 & 8,9 \\
$\mathbf{1 2}$ & 5,2 & 7,7 & $\mathbf{3 7}$ & 5,4 & 7,4 \\
$\mathbf{1 3}$ & 5,2 & 7,7 & $\mathbf{3 8}$ & 5,0 & 8,0 \\
$\mathbf{1 4}$ & 4,6 & 8,7 & $\mathbf{3 9}$ & 5,2 & 7,7 \\
$\mathbf{1 5}$ & 4,6 & 8,7 & $\mathbf{4 0}$ & 4,9 & 8,2 \\
$\mathbf{1 6}$ & 5,5 & 7,3 & $\mathbf{4 1}$ & 4,6 & 8,7 \\
$\mathbf{1 7}$ & 4,6 & 8,7 & $\mathbf{4 2}$ & 5,0 & 8,0 \\
$\mathbf{1 8}$ & 4,5 & 8,9 & $\mathbf{4 3}$ & 4,5 & 8,9 \\
$\mathbf{1 9}$ & 5,4 & 7,4 & $\mathbf{4 4}$ & 4,6 & 8,7 \\
$\mathbf{2 0}$ & 4,7 & 8,5 & $\mathbf{4 5}$ & 4,7 & 8,5 \\
$\mathbf{2 1}$ & 5,0 & 8,0 & $\mathbf{4 6}$ & 4,5 & 8,9 \\
$\mathbf{2 2}$ & 5,3 & 7,5 & $\mathbf{4 7}$ & 5,2 & 7,7 \\
$\mathbf{2 3}$ & 5,5 & 7,3 & $\mathbf{4 8}$ & 5,0 & 8,0 \\
$\mathbf{2 4}$ & 4,7 & 8,5 & $\mathbf{4 9}$ & 4,7 & 8,5 \\
$\mathbf{2 5}$ & 4,6 & 8,7 & $\mathbf{5 0}$ & 4,9 & 8,2 \\
$\mathbf{2 6}$ & 5,2 & 7,7 & $\mathbf{m e ́ d i a}$ & $\mathbf{4 , 9}$ & $\mathbf{8 , 2}$ \\
\hline
\end{tabular}

Dessa maneira, adotando-se para $U_{\infty}$ os valores obtidos para $U_{t}$ no ensaio em coluna, e utilizando os valores de velocidade ascensional $(U)$ e porosidade $(\varepsilon)$ que foram obtidos nos ensaios anteriores, um gráfico com a equação linearizada de Richardson \& Zaki (Figura 5.25) fornece como coeficiente angular o valor da constante empírica $\mathrm{n}$. Assim, é possível prever a porosidade do leito preenchido por partículas inertes para qualquer valor de velocidade ascensional. 


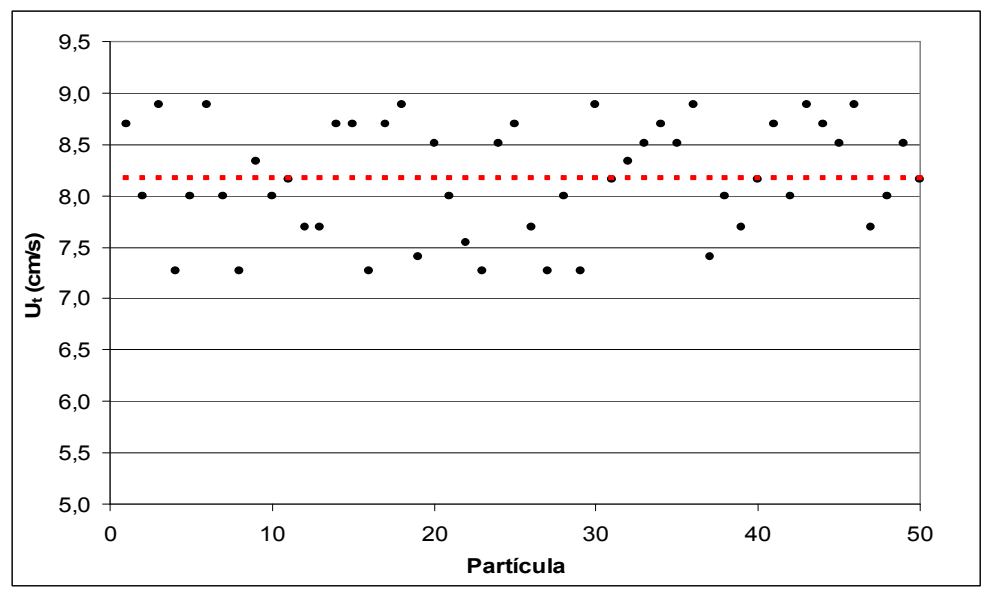

Figura 5.24 - Velocidades terminais obtidas para as $\mathbf{5 0}$ partículas inertes de carvão ativado. (•) valor de cada partícula ( $($ ) valor médio

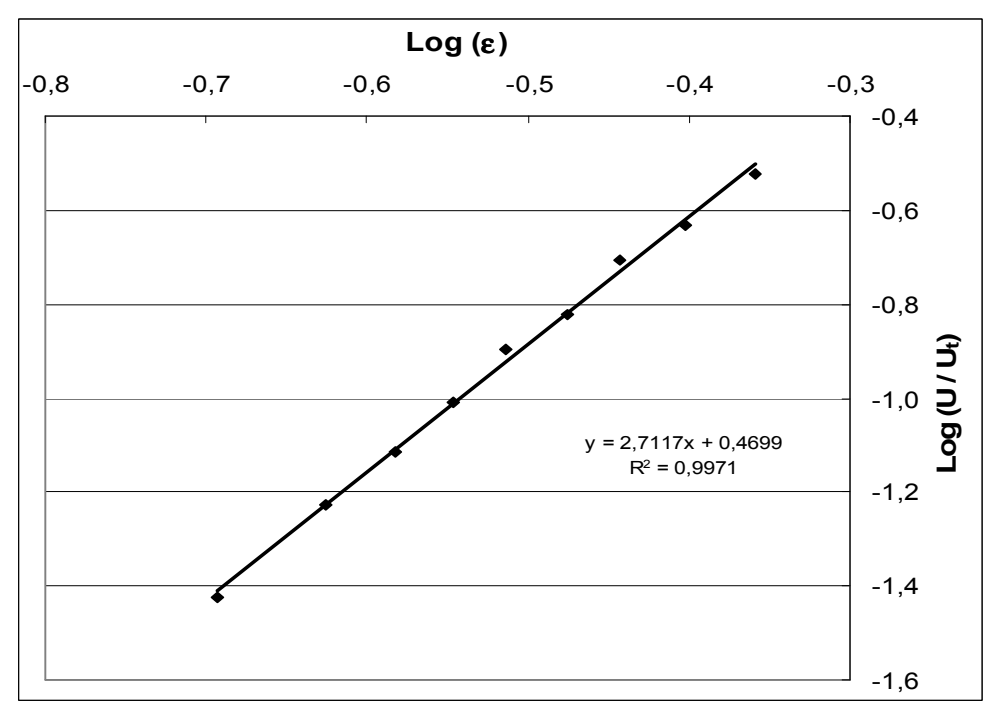

Figura 5.25 - Gráfico com a equação de Richardson \& Zaki linearizada, para determinação da constante empírica $n$, através de valores experimentais de velocidade terminal, para partículas inertes com diâmetro de $3,08 \mathrm{~mm}$.

O gráfico com a equação linearizada de Richardson \& Zaki para as partículas inertes forneceu o valor 2,71 para o coeficiente empírico $\mathrm{n}$. Finalmente, a equação final para este caso em particular, na qual $U$ é expresso $\mathrm{em} \mathrm{cm} / \mathrm{s}$, foi a seguinte:

$$
U=8,2 . \varepsilon^{2,71}
$$




\subsubsection{INTERAÇÃO ENTRE BIOPARTÍCULA E FLUIDO}

O ensaio para determinação da velocidade terminal da biopartícula foi realizado em 4 etapas, totalizando 50 biopartículas de carvão ativado, com diâmetro médio de peneira de $3,08 \mathrm{~mm}$, retiradas do reator $B$ após os ensaios de fluidodinâmica. Cada etapa de ensaios foi realizada com um intervalo de 20 dias, e contou com 10 partículas, com exceção da última, feita com 20 partículas. O reator $B$ estava nas mesmas condições operacionais que foram descritas na Tabela 5.9 deste capítulo de resultados, na página 122. As mesmas condições operacionais foram mantidas para a coleta de amostras para realização das outras 3 etapas.

A Tabela 5.11 mostra os valores obtidos para velocidade terminal das 50 biopartículas. Os dados obtidos forneceram uma velocidade terminal média da biopartícula de $9,5 \mathrm{~cm} / \mathrm{s}$, com um desvio padrão de $0,5 \mathrm{~cm} / \mathrm{s}$.

Tabela 5.11 - Velocidades terminais das biopartículas de carvão ativado obtidas em ensaio de coluna.

\begin{tabular}{|c|c|c|c|c|c|}
\hline Partícula & Tempo (seg) & $U_{t}(\mathrm{~cm} / \mathrm{s})$ & Partícula & Tempo (seg) & $U_{t}(\mathrm{~cm} / \mathrm{s})$ \\
\hline 1 & 4,0 & 10,0 & & & \\
\hline 2 & 4,7 & 8,5 & 27 & 4,0 & 10,0 \\
\hline 3 & 4,0 & 10,0 & 28 & 4,1 & 9,8 \\
\hline 4 & 4,7 & 8,5 & 29 & 4,3 & 9,3 \\
\hline 5 & 4,0 & 10,0 & 30 & 4,0 & 10,0 \\
\hline 6 & 4,6 & 8,7 & 31 & 4,5 & 8,9 \\
\hline 7 & 4,6 & 8,7 & 32 & 4,0 & 10,0 \\
\hline 8 & 4,0 & 10,0 & 33 & 4,1 & 9,8 \\
\hline 9 & 4,0 & 10,0 & 34 & 4,4 & 9,1 \\
\hline 10 & 4,3 & 9,3 & 35 & 4,3 & 9,3 \\
\hline 11 & 4,6 & 8,7 & 36 & 4,2 & 9,5 \\
\hline 12 & 4,6 & 8,7 & 37 & 4,6 & 8,7 \\
\hline 13 & 4,4 & 9,1 & 38 & 4,1 & 9,8 \\
\hline 14 & 4,0 & 10,0 & 39 & 4,0 & 10,0 \\
\hline 15 & 4,4 & 9,1 & 40 & 4,0 & 10,0 \\
\hline 16 & 4,5 & 8,9 & 41 & 4,0 & 10,0 \\
\hline 17 & 4,5 & 8,9 & 42 & 4,6 & 8,7 \\
\hline 18 & 4,0 & 10,0 & 43 & 4,2 & 9,5 \\
\hline 19 & 4,3 & 9,3 & 44 & 4,4 & 9,1 \\
\hline 20 & 4,3 & 9,3 & 45 & 4,2 & 9,5 \\
\hline 21 & 4,0 & 10,0 & 46 & 4,0 & 10,0 \\
\hline 22 & 4,0 & 10,0 & 47 & 4,1 & 9,8 \\
\hline 23 & 4,4 & 9,1 & 48 & 4,0 & 10,0 \\
\hline 24 & 4,0 & 10,0 & 49 & 4,5 & 8,9 \\
\hline 25 & 4,1 & 9,8 & 50 & 4,0 & 10,0 \\
\hline 26 & 4,2 & 9,5 & média & 4,236 & 9,5 \\
\hline
\end{tabular}


Os valores encontrados para $U_{t}$ das biopartículas foram, em média, maiores do que os valores encontrados para $U_{t}$ das partículas inertes, o que será discutido a seguir no tópico 5.3.5, com auxílio dos resultados dos ensaios de fluidodinâmica.

Um gráfico com os valores experimentais obtidos para $U_{t}$ (Figura 5.26) mostra que a "nuvem" de pontos foi distribuída de maneira muito similar para todos os grupos de partículas analisados.

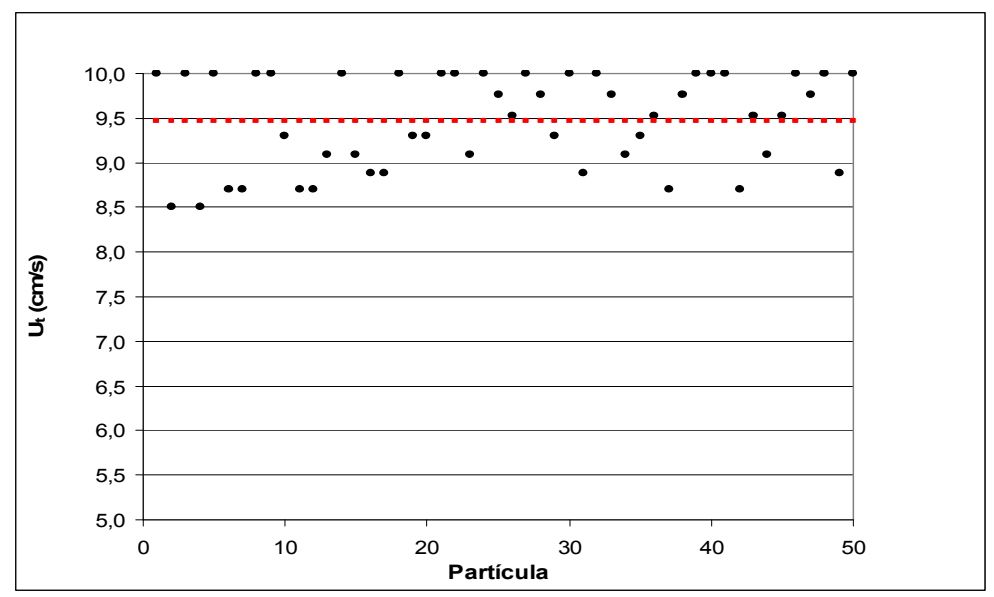

Figura 5.26 - Velocidades terminais obtidas para as 50 biopartículas de carvão ativado. $(\bullet)$ valor de cada partícula ( $\square$ ) valor médio

O gráfico a partir da equação linearizada de Richardson \& Zaki (Figura 5.27) forneceu como coeficiente angular o valor da constante empírica $n$ para o leito preenchido com biopartículas. Da mesma maneira, foi possível prever a porosidade do leito para qualquer valor de velocidade ascensional.

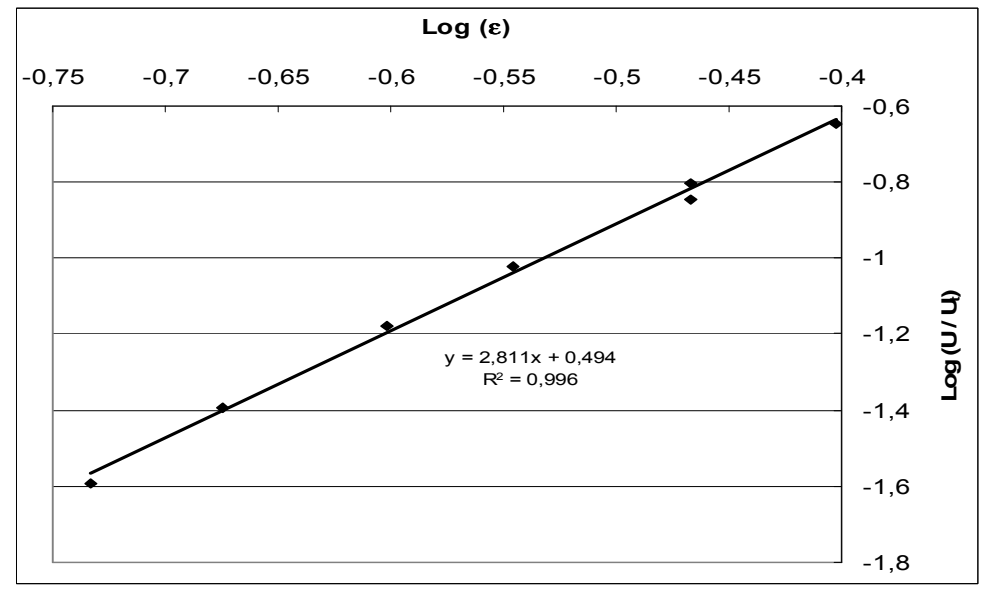

Figura 5.27 - Gráfico com a equação de Richardson \& Zaki linearizada, para determinação da constante empírica $n$, através de valores experimentais de velocidade terminal. 
O gráfico com a equação linearizada de Richardson \& Zaki para as biopartículas forneceu o valor 2,81 para o coeficiente empírico $n$. Finalmente, a equação final para este caso em particular, com $U$ expresso $\mathrm{em} \mathrm{cm} / \mathrm{s}$, foi a seguinte:

$$
U=9,5 . \varepsilon^{2,81}
$$

\subsubsection{DISCUSSÃO GERAL SOBRE OS EFEITOS DA BIOMASSA NO COMPORTAMENTO DO LEITO}

A Figura 5.28 mostra uma comparação entre a curva característica obtida para as partículas inertes e para as biopartículas, com diâmetro de 3,08 $\mathrm{mm}$. Convém repetir que para se obter uma análise mais representativa, não houve troca de partículas, ou seja, as partículas inertes que foram analisadas são as mesmas que, após o processo de inoculação, deram origem às biopartículas. A presença de biomassa imobilizada aumentou em $5 \%$ o valor de $\cup_{\text {min. }}$ Embora essa diferença não seja significativa, já que usualmente os reatores RALF são projetados para operar com velocidades ascensionais bem superiores a $U_{\min }$ (geralmente para expansões do leito maiores que $30 \%$ ), isso mostra que, nesse caso específico, ou seja, nas condições experimentais descritas anteriormente, a imobilização de biomassa tornou as biopartículas mais densas, o que também pode ser verificado analisando-se as pressões de trabalho. Partículas mais pesadas proporcionam quedas de pressão mais elevadas. De fato, no leito preenchido com biopartículas, as pressões foram, no mínimo $10 \mathrm{~mm}$ de tetracloreto maiores do que no leito preenchido com partículas inertes, para velocidades ascensionais superiores a $U_{\text {min }}$. 


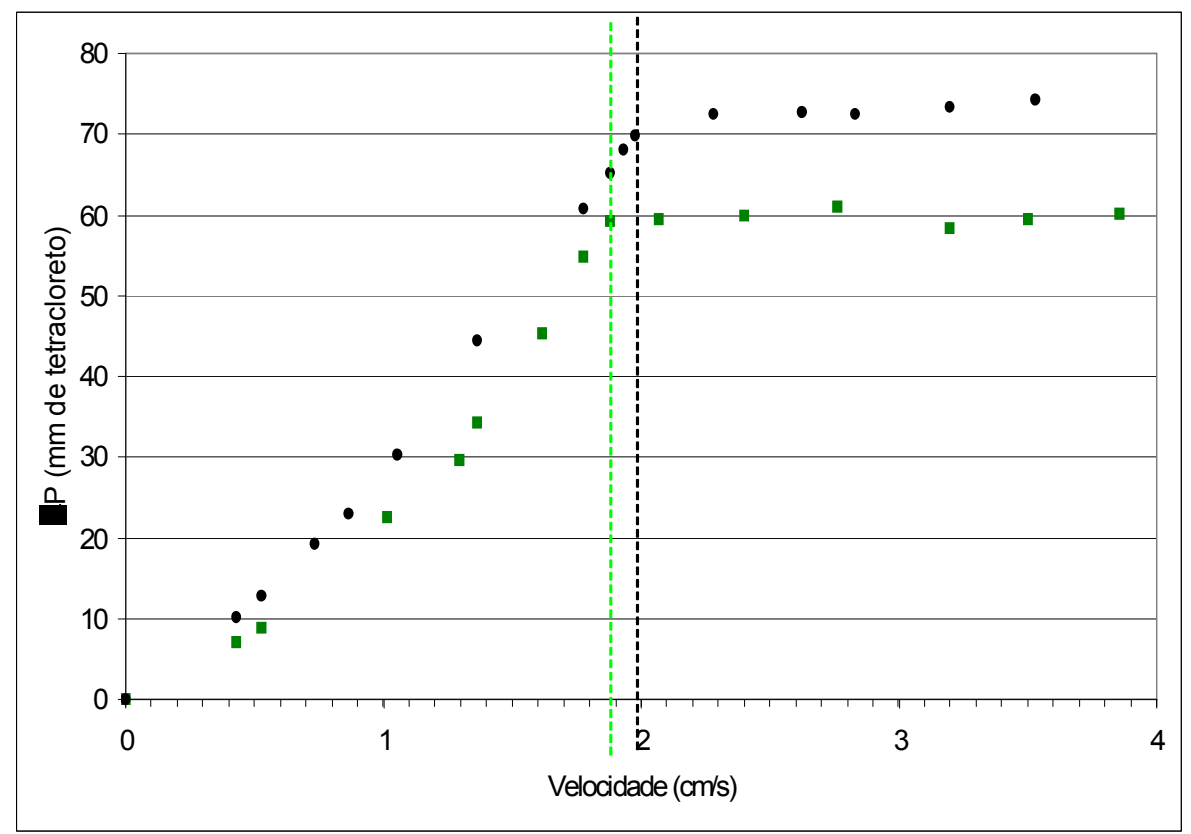

Figura 5.28 - Curva característica para o reator B preenchido com partículas de carvão ativado de 3,08 $\mathrm{mm}$ de diâmetro, com indicação da velocidade de mínima fluidificação.

$(\bullet)$ biopartículas ( $\square$ )partículas inertes

O aumento da densidade da biopartícula foi confirmado posteriormente em todos os outros parâmetros analisados, tais como a porosidade e a expansão do leito (Figura 5.29). Optou-se por não apresentar o gráfico de porosidade do leito pois seu comportamento é similar aos resultados obtidos para expansão do leito, até porque os valores de porosidade são obtidos através de cálculos de volumes que levam em consideração os valores de expansão. No que diz respeito à expansão, o leito com biopartículas apresentou expansões menores do que o leito com partículas inertes, e essa diferença se fez mais acentuada quando foram aplicadas velocidades mais elevadas. 


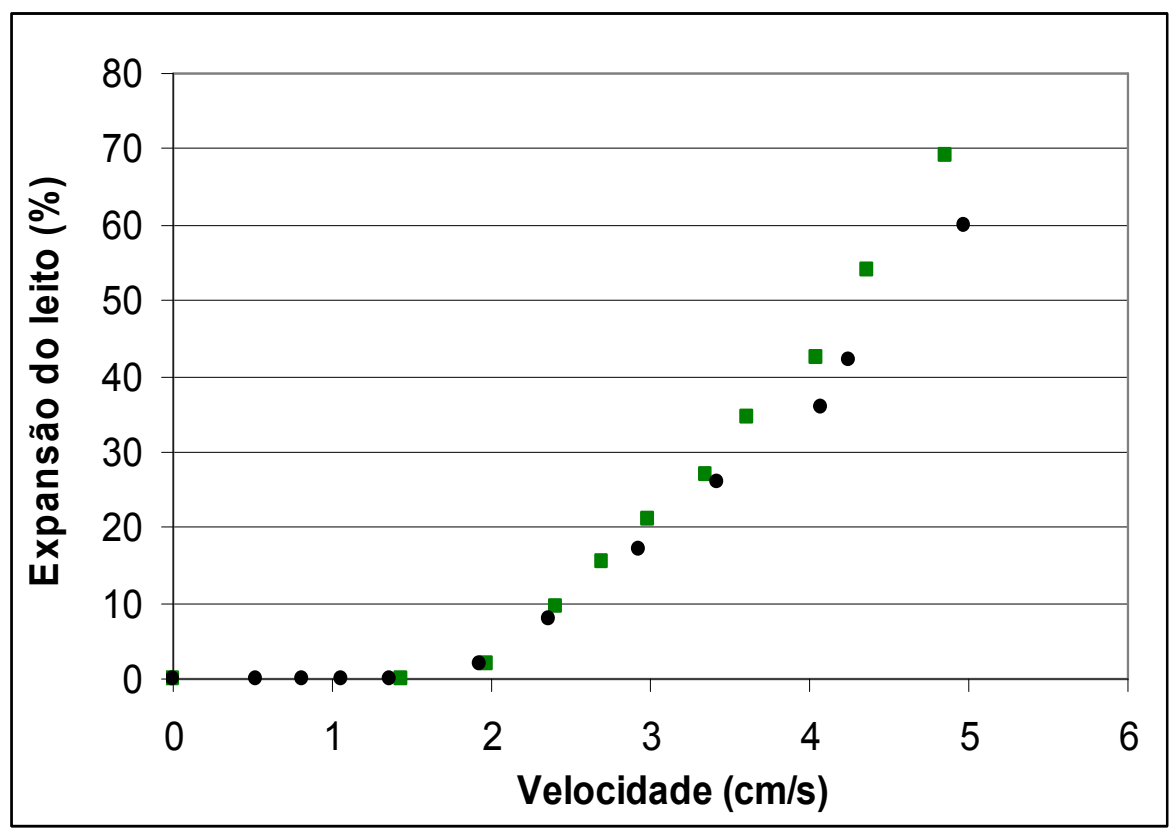

Figura 5.29 - Expansão do leito para o reator B preenchido com partículas de carvão ativado de $3,08 \mathrm{~mm}$ de diâmetro

(•) biopartículas ( $\square$ )partículas inertes

É interessante observar que esses resultados diferem dos resultados obtidos por Diez-Blanco et al. (1995), um dos trabalhos "clássicos" que analisaram a influência da biomassa no comportamento de reatores. Os pesquisadores utilizaram, como meio suporte do reator anaeróbio de leito fluidizado, partículas de sepiolita com cerca de $0,5 \mathrm{~mm}$ de diâmetro. A sepiolita (silicato básico hidratado de magnésio) é uma pedra cerâmica porosa, de coloração branca, cinza-clara ou amarelo-clara, extremamente leve, absorvente e compacta, encontrada especialmente na Ásia. No trabalho, os autores verificaram que o leito preenchido com biopartículas teve uma expansão maior do que quando o leito estava preenchido apenas com a partícula inerte, para uma mesma velocidade ascensional.

Os autores creditaram tal comportamento à diminuição da densidade do conjunto, causada pela adesão de biomassa, em termos de sólidos voláteis, porém não apresentam outras investigações experimentais que confirmem essa colocação (como a velocidade de mínima fluidificação e a velocidade terminal, por exemplo). É conveniente salientar, entretanto, que os resultados obtidos pelos pesquisadores não são conflitantes com os obtidos aqui nesta pesquisa, já que em Diez-Blanco et al. (1995) os pesquisadores utilizaram um 
material suporte com características totalmente diferentes do carvão ativado, inclusive com diâmetros bem menores. Dessa maneira, a possibilidade de comparações fica restrita. Entretanto, foi possível se obter uma melhor percepção dos fatores que interferem no processo.

Muitos pesquisadores citam os resultados obtidos por Diez-Blanco como "referência" de comportamento, o que de certa forma é arriscado, pois não foram encontrados outros trabalhos que avaliam 0 comportamento fluidodinâmico para outras situações experimentais. Afirmar, por exemplo, que a densidade das biopartículas decresce em relação às partículas inertes está relacionado intimamente a muitas condições particulares.

A constatação mais importante em toda essa análise é de que o comportamento fluidodinâmico de reatores anaeróbios de leito fluidificado dependerá em grande parte do tipo, forma, e das dimensões do meio suporte utilizado, e também das condições experimentais e operacionais aplicadas. Diez-Blanco et al. (1995), por exemplo, apresentam a evolução do biofilme ao longo do tempo para as diferentes cargas orgânicas aplicadas ao experimento, mas não informam se o reator, no período situado entre os ensaios de expansão, permaneceu sob as mesmas condições de fluidificação, ou seja, se a expansão era mantida constante, e caso afirmativo, qual era essa expansão.

Sabe-se que uma das vantagens mais difundidas do reator anaeróbio de leito fluidificado é a de proporcionar um ótimo controle na espessura do biofilme. A afirmação é verdadeira, mas é necessário enfatizar que esse controle de espessura está relacionado com uma determinada condição operacional. Uma expansão de $35 \%$ produzirá uma espessura diferente de uma expansão de $55 \%$, e assim por diante. Para cada configuração operacional, é possível um bom controle de espessura do biofilme. Qualquer mudança, entretanto, vai proporcionar uma outra condição de equilíbrio. Além do tipo, forma e dimensão da partícula suporte, a espessura do biofilme e a densidade da biopartícula poderão depender, entre outros fatores, do tempo de operação do reator, da carga orgânica aplicada, da quantidade de material suporte (altura do leito) e da expansão do leito. $\mathrm{O}$ aprisionamento de moléculas de gás no interior da biopartícula provavelmente pode contribuir para a diminuição da densidade, mas quanto a esse fenômeno os autores não fazem qualquer referência. 
A Figura 5.30 mostra um gráfico com os valores obtidos para a velocidade terminal $\left(U_{t}\right)$ para partículas inertes e biopartículas. Essa figura é outra comprovação de que a densidade da partícula aumentou nas condições operacionais aplicadas. Como se observa, foi apropriada a decisão de se coletar um número elevado de partículas para se obter uma média mais confiável.

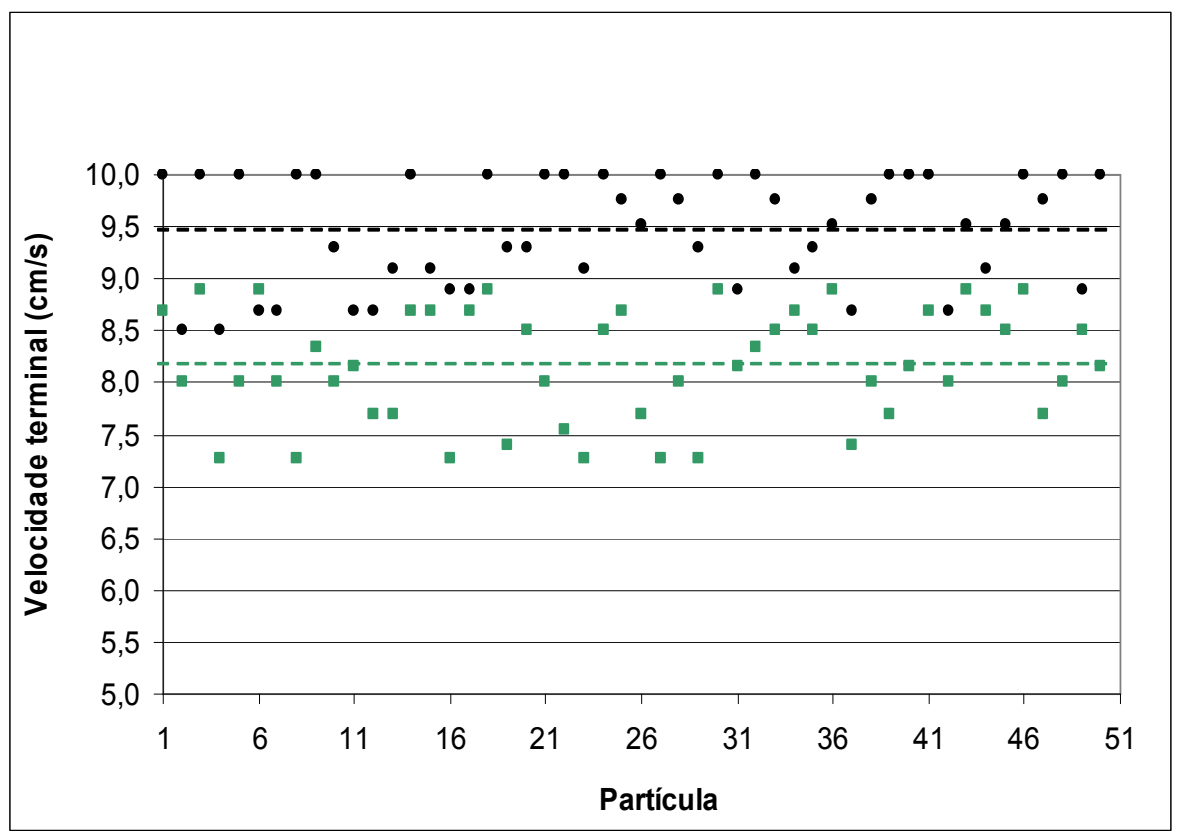

Figura 5.30 - Velocidades terminais e respectivas médias obtidas para as biopartículas e partículas inertes, com diâmetro de $3,08 \mathrm{~mm}$.

Apesar da grande diversidade de valores, causada principalmente pela irregularidade geométrica das partículas, é possível identificar uma tendência de comportamento. Existe claramente uma "nuvem" superior de pontos, representando as biopartículas, e outra inferior, representando as partículas inertes. Os valores médios encontrados para a velocidade terminal das biopartículas e das partículas inertes foram 9,5 e $8,2 \mathrm{~cm} / \mathrm{s}$, respectivamente, e o desvio padrão foi de $0,5 \mathrm{~cm} / \mathrm{s}$ para os dois casos. A velocidade terminal da partícula $\left(U_{t}\right)$ é determinada freqüentemente através de correlações que nem sempre resultam em valores confiáveis. A consideração ou não de fenômenos como o efeito da parede do duto e as forças entre as partículas podem proporcionar diferenças significativas, além do fato de muitos modelos considerarem as partículas como esferas perfeitas, o que gera simplificação no 
caso de partículas como o carvão ativado. Por essas razões, é preferencial que o valor de $U_{t}$ seja obtido experimentalmente.

Correlações que consideram as partículas esféricas para a estimativa da velocidade terminal da partícula introduziriam um grande erro no equacionamento, já que todas as partículas diferem da forma esférica, como foi possível comprovar através de imagens registradas.

Os resultados mostram ainda que os ensaios para determinação de $U_{t}$ nas biopartículas também poderiam ser realizados em uma única etapa, já que não se verificou diferença significativa entre os grupos analisados. As diferenças aconteceram de partícula para partícula, e não têm relação com a espessura do biofilme. Isso mostra que a fluidificação do leito e a manutenção dos mesmos parâmetros operacionais durante o ensaio provocam um controle da espessura do biofilme formado.

Os valores encontrados para a velocidade terminal foram então colocados na equação de Richardson \& Zaki e finalmente os valores do coeficiente $n$ foram obtidos: 2,71 para as partículas inertes e 2,81 para as partículas com biomassa imobilizada. Os valores de $\mathrm{n}$ foram obtidos exclusivamente de investigações experimentais, o que dá mais credibilidade às equações encontradas, pelo menos especificamente para este trabalho.

A equação 3.6 aplicada para as situações do trabalho, ficou da seguinte maneira para o leito com partículas inertes:

$$
U=8,2 \cdot \varepsilon^{2,71}
$$

Da mesma maneira, para o leito com biopartículas:

$$
U=9,5 . \varepsilon^{2,81}
$$

Para comprovar a grande irregularidade geométrica das partículas de carvão ativado, mesmo após o processo de peneiramento, foi utilizado o software Image Pro Plus para análise de imagens, cujos resultados já foram mostrados aqui. Esse software mostrou a discrepância das partículas através de fotografias e da medida dos diâmetros. Foi possível identificar uma grande 
variedade de formas geométricas, sendo que todas foram bem diferentes do formato esférico, e muito diferentes umas das outras. É compreensível que ensaios como o da determinação da velocidade terminal, que leva em consideração cada partícula individualmente, sejam mais suscetíveis a desvios do que ensaios que analisam as propriedades "globais" do leito, ou seja, considerando-o um "conjunto homogêneo", tais como os ensaios de expansão e de velocidade de mínima fluidificação.

O aumento da densidade da biopartícula, causado pela imobilização de biomassa, foi um fator preponderante, e verificado em todas as investigações experimentais. $O$ que era uma "suspeita" nas análises $U_{\text {min }}$ se confirmou posteriormente nos ensaios de expansão (no RALF) e de velocidade terminal (na coluna). As biopartículas proporcionaram um pequeno aumento na velocidade de mínima fluidificação (de 1,9 para $2,0 \mathrm{~cm} / \mathrm{s}$ ) e um aumento mais significativo na velocidade terminal (de 8,2 para $9,5 \mathrm{~cm} / \mathrm{s}$ ). Elas pouco alteraram a expansão do leito para baixas velocidades ascensionais. Diferenças mais significativas foram observadas apenas para velocidades ascensionais elevadas.

Conclui-se finalmente que na análise fluidodinâmica são obtidas informações importantes do comportamento operacional dos reatores, e sempre que possível ela deveria preceder a fase biológica das pesquisas, quase como um pré-requisito. Esse estudo combinado é fundamental para o bom desempenho do processo, pois não fornece apenas as informações qualitativas, que podem ser até intuitivas, mas também uma análise quantitativa do comportamento.

O que se observa, porém, é que na área de tratamento biológico de efluentes, em muitos casos os parâmetros operacionais dos reatores são definidos "a olho", e a falta de um conhecimento prévio do comportamento fluidodinâmico do reator pode acarretar um funcionamento inadequado.

\subsubsection{DIFICULDADES E PROBLEMAS OPERACIONAIS ENCONTRADOS}

Uma observação importante digna de registro foi a impossibilidade do sistema de selo hídrico medir o gás produzido para o reator B. Essa 
particularidade não chegou a ter "status" de problema, já que está mais relacionada com a baixa produção de gás do que com algum problema do aparato experimental, ou seja, foi uma característica particular do experimento. Foram feitos vários testes simples como a colocação de espuma de sabão como indicador, mas o reator não apresentou qualquer tipo de vazamento de gás. Além disso, essa mesma constatação foi feita para o reator $A$, indicando que a baixa produção de gás estava relacionada com as condições experimentais aplicadas. A microscopia das partículas de carvão coletadas no reator A, apresentada no tópico 5.5.3, mostra realmente que as condições aplicadas não favoreceram a presença maciça de população metanogênica.

Possivelmente, a condição que mais influenciou a baixa produção de gás foi a composição simples do efluente. O efluente simplificado pode ter sido seletivo na participação dos microrganismos. A produção de gás, entretanto, foi observada antes do reator ter sido colocado em condições normais de operação como leito fluidificado, ou seja, na fase em que operou como leito fixo. Verificou-se nesta fase a presença de bolhas aprisionadas entre as biopartículas. Um pequeno aumento na vazão de alimentação (apenas para teste), liberava para o topo do reator boa parte dessas bolhas de gás aprisionadas.

Quando houve a mudança no regime de escoamento e o reator foi colocado em fluidificação não foi mais notada a presença do gás. As elevadas velocidades ascensionais "lavaram" o leito particulado, e levaram consigo as bolhas aprisionadas. Essa particularidade da pesquisa acabou apresentando um lado positivo, reforçando favoravelmente as hipóteses adotadas inicialmente nos ensaios de fluidodinâmica. A baixa produção de gás mostrou que foi apropriada a hipótese de considerar o sistema bifásico (líquido / sólido), o que é geralmente admitido em processos anaeróbios, mas nem sempre é comprovado.

Da mesma maneira, Sancinetti (2004) não conseguiu medir o volume de gás produzido através de deslocamento de líquido, e também creditou a baixa produção de metano às condições experimentais de seu trabalho. A autora operou um RALF visando a remoção de fenol, utilizando água residuária sintética semelhante a Del Nery (1987). A autora coloca como hipóteses para tal fenômeno a pequena quantidade de microrganismos metanogênicos, a 
baixa concentração de fenol aplicada e o reduzido tempo de detenção hidráulica, mesmo este sendo de $24 \mathrm{hs}$. A autora analisa ainda que um tempo maior de operação e maiores concentrações de fenol poderiam favorecer o aparecimento de morfologias metanogênicas.

A propósito, observou-se em muitos trabalhos que estudaram o desempenho de reatores anaeróbios, para variadas situações, algum aparato de medição de gás produzido. Porém, em alguns desses trabalhos não há qualquer informação, na parte de resultados, se a produção de gás foi mensurável ou não (KORAN et al., 2001). Desse modo, não se sabe se a informação foi omitida por não fazer parte do escopo do trabalho, ou se aconteceu realmente uma inviabilidade técnica de medir o gás.

Para complementar os ensaios fluidodinâmicos no reator $B$, após os ensaios com DQO de entrada de aproximadamente $500 \mathrm{mg} / \mathrm{L}$ programou-se uma etapa adicional, onde foi previsto um aumento da DQO de entrada para $1000 \mathrm{mg} / \mathrm{L}$, até para repetir as mesmas condições que estavam sendo aplicadas ao reator $A$. Porém, após o reator $B$ funcionar um determinado tempo com DQO de $1000 \mathrm{mg} / \mathrm{L}$, um problema operacional inviabilizou o estudo da fluidodinâmica com o dobro da carga orgânica. Possivelmente por um "pico" de energia no período noturno, o reator apresentou um grande aumento de vazão de recirculação. Como conseqüência, grande parte do carvão ativado foi expulsa do leito e ficou alojada na seção de separação. Além disso, todo o tetracloreto contido no interior do manômetro (que estava conectado ao reator) foi transportado para dentro do reator. O tetracloreto é um composto tóxico aos microrganismos, e foi utilizado para os ensaios fluidodinâmicos por ser extremamente sensível a diferenças de pressão, justamente por sua densidade ser apenas um pouco superior à da água.

Diante do problema, a operação do reator B foi suspensa, todo o equipamento foi desligado, o carvão ativado foi descartado e o reator foi desmontado para limpeza. A idéia era refazer todo o procedimento que foi utilizado para colocar o reator $B$ em operação. Porém, como essa verificação era apenas um complemento do estudo, o prazo para conclusão do trabalho estava restrito, e também devido à elevada demanda de tempo com o reator $A$, optou-se por finalizar a etapa de fluidodinâmica, tendo em vista que importantes informações já haviam sido determinadas. 
Problemas operacionais de reatores anaeróbios de leito fluidificado são bem mais freqüentes que com outras configurações de reatores. Geralmente esses problemas estão relacionados às elevadas vazões de recirculação aplicadas. Qualquer problema na alimentação de um reator de leito fixo, por exemplo, não acarretaria maiores preocupações, já que são aplicadas baixas vazões. Nos reatores tipo RALF, uma oscilação de energia pode alterar em grandes proporções a expansão do leito. Neste trabalho, para os dois reatores, procurou-se manter relativamente constante a expansão do leito (em 35\%). Uma etiqueta adesiva marcando a altura correspondente a essa expansão foi colada nas paredes dos reatores. Quase que diariamente houve a necessidade de se fazer pequenos ajustes para a manutenção dessa expansão.

Santos (2001), operando um RALF tratando esgoto bruto, em escala real na Universidade de São Paulo (campus de São Carlos), com altura total de 14,9 metros, relatou um grave problema operacional causado por uma falha na bóia controladora da bomba de recalque, que provocou a destruição da tubulação de recalque e a perda de praticamente todo o leito de carvão ativado do reator. Acidentes nesta escala são extremamente graves devido às elevadas vazões e pressões existentes nos reatores, mas por sorte não houve vítimas.

Os dois reatores utilizados neste trabalho possuíam placas de distribuição do escoamento no fundo que também impediam a passagem do carvão ativado. Na parte superior, como já foi relatado, existia uma espécie de canal para captação das partículas sólidas, minimizando a expulsão do reator.

\subsection{DESEMPENHO DO REATOR A (SEM A INTRODUÇÃO DO PCP)}

Definida a etapa de avaliação do melhor meio suporte de biomassa, o trabalho se dividiu em duas frentes paralelas. $O$ reator $B$ foi utilizado para investigações ligadas ao escoamento, e o reator $A$ foi colocado em operação para a etapa biológica. Após o processo de inoculação, o reator $A$ foi colocado nas condições típicas de um RALF. Imediatamente após a partida, observou-se a presença de biomassa no efluente, que apresentava uma cor levemente escura (negra). De certa forma esse fato foi considerado normal e esperado, pois é de conhecimento que a biomassa nos reatores de leito fluidificado, 
devido às suas características particulares de escoamento, está presente basicamente na forma imobilizada. Após a inoculação, o reator, que estava em regime de leito fixo, ficou com excesso de biomassa. Assim, a mudança de fluxo produziu uma espécie de "seleção natural" dentro do RALF, arrastando boa parcela da biomassa suspensa, da biomassa presente nos interstícios das biopartículas, e também da parcela de biomassa que não foi devidamente imobilizada nos suportes.

\subsubsection{DESCRIÇÃO DAS FASES OPERACIONAIS}

A Tabela 5.12 mostra um quadro resumo com as fases de operação do reator A antes da colocação do PCP no sistema.

Tabela 5.12 - Fases e parâmetros operacionais do RALF A utilizado na pesquisa, sem a adição de PCP.

\begin{tabular}{ccccccccc}
\hline FASE & Dias & $\begin{array}{c}\mathbf{d}_{\mathbf{p}} \\
(\mathbf{m m})\end{array}$ & $\begin{array}{c}\text { vazão } \\
(\mathbf{L} / \mathrm{dia})\end{array}$ & $\begin{array}{c}\boldsymbol{\theta}_{\mathbf{h}} \\
(\text { horas })\end{array}$ & $\begin{array}{c}\text { DQO } \\
(\mathbf{m g} / \mathbf{L})\end{array}$ & $\begin{array}{c}\text { C.O } \\
(\mathbf{g} \text { DQO/dia) }\end{array}$ & $\begin{array}{c}\text { T.C.O } \\
(\mathbf{g ~ D Q O} / \mathbf{L} . d i a)\end{array}$ & $\begin{array}{c}\text { altura leito } \\
\text { estático }(\mathbf{c m})\end{array}$ \\
\hline I & $0-7$ & 3,08 & 30 & 13 & 500 & 15 & 0,9 & 40 \\
II & $8-54$ & 3,08 & 30 & 13 & 1000 & 30 & 1,9 & 40 \\
III & $55-70$ & 3,08 & 30 & 13 & 500 & 15 & 0,9 & 60 \\
IV & $71-89$ & 3,08 & 48 & 8,0 & 500 & 24 & 1,5 & 60 \\
V & $90-108$ & 3,08 & 48 & 8,0 & 1000 & 48 & 3,0 & 60 \\
\hline \multicolumn{7}{c}{ Obs. $\left.{ }^{*}\right) d_{p}$ : diâmetro médio de peneira das partículas de carvão ativado. }
\end{tabular}

É importante salientar que os parâmetros operacionais de cada fase foram atribuídos exclusivamente de acordo com as respostas dadas pelo próprio reator. Ou seja, com exceção de que existia uma programação previamente estabelecida de se iniciar a operação com uma DQO de aproximadamente $500 \mathrm{mg} / \mathrm{L}$ e se chegar a uma DQO de entrada de aproximadamente $1000 \mathrm{mg} / \mathrm{L}$, além da manutenção da taxa de expansão do leito em $35 \%$, não houve qualquer premeditação quanto à duração e os parâmetros de cada fase. Os critérios estabelecidos para a mudança dos parâmetros operacionais serão relatados na medida em que os resultados de desempenho forem apresentados. Para facilitar a comparação, os resultados obtidos nas análises de microscopia sem o PCP são apresentados conjuntamente com os resultados obtidos com o PCP, no item 5.5.2. 


\subsubsection{VARIAÇÃO DOS PARÂMETROS DE MONITORAMENTO DO RALF A}

Os dados obtidos para desempenho do reator, em termos de concentração de DQO $\left(S_{b}\right)$ no afluente e no efluente e eficiência de remoção de DQO ( $\left.E_{D Q O}\right)$ são apresentados respectivamente nas Figuras 5.31 e 5.32.

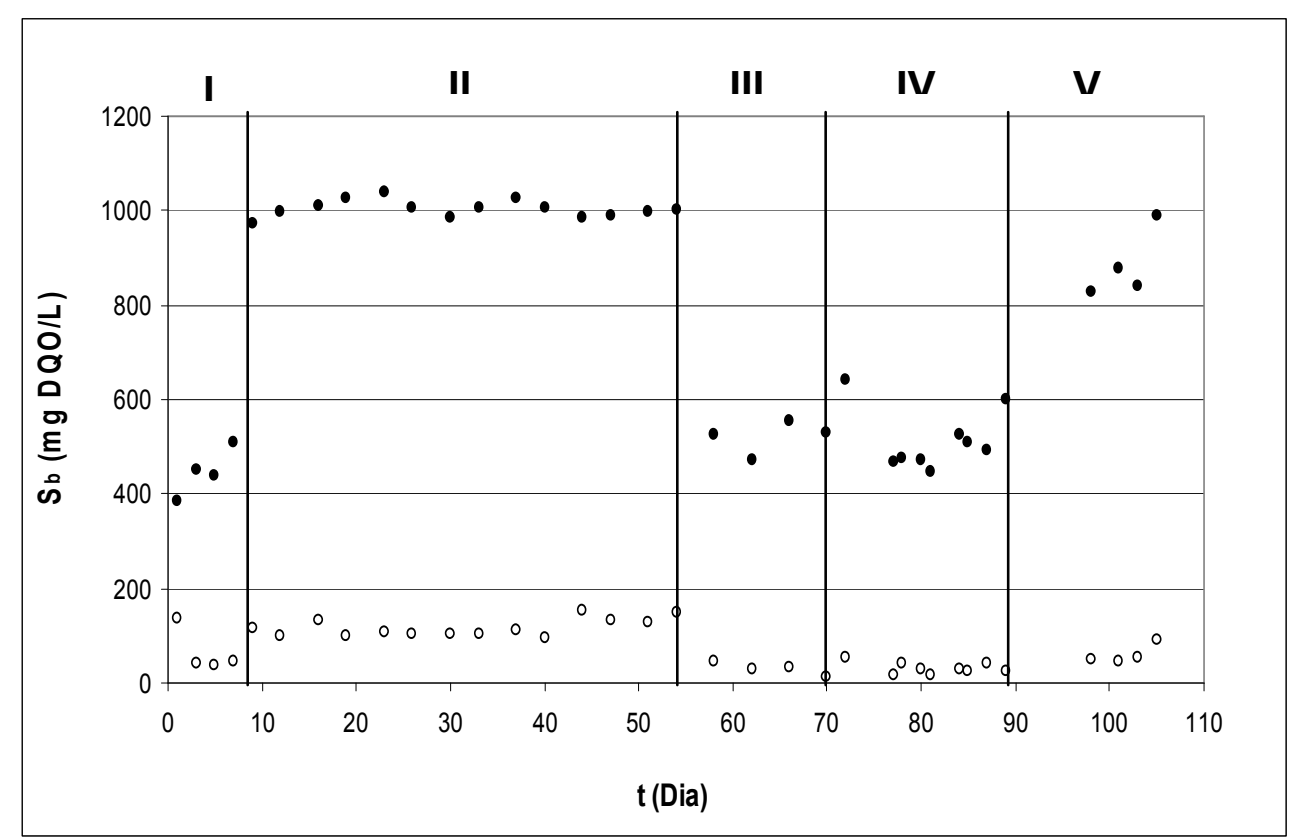

Figura 5.31 - Variação temporal da concentração expressa como DQO para as $\mathbf{5}$ fases do RALF tratando efluente sintético.

(•) DQO afluente (o) DQO efluente.

$\mathrm{Na}$ análise das Figuras 5.31 e 5.32 observa-se que a partida do RALF foi extremamente rápida, confirmando uma das características de reatores anaeróbios quando submetidos a processos de inoculação. O RALF foi submetido a uma DQO de entrada de aproximadamente $400 \mathrm{mg} / \mathrm{L}$ e já no primeiro dia após a partida, a eficiência de remoção em termos de DQO foi de $64 \%$, subindo para mais de $90 \%$ a partir do terceiro dia. Os resultados do primeiro dia foram descartados em todos os cálculos estatísticos. 


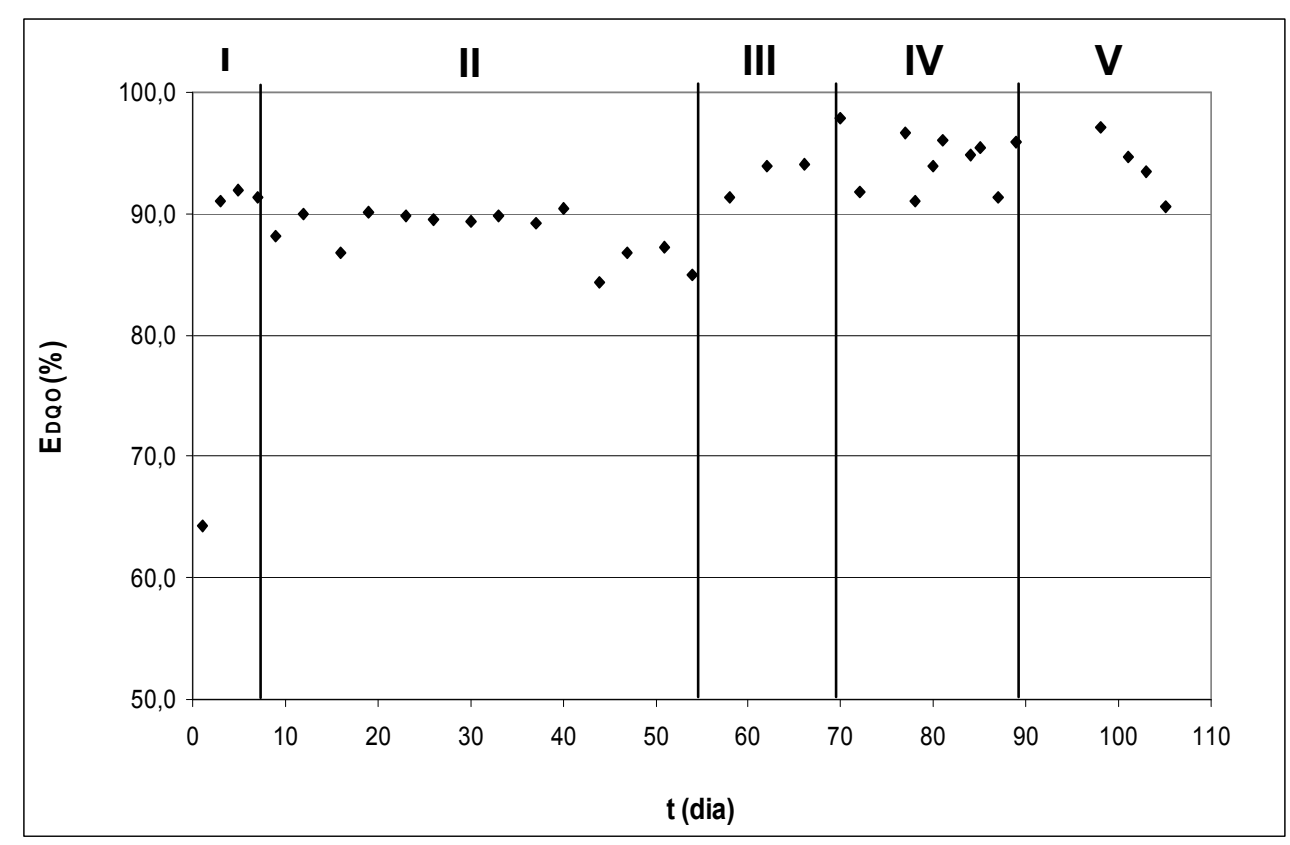

Figura 5.32 - Variação temporal da eficiência de remoção de DQO no RALF A tratando efluente sintético.

Isso indica o grande potencial de adaptação do lodo de inóculo, e também que provavelmente o processo de inoculação por "circuito fechado" e a etapa de transição, com o reator trabalhando como leito fixo, foram benéficos para a eficiência dessa partida. Descontando-se o primeiro dia com o RALF ainda sob efeito de adaptação às novas condições, a fase I teve remoção média de DQO de $(91,4 \pm 0,5) \%$.

As Tabelas 5.13 e 5.14 mostram, respectivamente, para cada fase, alguns parâmetros estatísticos (média, desvio padrão, valor máximo e valor mínimo) obtidos para as concentrações de DQO (afluente e efluente) e para a eficiência de remoção de DQO.

Tabela 5.13 - Parâmetros estatísticos obtidos para as concentrações de DQO (afluente e efluente) nas 5 fases.

\begin{tabular}{c|cccc|cccc}
\hline \multirow{2}{*}{ FASE } & \multicolumn{3}{|c|}{ DQO afluente (mg/L) } & \multicolumn{3}{c}{ DQO efluente (mg/L) } \\
\cline { 2 - 9 } & média & DP & máximo & mínimo & média & DP & máximo & mínimo \\
\hline I & 466,1 & 37,9 & 509,4 & 438,7 & 40,1 & 4,5 & 44,4 & 35,4 \\
II & 1002,9 & 17,5 & 1037,3 & 973,0 & 117,2 & 19,1 & 153,6 & 97,1 \\
III & 520,9 & 33,7 & 553,0 & 473,4 & 29,6 & 14,3 & 45,7 & 11,0 \\
IV & 513,7 & 65,3 & 640,6 & 445,1 & 30,4 & 12,6 & 52,5 & 15,9 \\
V & 883,1 & 73,7 & 989,2 & 826,3 & 60,7 & 21,9 & 93,1 & 46,2 \\
\hline
\end{tabular}


Tabela 5.14 - Parâmetros estatísticos obtidos para as eficiências de remoção de DQO nas 5 fases.

\begin{tabular}{c|cccc}
\hline \multirow{2}{*}{ FASE } & \multicolumn{4}{|c}{$\mathbf{E}_{\text {DQO }}$ (\%) } \\
\cline { 2 - 5 } & média & DP & máximo & mínimo \\
\hline I & 91,4 & 0,5 & 91,9 & 91,0 \\
II & 88,3 & 2,0 & 90,4 & 84,4 \\
III & 94,3 & 2,7 & 97,9 & 91,3 \\
IV & 94,1 & 2,2 & 96,6 & 91,0 \\
V & 93,2 & 1,8 & 94,7 & 90,6 \\
\hline
\end{tabular}

Em virtude dessa capacidade de resposta rápida, avaliou-se que, para a otimização do trabalho, não seria necessário aumentar a DQO em pequenos incrementos. Dessa maneira, para não se perder tempo, iniciou-se a fase II e o RALF foi então submetido à concentração de DQO programada para toda a continuidade da pesquisa, ou seja, $1000 \mathrm{mg} / \mathrm{L}$.

$\mathrm{Na}$ fase II, com aumento da DQO afluente, a remoção média de DQO caiu para $(88,3 \pm 2,0) \%$, mostrando que houve uma pequena queda de rendimento com o aumento da carga orgânica. Mesmo com essa ligeira queda na eficiência de remoção em termos de DQO o comportamento do reator foi considerado satisfatório.

Um problema associado a esse aumento da carga orgânica, entretanto, foi verificado nesta fase. Após a introdução da DQO de aproximadamente 1000 $\mathrm{mg} / \mathrm{L}$, iniciou-se um processo gradativo de formação de biofilme nas paredes do tubo de vidro do reator, de baixo para cima, a ponto de o tubo ficar completamente negro por volta do $40^{\circ}$ dia de operação, mostrando claramente que a formação de biomassa imobilizada estava maior do que a capacidade do sistema em absorver essa síntese. Imagens desse problema foram registradas mas não apresentaram uma boa qualidade. $O$ reator $B$ apresentou um comportamento semelhante, porém em menor intensidade. A Figura 5.33 mostra o reator $B$ com o mesmo problema de adesão de biomassa nas paredes apresentado pelo reator $\mathrm{A}$. 


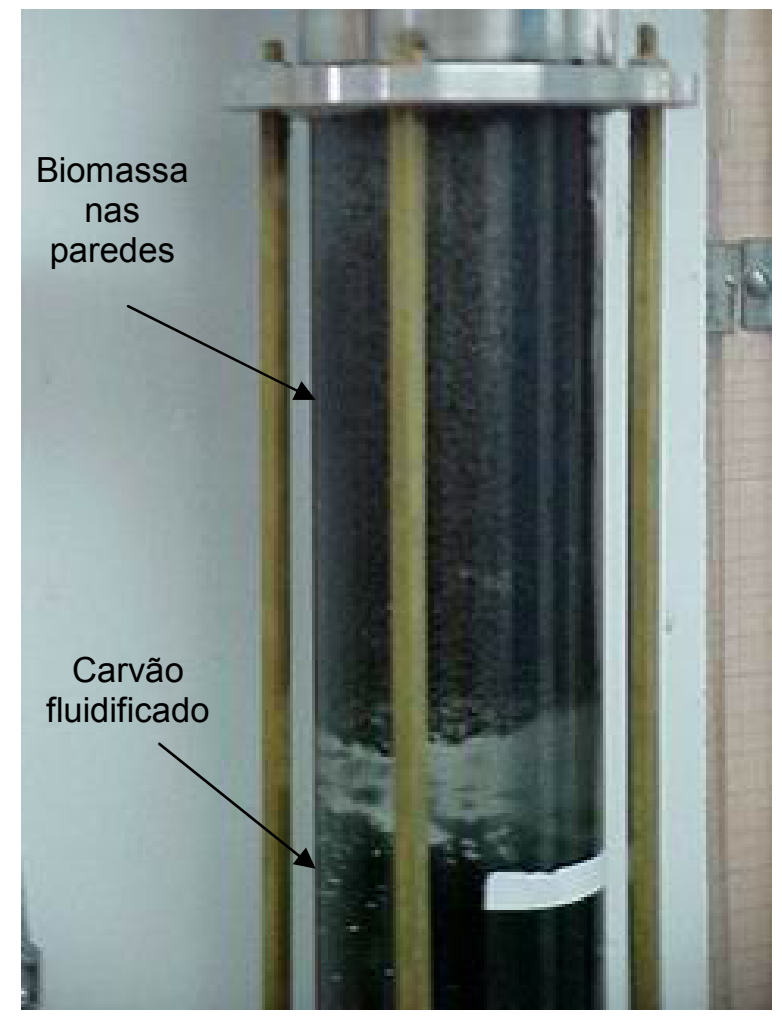

Figura 5.33 - Reator B apresentando imobilização de biomassa nas paredes.

A partir desse momento, 3 procedimentos foram cogitados. A primeira opção seria não fazer qualquer alteração e começar a introduzir o PCP no sistema. Essa opção foi logo descartada em virtude da situação estar até certo ponto perigosa, pois não era possível enxergar a qualidade da fluidificação, e nem se a expansão do leito estava alcançando (ou ultrapassando) a altura previamente estipulada. Basicamente essa opção se direcionava contra os critérios de concepção do reator, já que se escolheu um tubo de vidro para a parte reacional justamente para se obter uma boa visualização de seu comportamento.

Além disso, naquele momento, a inclusão do PCP foi considerada inapropriada pelo fato do sistema experimental ainda não estar totalmente completo. Como foi descrito na metodologia, para proporcionar um monitoramento mais qualificado da variação de temperatura foram adquiridos e instalados alguns equipamentos. Entretanto, no momento em que se cogitavam soluções para este problema de formação de biofilme, esses equipamentos ainda não haviam sido entregues pelo fornecedor. Decidiu-se, dessa maneira, 
que o PCP só seria introduzido a partir do momento em que todo o sistema experimental estivesse completo.

Uma alternativa cogitada foi alterar o volume de reação do RALF. Isso poderia ser feito basicamente de duas maneiras: aumentar a taxa de recirculação, e conseqüentemente a expansão do leito, ou acrescentar uma quantidade de carvão ativado (inerte) dentro do reator, aumentando assim a altura estática do leito, mantendo a mesma expansão. As duas opções aumentariam de diferentes maneiras o volume reativo.

Como a recirculação pode ser comparada a um processo de "looping", o aumento de sua taxa faz com que a fase líquida passe por mais vezes em contato com as biopartículas (fase sólida). Por outro lado, serão aplicadas maiores vazões de recirculação, com maiores diferenças de pressão no leito, e maior possibilidade de cisalhamento do biofilme formado. O aumento da altura estática do leito, através da introdução de carvão ativado, possibilita um acréscimo de área para a adesão de biomassa e também aumenta os efeitos físicos de adsorção. Optou-se por aumentar a altura estática do leito, passando de $40 \mathrm{~cm}$ (1/3 da altura do tubo) para $60 \mathrm{~cm}$ (1/2 da altura do tubo), mantendo a mesma taxa de expansão (35\%). A operação do reator como leito fluidificado foi provisoriamente interrompida para a realização de um novo (e rápido) processo de inoculação, para a adesão de biomassa no carvão que foi adicionado ao RALF. O tempo gasto com essa nova inoculação (7 dias) foi suprimido da Tabela 5.12. Com a finalidade de verificar se a alteração da altura estática do leito provocaria alguma diferença no desempenho do RALF, a DQO de entrada foi reduzida para $500 \mathrm{mg} / \mathrm{L}$, iniciando-se então a fase III de operação. A média de remoção desta fase foi de $(94,3 \pm 2,7) \%$. Comparandose com a fase I, é possível verificar que o processo de mudança escolhido foi um fator determinante para a melhora do desempenho do RALF e também resolveu o problema de imobilização de biomassa nas paredes.

As conseqüências do aumento da vazão e da DQO afluentes no desempenho de um RALF já foram bem estudadas na literatura, porém, os efeitos da variação do volume de reação, relacionado com a quantidade de material suporte ou com a expansão do leito ainda necessitam de maiores investigações. Em um RALF, para uma mesma altura final de leito existem diversas combinações possíveis de altura estática e expansão. O processo de 
otimização dos reatores passa obrigatoriamente pelo estudo dessas combinações. Na prática, os pesquisadores fixam tanto a quantidade de material suporte, quanto os valores de expansão do leito (normalmente na faixa de $25 \%$ a $35 \%$ ). É necessário que vários pares desses parâmetros sejam testados para verificar a combinação "ótima".

Até então o sistema ainda não havia sido submetido a uma variação na carga hidráulica. Dessa maneira, a fase IV teve início quando a vazão de alimentação foi aumentada (de 30 para 48 L/dia), ocasionando uma diminuição do tempo de detenção hidráulica de 13 para 8 horas. A eficiência média de remoção de DQO para esta fase foi de $(94,1 \pm 2,2) \%$. No $72^{\circ}$ dia de operação, a bomba de recirculação começou a apresentar problemas. Assim, a bomba centrífuga da marca MARK, modelo XD2, com motor de $1 / 2 \mathrm{CV}$ foi desligada, retirada do sistema, e no mesmo dia foi providenciada uma outra bomba, marca THEBE, modelo TA - 13, para substituir a bomba danificada. $O$ processo de substituição foi rápido e não provocou mudanças de comportamento no reator, como foi verificado nas análises posteriores.

Finalmente para se chegar às condições previstas, a DQO de entrada foi aumentada para $1000 \mathrm{mg} / \mathrm{L}$. Nesta fase (fase V), obteve-se uma eficiência média de remoção de $(93,2 \pm 1,8) \%$. Comparando-se as fases II e V (Tabela 5.14) é possível notar que o acréscimo de carvão ativado no leito aumentou consideravelmente a eficiência de remoção de matéria orgânica, mesmo com a diminuição do tempo de detenção hidráulica. Nesta fase também ocorreu adesão de biomassa nas paredes do leito, entretanto em escala muito menor do que a ocorrida na fase II.

Alguns pontos "suspeitos" durante essa fase de operação do reator sem o PCP foram descartados no tratamento dos dados e na apresentação dos resultados. Por causas desconhecidas, algumas vezes a bomba de alimentação apresentou uma deficiência de não bombear o afluente para dentro do reator. Suspeita-se que esse problema foi ocasionado por pequenas bolhas de ar no reservatório afluente, decorrentes da agitação (manual) que era feita para homogeneizar o volume líquido. Essas bolhas entravam na mangueira de sucção e impediam o funcionamento correto da bomba, fazendo com que a alimentação do reator fosse interrompida temporariamente, ou totalmente. Em algumas ocasiões, passado um intervalo de tempo, a própria 
seqüência de pulsos dada pela bomba era capaz de expulsar as bolhas de ar e o problema se resolvia sozinho. Entretanto ocorria uma alteração do tempo de detenção hidráulica estipulado. Em outras oportunidades, este problema foi notado e solucionado um ou dois dias depois de sua ocorrência. Assim, na fase II, por exemplo, foi obtido um ponto com remoção de DQO de 96\%, bem diferente da média encontrada no período, que foi de 88,3\%. Esses pontos foram descartados por não representarem as condições operacionais estipuladas para o reator em determinada fase. É conveniente salientar, entretanto, que esse fenômeno de interrupção de bombeamento com modificações consideráveis no TDH ocorreu apenas por 5 vezes em todos os 105 dias de operação do reator sem PCP.

A Figura 5.34 mostra os valores encontrados para a alcalinidade total $\left(A_{T}\right)$ do sistema e a Tabela 5.15 apresenta um resumo com alguns parâmetros estatísticos (média, desvio padrão, valor máximo e valor mínimo) obtidos para a alcalinidade total (afluente e efluente).

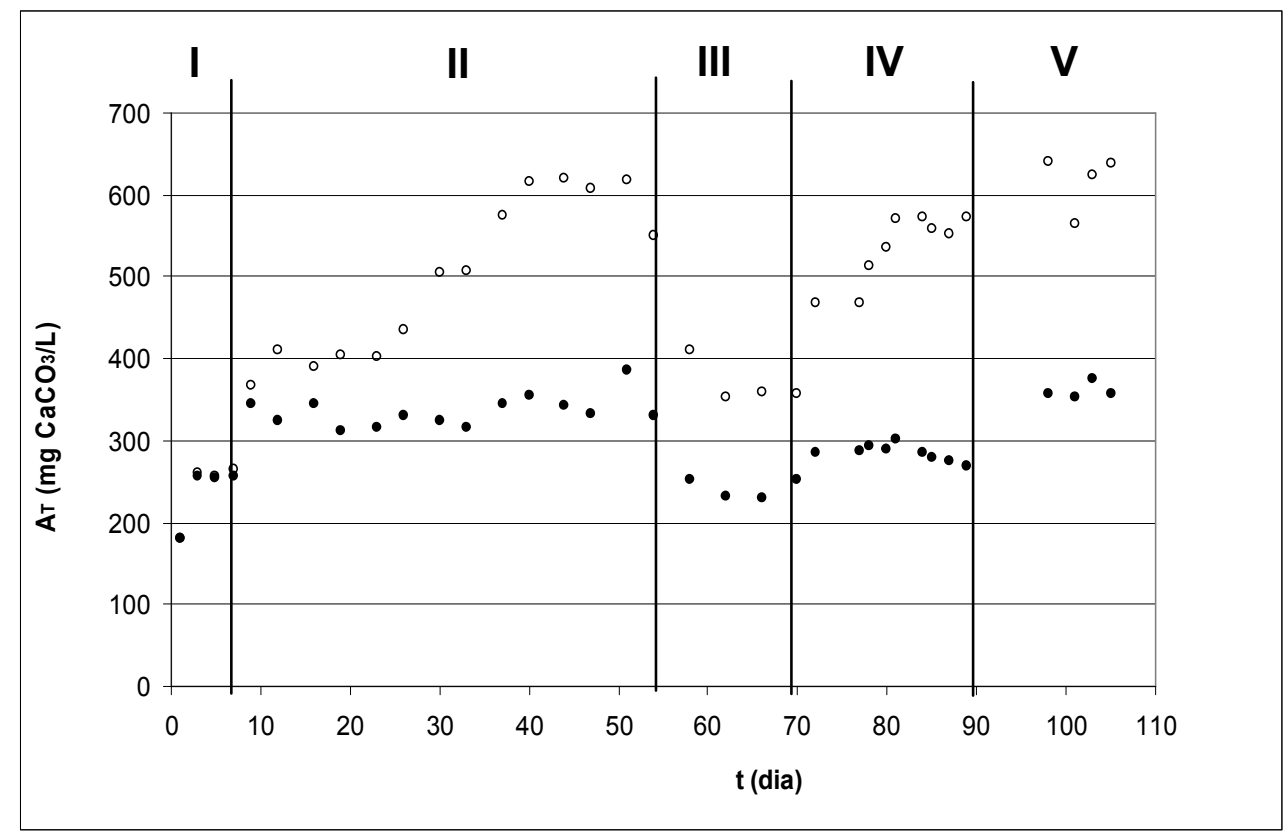

Figura 5.34 - Variação temporal da concentração de alcalinidade total $\left(A_{T}\right)$ do RALF A tratando efluente sintético. (•) $A_{T}$ afluente e (o) $A_{T}$ efluente.

A alta estabilidade operacional observada no RALF nesse período sem PCP foi confirmada pela avaliação desses parâmetros. A geração de alcalinidade ao longo do processo anaeróbio é um bom indício de estabilidade. 
Os valores no efluente maiores que no afluente representam que a remoção de ácidos voláteis do sistema foi efetiva.

Em reatores biológicos, o acúmulo de ácidos orgânicos voláteis indica um desbalanceamento entre as velocidades de consumo de matéria orgânica, realizado pelos diferentes tipos de bactérias. A "harmonia" entre esse consumo de matéria orgânica, por sinal, é responsável pelo desempenho adequado do sistema de tratamento anaeróbio. Quando a concentração de ácidos voláteis se torna muito elevada, ou melhor, quando não existe mais efeito tampão devido à ausência de alcalinidade a bicarbonato, há probabilidade de ocorrência de problemas graves com o sistema de tratamento, devido à diminuição do $\mathrm{pH}^{17}$.

Tabela 5.15 - Parâmetros estatísticos obtidos para a alcalinidade total (afluente e efluente) nas $\mathbf{5}$ fases.

\begin{tabular}{c|cccc|cccc}
\hline \multirow{2}{*}{ FASE } & \multicolumn{4}{|c|}{ Alcalinidade total afluente (mg/L) } & \multicolumn{4}{c}{ Alcalinidade total efluente (mg/L) } \\
\cline { 2 - 8 } & média & DP & máximo & mínimo & média & DP & máximo & mínimo \\
\hline I & 256,6 & 1,2 & 257,3 & 255,2 & 260,7 & 4,6 & 265,5 & 256,2 \\
II & 336,6 & 19,2 & 385,9 & 311,8 & 500,4 & 96,6 & 619,5 & 368,4 \\
III & 241,6 & 12,2 & 252,1 & 229,5 & 370,2 & 26,4 & 409,5 & 352,9 \\
IV & 285,0 & 10,1 & 302,5 & 268,6 & 534,5 & 42,7 & 573,3 & 467,2 \\
V & 361,4 & 10,3 & 376,6 & 354,0 & 617,1 & 35,5 & 640,0 & 564,9 \\
\hline
\end{tabular}

A geração de alcalinidade também é verificada analisando-se os valores de $\mathrm{pH}$. A Figura 5.35 mostra os valores obtidos no monitoramento do $\mathrm{pH}$ afluente e efluente.

\footnotetext{
${ }^{17}$ Informação contida no roteiro de laboratório (LPB) para a execução de ensaios de alcalinidade.
} 


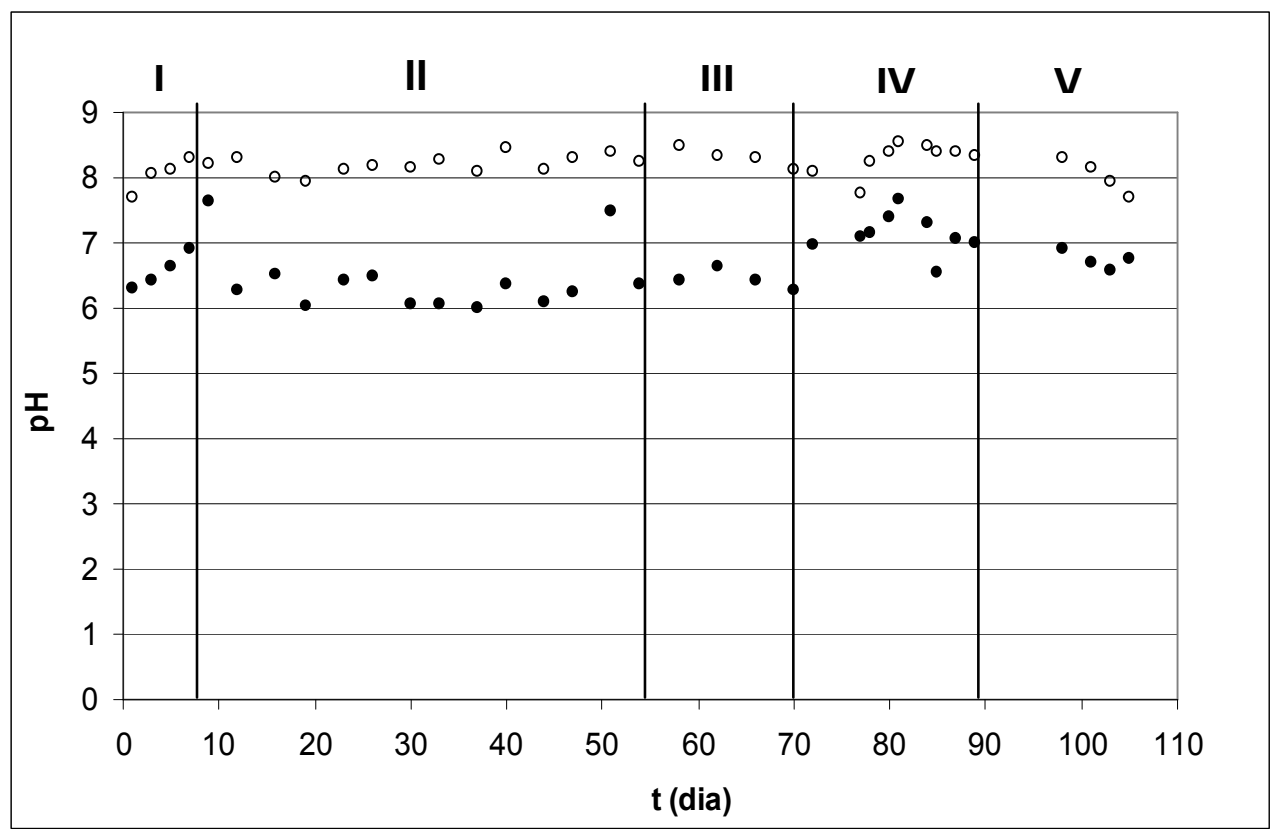

Figura 5.35 - Variação temporal dos valores de pH no RALF A tratando efluente sintético. (•) pH afluente (o) pH efluente.

A Tabela 5.16 apresenta um resumo com alguns parâmetros estatísticos (média, desvio padrão, valor máximo e valor mínimo) obtidos para $\circ \mathrm{pH}$ (afluente e efluente) nas cinco fases.

Tabela 5.16 - Parâmetros estatísticos obtidos para o pH (afluente e efluente) nas 5 fases.

\begin{tabular}{c|cccc|cccc}
\hline \multirow{2}{*}{ FASE } & \multicolumn{4}{|c|}{ pH Afluente } & \multicolumn{4}{c}{ pH Efluente } \\
\cline { 2 - 8 } & média & DP & máximo & mínimo & média & DP & máximo & Mínimo \\
\hline I & 6,57 & 0,27 & 6,92 & 6,30 & 8,05 & 0,23 & 8,30 & 7,71 \\
II & 6,43 & 0,51 & 7,64 & 6,00 & 8,20 & 0,14 & 8,45 & 7,94 \\
III & 6,44 & 0,15 & 6,64 & 6,28 & 8,32 & 0,15 & 8,50 & 8,13 \\
IV & 7,13 & 0,31 & 7,66 & 6,55 & 8,29 & 0,24 & 8,55 & 7,75 \\
V & 6,73 & 0,14 & 6,90 & 6,57 & 8,03 & 0,26 & 8,31 & 7,70 \\
\hline
\end{tabular}

Nota-se que a alcalinidade total e o $\mathrm{pH}$ do efluente foram, na maior parte do experimento, maiores do que no afluente, uma característica usual de reatores anaeróbios quando operam de maneira estável. O aumento da carga orgânica na entrada proporcionou um aumento na alcalinidade efluente. $\mathrm{Na}$ fase II, por exemplo, é possível perceber que a alcalinidade efluente foi gradativamente aumentando com o tempo de operação do reator, indicando um processo de estabilização mais lento que o de remoção de matéria orgânica. 
No que diz respeito às variações da alcalinidade, uma explicação geral torna-se necessária, e pode ser estendida a todos os outros parâmetros. Os processos anaeróbios envolvem uma complexa seqüência de reações, com muitas variáveis envolvidas e, dessa maneira, já não é esperada a mesma reprodutibilidade que é obtida em ensaios físicos, como os fluidodinâmicos, por exemplo. Além disso, outros fatores, dentre os quais as variações na vazão de alimentação, na vazão de recirculação, na composição do efluente sintético, nas características das biopartículas, além dos próprios erros dos métodos de análise, também irão influenciar nos resultados e provocar maiores desvios nos parâmetros.

Algumas medidas de $\mathrm{pH}$ afluente mais elevadas, encontradas na Figura 5.35, foram realizadas no mesmo dia de preparação do efluente. Um dia após o preparo, o valor do $\mathrm{pH}$ do afluente sofria uma pequena queda. Como o efluente não sofria qualquer procedimento especial de preservação e apenas ficava armazenado no reservatório fechado, essa queda indicou um provável processo de acidificação da glicose no afluente. Um teste foi feito medindo-se diariamente $\mathrm{o} \mathrm{pH}$ de uma parcela do efluente, deixada exclusivamente para essa finalidade, e verificou-se que essa queda no $\mathrm{pH}$, decorrente de reações de acidificação, ocorria quase integralmente nas primeiras 24 hs e depois se estabilizava, talvez pelo efeito "tampão" no efluente, causado pela presença de bicarbonato de sódio.

Pelo comportamento usual encontrado nos parâmetros de monitoramento do reator, além do elevado desempenho na remoção de matéria orgânica, esse fenômeno aparentemente não proporcionou conseqüências negativas ao processo. Pelo contrário, como já foi relatado na revisão da literatura deste trabalho, muitos autores utilizaram em suas pesquisas ácidos voláteis como fontes de carbono para elaboração do efluente afluente de seus respectivos reatores tratando PCP (DAMIANOVIC, 1997; LARIZZATTI, 1997; OLIVEIRA, 1998; BARALDI, 2001). Dessa maneira, considerou-se que a produção espontânea de alguns ácidos voláteis no afluente poderia até ser benéfica ao sistema. De acordo com os resultados obtidos, que mostram um desempenho satisfatório do RALF, nota-se que a presença dos ácidos voláteis não causaram efeitos adversos às taxas de consumo de substrato. 
Como se observou, os parâmetros de monitoramento mostram que houve geração de alcalinidade com consumo de ácidos voláteis. Ainda com relação aos ácidos voláteis, percebeu-se que particularmente nessa pesquisa o método potenciométrico não foi adequado para a determinação da concentração $\left(\mathrm{C}_{\mathrm{AVT}}\right)$ efluente, apesar da boa similaridade entre os dados obtidos. Uma breve explicação do método se torna necessária antes da explicação de sua inadequação.

Resumidamente, a técnica consiste em abaixar o pH da amostra, que geralmente é a mesma amostra que foi utilizada nos ensaios de alcalinidade, até um valor menor que 3 , com solução padronizada de $\mathrm{H}_{2} \mathrm{SO}_{4}$. Pérolas de vidro são então adicionadas à amostra para aquecimento em chapa elétrica. Após uma fervura de 3 minutos, que remove o gás carbônico remanescente da solução, a amostra deve ser resfriada até a temperatura ambiente. Feito isso, deve-se corrigir $\mathrm{opH}$ da amostra até 4 , com solução de $\mathrm{NaOH}$ e adicionar solução de $\mathrm{NaOH}$ para elevar o $\mathrm{pH}$ da amostra de 4 até 7 , anotando o volume gasto de $\mathrm{NaOH}$. A Figura 5.36 mostra os valores encontrados para a concentração de ácidos voláteis $\left(\mathrm{C}_{\mathrm{AVT}}\right)$ para os primeiros 26 dias de operação, ou seja, quando a metodologia de análise utilizada foi 0 método potenciométrico.

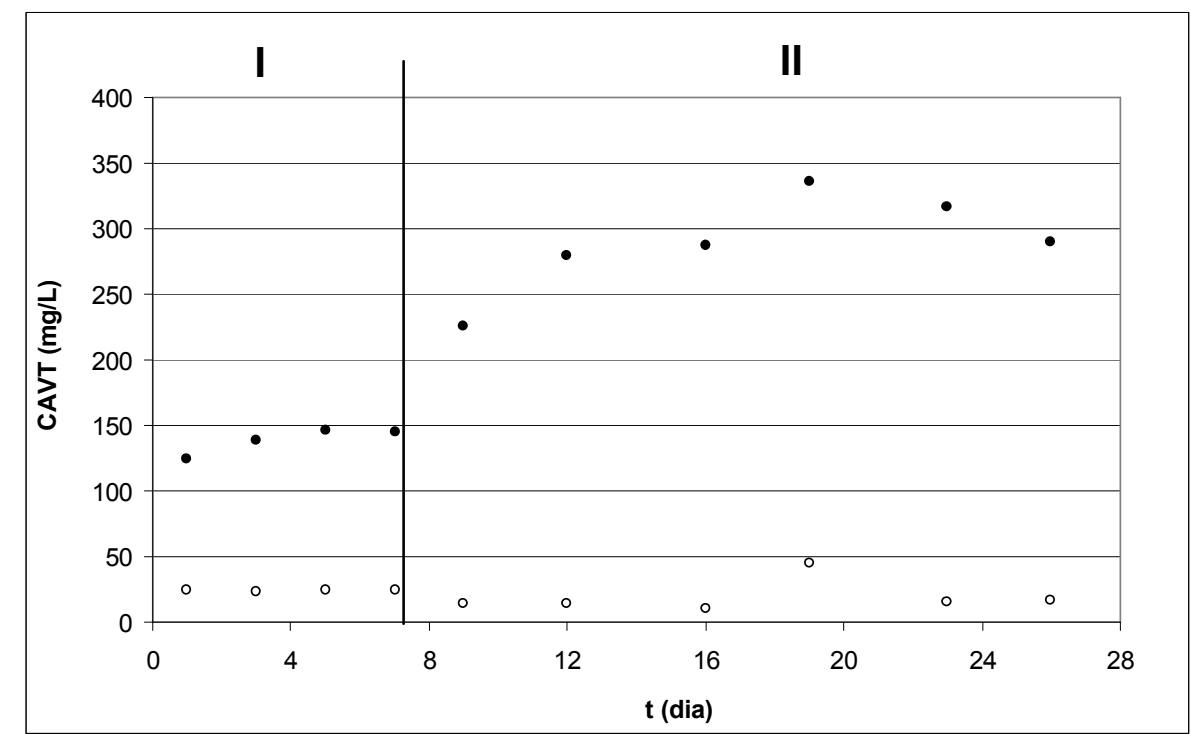

Figura 5.36 - Variação temporal da concentração de AVT ( $\left.\mathrm{C}_{\mathrm{AVT}}\right)$ do RALF tratando efluente sintético para os primeiros 26 dias de operação.

(•) $C_{A V T}$ afluente e (o) $C_{A V T}$ efluente 
Um problema verificado nessa etapa foi que apenas algumas gotas de $\mathrm{NaOH}$ já foram suficientes para elevar rapidamente $\mathrm{opH}$ das amostras analisadas para valores maiores que 7 (geralmente até maiores que 8). Dessa maneira, quase nunca foi possível determinar o volume exato gasto nessa elevação de $\mathrm{pH}$. O que se fez foi uma estimativa aproximada. Isso mostra que a concentração de ácidos voláteis no efluente foi muito pequena e que o método utilizado inicialmente não foi o mais apropriado. Porém, esse fato não poderia ter sido previsto, já que foi confirmado durante a etapa experimental.

Para solucionar esse problema, foram analisadas duas alternativas. A primeira, fazer uma diluição da solução de $\mathrm{NaOH}$, e a segunda, mudar o método de análise para cromatografia gasosa (CG). Essa segunda opção tem a vantagem de quantificar isoladamente cada ácido de uma determinada amostra (acético, propiônico, butírico, dentre outros) e apresentar nos resultados as concentrações isoladas de cada um.

Portanto, a partir do $27^{\circ}$ dia de operação do reator, os valores de $\mathrm{C}_{\mathrm{AVT}}$ foram determinados por cromatografia gasosa, método desenvolvido pelo próprio LPB (Moraes et al., 2000). As amostras foram conservadas para posterior injeção dentro do cromatógrafo. A conservação consistiu em congelar as amostras com uma gota de solução concentrada de $\mathrm{NaOH}$.

A Figura 5.37 mostra os resultados obtidos para a concentração total de ácidos voláteis, pelo método de cromatografia, para o restante do tempo de operação do RALF (do dia 27 ao dia 105). 


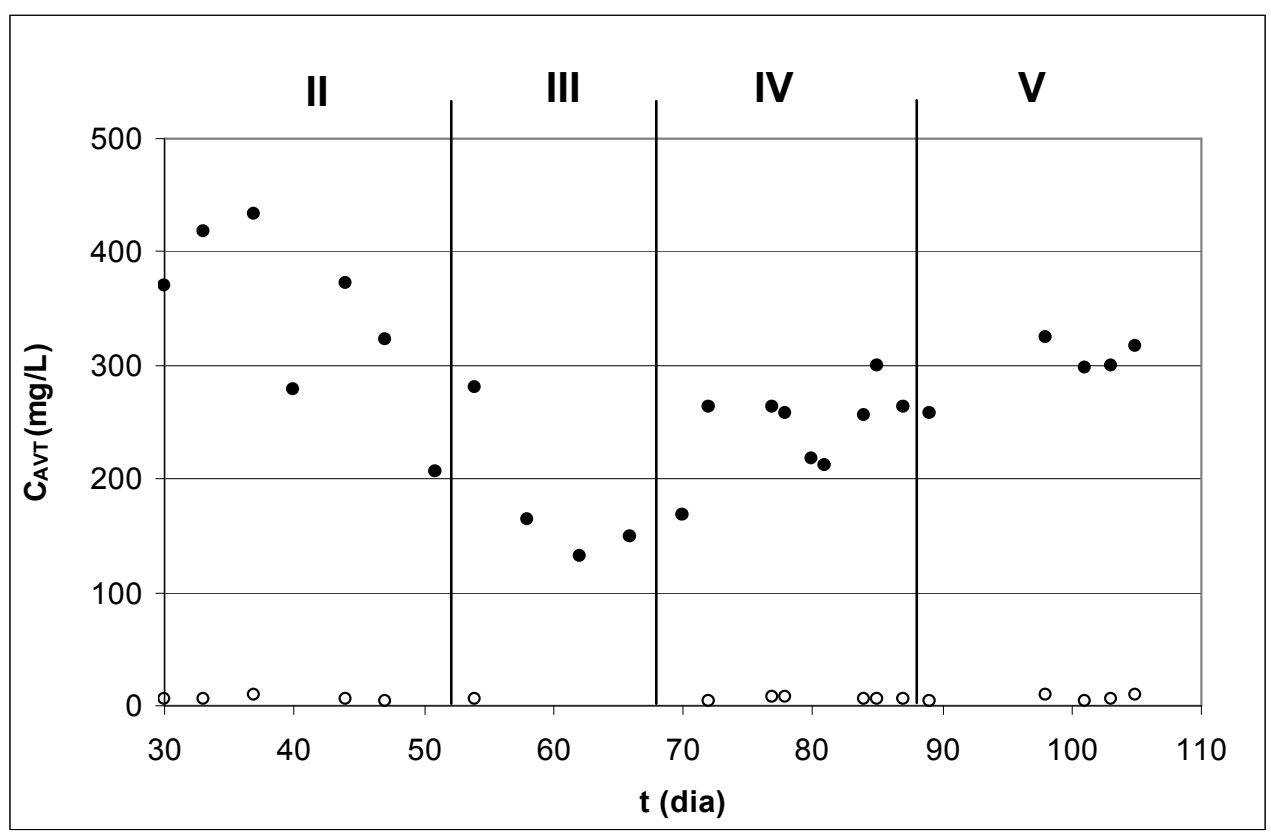

Figura 5.37 - Variação temporal da concentração de AVT ( $\left.C_{A V T}\right)$ do RALF A tratando efluente sintético para os outros dias de operação (do dia 26 ao dia 105).

\section{(•) $C_{A V T}$ afluente $e(0) C_{A V T}$ efluente}

Em geral os valores das concentrações totais de ácidos voláteis no afluente acompanharam os valores de carga orgânica aplicados, e também os de $\mathrm{pH}$ afluente, o que de certa forma era esperado. Como já foi explicado na discussão dos valores de $\mathrm{pH}$, o processo de acidificação da glicose no efluente interferiu para uma maior variação nos valores de entrada, além do fato de que a grande quantidade de afluente que era preparada ocasionava diferenças em sua composição. Quando as análises foram realizadas no dia de preparação do substrato, em geral foram obtidos valores maiores de $\mathrm{pH}$ e menores concentrações de ácidos voláteis.

As maiores concentrações de glicose no afluente permitiram também que ocorresse um maior processo de acidificação, resultando em maiores concentrações de ácidos voláteis. Quando a DQO de entrada foi novamente reduzida para a faixa de $500 \mathrm{mg} / \mathrm{L}$, os ácidos voláteis no afluente sofreram um considerável declínio, e depois voltaram a aumentar com o aumento da DQO.

Nota-se pela análise das Figuras 5.36 e 5.37 que o segundo método foi muito mais sensível que o primeiro, apresentando, além de uma maior variação, valores maiores de concentração de ácidos voláteis. Em virtude da 
concentração de ácidos voláteis ter sido determinada através de dois métodos diferentes, e também da diferença de valores encontrada pelos métodos, optou-se por fazer um tratamento estatístico apenas para os dados de ácidos voláteis obtidos pelo segundo método. A Tabela 5.17 apresenta um resumo com alguns parâmetros estatísticos (média, desvio padrão, valor máximo e valor mínimo) obtidos para a concentração de ácidos voláteis (afluente e efluente) nas fases em que o método de cromatografia gasosa foi utilizado.

Tabela 5.17 - Parâmetros estatísticos obtidos para a concentração de ácidos voláteis (afluente e efluente) em cada uma das fases.

\begin{tabular}{c|cccc|cccc}
\hline \multirow{2}{*}{ FASE } & \multicolumn{4}{|c|}{$\mathbf{C}_{\text {AVT }}$ Afluente (mg/L) } & \multicolumn{3}{c}{$\mathbf{C}_{\text {AVT }}$ Efluente (mg/L) } \\
\cline { 2 - 8 } & média & DP & máximo & mínimo & média & DP & máximo & Mínimo \\
\hline II & 335,3 & 77,4 & 432,74 & 206,52 & 6,0 & 1,8 & 9,5 & 4,5 \\
III & 153,4 & 16,5 & 168,6 & 131,8 & ND $^{*}$ & ND & ND & ND \\
IV & 254,5 & 26,2 & 300,16 & 211,4 & 6,0 & 1,2 & 7,5 & 4,2 \\
V & 309,5 & 13,3 & 324,0 & 296,8 & 7,0 & 2,3 & 9,0 & 4,2 \\
\hline
\end{tabular}

Obs.: ( $\left.{ }^{*}\right)$ na fase III não foram detectados ácidos voláteis no efluente.

No efluente, o ácido acético foi encontrado como forma única de ácido volátil. A concentração de ácidos voláteis foi extremamente baixa, como pode ser verificado na Figura 5.37. O valor máximo encontrado foi de 9,46 mg/L, sendo que em várias oportunidades, como por exemplo do dia 58 ao dia 70 (fase III), as concentrações de ácidos voláteis no efluente nem foram detectadas pelo método. Essa característica reforça toda a dificuldade encontrada empregando-se o método potenciométrico na quantificação da concentração de ácidos voláteis do efluente. Dessa maneira, conclui-se que a troca de métodos foi apropriada. A Figura 5.38 mostra as concentrações afluentes isoladas de cada ácido volátil encontrado no afluente. 


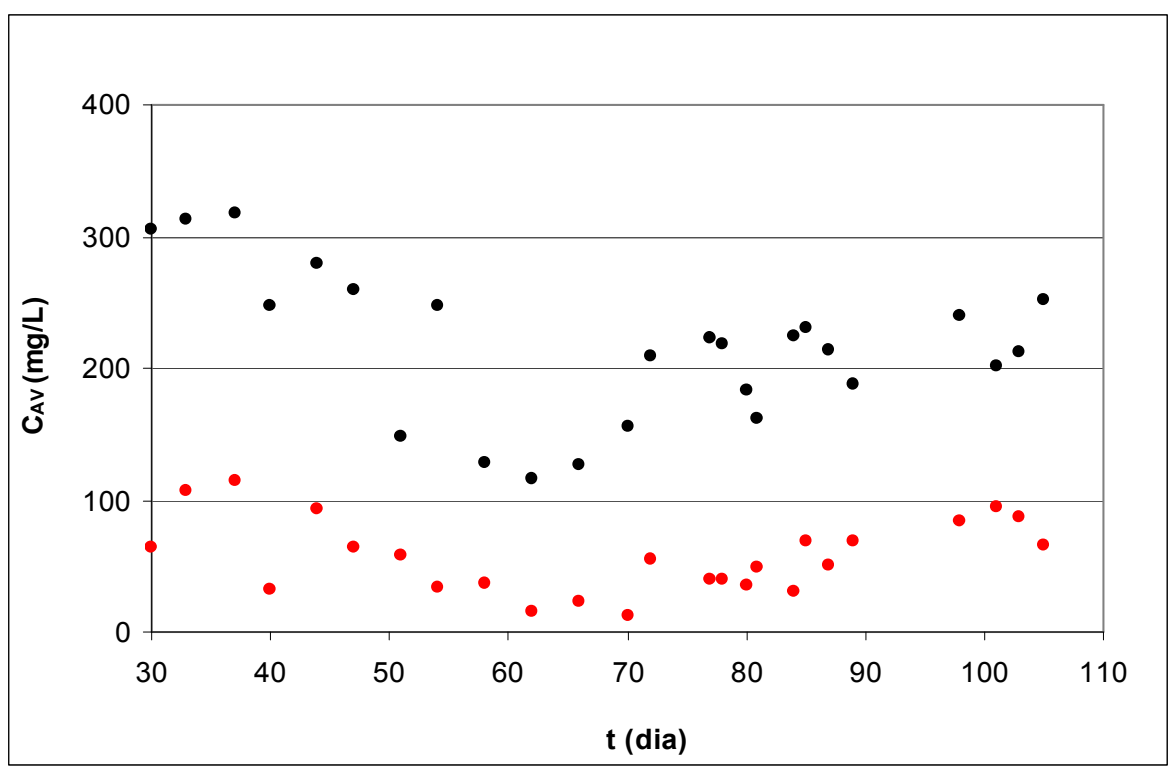

Figura 5.38 - Variação temporal da concentração afluente de cada ácido volátil do RALF tratando efluente sintético para os outros dias de operação (do dia 26 ao dia 105).

(•) ácido acético e (•) ácido propiônico.

A Figura 5.38 mostra que uma parte da glicose afluente se transformou em ácidos acético e propiônico. Outros ácidos voláteis foram visualizados através de pequenos "picos" nos resultados da cromatografia, mas na quantificação das concentrações (feita pelo próprio método) eles não foram apresentados, mostrando que suas concentrações não foram detectadas pelo método.

No período em questão, as temperaturas máxima e mínima encontradas no ambiente externo à cabine foram de, respectivamente, $11^{\circ} \mathrm{C}$ e $28^{\circ} \mathrm{C}$. Dentro da cabine, as temperaturas máxima e mínima encontradas, para o mesmo período, foram respectivamente de $21^{\circ} \mathrm{C}$ e $32^{\circ} \mathrm{C}$. Como já foi observado anteriormente, os instrumentos de medida utilizados nesse período, com registros apenas de temperaturas máximas e mínimas, não permitiram uma análise muito elaborada dos efeitos da temperatura, além da percepção de que a cabine cumpriu um ótimo papel de "amortecer" as temperaturas externas e com isso expor o sistema experimental a melhores condições térmicas. Um exemplo é que sua temperatura interna mínima foi de $21^{\circ} \mathrm{C}$, mesmo com o ambiente externo apresentando temperaturas mínimas de $11^{\circ} \mathrm{C}$. 
Em virtude das elevadas temperaturas máximas dentro da cabine (por exemplo, $32^{\circ} \mathrm{C}$ ), mesmo com temperaturas externas bem menores, nas estações do ano que se caracterizam por temperaturas mais amenas (outono e inverno), ocorreu nessa época uma certa preocupação quanto ao comportamento do reator com as temperaturas maiores, que seriam atingidas no verão. Até então não havia sido possível monitorar as temperaturas do líquido no reator, embora os dados de desempenho demonstrem que não estavam ocorrendo efeitos adversos causados pela temperatura. Essa temperatura elevada dentro da cabine não foi causada apenas pelos efeitos de irradiação e dissipação de calor, mas também devido ao aquecimento provocado pela bomba de recirculação, já que esta bomba pode ser entendida como um motor elétrico em elevada rotação, produzindo, como conseqüência, calor. Se esse calor produzido não conseguisse se dissipar pelo ar, poderia ocorrer um aquecimento demasiado do líquido recirculado, e também dentro da cabine. De maneira preventiva, após a operação do reator sem o PCP, e já com os 3 termopares para registro de temperatura instalados, a bomba de recirculação foi colocada na parte externa à cabine (Figura 5.39) e perto dela foi colocado um ventilador funcionando ininterruptamente. Além disso, as janelas da cabine foram deixadas abertas para transferência de calor com o ambiente externo. Os resultados das temperaturas com essa nova configuração são mostrados no próximo capítulo, quando o desempenho do reator com PCP for abordado.

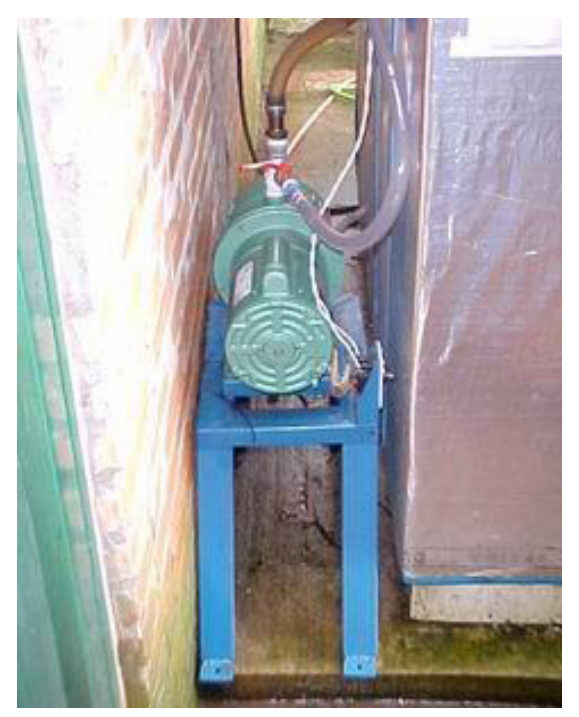

Figura 5.39 - Bomba de recirculação colocada para fora da cabine antes da introdução do PCP no reator A. 


\subsubsection{DISCUSSÕES SOBRE A ETAPA DE OPERAÇÃO DO RALF A SEM O PCP E DIFICULDADES ENCONTRADAS}

Basicamente os problemas que ocorreram durante a operação do reator A sem PCP, além dos que já foram relatados na discussão do capítulo de resultados, foram muito semelhantes aos apresentados pelo reator B. Pelos mesmos motivos que para o reator $\mathrm{B}$, foi impossível medir a produção de gás pelo sistema de deslocamento de líquido. Além disso, foram notadas as mesmas oscilações na expansão do leito, e conseqüentemente foram tomados os mesmos cuidados para que essa expansão ficasse próxima de $35 \%$. 0 reator $\mathrm{A}$, entretanto, não apresentou problemas de expulsão de partículas.

Mesmo sendo aparentemente possível diminuir ainda mais o tempo de detenção hidráulica, em virtude da elevada eficiência apresentada e dos outros parâmetros de monitoramento apresentarem comportamento típico de reatores anaeróbios, as condições de operação da fase $\mathrm{V}$ foram definidas como apropriadas para a introdução do PCP.

É importante relatar novamente que os reatores comumente utilizados no LPB para investigações semelhantes foram construídos em escala muito menor do que a utilizada, com vazões de alimentação menores que $1 \mathrm{~L} / \mathrm{dia}$. $\mathrm{O}$ reator do trabalho, alimentado com um efluente sintético com uma vazão de 48 L/dia, estava operando (de maneira intencional) em condições bem próximas ao "limite executável" em escala de laboratório.

Obviamente que surgem certos inconvenientes com o aumento de escala. Cuidados que sempre são tomados em reatores de menor escala não foram possíveis para esta situação em particular, como por exemplo, autoclavar o substrato para manutenção das suas principais características, e saturá-lo com nitrogênio para manutenção do ambiente anaeróbio. Além disso, os processos burocráticos para a importação de compostos organoclorados são demorados e nem sempre bem-sucedidos. Como o LPB dispunha de uma quantidade limitada de PCP em estoque, porém plenamente apropriada para utilização, procurou-se adaptar a parte experimental à oferta desse reagente.

A etapa de funcionamento do reator A sem o PCP foi muito importante pelo aprendizado que proporcionou, tanto pela experiência adquirida com os problemas que surgiram, como com todos os cuidados operacionais que $o$ 
sistema exigia. Programada inicialmente para ser uma etapa "transitória", ou seja, apenas de preparação do reator para a introdução do PCP, ela acabou revelando aspectos muito interessantes que ainda necessitam de maiores investigações, como a influência da variação do volume de reação no desempenho do reator. Obviamente que o trabalho em si faz apenas uma pequena contribuição ao assunto. Devido a sua importância, serão necessários trabalhos exclusivamente direcionados para esta finalidade.

Como o reator apresentou sempre uma resposta muito rápida às mudanças operacionais, essa fase foi sendo "moldada" de acordo com essas respostas. Nesta etapa, foi possível analisar o desempenho do reator diante de 3 diferentes situações operacionais: variação na carga orgânica, variação na carga hidráulica e variação do volume de reação.

Com o reator operando segundo os parâmetros descritos na fase $\mathrm{V}$ da Tabela 5.12, e com todo o aparato experimental de monitoramento da temperatura instalado e funcionando normalmente, o sistema foi considerado apto a receber o PCP, dando início à última etapa do trabalho.

\subsection{DESEMPENHO DO REATOR A COM PCP}

\subsubsection{DESCRIÇÃO DAS FASES OPERACIONAIS}

A Tabela 5.18 mostra os parâmetros operacionais do reator A no período de operação com o PCP. Uma concentração inicial de PCP de aproximadamente $1 \mathrm{mg} / \mathrm{L}$ foi introduzida, e as análises de desempenho começaram a ser realizadas a partir do $16^{\circ}$ dia de operação com PCP. Em sua totalidade, o reator funcionou por 95 dias, englobando os 15 dias em que não foram realizadas análises, e que portanto foram suprimidos deste item de resultados, e mais 80 dias de funcionamento com monitoramento. 
Tabela 5.18 - Informações e parâmetros operacionais do RALF A no período com PCP.

\begin{tabular}{cc}
\hline INFORMAÇÃO & DESCRIÇÃO \\
\hline Dias de operação & $95^{*}$ \\
$\mathrm{~d}_{\mathrm{p}}(\mathrm{mm})$ & 3,08 \\
DQO prevista no afluente $(\mathrm{mg} / \mathrm{L})$ & 1000 \\
TDH (horas) & 8,0 \\
Vazão afluente (L/dia) & 48 \\
C.O. (g DQO/dia) & 48 \\
T.C.O. (g DQO/L.dia) & 3,0 \\
Altura estática do leito (cm) & 60 \\
Quantidade de biomassa (mgSSV / gCAG) & 6,3 \\
Expansão do leito (\%) & 35 \\
\hline Obs.: * equivalente a 15 dias sem análises e 80 dias com análises \\
C.O.: carga orgânica \\
T.C.O.: taxa de carregamento orgânico
\end{tabular}

A Tabela 5.19 mostra um quadro resumo com as fases de operação do reator $\mathrm{A}$ depois da colocação do PCP no sistema. Durante a operação do reator A com PCP, todos os parâmetros operacionais apresentados na Tabela 5.18 foram mantidos.

Tabela 5.19- Fases operacionais e suas respectivas concentrações de PCP aplicadas ao RALF A utilizado na pesquisa.

\begin{tabular}{cccc}
\hline FASE & Dias & $\begin{array}{c}\mathbf{C}_{\text {PCP }} \\
(\mathbf{m g} / \mathbf{L})\end{array}$ & $\begin{array}{c}\text { Total de } \\
\text { Dias }\end{array}$ \\
\hline VI & $0-7$ & 1,0 & 7 \\
VII & $8-26$ & 2,0 & 19 \\
VIII & $27-52$ & 4,0 & 26 \\
IX & $53-80$ & 6,0 & 28
\end{tabular}

\subsubsection{MONITORAMENTO DA TEMPERATURA}

Em virtude do elevado número de pontos obtidos com o monitoramento da temperatura, já que foram cerca de 100 dias de registro, inicialmente de 10 em 10 minutos e depois de 30 em 30 minutos, concluiu-se que uma maneira 
mais adequada de apresentar os resultados seria através da escolha de "dias típicos".

Ao longo desse monitoramento, na medida em que as temperaturas foram colocadas em gráficos para uma melhor visualização da variação, observou-se que para muitos dias o comportamento foi extremamente semelhante, a ponto de ser possível dividir todos os 100 dias monitorados em algumas categorias (por exemplo, dias mais quentes, dias mais frios, dias com maior variação, dentre outras). Esboçá-los em sua totalidade seria repetição e mera ocupação de espaço.

Dessa maneira, as Figuras 5.40, 5.41 e 5.42 mostram, respectivamente, os valores obtidos para três dias típicos do período de 80 dias de operação do reator: dia com maior variação de temperatura, dia com temperatura mais alta e dia com a temperatura mais baixa. Nas três figuras, o tempo zero corresponde às 10 horas da manhã.

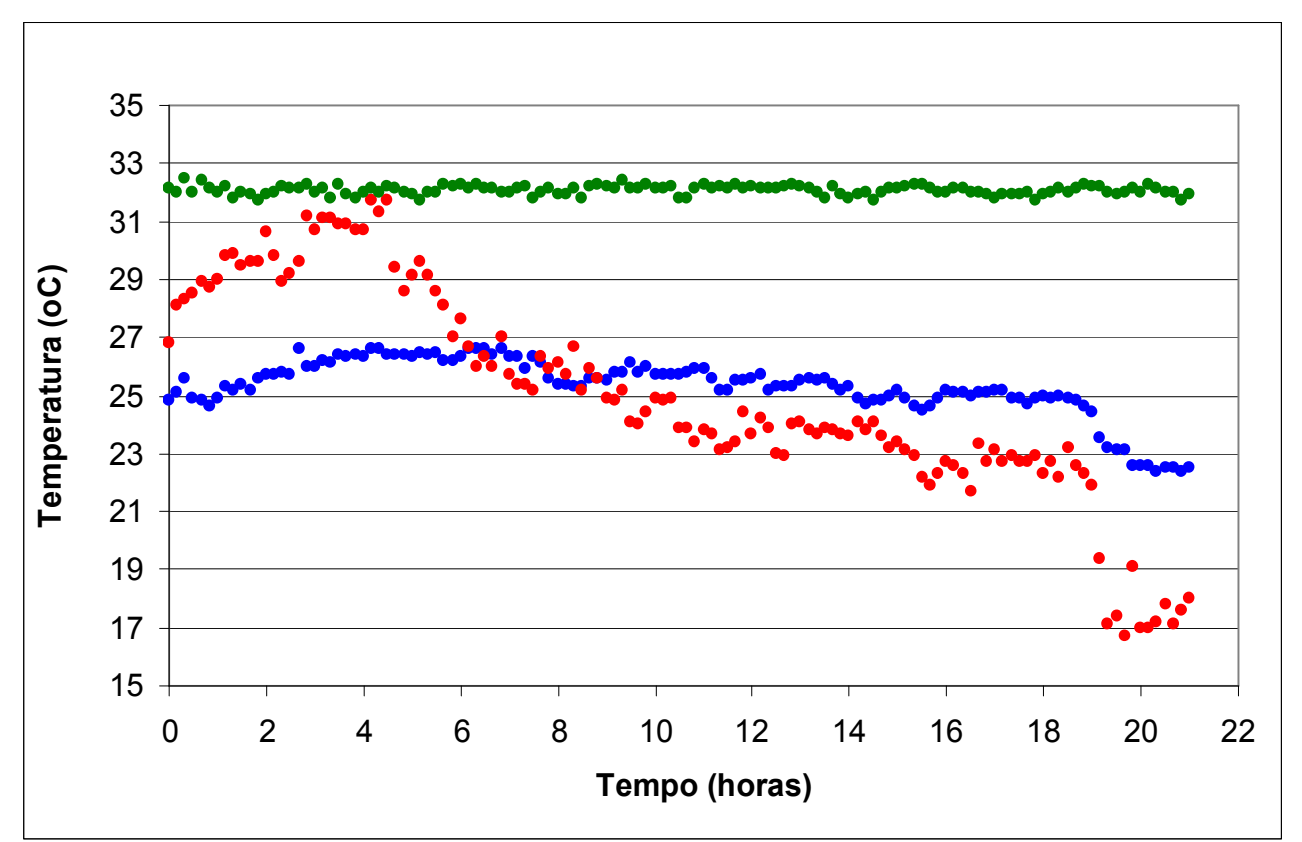

Figura 5.40 - Valores obtidos no monitoramento das temperaturas para um dia típico com grande variação de temperatura.

$(\bullet)$ temperatura externa $(\bullet)$ temperatura interna $(\bullet)$ temperatura no líquido dentro do reator (tempo zero: 10 hs da manhã). 


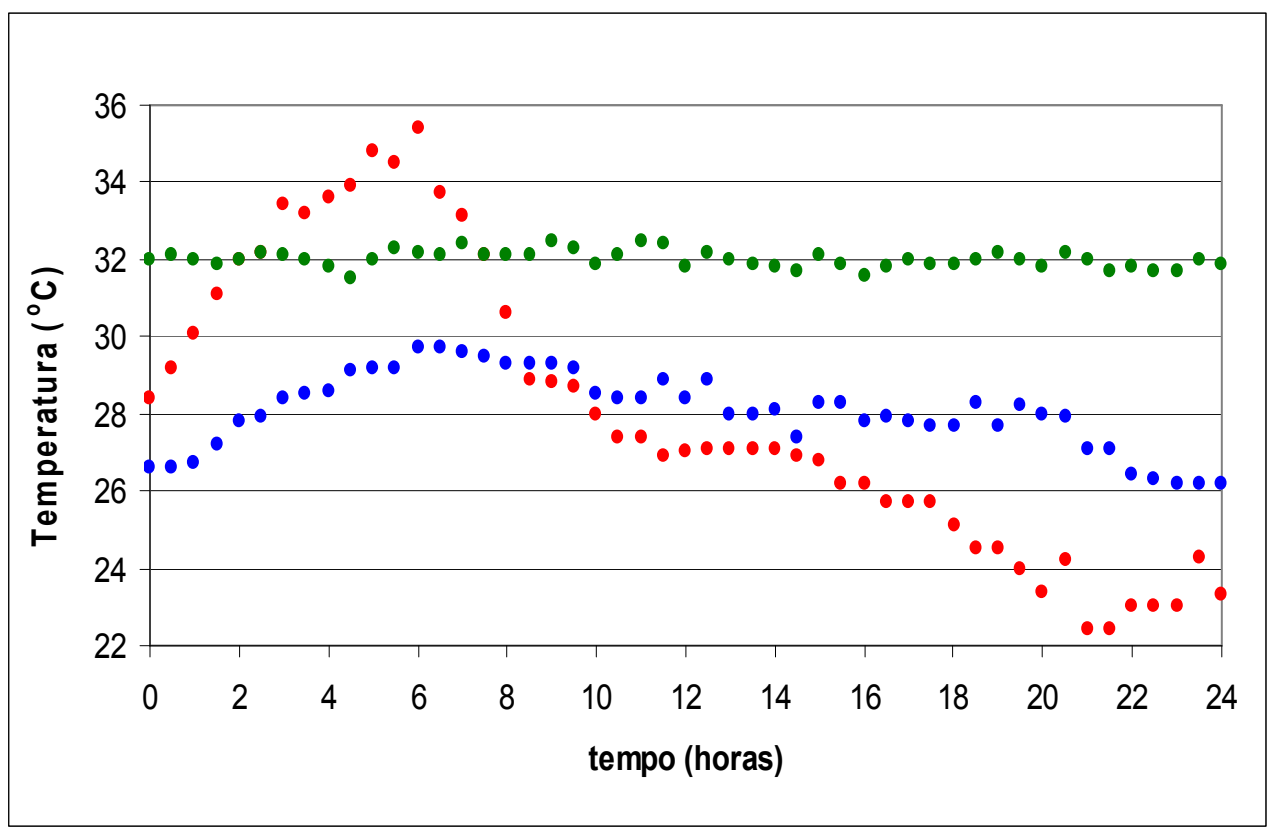

Figura 5.41 - Valores obtidos no monitoramento das temperaturas para um dia quente.

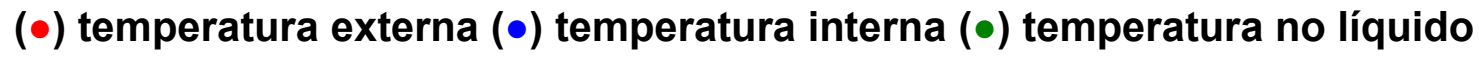
dentro do reator. (tempo zero: 10 hs da manhã)

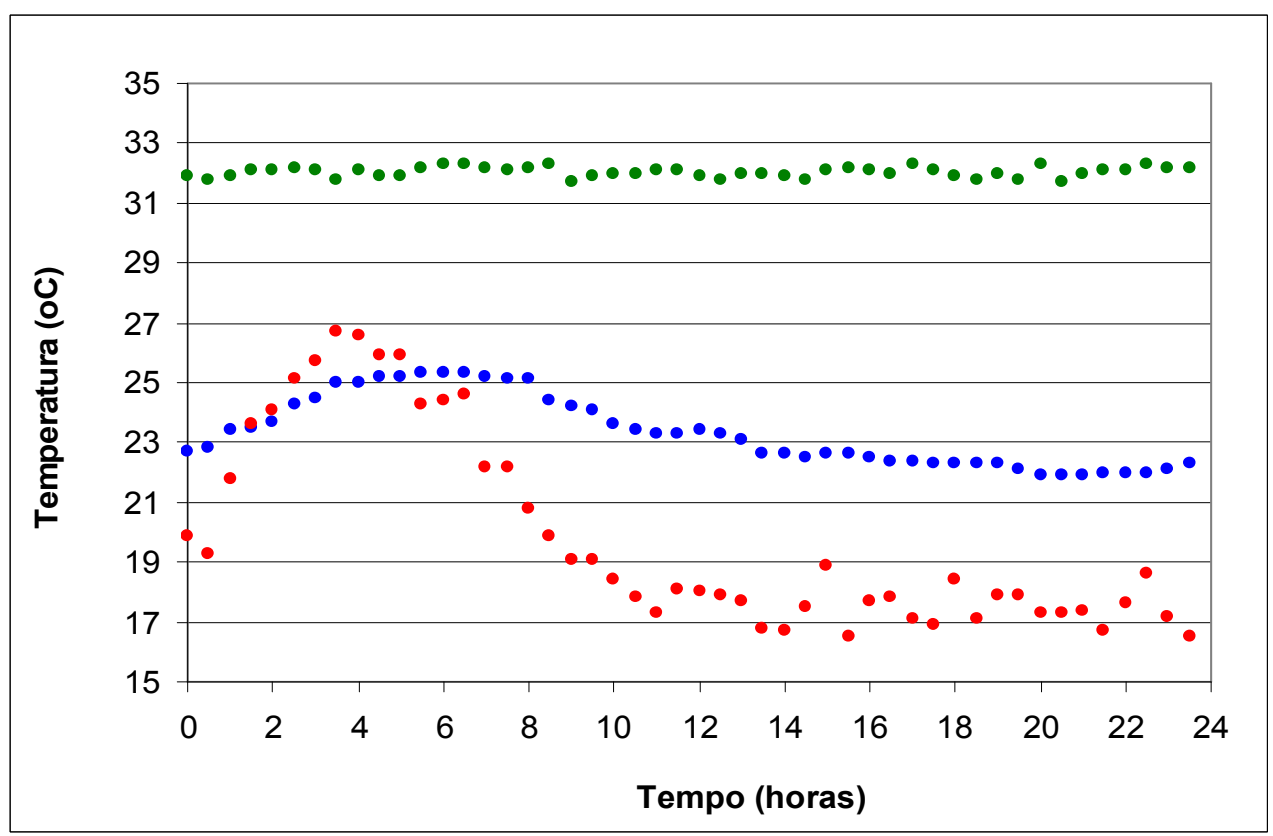

Figura 5.42 - Valores obtidos no monitoramento das temperaturas para um dia frio.

$(\bullet)$ temperatura externa $(\bullet)$ temperatura interna $(\bullet)$ temperatura no líquido dentro do reator (tempo zero: 10 hs da manhã) 
A Figura 5.40 mostra os resultados para um dia com grande variação de temperatura (cerca de $15^{\circ} \mathrm{C}$ ). Analisando as temperaturas, que foram registradas e apresentadas de 10 em 10 minutos, percebe-se que a variação dentro da cabine foi muito menor do que a variação externa, tanto neste dia como em todas as outras situações. Esse comportamento foi "padrão", mesmo para dias com temperaturas externas bem diferentes. A Figura 5.41 mostra o resultado obtido para o dia que registrou a temperatura mais alta do período monitorado e a Figura 5.42 o dia com temperatura mais baixa. Os valores máximos geralmente foram obtidos entre as 14 e $15 \mathrm{hs}$, e os valores mínimos de madrugada.

Com relação à temperatura do líquido dentro do reator, foi verificado que durante todo o período de registro ela permaneceu praticamente constante, com média de $(32,0 \pm 0,2)^{\circ} \mathrm{C}$. Essa particularidade pode ser bem visualizada nas Figuras 5.40, 5.41 e 5.42. Os resultados mostram claramente que ocorreu um "controle involuntário" para essa temperatura, e que este processo foi independente das variações que estavam ocorrendo externamente. Sabe-se que, de todas as temperaturas monitoradas, a do líquido recirculado foi a mais importante, pois foi aquela que realmente comandou todos os processos dentro do reator.

A explicação para tal comportamento está relacionada com um procedimento que já foi relatado neste capítulo de resultados, quando algumas medidas de prevenção para que não fossem atingidas elevadas temperaturas do líquido e dentro da cabine foram tomadas, dentre as quais destacam-se a colocação da bomba de recirculação para fora da cabine e a instalação de um ventilador para resfriamento da bomba. Essa nova configuração acabou se tornando um mecanismo indireto (e não intencional) de controle da temperatura do sistema experimental na faixa adequada aos processos anaeróbios. A idéia inicial era a de não se instalar nenhum equipamento eletrônico para controle rigoroso da temperatura, o que realmente foi cumprido, mas não se cogitou que a própria bomba de recirculação pudesse fazer esse papel. Não se sabe quais seriam os efeitos para o desempenho do reator se a bomba de recirculação fosse deixada dentro da cabine durante os meses de verão, por exemplo.

No final do experimento, a bomba de recirculação foi desligada e o reator ficou operando como leito fixo. Esse procedimento foi tomado apenas 
por curiosidade, para verificar a variação da temperatura no líquido sem o aquecimento causado pela bomba de recirculação. A Figura 5.43 mostra os resultados obtidos para essa configuração.

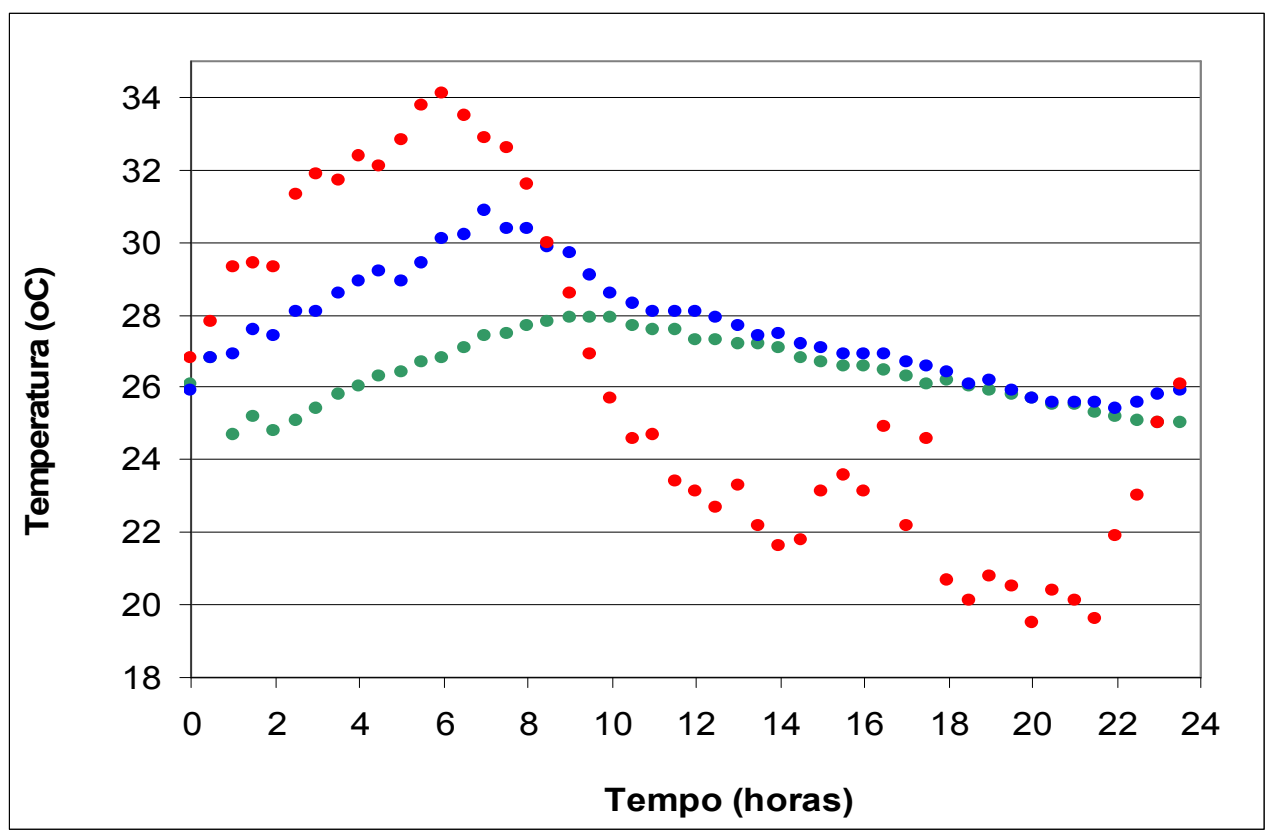

Figura 5.43 - Valores obtidos no monitoramento das temperaturas para o reator A operando como leito fixo.

$(\bullet)$ temperatura externa $(\bullet)$ temperatura interna $(\bullet)$ temperatura no líquido dentro do reator

Pelo que se observa analisando a Figura 5.43, é possível notar que a variação da temperatura no líquido no reator de leito fixo em questão, protegido dos raios solares e das intempéries e sem a energia térmica fornecida pela bomba de reciclo, foi maior do que na situação de leito fluidificado e com comportamento que ficou bem mais próximo ao obtido para as temperaturas dentro da cabine. Mesmo assim, das três temperaturas monitoradas, a do líquido ainda foi a que apresentou a menor variação.

Uma análise geral da literatura mostrou que a maioria dos trabalhos experimentais envolvendo processos biológicos possui dispositivos para rigoroso controle de temperatura, o que nem sempre representa as condições reais desses reatores em indústrias ou estações de tratamento. Muitas vezes tais sistemas ficam submetidos às variações diárias de temperatura, e essa condição pode representar uma perda na eficiência do tratamento, mas por outro lado acarreta uma economia de custos pela ausência de dispositivos de 
controle, que dependendo da escala dos equipamentos, pode ser de proporções elevadas. Um número menor de equipamentos também pode significar menor possibilidade de quebras, e maior facilidade de operação.

O que se observou é que em reatores de leito fluidificado, nas condições utilizadas, o próprio sistema de reciclo já forneceu energia suficiente para manter o reator próximo das condições isotérmicas. É bem provável que em um país tropical, como o Brasil, a simplificação proveniente da ausência desses sistemas de controle seja amplamente possível e, por fim, a utilização de complexos sistemas de controle de temperatura (na faixa de $30^{\circ} \mathrm{C}$ ) em diferentes escalas e configurações de reatores biológicos, necessita de uma avaliação mais aprofundada.

\subsubsection{ANÁLISES DE MICROSCOPIA}

As amostras de biopartículas foram retiradas do reator $\mathrm{A}$, para análises de microscopia óptica, nos seguintes dias de operação sem PCP: $30^{\circ}, 105^{\circ}$, e no último dia de operação com PCP $\left(80^{\circ}\right)$. As análises e discussões dos resultados serão realizadas após a apresentação das imagens. A Figura 5.44 apresenta os resultados obtidos para microscopia óptica em amostras coletadas no $30^{\circ}$ dia de operação do reator A sem PCP. As Figuras 5.45 e 5.46 apresentam, respectivamente, os resultados obtidos para microscopia óptica e MEV em amostras coletadas no $105^{\circ}$ dia de operação do reator A sem PCP. As Figuras 5.47 e 5.48 apresentam, respectivamente, os resultados obtidos para microscopia óptica e MEV em amostras coletadas no $80^{\circ}$ dia de operação do reator A com PCP. 


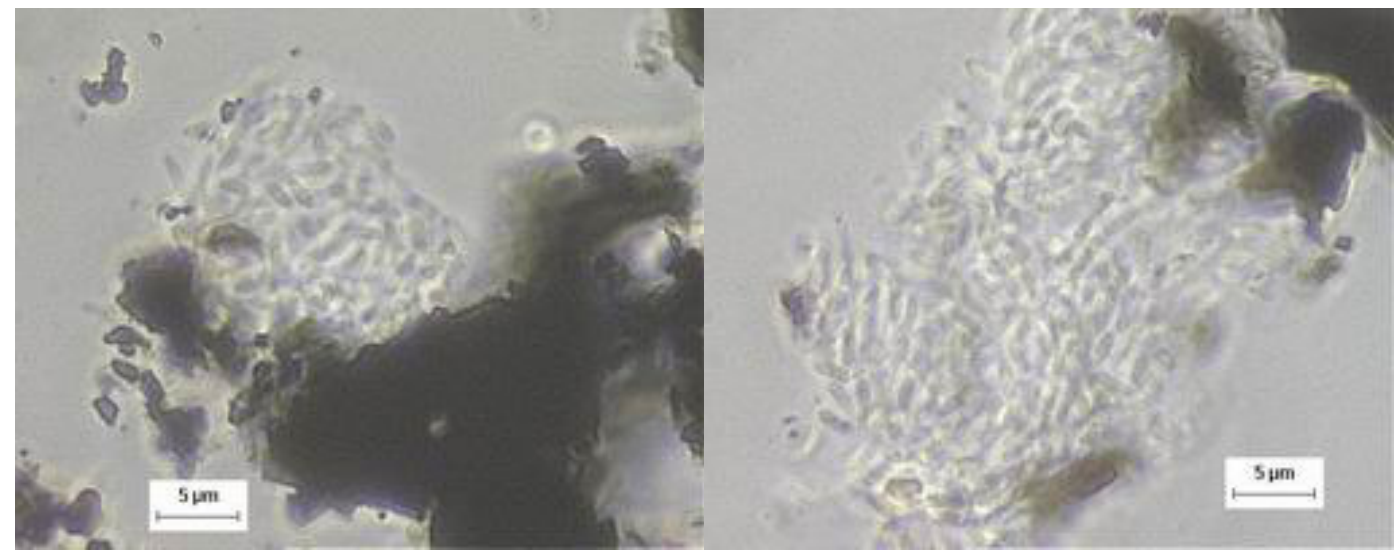

(a)

(b)

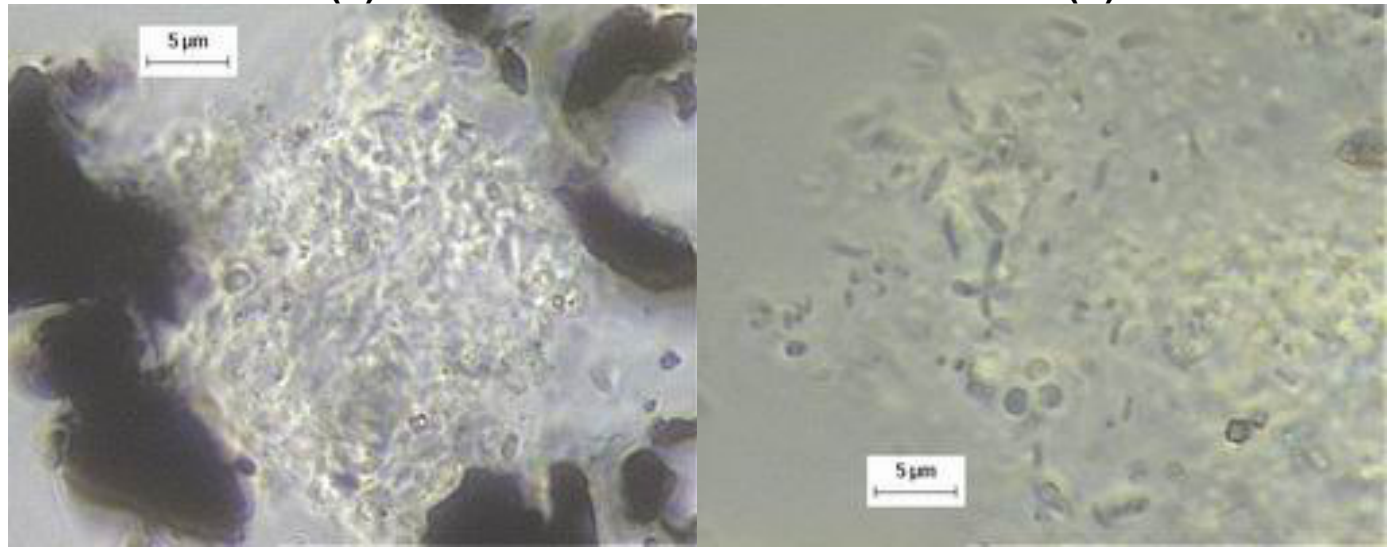

(c)

(d)

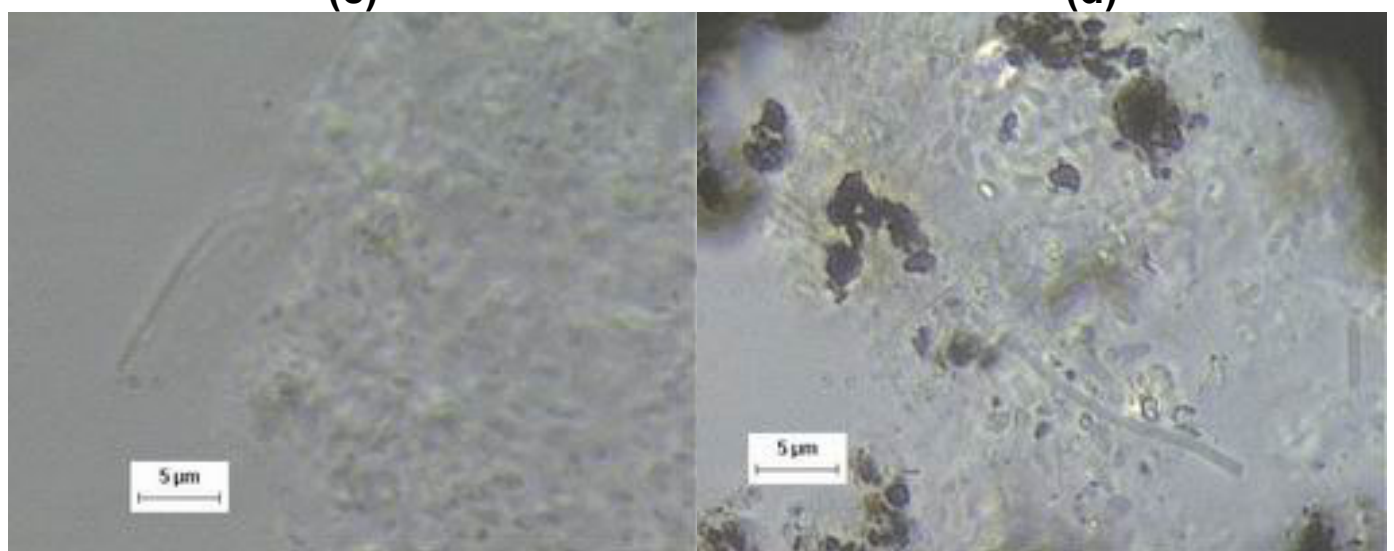

(e)

(f)

Figura 5.44 - Fotomicrografias realizadas nas amostras de biopartículas coletadas no $30^{\circ}$ dia de operação do reator A sem PCP.

(a), (b), (c) células semelhantes a bacilos não fluorescentes (d) células semelhantes a cocos e bacilos não fluorescentes; (e) e (f) células semelhantes a bacilos e bactérias filamentosas não fluorescentes. 


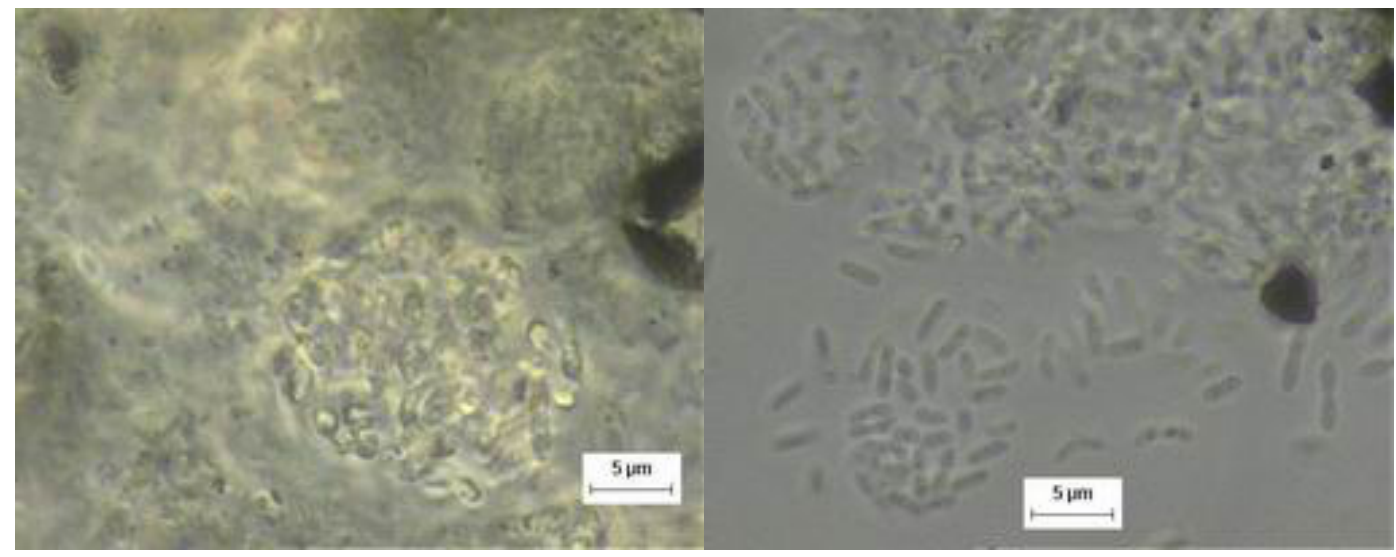

(a)

(b)

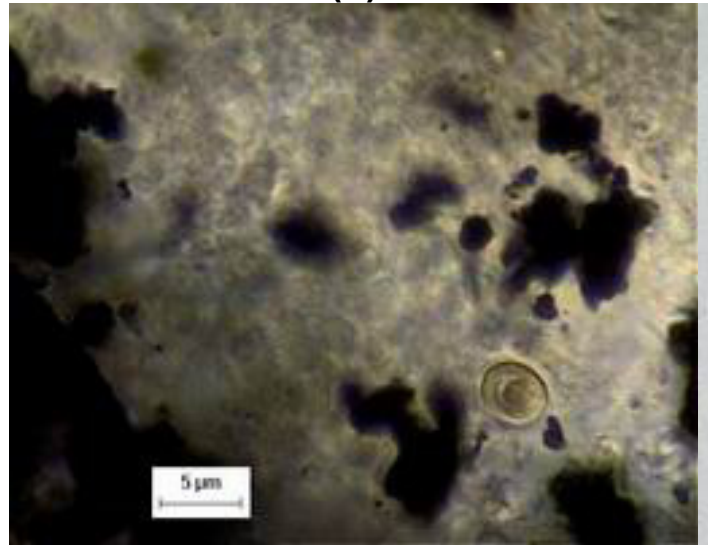

(c)

(d)

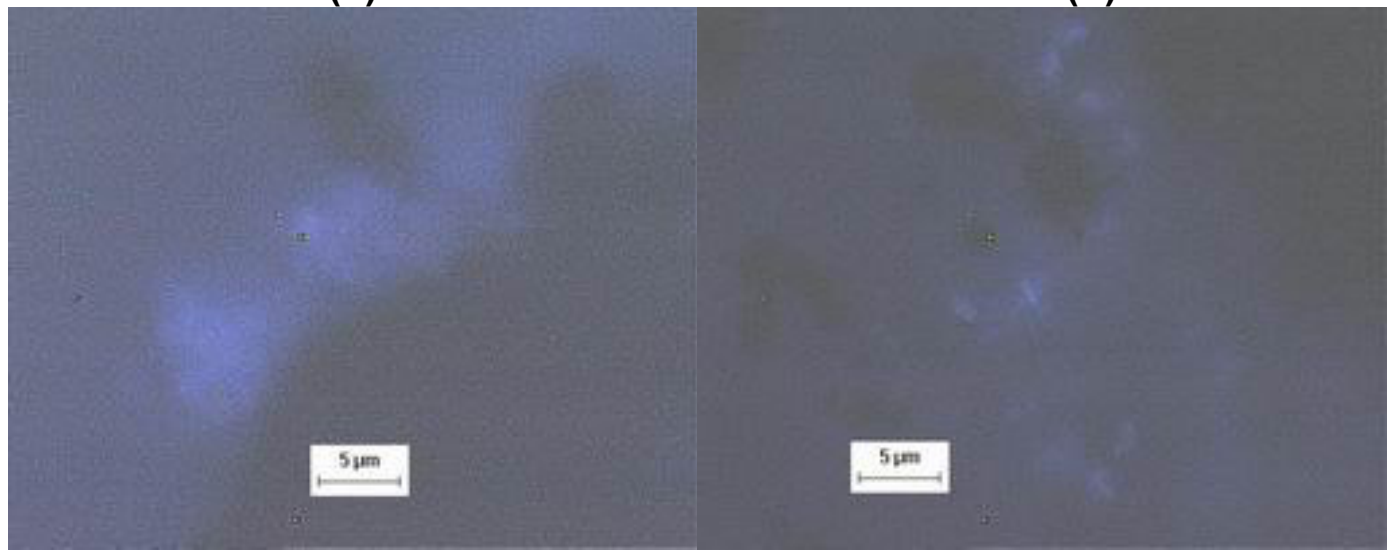

(e)

(f)

Figura 5.45 - Fotomicrografias realizadas nas amostras de biopartículas coletadas no $105^{\circ}$ dia de operação do reator A sem PCP.

(a) arranjo de células semelhantes a bacilos não fluorescentes (b) células semelhantes a bacilos não fluorescentes, com inclusões (c) células semelhantes a cocos não fluorescentes (d) células semelhantes a methanosarcina $s p(e)$ células semelhantes a methanosarcina $s p$ analisadas sob fluorescência (f) células semelhantes a bacilos analisados sob fluorescência. 


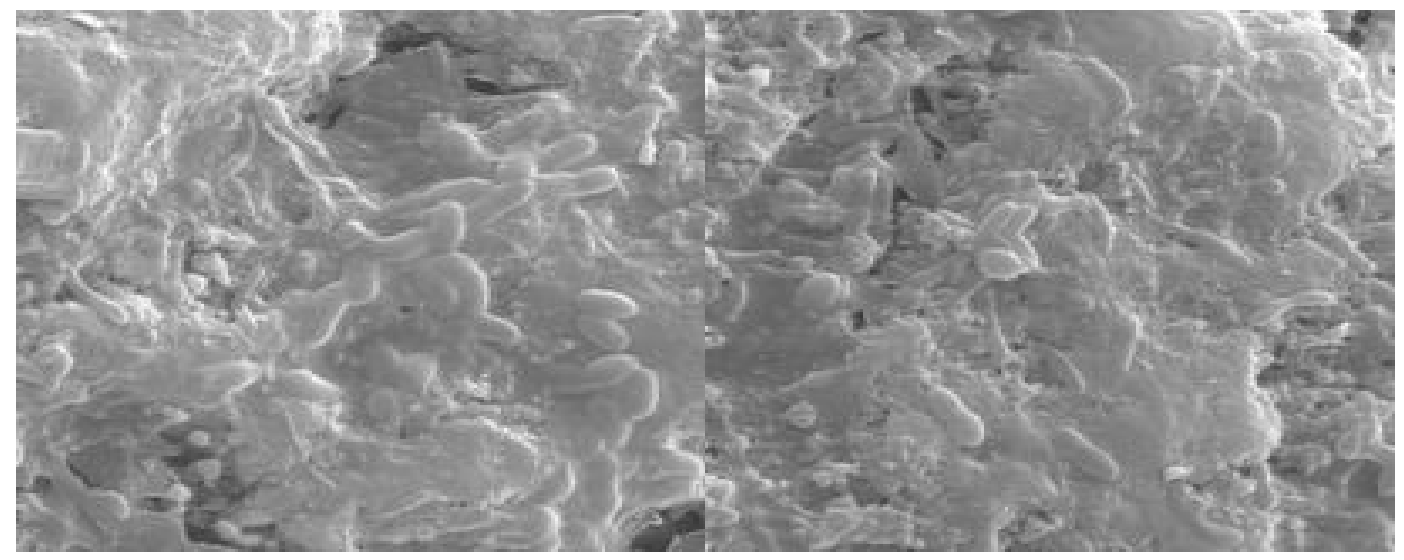

(a)

(b)

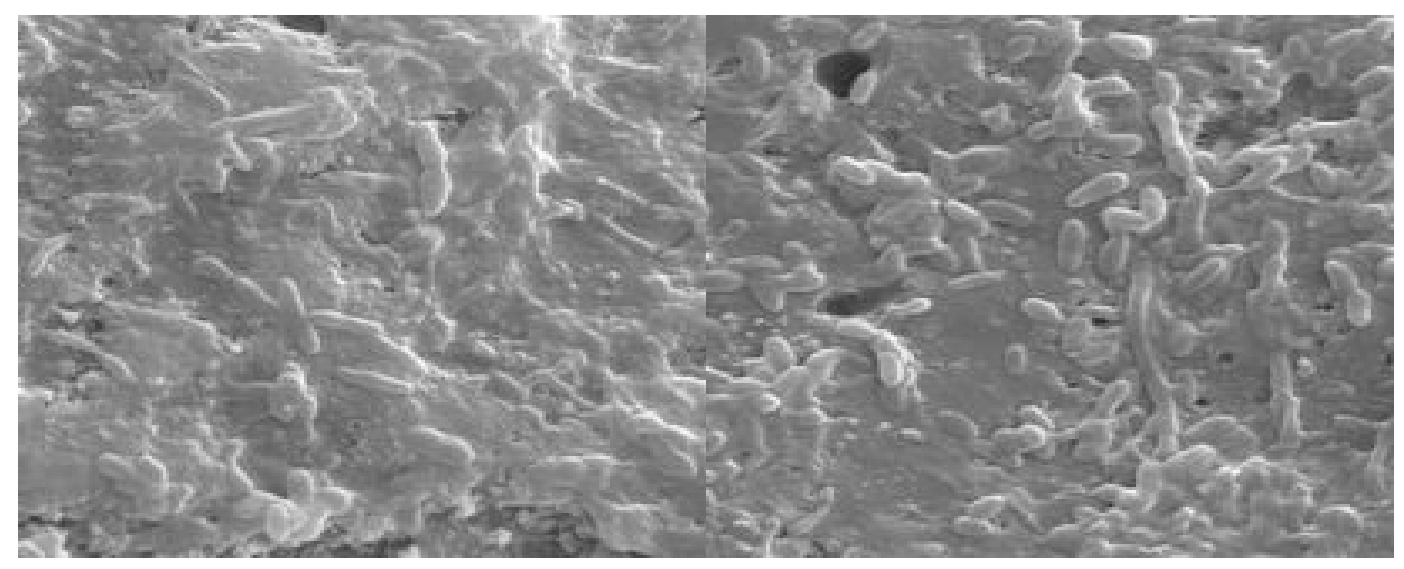

(c)

(d)

Figura 5.46 - Fotomicrografias (MEV) realizadas nas amostras de biopartículas coletadas no $105^{\circ}$ dia de operação do reator A sem PCP. (a), (b), (c) e (d) células semelhantes a bacilos. 


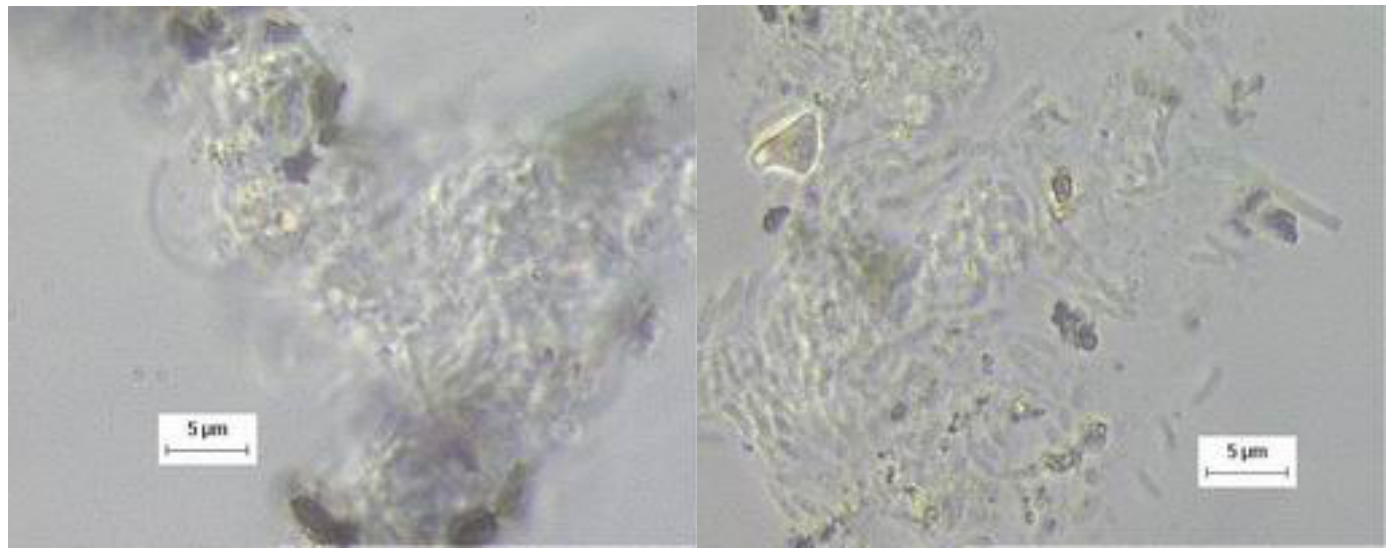

(a)

(b)

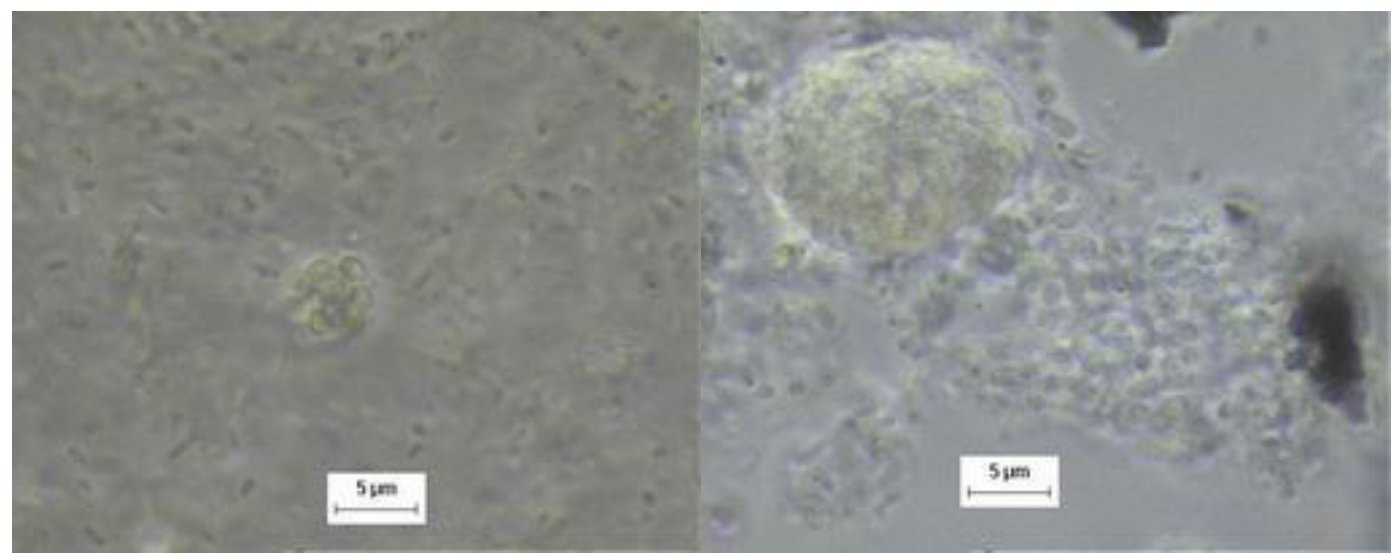

(c)

(d)

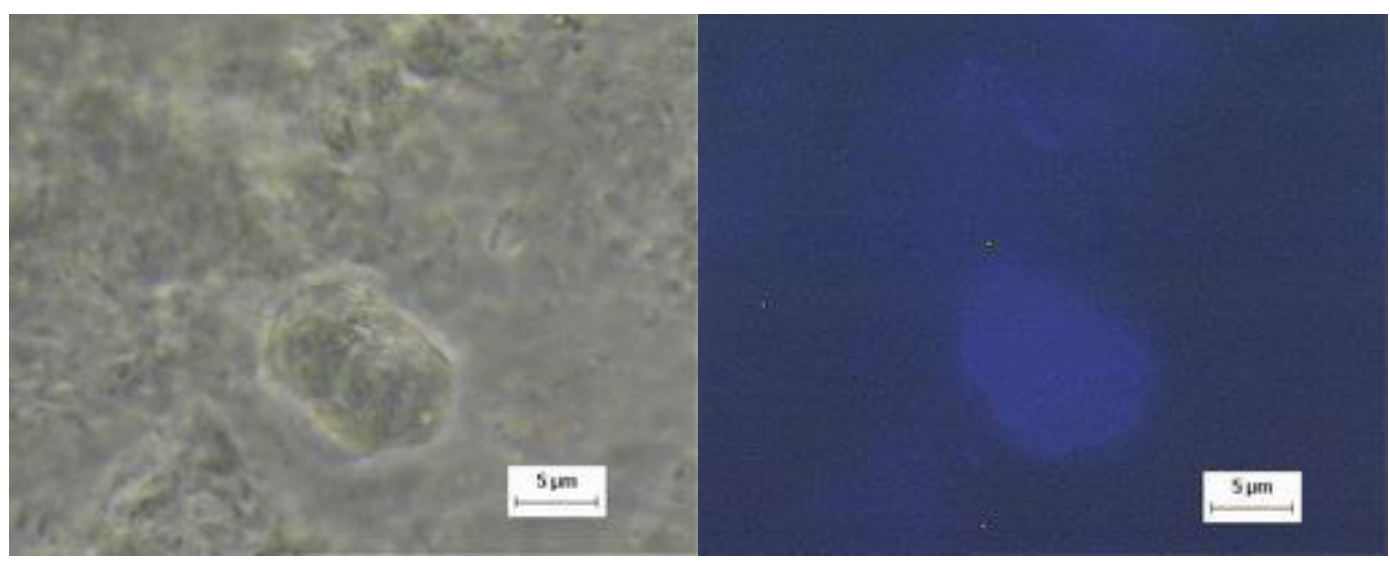

(e)

(f)

Figura 5.47 - Fotomicrografias realizadas nas amostras de biopartículas coletadas no $80^{\circ}$ dia de operação do reator A com PCP.

(a) e (b) células semelhantes a bacilos não fluorescentes e bactérias filamentosas (c) e (d) células semelhantes a bacilos e cocos não fluorescentes (e) células semelhantes a methanosarcina $s p$ (f) células semelhantes a methanosarcina $s p$ analisadas sob fluorescência. 


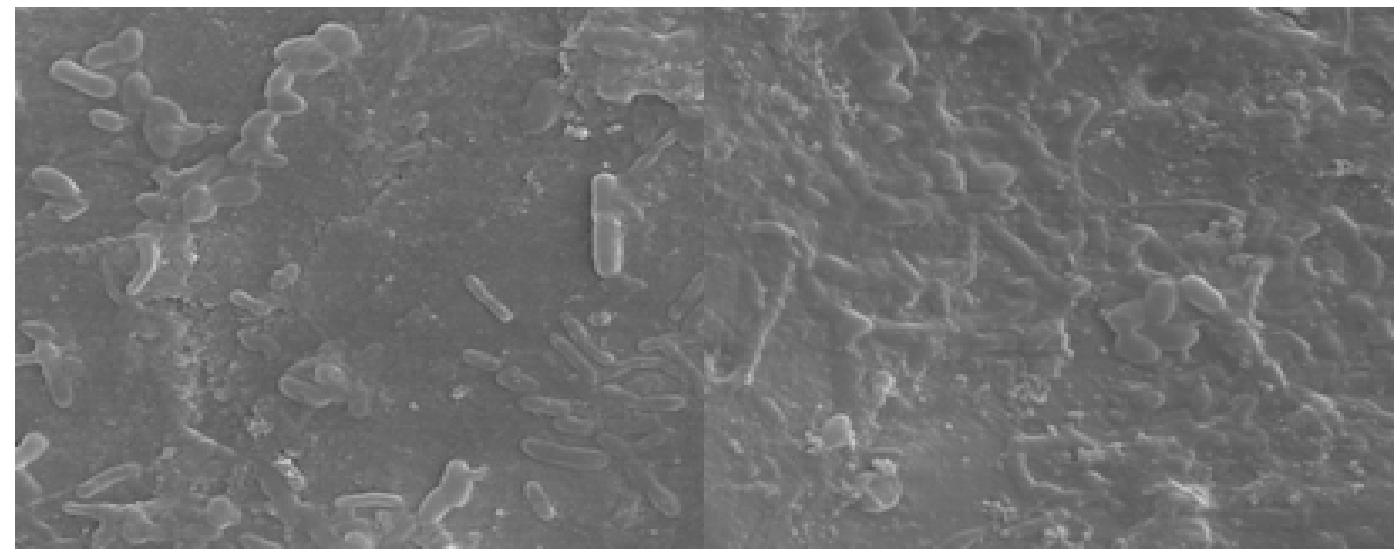

(a)

(b)

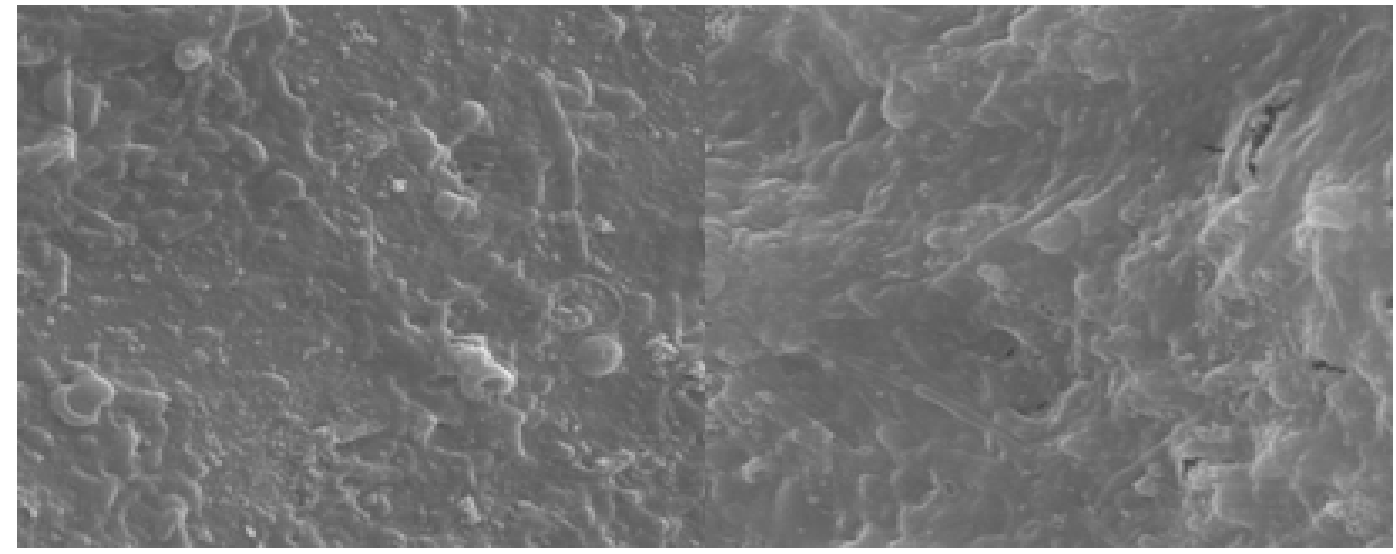

(c)

(d)

Figura 5.48 - Fotomicrografias (MEV) realizadas nas amostras de biopartículas coletadas no $105^{\circ}$ dia de operação do reator A sem PCP. (a), (b), (c) e (d) células semelhantes a bacilos.

Os resultados de todas as análises de microscopia óptica indicaram a predominância de uma grande quantidade de bacilos não metanogênicos (não fluorescentes) em formatos variados. Apesar da presença em quantidade bem menor, também foram detectados outros tipos de células, semelhantes a cocos, bactérias filamentosas, bacilos metanogênicos, cistos de methanosarcina $s p$ e methanosarcina $s p$.

As três análises realizadas apresentaram resultados muito similares no que diz respeito à variedade de microrganismos encontrados, tanto para a fase sem PCP, como para os 80 dias de operação com PCP, mostrando que esse composto tóxico no sistema, nas concentrações utilizadas, aparentemente não 
proporcionou mudanças significativas na qualidade da biomassa. A população metanogênica também não foi afetada com o aumento da concentração de PCP ao longo do experimento, visto que células semelhantes a methanosarcina sp foram encontradas tanto antes (Figura 5.45) como depois da operação do reator A com PCP (Figura 5.47). Diante das evidências obtidas, é possível concluir que a composição qualitativa da biomassa foi determinada pelas características particulares do efluente utilizado (fonte única de carbono e quantidade reduzida de matéria orgânica), e que essa composição não sofreu alterações com a presença de PCP nas concentrações que foram empregadas.

Os trabalhos do LPB relacionados com o mesmo tema, que utilizaram em seus respectivos efluentes várias fontes de carbono e elevada quantidade de matéria orgânica, apresentaram predominância de microrganismos metanogênicos (BOLAÑOS ROJAS, 1996; DAMIANOVIC, 1997; LARIZZATTI, 1997; BARALDI, 2001). Baraldi (2001) faz uma importante discussão em seu trabalho, indicando as espécies mais prováveis relacionadas a diferentes fontes de carbono, e também as espécies mais prováveis responsáveis pela desalogenação redutiva.

As análises de microscopia eletrônica de varredura também mostraram a predominância de bacilos. A ausência de outros microrganismos que foram detectados na microscopia óptica pode estar relacionada com casualidades na amostragem, já que as outras espécies apareceram em menor quantidade e, portanto, mais difíceis de serem encontradas. Uma outra possibilidade está relacionada com o arraste de biomassa provocado pelos sucessivos processos de lavagem que foram efetuados na preparação da amostra.

Em virtude das condições operacionais utilizadas e das observações ao longo do desenvolvimento do experimento (dentre elas a baixa produção de metano), os resultados obtidos nas análises de microscopia foram compatíveis com o que se esperava. A aplicação de condições menos idealizadas surgiu de uma verificação que se tornou uma das principais motivações do trabalho, ou seja, de que os reatores biológicos anaeróbios do LPB tratando PCP possivelmente estariam operando aquém de suas capacidades, tornando-se muito interessante analisar o efeito de condições mais simples no desempenho do reator. 


\subsubsection{VARIAÇÃO DOS PARÂMETROS DE MONITORAMENTO DO RALF A}

Os dados obtidos para desempenho do reator em termos de concentração de DQOI $\left(S_{b}\right)$ no afluente e no efluente, para as 4 concentrações de PCP aplicadas, são apresentados na Figura 5.49.

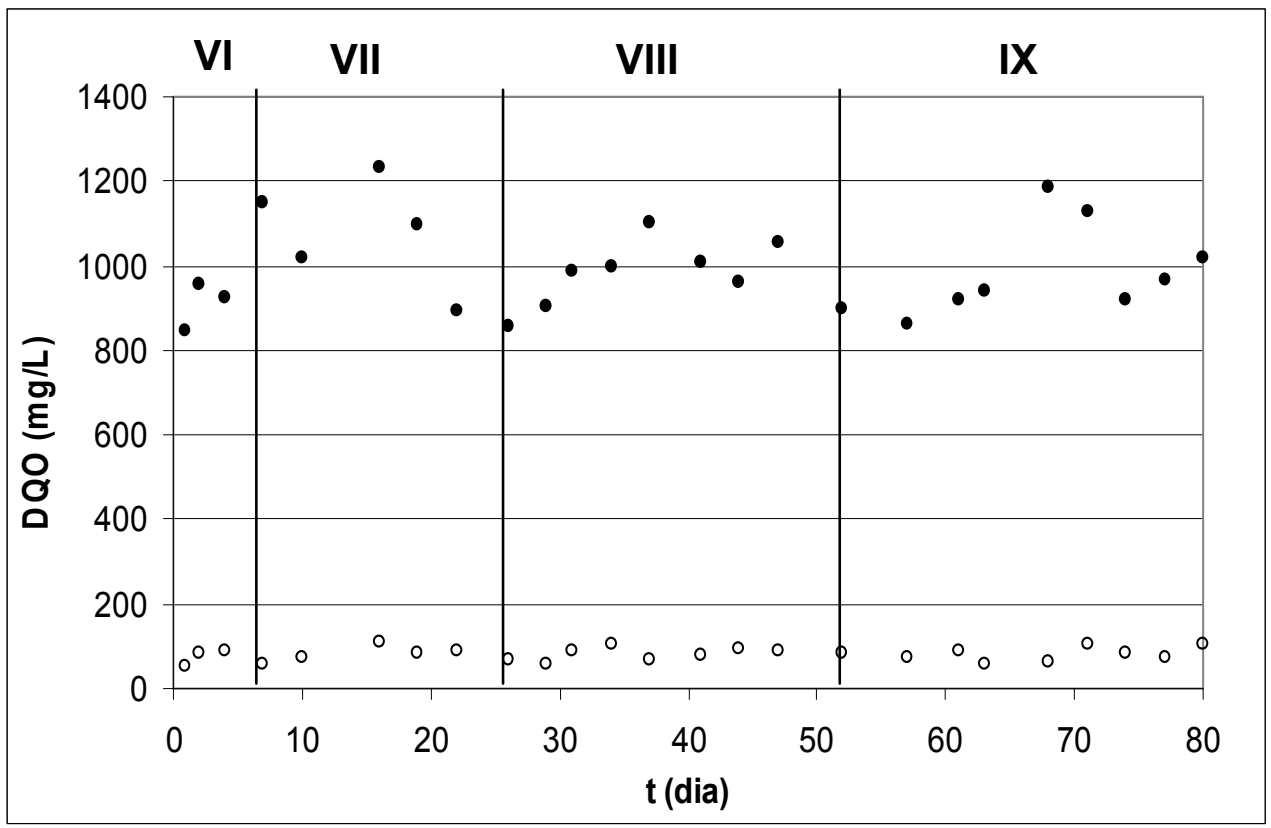

Figura 5.49 - Variação temporal da concentração de DQO no RALF A tratando substrato sintético com PCP.

(•) DQO afluente (o) DQO efluente.

A Figura 5.49 mostra que as variações nas concentrações de PCP afluente não alteraram o desempenho do reator $A$ com relação à remoção de DQO, característica que também pode ser verificada na Figura 5.50, que apresenta a eficiência de remoção de DQO ( $\left.E_{D Q O}\right)$ para o período. Dessa maneira, não se julgou necessário apresentar os parâmetros estatísticos específicos para cada fase, mas sim para todo o período de operação com PCP. 
Nos 80 dias de operação, foi obtida uma DQO afluente média de $(993,4$ $\pm 106,4) \mathrm{mg} / \mathrm{L}$, bem próxima do valor previamente estipulado de $1000 \mathrm{mg} / \mathrm{L}$, com valor máximo de $1233 \mathrm{mg} / \mathrm{L}$ e mínimo de $847 \mathrm{mg} / \mathrm{L}$. A DQO efluente média para o mesmo período foi de $(80,6 \pm 16,3) \mathrm{mg} / \mathrm{L}$, com valor máximo de 109 $\mathrm{mg} / \mathrm{L}$ e mínimo de $52 \mathrm{mg} / \mathrm{L}$. A eficiência média de remoção de DQO para o período de operação com PCP (fase VI a fase IX) foi de $(91,9 \pm 1,6) \%$, muito próxima da eficiência média de remoção de DQO atingida na fase $V(93,2 \pm$ $1,8) \%$ que, com exceção da ausência PCP, possuía os mesmos parâmetros operacionais. A eficiência mínima no período foi de $89,6 \%$ e a máxima de $95 \%$.

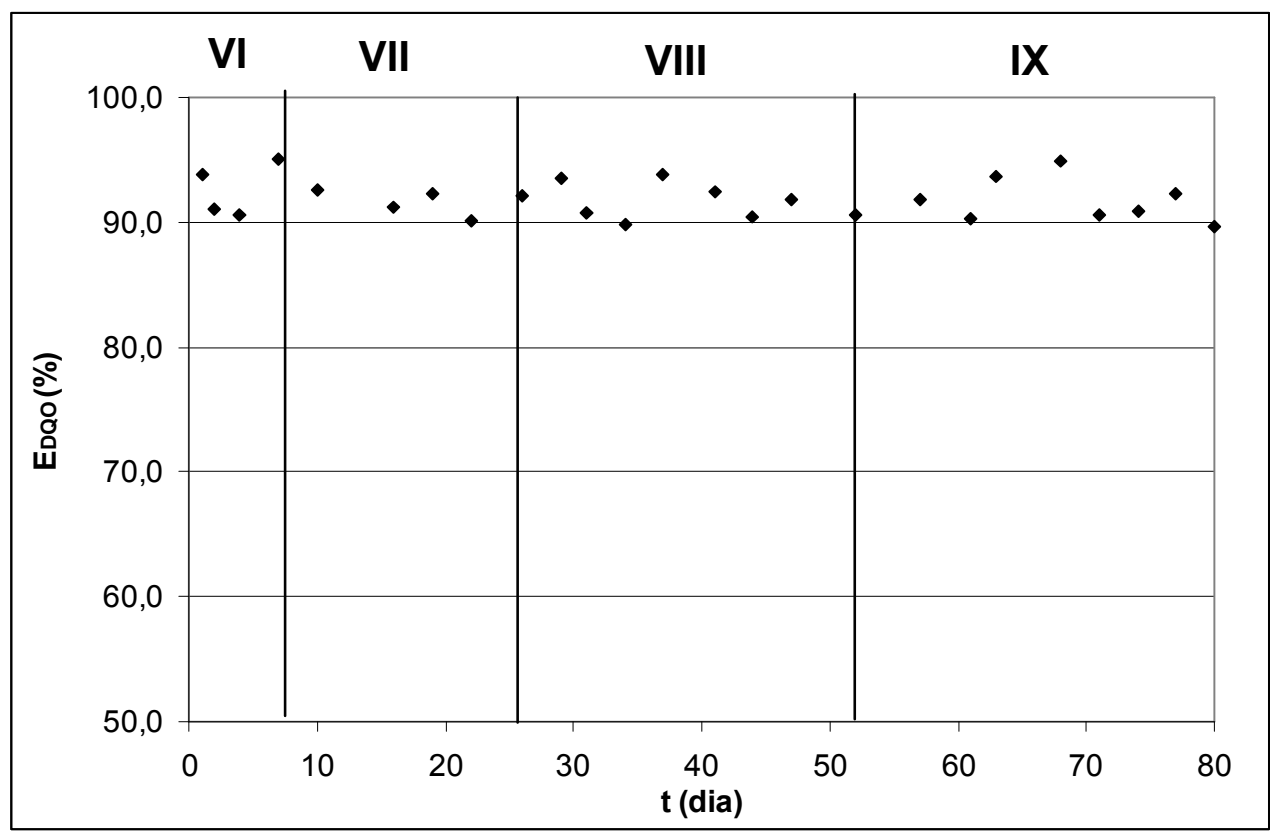

Figura 5.50 - Variação temporal da eficiência de remoção de DQO no RALF A tratando efluente sintético com PCP.

Diante destes resultados, foi possível concluir que, nas concentrações de PCP utilizadas neste trabalho, não houve um processo evidente de inibição da cinética por presença de substância tóxica.

As Figuras 5.51, 5.52 mostram, respectivamente, os resultados obtidos para a alcalinidade e o $\mathrm{pH}$. 


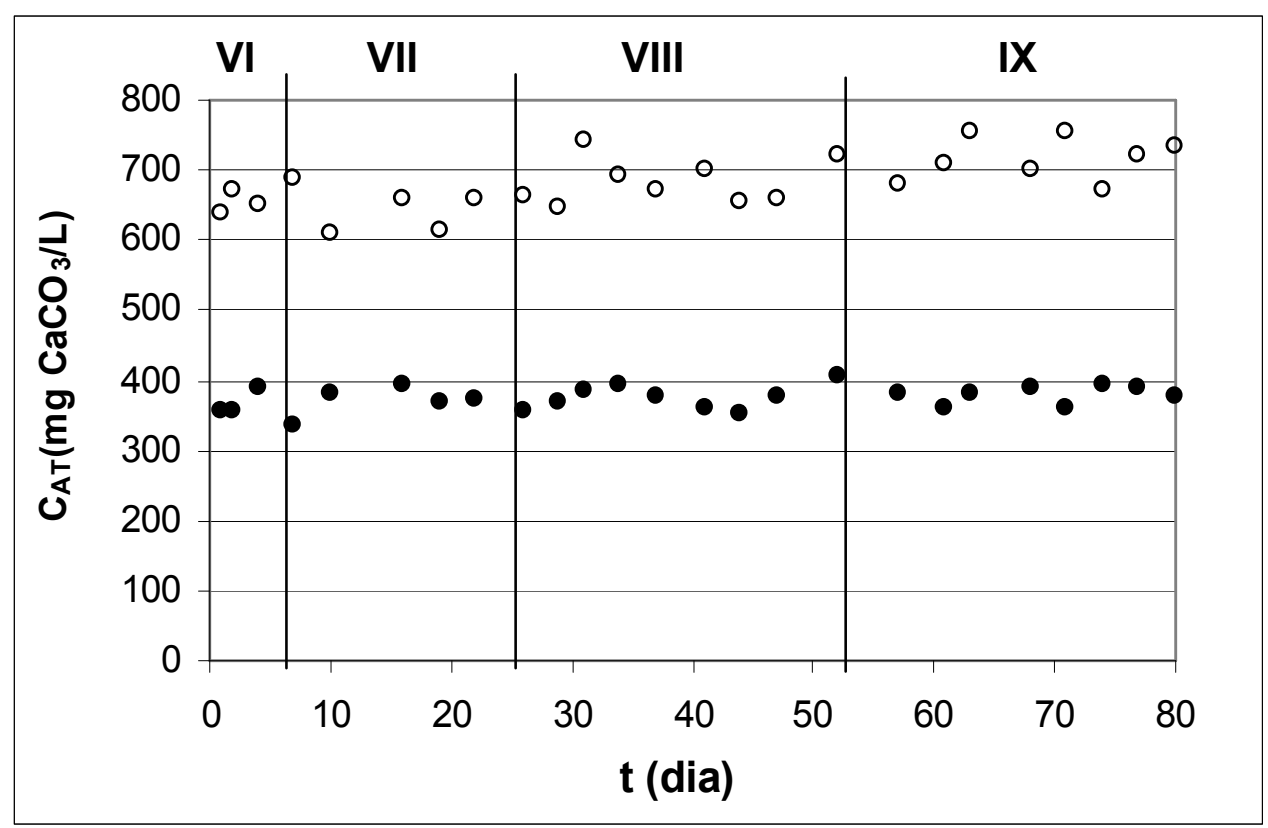

Figura 5.51 - Variação temporal da concentração de alcalinidade total $\left(A_{T}\right)$ do RALF A tratando efluente sintético com PCP.

(•) $A_{T}$ afluente e (o) $A_{T}$ efluente

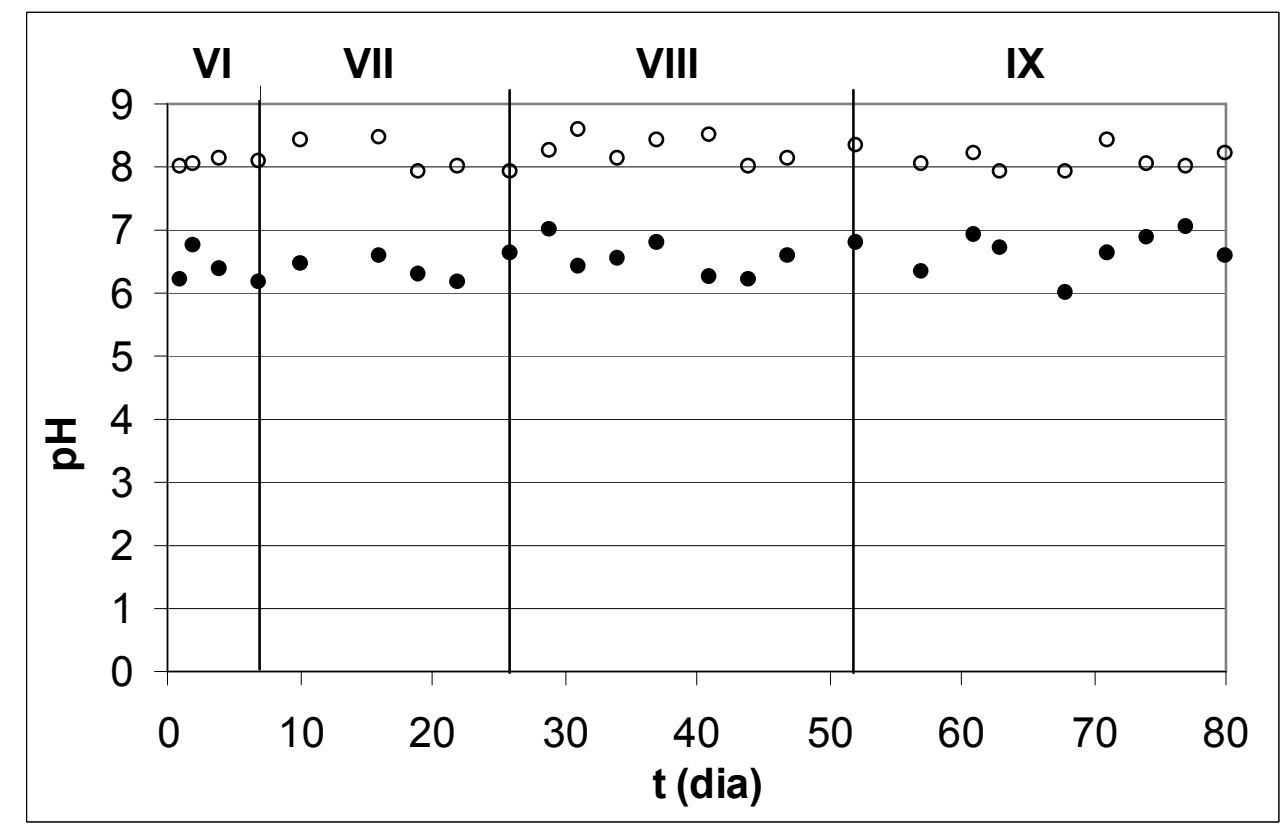

Figura 5.52 - Variação temporal dos valores de pH no RALF A tratando efluente sintético com PCP.

$(\bullet) \mathrm{pH}$ afluente (o) $\mathrm{pH}$ efluente. 
A alcalinidade total média no afluente, para os 80 dias de funcionamento com PCP, foi de $(374,6 \pm 16,2) \mathrm{mg} / \mathrm{L}$, com valor máximo de 405,4 mg/L e mínimo de $334,4 \mathrm{mg} / \mathrm{L}$. O reator anaeróbio na presença do composto tóxico também produziu alcalinidade, como pode ser observado nas concentrações efluentes. A média foi de $(682,3 \pm 39,0) \mathrm{mg} / \mathrm{L}$, com valor máximo de 753,2 $\mathrm{mg} / \mathrm{L}$ e mínimo de 610,2. Tendo em vista todas as fontes de desvio que podem interferir nos parâmetros, observou-se que tanto as médias como os desvios de alcalinidade foram muito próximos aos encontrados na última fase de funcionamento de reator A sem PCP.

A média dos valores de $\mathrm{pH}$ medidos no afluente foi de $(6,53 \pm 0,29)$, com valor máximo de 7,04 e mínimo de 6,00. No efluente, foi obtida uma média de $(8,16 \pm 0,21)$, com valor máximo de 8,60 e mínimo de 7,90. A introdução do PCP em pH elevado no afluente, devido à presença de $\mathrm{NaOH}$ na solução estoque, aparentou não ter interferido nos valores de alcalinidade e $\mathrm{pH}$. Em comparação ao volume de efluente preparado diariamente, a pequena quantidade de solução estoque acrescentada foi insignificante para provocar qualquer modificação nestes parâmetros, tanto que em nenhum momento foi cogitada qualquer correção do $\mathrm{pH}$.

A Figura 5.53 mostra os resultados obtidos para a concentração afluente de ácidos voláteis, já que o método de cromatografia não detectou ácidos voláteis no efluente do reator, para este período.

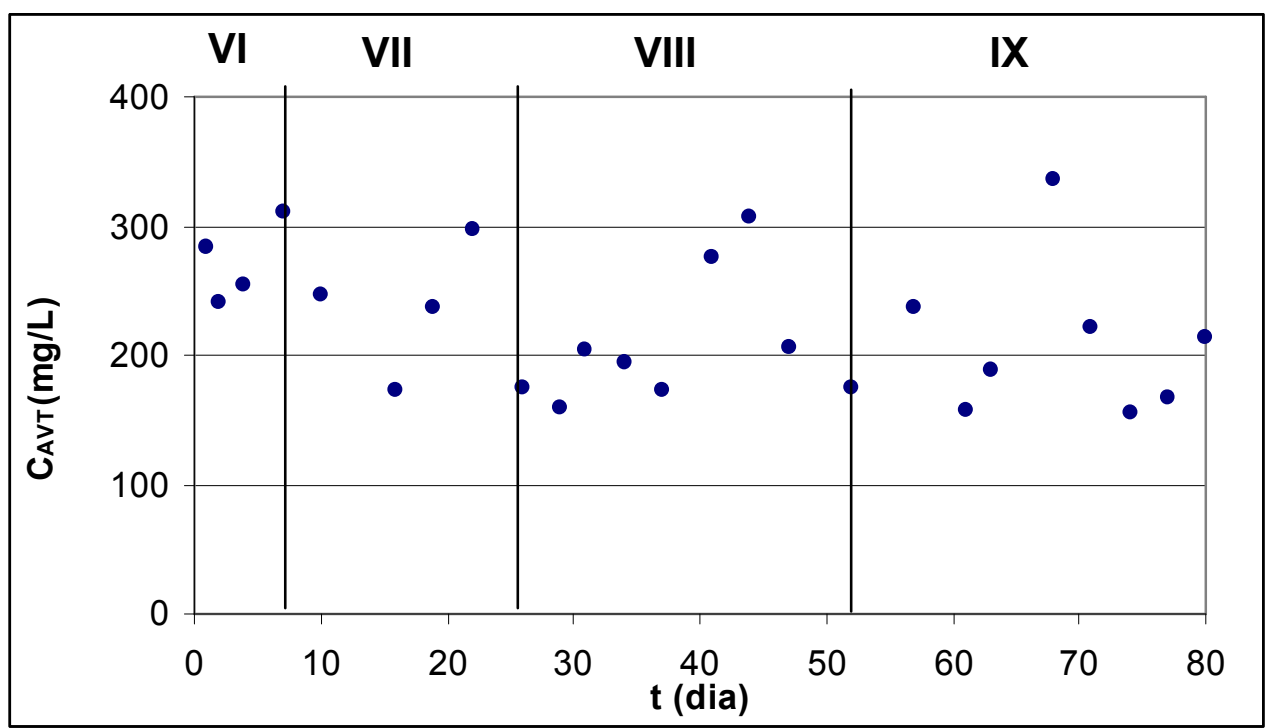

Figura 5.53 - Variação temporal da concentração afluente de ácidos voláteis no RALF A tratando efluente sintético com PCP. 
A Figura 5.54 mostra as concentrações afluentes isoladas de cada ácido volátil encontrado no afluente. Além do ácido acético e do propiônico, algumas vezes o ácido butírico foi detectado também neste período de operação. No que diz respeito aos ácidos voláteis, as concentrações mantiveram o padrão da última fase sem PCP.

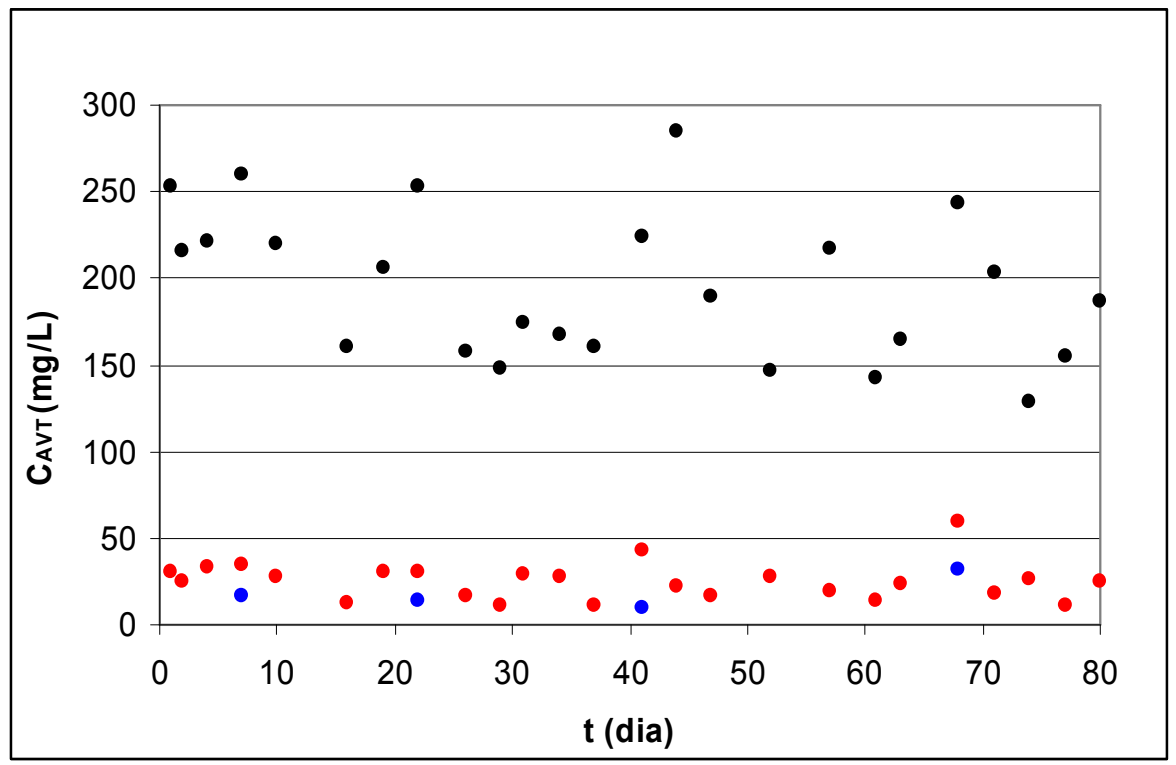

Figura 5.54 - Variação temporal da concentração afluente de cada ácido volátil do RALF tratando efluente sintético com PCP. (•) ácido acético e (•) ácido propiônico (•) ácido butírico.

Todos os parâmetros de monitoramento do reator A que foram descritos até este momento, ou seja, a remoção de matéria orgânica (em termos de DQO), a alcalinidade, o pH e a concentração de ácidos voláteis, demonstraram que o sistema se manteve estável nas condições operacionais aplicadas e que essa estabilidade não foi alterada com a presença de PCP até a concentração de $6 \mathrm{mg} / \mathrm{L}$. Em virtude de os resultados com PCP terem sido similares aos que foram obtidos no período de funcionamento do reator A sem PCP, julgou-se desnecessário se estender em observações que já haviam sido feitas, optandose então por direcionar o enfoque na discussão da remoção de PCP. Semelhante ao procedimento que foi adotado na apresentação dos resultados relacionados com a fluidodinâmica, os resultados obtidos com o desempenho na remoção de PCP serão inicialmente apresentados, e discussões e análises mais aprofundadas serão inseridas em um item posterior. 
Os dados obtidos para desempenho do reator, em termos de concentração de PCP ( $\left.\mathrm{C}_{\mathrm{PCP}}\right)$ no afluente e no efluente e eficiência de remoção de PCP $\left(E_{P C P}\right)$ são apresentados respectivamente nas Figuras 5.55 e 5.56.

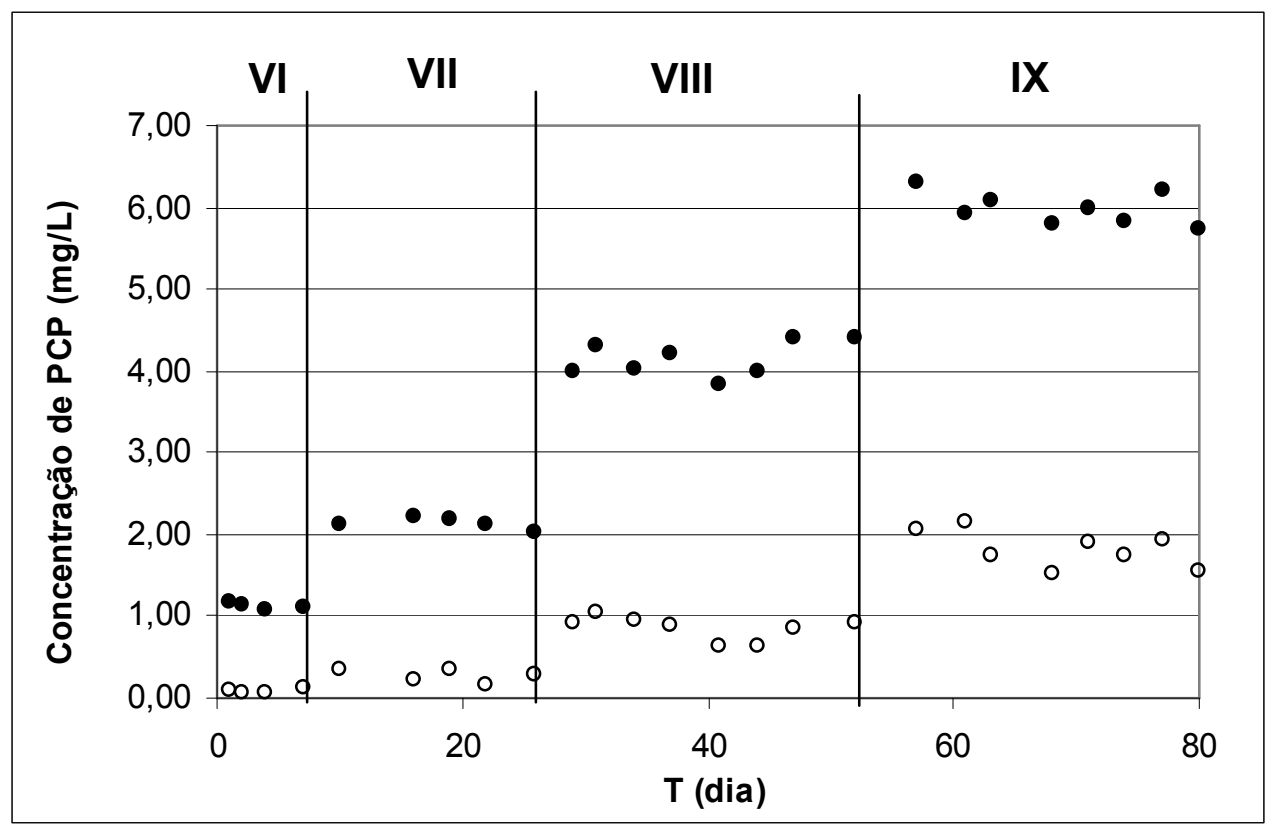

Figura 5.55 - Variação temporal da concentração de PCP $\left(C_{P C P}\right)$ no RALF

A.

(•) $C_{P C P}$ afluente (o) $C_{P C P}$ efluente.

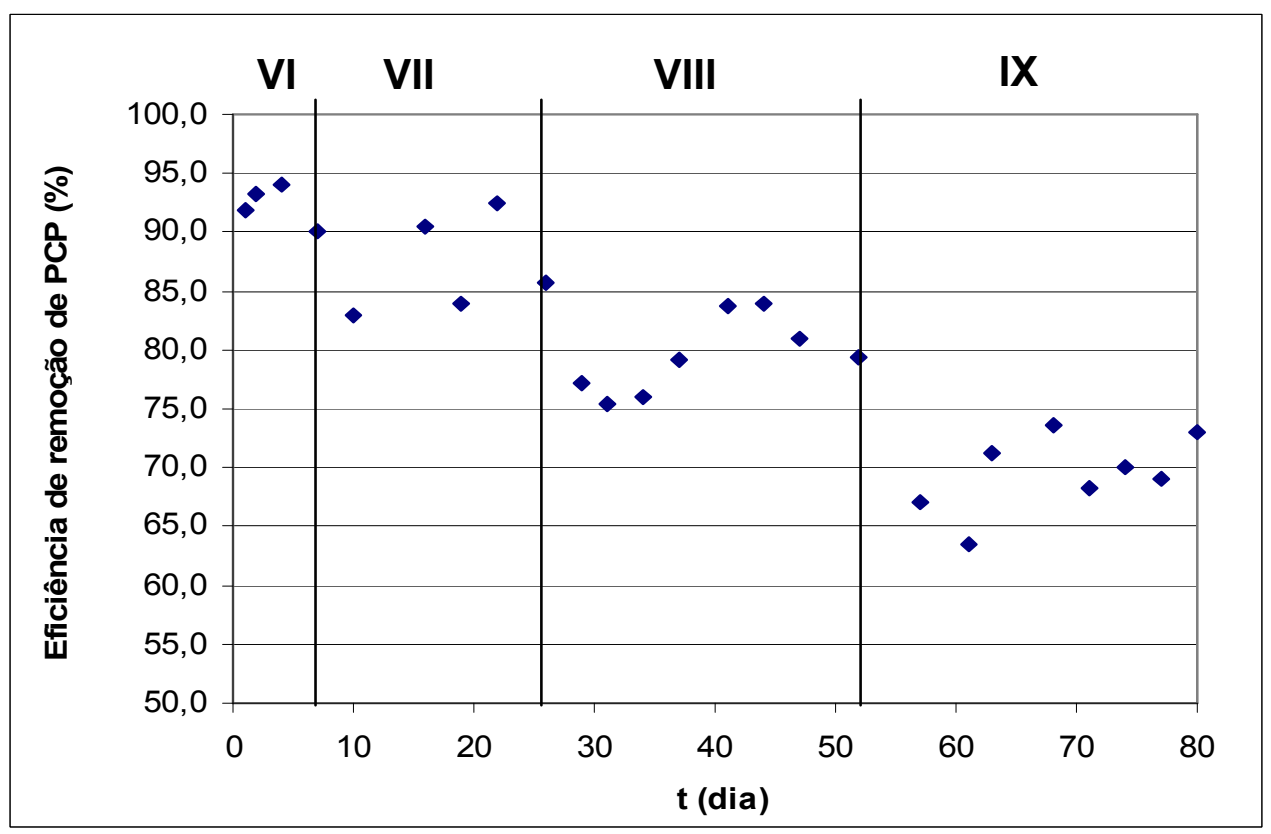

Figura 5.56 - Variação temporal da eficiência de remoção de PCP no RALF A. 
As Tabelas 5.20 e 5.21 mostram, respectivamente, para cada fase do período com PCP, alguns parâmetros estatísticos (média, desvio padrão, valor máximo e valor mínimo) obtidos para as concentrações de PCP (afluente e efluente) e para a eficiência de remoção de PCP.

Tabela 5.20 - Parâmetros estatísticos obtidos para as concentrações de DQO (afluente e efluente) nas 5 fases.

\begin{tabular}{c|cccc|cccc}
\hline \multirow{2}{*}{ FASE } & \multicolumn{4}{|c|}{$\mathbf{C}_{\mathrm{PCP}}$ afluente (mg/L) } & \multicolumn{4}{c}{$\mathbf{C}_{\mathrm{PCP}}$ efluente (mg/L) } \\
\cline { 2 - 9 } & média & DP & máximo & mínimo & média & DP & máximo & mínimo \\
\hline VI & 1,14 & 0,04 & 1,19 & 1,09 & 0,09 & 0,02 & 0,11 & 0,07 \\
VII & 2,13 & 0,07 & 2,21 & 2,03 & 0,27 & 0,09 & 0,36 & 0,16 \\
VIII & 4,15 & 0,21 & 4,41 & 3,84 & 0,85 & 0,15 & 1,06 & 0,63 \\
IX & 5,98 & 0,20 & 6,31 & 5,74 & 1,83 & 0,23 & 2,17 & 1,53 \\
\hline
\end{tabular}

Tabela 5.21 - Parâmetros estatísticos obtidos para as eficiências de remoção de PCP nas 4 fases.

\begin{tabular}{c|cccc}
\hline \multirow{2}{*}{ FASE } & \multicolumn{4}{|c}{$\mathrm{E}_{\mathrm{PCP}}(\mathbf{\%})$} \\
\cline { 2 - 5 } & média & DP & máximo & mínimo \\
\hline VI & 92,3 & 1,7 & 94,0 & 90,1 \\
VII & 87,1 & 4,2 & 92,5 & 82,9 \\
VIII & 79,5 & 3,3 & 84,0 & 75,4 \\
IX & 69,5 & 3,3 & 73,7 & 63,5 \\
\hline
\end{tabular}

Na fase VI de funcionamento do reator $A$, foi aplicada no afluente uma concentração média de $(1,14 \pm 0,04) \mathrm{mg} / \mathrm{L}$ de PCP, com valor máximo de 1,19 $\mathrm{mg} / \mathrm{L}$ e mínimo de 1,09 mg/L, obtendo-se uma concentração média no efluente de $(0,09 \pm 0,02)$, com valor máximo de $0,11 \mathrm{mg} / \mathrm{L}$ e mínimo de $0,07 \mathrm{mg} / \mathrm{L}$. $A$ eficiência média da fase VI foi de 92,3\%, com valor máximo de 94,0\% e mínimo de $90,1 \%$. Na fase VII, a concentração de PCP na entrada foi aumentada para $(2,13 \pm 0,07) \mathrm{mg} / \mathrm{L}$, com valor máximo de 2,21 mg/L e mínimo de 2,03 mg/L. No efluente, foi verificada uma concentração média de PCP de $(0,27 \pm 0,09) \mathrm{mg} / \mathrm{L}$, com valor máximo de 0,36 mg/L e mínimo de 0,16 mg/L. A eficiência média de remoção de PCP na fase VII foi de $(87,1 \pm 4,2) \mathrm{mg} / \mathrm{L}$. Na fase VIII a concentração média de PCP afluente foi de $(4,15 \pm 0,21) \mathrm{mg} / \mathrm{L}$, com valor 
máximo de 4,41 mg/L e mínimo de 3,84 mg/L. A concentração média efluente foi de $(0,85 \pm 0,15) \mathrm{mg} / \mathrm{L}$, com valor máximo de $1,06 \mathrm{mg} / \mathrm{L}$ e mínimo de 0,63 mg/L. A eficiência média determinada para esta fase foi de $(79,5 \pm 3,3) \%$, com eficiência máxima de $84,0 \%$ e mínima de 75,4\%. A última fase de funcionamento do reator teve como concentração média de PCP no afluente o valor de $(5,98 \pm 0,20) \mathrm{mg} / \mathrm{L}$, com concentração máxima de 6,31 mg/L e mínima

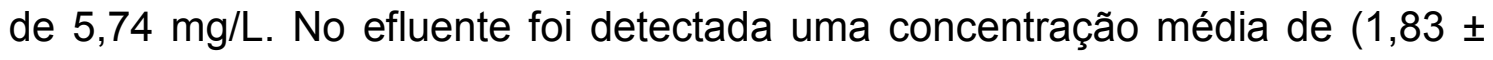
$0,23) \mathrm{mg} / \mathrm{L}$, com valor máximo de $2,17 \mathrm{mg} / \mathrm{L}$ e mínimo de $1,53 \mathrm{mg} / \mathrm{L}$. A eficiência de remoção média foi de $(69,5 \pm 3,3) \%$, com valor máximo de $73,7 \%$ e mínimo de 63,5\%.

Nota-se pela análise dos resultados (Tabela 5.20) que mesmo com as grandes diluições que foram feitas a partir de uma solução estoque de $7 \mathrm{~g} / \mathrm{L}$, foram introduzidas concentrações bem próximas às previamente estipuladas, indicando que o método de cromatografia utilizado para determinação das concentrações de PCP foi apropriado.

As concentrações dos compostos intermediários detectados no efluente são apresentadas na Figura 5.57.

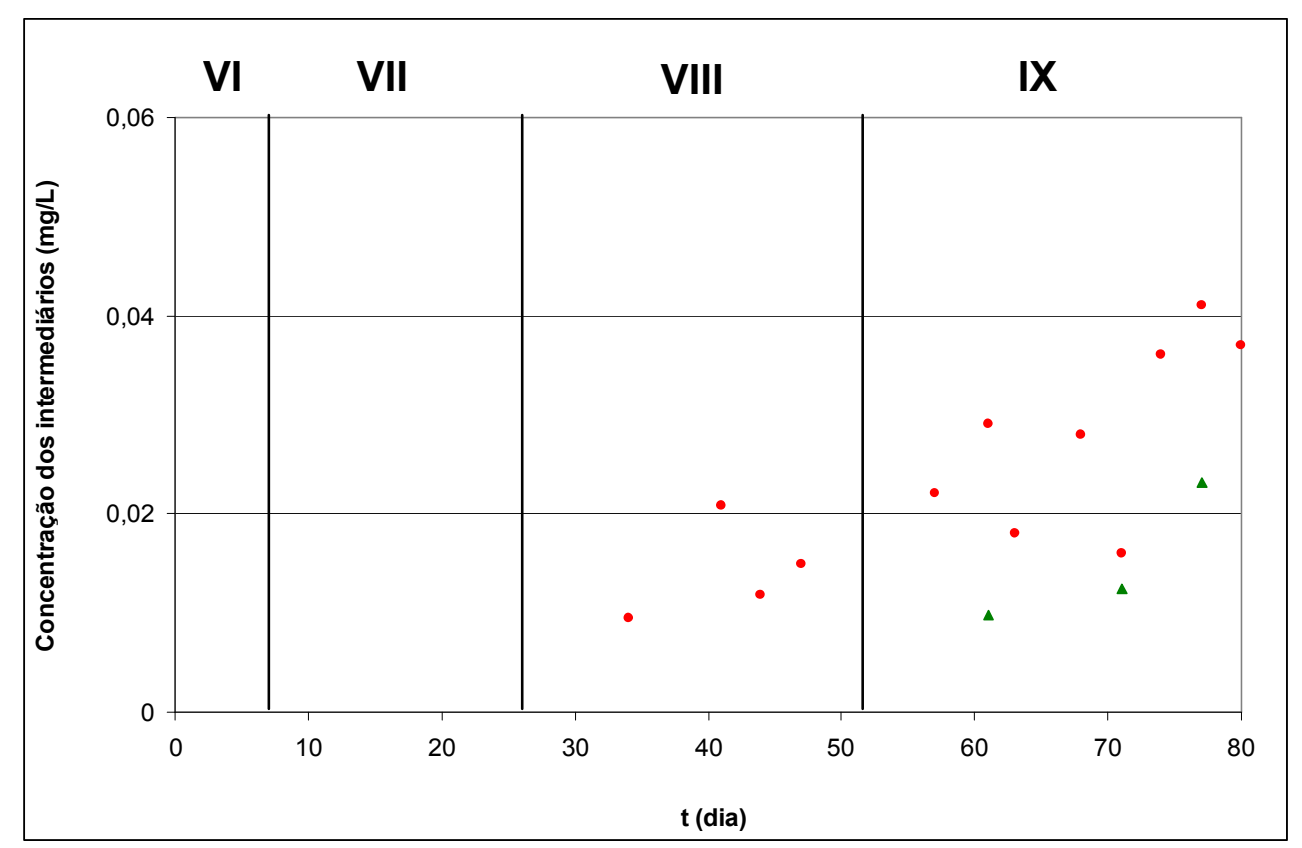

Figura 5.57 - Variação temporal da concentração de clorofenóis intermediários no efluente do RALF $A$.

(•) TCP efluente ( $\triangle$ ) DCP efluente 
Durante os primeiros dias de operação com o PCP, foram obtidos pequenos picos nos tempos de resposta de alguns dos intermediários descritos na Tabela .4.4, demonstrando que a presença destes compostos no efluente ocorreu desde o começo da operação do reator A com PCP. Entretanto, esses picos, quando convertidos para concentrações, resultavam em valores muito pequenos, menores que a concentração mínima padronizada (2,5 $\mu \mathrm{g} / \mathrm{L})$. Apenas a partir do $30^{\circ}$ dia foram determinadas concentrações de triclorofenóis (TCP) no efluente do reator e os diclorofenóis (DCP) foram determinados a partir do 60을.

Sob este aspecto específico, Khodadoust et al. (1997) obteve resultados semelhantes, como mostrou a Figura 3.8 da revisão da literatura. No referido trabalho, apesar de ter sido introduzido no sistema a partir do $44^{\circ}$ dia de operação de um RALF, o PCP foi determinado no efluente apenas a partir do $100^{\circ}$ dia, e pequenas concentrações de TCP's e DCP's foram determinadas apenas por volta do $140^{\circ}$ dia de operação.

O aparecimento de compostos intermediários depois de um certo período de operação e o aumento da concentração destes compostos ao longo do tempo possivelmente estão relacionados com a própria adaptação do sistema. Damianovic (1997), que submeteu o lodo de inóculo a uma adaptação prévia ao $\mathrm{PCP}$, determinou compostos intermediários desde o início da operação do RAHLF. A autora também detectou no efluente os intermediários TCP e DCP. Além disso, as concentrações de tetraclorofenóis (TeCP) foram estimadas, partindo-se da hipótese de que 55\% do PCP recuperado era convertido a TeCP's. Baraldi (2001) relata remoção total de PCP e, no que diz respeito aos intermediários, a autora acrescenta que estiveram presentes em quantidades "traço" indeterminadas. Esse fenômeno não foi encontrado em outra referência.

Neste trabalho nenhum intermediário foi determinado através de estimativas. É conveniente salientar que cinco compostos intermediários foram padronizados (Tabela 4.4), ou seja, apenas uma parcela dos intermediários possíveis no efluente foi quantificada. Nos resultados de cromatografia, inclusive, foram verificados vários picos que não puderam ser convertidos em concentrações, justamente por não estarem padronizados. 
Além de depender do nível de adaptação do sistema, a quantidade (e variedade) dos compostos intermediários também está relacionada com muitos fatores operacionais, dentre eles o tempo de detenção hidráulica aplicado. TDH mais elevados possibilitam uma melhor adaptação do sistema, em fases iniciais de operação, e também permitem que ocorram mais reações de desalogenação. A presença de monoclorofenóis (MCP's) no efluente, por exemplo, implica que várias desalogenações tenham ocorrido, a partir do PCP. Pelo mesmo raciocínio, a aplicação de TDH mais reduzidos possivelmente dificulta sucessivos processos de desalogenação.

\subsubsection{DISCUSSÃO DOS RESULTADOS}

A eficiência média do reator $A$ na remoção de PCP para as concentrações utilizadas ficou entre $92 \%$ e $70 \%$. Os resultados indicam uma queda na eficiência de remoção de PCP principalmente quando foram aplicadas concentrações afluentes de $4 \mathrm{mg} / \mathrm{L}$ e $6 \mathrm{mg} / \mathrm{L}$. A análise do problema, entretanto, não deve se concentrar exclusivamente em termos da eficiência de remoção de $\mathrm{PCP}$, pois este parâmetro está intimamente relacionado às condições operacionais que foram aplicadas. Essa característica, inclusive, dificulta que sejam feitas comparações aprofundadas com a literatura referente ao tema, pois cada trabalho atribui condições de funcionamento muito particulares.

Um aspecto comum, entretanto, encontrado nos trabalhos envolvendo reatores anaeróbios de leito fluidificado no tratamento de substâncias tóxicas foi o elevado tempo de operação, totalizando muitas vezes até mais de 1000 dias (Koran et al., 2001; Wilson et al., 1998). Esse fato mostra que a "especialização" da biomassa é uma das características principais envolvidas nos processos. Fazendo uma analogia com um processo industrial, a qualidade do produto certamente dependerá de muitos fatores, mas, sobretudo da capacidade e especialização da mão-de-obra. No caso dos reatores, essa adaptação pode ser alcançada através de longos tempos de operação, através do contato prévio, ou ainda de técnicas microbiológicas (como as de enriquecimento da biomassa) para potencializar a atividade biológica. 
Os reatores biológicos em escala industrial certamente irão operar em conjunto com outras unidades, muitas vezes fazendo o papel de prétratamento. Portanto, o reator $\mathrm{A}$ apresentou um desempenho satisfatório no cumprimento do seu objetivo principal, ou seja, o de ser uma unidade de prétratamento de um efluente contendo substância tóxica.

Foi possível ainda verificar que condições operacionais menos ideais podem ser aplicadas, tais como o aumento da escala dos reatores, restrições no número de fontes de carbono e na quantidade de matéria orgânica, e ainda menores tempos de detenção hidráulica. Medidas simples como a introdução do PCP em incrementos menores, o aumento do TDH e do tempo de operação de cada fase poderiam até ter proporcionado resultados melhores, mas a proposta era justamente a de situar mais uma referência na linha imaginária de possibilidades que foi descrita na introdução deste trabalho. Essa linha de eventos vai desde a remoção total de PCP sob condições extremamente favoráveis até uma remoção nula.

Os trabalhos futuros devem, aliados aos aspectos fluidodinâmicos, desenvolver processos que aumentem a capacitação microbiológica dos reatores. Esse trabalho, como qualquer outro na área de saneamento, não teve pretensões de oferecer uma metodologia "fechada", mas sim uma pequena contribuição ao processo de otimização dos reatores anaeróbios, principalmente os de leito fluidificado. Pelos próprios fundamentos da ciência e da tecnologia, a otimização será sempre um objetivo a ser alcançado. 


\section{CONCLUSÕES E SUGESTÕES}

As principais conclusões deste trabalho, referentes a todas as investigações que foram feitas, são as seguintes:

- dentre os materiais suporte avaliados, o basalto apresentou resultados inferiores aos outros materiais, o que não o credenciou como um bom meio suporte para o reator anaeróbio de leito fluidificado. A alumina tem um ótimo potencial para se tornar um meio suporte de reatores biológicos. Sua durabilidade e forma geométrica bem definida são grandes atrativos. Com essas vantagens, aliadas à fabricação de partículas um pouco mais leves e com poros maiores (se possível), sua utilização poderá trazer resultados tão bons quanto os obtidos com carvão;

- o carvão ativado ainda é um dos melhores materiais para ser utilizado em processos biológicos, principalmente em reatores de leito fluidificado, porque o emprego deste material consegue aliar tanto bons resultados físicos, como biológicos;

- as isotermas de adsorção de Langmuir, para avaliar a adsorção de PCP no carvão ativado, se ajustaram melhor aos pontos experimentais obtidos. Os resultados em ensaios de batelada indicaram que a presença de matéria orgânica reduziu em cerca de $9 \%$ a adsorção do PCP, demonstrando uma competitividade pelos sítios ativos;

- a adsorção e a degradação biológica são processos que acontecem em escalas de tempo distintas. No caso da adsorção, constatou-se que no máximo em 12 horas era atingida a concentração de equilíbrio. Assim, em experimentos biológicos superiores a esse tempo, a remoção do PCP deverá ocorrer predominantemente por atividade biológica;

- a imobilização de biomassa tornou as biopartículas mais densas em relação às partículas inertes, aumentando em $5 \%$ o valor da velocidade mínima de fluidificação. Esse fato também foi confirmado posteriormente em todos os outros parâmetros analisados, tais como a porosidade, a expansão do leito e a velocidade terminal da partícula; 
- na análise fluidodinâmica são obtidas informações importantes do comportamento operacional dos reatores, e sempre que possível ela deveria preceder a fase biológica das pesquisas;

- o reator apresentou um comportamento satisfatório no período de operação sem PCP. A eficiência média de remoção de DQO ficou quase sempre superior a $90 \%$ (com exceção da fase II) e os outros parâmetros de monitoramento de desempenho apresentaram valores típicos, indicando estabilidade no processo;

- o aumento no volume de reação, através do acréscimo de carvão ativado no leito, aumentando a altura estática de 40 para $60 \mathrm{~cm}$, foi um fator determinante para a melhora do desempenho do RALF e também resolveu o problema de imobilização de biomassa nas paredes;

- a etapa de funcionamento do reator A sem O PCP, programada inicialmente para ser uma etapa "transitória", ou seja, apenas de preparação do reator para a introdução do $\mathrm{PCP}$, acabou revelando aspectos muito interessantes que ainda necessitam de maiores investigações, como a influência da variação do volume de reação no desempenho do reator anaeróbio de leito fluidificado;

- a presença de PCP no sistema, nas concentrações utilizadas, não alterou a qualidade da biomassa presente, e nem os parâmetros de monitoramento de desempenho, como $\mathrm{DQO}$, alcalinidade, $\mathrm{pH}$ e ácidos voláteis, que foram similares aos encontrados na fase $\mathrm{V}$, a última fase operacional do reator $\mathrm{A}$ ainda sem o PCP, e

- mesmo sob condições menos idealizadas, foi observado um desempenho satisfatório do reator $A$ na remoção do composto tóxico pentaclorofenol. Em concentrações variando de 1 a $6 \mathrm{mg} / \mathrm{L}$, foram observadas eficiências médias de remoção de $93 \%$ e $70 \%$, respectivamente.

Conclui-se finalmente que o trabalho cumpriu o objetivo proposto, desenvolvendo e aplicando um conjunto de metodologias que leva em conta o fato de que o processo de tratamento do PCP em um leito fluidificado é um processo físico-químico e biológico. Crê-se que com esse trabalho de natureza 
essencialmente experimental, contribui-se com mais uma referência visando, em etapas posteriores, a modelagem, a simulação, a otimização e o controle desse tipo de reator.

Como sugestões para trabalhos futuros, recomenda-se:

- avaliação de materiais suportes alternativos;

- avaliação da influência do volume de reação, do diâmetro da partícula e da temperatura no desempenho dos reatores anaeróbios de leito fluidificado;

- avaliação da influência da biomassa imobilizada e das condições operacionais e experimentais na fluidodinâmica de reatores anaeróbios de leito fluidificado;

- desenvolvimento de técnicas para aumentar a capacitação da biomassa em remover um determinado composto tóxico;

- desenvolvimento de metodologia para determinação da cinética de degradação biológica;

- efetuar uma análise microbiológica em todas as etapas do processo de tratamento;

- desenvolvimento de modelos físico / matemáticos para a simulação do processo;

- aplicar e desenvolver essa metodologia que foi proposta, para outros resíduos. 


\section{REFERÊNCIAS BIBLIOGRÁFICAS}

ALMEIDA, O.P. (1995). Estudo do Efeito de Fronteiras Rigidas Sobre a Velocidade Terminal de Partículas Isométricas. Tese (doutorado), Programa de Eng. Química, COPPE / UFRJ, Rio de Janeiro.

ANGELIDAKI, S.P.; PETERSEN, S.P.; AHRING, B.K. (1990). Effects of lipids on thermophilic anaerobic digestion and reduction of inhibition upon addition of bentonite. Appl. Microbiol. and Biotech., v.33, n.4, p. 469-472.

ANNACHHATRE, A.P.; GHEEWALA, S.H. (1996). Biodegradation of chlorinated phenolic compounds. Biotechnology Advances, v.14, n.1, p.35-56.

ARAÚJJ, J.C. (1995). Acompanhamento da evolução do biofilme e caracterização química e biológica em reator anaeróbio de leito fluidificado alimentado com esgoto sanitário sintético. 158p. Dissertação (mestrado) - Escola de Engenharia de São Carlos, Universidade de São Paulo. São Carlos.

ASIF, M.; IBRAHIM, A.A. (2002). Minimum fluidization velocity and defluidization behavior of binary-solid liquid-fluidized beds. Powder Technology, v.126, n.3, p.241-254.

BARALDI. E.A. (2001). Avaliação da comunidade e atividade microbiana em reator anaeróbio de leito fixo (RAHLF) operado com pentaclorofenol $(P C P)$, através de métodos cromatográficos, exames microscópicos e técnicas moleculares de PCR, ARDRA e slot-blot. $175 \mathrm{p}$. Tese (Doutorado) - Escola de Engenharia de São Carlos, Universidade de São Paulo, São Carlos.

BLAKLEY, B. R. et al. (1998). Effect of pentachlorophenol on immune function. Toxicology, v.125, n. (2-3), p.141-148.

BOLAÑOS ROJAS, M.L. (1996). Estudo comparativo da capacidade de inóculos de diferentes fontes de degradar PCP sob condições anaeróbias. 134 p. Dissertação - Escola de Engenharia de São Carlos, Universidade de São Paulo, São Carlos.

BRIENS, L.A. (1997a). Minimum liquid fluidization velocity in Gás-Liquid-Solid fluidized beds. A/ChE Journal, v.43, n.5, p.1180-1189. 
BRIENS, L.A. (1997b). Minimum liquid fluidization velocity in Gás-Liquid-Solid fluidized beds of low-density particles. Chemical Engineering Science, v.52, n.(21-22), p.4231-4238.

BUFFIÈRE, P.; FONADE, C.; MOLETTA, R. (1998). Mixing and phase hold-ups variations due to gas production in anaerobic fluidized-bed digesters: influence on reactor performance. Biotechnol Bioeng., v.60, n.1, p.36-43.

BUZZINI, A.P. (2000). Tratamento de águas residuárias simuladas de indústrias de pasta celulósica não branqueada e branqueada. 165p. Tese (doutorado) - Escola de Engenharia de São Carlos, Universidade de São Paulo, São Carlos.

CHEN, C.Y.; CHEN, S.D. (2000). Biofilm characteristics in biological denitrification biofilm reactors. Water Science and Technology, v.41, n.4, p 147-154.

CIOLA, R. (1981). Fundamentos da Catálise. Ed. Moderna, São Paulo.

DAMIANOVIC, M.H.R.Z. (1997). Degradação de pentaclorofenol (PCP) em reatores anaeróbios horizontais de leito fixo (RAHLF). 175p. Tese (Doutorado) - Escola de Engenharia de São Carlos, Universidade de São Paulo, São Carlos.

DEL NERY, V. (1987). Utilização de lodo anaeróbio imobilizado em gel no estudo de partida de reatores de fluxo ascendente com manta de lodo. São Carlos. 187p. Dissertação (Mestrado) - Escola de Engenharia de São Carlos, Universidade de São Paulo, São Carlos.

DIEZ-BLANCO; ENCINA, G.P.A.; POLANCO, F.F. (1995). Effects of biofilm growth, gas and liquid velocities on the expansion of an anaerobic fluidized-bed reactor (AFBR). Water Research, v.29, n.7, p.1649-1654.

FAN, L.S. (1996). Summary paper on fluidisation and transport phenomena. Powder Technology, v.88, n.3, p.245 -253.

FLORA, J.R.V. et al. (1994). Anaerobic treatment of a simulated high-strength industrial wastewater containing chlorophenols. Water Enviromental Research, v.66, n.1, p.21-31.

FREIRE, F.B. (2000). Estudo teórico e experimental de um biofilme anaeróbio em um reator elemento de volume alimentado com acetato como substrato único. 122p. Dissertação (mestrado) - Escola de Engenharia de São Carlos, Universidade de São Paulo, São Carlos. 
GARDNER, D.A.; SUIDAN, M.T.; KOBAYASHI, H.A. (1988). Role of GAC activity and particle size during the fluidized-bed anaerobic treatment of refinery sour water stripper bottoms. J. Wat. Pollut. Control Fed., v.60, p.505-513.

GREENPEACE (2002). Crimes ambientais corporativos no Brasil. Relatório do Greenpeace divulgado em <http://www.greenpeace.org.br/>. Acesso em 2003.

GUAGLIANONI, L.G. (1998). A remoção dos compostos organoclorados Tetraclorocatecol e Tetracloroguaiacol contidos em efluentes da indústria de papel e celulose. 103p. Tese (doutorado) - Escola de Engenharia de São Carlos, Universidade de São Paulo, São Carlos.

IDEC (2004). Instituto de defesa do consumidor. Notícia divulgada em 28 de outubro de 2004 em <http://www.idec.org.br/emacao.asp?id=746>. Acesso em nov 2004.

KHODADOUST, A.P. et al. (1997). Anaerobic treatment of PCP in fluidize-bed GAC bioreactors. Water Research, v.31, n.7, p.1776-1786.

KORAN, K.M. et al. (2001). Effectiveness of an anaerobic granular activated carbon fluidized-bed bioreactor to treat soil wash fluids: a proposed strategy for remediating PCP/PAH contaminated soils. Water Research, v.35, n.10, p.2363-2370.

LARIZZATI, S.F. (1997). Avaliação anaerobia do pentaclorofenol por consórcios metanogênicos enriquecidos. 138 p. Dissertação - Escola de Engenharia de São Carlos, Universidade de São Paulo, São Carlos.

LARSEN, S.; HENDRIKSEN, H.V.; AHRING, B.K. (1991). Potential for thermophilic $\left(50^{\circ} \mathrm{C}\right)$ anaerobic dechlorination of pentachlorophenol in different ecosystems. Appl. Environ. Microbiol., v.57, n.7, p.2085-2090.

MACCHI, A. et al. (2001). Dimensional hydrodynamics similitude in three-phase fluidized beds. Chemical Engineering Science, v.56, n.(21-22), p.60396045.

MENDONÇA, N.M. (1999). Caracterização do material suporte e estudo da partida de um reator anaeróbio de leito expandido utilizado no tratamento de esgoto sanitário. 191p. Dissertação (mestrado) - Escola de Engenharia de São Carlos, Universidade de São Paulo. São Carlos. 
MIURA, H.; KAWASE, Y. (1998). Minimum liquid fluidization velocity in twophase fluidized beds with non-Newtonian fluids. Powder Technology, v.97, n.2, p.124-128.

MONTENEGRO, M. A. P. (2001). Avaliação de performance de um reator anaeróbio híbrido $(R A H)$ e da atividade das populações de microrganismos anaeróbios na ausência e na presença de pentaclorofenol (PCP). 222p. Tese - Escola de Engenharia de São Carlos, Universidade de São Paulo, São Carlos.

MORAES et al. (2000). Determinação de ácidos voláteis por cromatografia gasosa em efluentes de reatores anaeróbios tratando resíduos líquidos e sólidos. Anais da VI Oficina e Seminário Latino-americano de digestão anaeróbia, Recife - PE, v.2, p. 235-238.

OLIVEIRA, S. S. (1998). Avaliação do potencial de um lodo anaeróbio termófilo na biodegradação do composto Pentaclorofenol (PCP). 130p. Dissertação (Mestrado) - Escola de Engenharia de São Carlos, Universidade de São Paulo.

ORTEGA et al. (2001). Aplicação de espumas cerâmicas produzidas via "gelcasting" em biorreator para tratamento anaeróbio de águas residuárias. Cerâmica 47 (304), p.199-203.

PFEFFER, J.T.; SUIDAN, M.T. (1989). Continuous processing of toxic organics in a fluidized-bed GAC reactor employing carbon replacement. Biotech. Bioeng., v.33, n.2, p.139-148.

RIBEIRO, R. (2001). Influência do tipo de substrato na dinâmica de formação de um biofilme em matrizes de espuma de poliuretano. 193p. Dissertação (Mestrado) - Escola de Engenharia de São Carlos, Universidade de São Paulo, São Carlos.

RICHARDSON, J.F.; ZAKI, W.N. (1954). Sedimentation and Fluidisation: Part 1. Trans. Instn Chem. Engrs, v.32, p.35-53.

ROSA, J. (1997). Avaliação da atividade metanogênica de efluentes de indústrias de celulose determinada por ensaios de curta duração com salmonella typhimurium - teste de AMES. 215p. Dissertação (Mestrado) Escola de Engenharia de São Carlos, Universidade de São Paulo, São Carlos. 
RUPP, M.T.C. (1996). Utilização de Zeólitas no Tratamento de Efluentes Inorgânicos. Tese (doutorado), Programa de Eng. Química, COPPE I UFRJ, Rio de Janeiro.

RUTHVEN, D.M. (1984). Principles of Adsorption and Adsorption Process. Ed. John Wiley \& Sons, New York, EUA.

SAFONIUK, M. et al. (1999). Use of dimensional similitude for scale-up of hydrodynamics in three-phase fluidized beds. Chemical Engineering Science, v.54, n.21, p.4961-4966.

SANCINETTI, G.P. (2004). Degradação de fenol em reator anaeróbio de leito fluidificado. 210p. Tese (doutorado) - Programa de Pós-Graduação em Engenharia Química, Universidade Federal de São Carlos. São Carlos.

SANTOS, H.R. (2001). Aplicação de coagulantes no afluente de reator anaeróbio de leito expandido alimentado com esgoto sanitário. 129P. Dissertação (mestrado) - Escola de Engenharia de São Carlos, Universidade de São Paulo. São Carlos.

SILVA, A. J. et al. (2002). Sulphate removal from industrial wastewater using a packed-bed anerobic reactor. Memorias del VII Taller y Simposio Latinoamericano Sobre Digestión Anaerobia, v.2, p.47-50.

SILVA, E.L. (1995). Tratamento aeróbio de fenol em reator de leito fluidificado trifásico. 2 vol. Tese (Doutorado) - Escola de Engenharia de São Carlos, Universidade de São Paulo, São Carlos.

SONG, G.H.; BAVARIAN, F.; FAN, L.S. (1989). Hydrodynamics of three-phase fluidized-bed containing cylindrical hydrotreating catalysts. Can. J. Chem. Engng. v.67, p.265-275.

STANDARD METHODS FOR THE EXAMINATION FOR WATER AND WASTEWATER. (1998). American Public Healt Association. (APHA). 17th ed. New York, EUA.

SUIDAN, M.T. et al. (1996). Anaerobic dedchlorination using a fluidized-bed GAC reactor. Water Research, v.30, n.1, p.160-170.

TOMMASO, G. (1999). Estrutura, caracterização e cinética de lodo anaeróbio imobilizado em espuma de poliuretano tratando substrato sintético contendo proteína como única fonte de carbono. 112p. Dissertação (mestrado) - Escola de Engenharia de São Carlos, Universidade de São Paulo. São Carlos. 
TSUNO, H.; KAWAMURA, M.; SOMIYA, I. (1996). Anaerobic degradation of pentachlorophenol (PCP) in biological expanded-bed reactor. Wat. Sci. Tech.trol Fed. v.34, n.(5-6), p.335-344.

VALLECILLO, A.; GARCIA-ENCINA, P.A.; PEÑA, M. (1999). Anaerobic biodegradability and toxicity of chlorophenols. Wat. Sci. Tech., v.40, n.8, p.161-168.

WANG, Y.; SUIDAN, M.T.; RITTMAN, B.E. (1986). Anaerobic treatment of phenol by an expanded bed reactor. J. Wat. Pollut. Control Fed., v.58, p.227-233.

WILSON, G.J. et al. (1998). Anaerobic/Aerobic biodegradation of pentachlorophenol using GAC fluidized-bed reactors: optimization of the empty bed contact time. Wat. Sci. Tech., v.38, n.7, p.9-17.

ZAIAT, M. (1996). Desenvolvimento de Reator Anaeróbio Horizontal de Leito Fixo (RAHLF) para Tratamento de Águas Residuárias. 157p. Tese (Doutorado) - Escola de Engenharia de São Carlos, Universidade de São Paulo. São Carlos.

ZAIAT, M.; CABRAL, A.K.A.; FORESTI, E. (1994). Reator anaeróbio horizontal de leito fixo para tratamento de águas residuárias: concepção e avaliação preliminar de desempenho. Revista Brasileira de Engenharia - Caderno de Engenharia Química, v. 11, n.2, p.33-442.

ZHANG, J.P. et al. (1995). Minimum fluidization velocity of gas-liquid fluidizedbeds. Trans. I. Chem. Engng., v.73, p.347-353.

ZHANG, X.; WIEGEL, J. (1990). Sequential Anaerobic Degradation of 2,4Dichlorophenol in freshwater Sediments. Appl. Environ. Microbiol., v.56, n.4, p.1119-1127.

ZOTIM, F.M.Z. (1985). O efeito de parede em colunas de recheio. 85p. Dissertação (mestrado) - Programa de Pós-Graduação em Engenharia Química, Universidade Federal de São Carlos. São Carlos. 